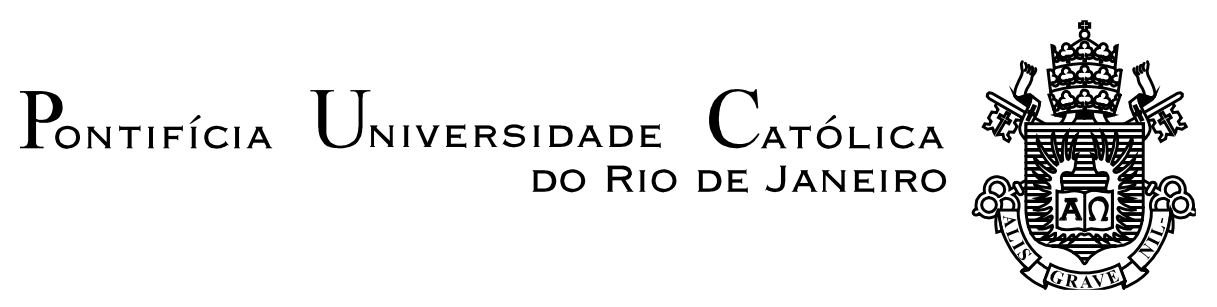

MARIA BEATRIZ DE FARIA CASTANHEIRA RIBEIRO

\title{
IMAGINAR O QUASE-ACONTECIMENTO: Poéticas ameríndias e ocidentais
}

\section{Tese de Doutorado}

Tese apresentada como requisito parcial para obtenção do grau de Doutor pelo Programa de Pósgraduação em Literatura, Cultura e Contemporaneidade, no Departamento de Letras da PUC-Rio.

Orientadora: Profa. Helena Franco Martins 


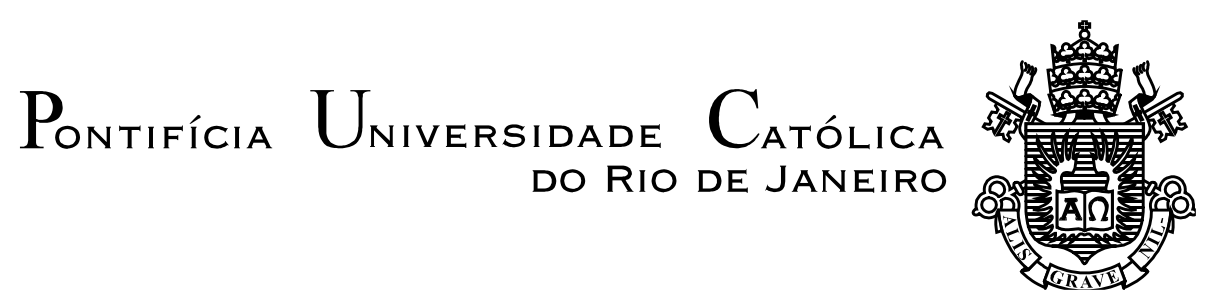

MARIA BEATRIZ DE FARIA CASTANHEIRA RIBEIRO

\section{IMAGINAR O QUASE-ACONTECIMENTO: Poéticas ameríndias e ocidentais}

Tese apresentada como requisito parcial para obtenção do grau de Doutor pelo Programa de PósGraduação em Literatura, Cultura e Contemporaneidade da PUC-Rio. Aprovada pela Comissão Examinadora abaixo.

Profa. Helena Franco Martins

Orientadora

Departamento de Letras - PUC-Rio

Prof. Paulo Fernando Henriques Britto Departamento de Letras - PUC-Rio

Profa. Marília Rothier Cardoso Departamento de Letras - PUC-Rio

Profa. Ana Paula Grillo El-Jaick UFJF

Profa. Lia Duarte Mota UFJF

Rio de Janeiro, 06 de julho de 2020. 
Todos os direitos reservados. É proibida a reprodução total ou parcial do trabalho sem autorização da universidade, da autora e da orientadora.

\section{Maria Beatriz de Faria Castanheira Ribeiro}

Graduou-se em Comunicação Social, habilitação Jornalismo, pela Pontifícia Universidade Católica de Minas Gerais - PUC-Minas, em 1990. Obteve o título de mestre em Letras pelo Programa de Pós-graduação em Literatura, Cultura e Contemporaneidade do Departamento de Letras da PUC-Rio, em 2015. Publicou o romance Avião de papel (Editora Apicuri, 2014). Concluiu em 2013 a Pós-graduação lato sensu "Arte, Literatura e Pensamento Contemporâneo" na PUC-Rio. Áreas de interesse: vínculos entre práticas teóricocríticas e experiências artísticas.

Ficha Catalográfica

Ribeiro, Maria Beatriz de Faria Castanheira

Imaginar o quase-acontecimento: poéticas ameríndias e ocidentais / Maria Beatriz de Faria Castanheira Ribeiro; orientadora: Helena Franco Martins. -2020.

179 f. : il. ; $30 \mathrm{~cm}$

Tese (doutorado) - Pontifícia Universidade Católica do Rio de Janeiro, Departamento de Letras, 2020.

Inclui bibliografia

1. Letras - Teses. 2. Literatura. 3. Perspectivismo. 4. Quase-acontecimento. 5. Devir e xamanismo. 6. Imaginação poética. I. Martins, Helena Franco. II. Pontifícia Universidade Católica do Rio de Janeiro. Departamento de Letras. III. Título.

CDD: 800 
Para Elis e Thales. 


\section{Agradecimentos}

Agradeço ao CNPq e à PUC-Rio pelos auxílios concedidos, sem os quais esta pesquisa não poderia ter sido realizada.

À equipe da secretaria do Departamento de Letras, por toda a ajuda e atenção em todos esses anos.

À minha orientadora Helena Martins, muito especialmente, por me acompanhar há tantos anos na pesquisa, desde o mestrado, por seu olhar sempre meticuloso e sensível e pela carinhosa parceria.

À Marília Rothier Cardoso e à Luiza Leite, por terem participado do exame de qualificação e da banca de defesa. Ao Paulo Henriques Britto e à Ana Paula El-Jack, por também comporem a banca. À Adriana Maciel e à Lia Duarte, por aceitarem ser suplentes e por me apresentarem às Escritas Performáticas. À Marília Rothier, mais uma vez, por cada aula, cada conversa, cada inspiração. 
A Elis e Thales pelo amor e carinho de sempre.

À Elis, de novo, por todas as leituras incríveis e ideias sobre o texto. Ajudou muito.

Ao Thales, de novo, por acompanhar o desenvolvimento da pesquisa, sempre atento, sempre por perto.

Ao Luiz, pelo inestimável apoio.

Ao Victor Squella Rivas, pela importante amizade na reta final do processo.

À Cristiane Fernandes, grande amiga da vida inteira.

O presente trabalho foi realizado com apoio da Coordenação de Aperfeiçoamento de Pessoal de Nível Superior - Brasil (CAPES) - Código de Financiamento 001. 


\section{Resumo}

Ribeiro, Maria Beatriz de Faria Castanheira; Martins, Helena Franco (Orientadora). Imaginar o quase-acontecimento: poéticas ameríndias e ocidentais. Rio de Janeiro, 2020. 179 p. Tese de Doutorado - Departamento de Letras, Pontifícia Universidade Católica do Rio de Janeiro.

Esta tese explora a potência da noção de quase-acontecimento no campo dos estudos literários. Buscando tal noção na esfera do perspectivismo ameríndio, soma-se a investigações contemporâneas que, comprometidas com o imperativo de não presumir vantagem epistemológica nos encontros com os povos indígenas, vêm se interessando em pensar a experiência artística sob o impacto desses encontros. No universo ameríndio, o "quase acontecer" é um evento recorrentemente associado ao trânsito ontológico (viagens aos mundos dos mortos, dos espíritos, dos animais, das coisas etc.), sendo a quasidade um vetor crucial em narrativas míticas e práticas xamânicas. Em contraste com estados de fusão ou anulação, a experiência com a quasidade só pode se manifestar em termos suspensivos. A disposição para habitar, assim em suspensão, zonas de vizinhança entre mundos humanos e não humanos já foi muitas vezes evocada e convocada em conexão com a experiência artística em contextos ditos ocidentais: tomando parte nesse movimento, as reflexões de Deleuze e Guattari são, de modo geral, uma influência importante nos materiais etnofilosóficos aqui em foco, notadamente, os trabalhos de Eduardo Viveiros de Castro, Tania Stolze Lima e Manuela Carneiro da Cunha. Dois aspectos do pensamento da dupla de filósofos franceses importam em especial para este estudo: por um lado, mais teórico, está a insistência no devir feiticeiro do artista; e, por outro lado, mais metodológico, está o caminho que abrem ao construir seu pensamento por meio da invenção de séries heterogêneas de intercessores. Compondo-se de um conjunto eclético de materiais poéticos capazes de perturbar certo modo ocidental de conceber a imaginação, esta tese dedica-se a investigar vínculos possíveis entre imaginação poética e quase acontecimento. Apresentando-se e discutindo-se modos singulares com que poéticas ameríndias e ocidentais mobilizam o quase acontecer, mostra-se que o diálogo com 
práticas interligadas da vida ameríndia abre caminhos férteis para (re)pensar e (re)viver a potência do corpo na imaginação e os vínculos entre práticas teórico-críticas e práticas artísticas. A tese reflete em sua própria escritura este último ponto: os exercícios de leitura aqui realizados fazem transbordar entre si minhas atividades como pesquisadora e como escritora. Por este viés e num recorte que bastará aos interesses deste estudo, tais exercícios respondem à natureza paradoxal das imagens xapiri na narrativa xamânica de David Kopenawa em A queda do céu; à atmosfera míticoritualística de contato dos Ikpeng e dos Yanomami com a morte; e ao desordenamento de corpos que infestam o mito "Pu'iito" - práticas e poéticas ameríndias que ponho em fricção com as seguintes experiências artísticas ocidentais: os livros $O$ imitador de vozes, de Thomas Bernhard e Amada, de Toni Morrison; o poema "Qvasi", de Edimilson de Almeida Pereira; e o conto "O sofredor do ver", de Maura Lopes Cançado.

\section{Palavras-chave}

Literatura; Perspectivismo; Quase-acontecimento; Devir e xamanismo; Arte e corpo; Imaginação poética. 


\section{Abstract}

Ribeiro, Maria Beatriz de Faria Castanheira; Martins, Helena Franco (Advisor). Imagining quasi-events: Western and Amerindian poetics. Rio de Janeiro, 2020. 179 p. Tese de Doutorado - Departamento de Letras, Pontifícia Universidade Católica do Rio de Janeiro.

This thesis explores the potency of the notion of the 'quasi-event' in the field of literary studies. By locating this notion within the sphere of Amerindian perspectivism, it makes use of contemporary investigations that, committed to the imperative of not assuming an epistemological advantage in encounters with indigenous peoples, have been interested in considering the artistic experience under the impact of these encounters. In the Amerindian universe, a 'quasi-event-taken' is an event recurrently associated with ontological transit (i.e., trips to the worlds of the dead, spirits, animals, things etc.), in which quasidade is a crucial vector in mythical narratives and shamanic practices. In contrast to states of fusion and annulment, this experience with quasidade can only manifest itself in suspensive terms. The willingness to inhabit (thus in suspension) neighboring zones between human and non-human worlds has often been evoked and summoned in connection with the artistic experience in so-called Western contexts: taking part in such movement, the reflections of Deleuze and Guattari are, in general, important influences on the ethnophilosophical materials in focus, most notably the works of Eduardo Viveiros de Castro, Tania Stolze Lima and Manuela Carneiro da Cunha. Moreover, two aspects of the French philosophers' thinking are especially relevant to this study: on the one hand, a more theoretical approach is the insistence on the becoming sorcerer of the artist; and, on the other hand, more methodological, is the path they open when constructing their thinking through the invention of a heterogeneous series of intercessors. Composed of an eclectic set of poetic materials capable of disturbing a certain Western way of conceiving the imagination, this thesis investigates possible links between poetic imagination and 'quasi-event'. Hence, introducing and discussing the unique ways in which Amerindian and Western poetics mobilize 'quasi-event-taken', it is shown that the dialogue with 
interconnected practices of Amerindian life clears the path for alternative ways to (re)think and (re)live the potency of the body in the imagination, as well as the links between theoretical-critical and artistic practices. This last matter is reflected in this work's writing process: the reading exercises carried out here make my activities as a researcher and as a writer to overflow with each other. By this bias and in a cut-off that will be enough for the interests of this study, such exercises respond to the paradoxical nature of xapiri images in David Kopenawa's shamanic narrative in A queda do céu; the mythical-ritualistic atmosphere of Ikpeng and Yanomami contact with death; and the disorder of bodies that infest the myth 'Pu'iito' - Amerindian practices and poetics that I put in friction with the following Western artistic experiences: the books $O$ Imitador de Vozes, by Thomas Bernhard and Amada, by Toni Morrison; the poem 'Qvasi', by Edimilson de Almeida Pereira; and the short story 'O sofredor do ver', by Maura Lopes Cançado.

\section{Keywords}

Literature; Perspectivism; Quasi-event; Becoming and shamanism; Art and body; Poetic imagination. 


\section{Sumário}

1. Nota inicial 14

2. O que chamamos de imaginar no que chamamos de 17 Ocidente

2.1. Imagine Platão 17

2.2. Era tudo imaginação 21

2.3. Mas o corpo 25

$\begin{array}{ll}\text { 2.4. Vida de artista, vida de índio } & 47\end{array}$

2.5. Histórias que vale a pena contar, ler, viver 56

2.6. Imagine Platão 59

3. Uma teoria Yanomami do imaginar 64

3.1. Outra imaginação? 64

3.2. Kopenawa em sonho 66

3.2.1. Sobre imaginar o mundo ameríndio 68

3.2.2. A sede móvel do imaginar 70

3.3. Imaginar espíritos $\quad 72$

3.3.1. Sobre o encontro com os xapiri 73

3.4. De volta a isto: imaginar com o corpo 77

3.4.1. Imaginar corpos em caminhos flutuantes 83

3.5. Estado de quasidade 87

3.6. Quasidade fantasmal 91

4. Ler com os índios: quatro exercícios 97

4.1. ...nós, os mortos: Amada, de Toni Morrison 97

4.1.1. Um modo xamânico de morrer 98

4.1.2. Um morrer artístico-performativo 102

4.1.3. Modos de narrar o indescritível 110

4.2. ...nós, as bocas: O imitador de vozes, de Thomas 124 Bernhard 
4.3. ...nós, os fantasmas: "Qvasi", de Edimilson de Almeida Pereira

4.4. ...nós, as pedras: "O sofredor do ver", de Maura Lopes 160 Cançado

5. Nota final

171

6. Referências bibliográficas 
Eu não vi as coisas de que eu falo no papel dos livros nem em peles de imagens. Meu papel está dentro de mim e me foi transmitido pelas palavras dos meus maiores. (...) A força do pó de yãkoana vem das árvores da floresta. (...) Por isso, apenas quem toma yãkoana pode de fato conhecer a floresta. Nossos antigos faziam dançar todos esses espíritos desde o primeiro tempo. Eles nada sabiam do costume dos brancos de desenhar suas palavras. Estes, por sua vez, ignoram tudo das coisas da floresta, pois não são capazes de realmente vêlas. Só sabem dela as linhas de palavras que vêm de sua própria mente.

\author{
David Kopenawa e Bruce Albert. \\ (tradução de Beatriz Perrone-Moisés)
}

Durante muito tempo, costumava deitar-me cedo. Às vezes, mal apagava a vela, meus olhos se fechavam tão depressa que eu nem tinha tempo de pensar: "Adormeço". E, meia hora depois, despertava-me a ideia de que já era tempo de procurar dormir; queria largar o volume que imaginava ter ainda nas mãos $e$ soprar a vela; durante o sono, não havia cessado de refletir sobre o que acabara de ler, mas essas reflexões tinham assumido uma feição um tanto particular; parecia-me que eu era o assunto de que tratava o livro: uma igreja, um quarteto, a rivalidade entre Francisco I e Carlos V.

Marcel Proust (tradução de Mário Quintana) 


\section{1 \\ Nota inicial}

O que acontece quando algo quase acontece?

O que acontece quando algo é imaginado?

Estas são as duas perguntas mais gerais que, tomadas em par, animam as páginas que temos pela frente. Respostas possíveis e lógicas, que tomariam a forma de objeções, seriam as seguintes: quase acontecer é um modo de não acontecer; o imaginado e o acontecido se excluem. Esta pesquisa se interessou por outros caminhos.

O quase acontecer será tomado aqui como um modo de acontecer capaz de pôr em questão compreensões tão disseminadas quanto simplificadas da experiência de imaginar. Já estabelecida como um conceito em certos círculos, a quasidade ${ }^{1}$ perturba o estereótipo da imaginação, aquele convencionado pela cultura, mediante um modelo tradicional de pensamento e de vida - este que, entre outras coisas, insiste em deixar para trás a potência do corpo.

Esta pesquisa atenta para o lugar do corpo nos processos de conhecimento de mundos, investigando os vínculos possíveis entre imaginação poética e quaseacontecimento. A imaginação poética nos permite, de modo intenso, experimentar a quasidade na experiência vital com o mundo. Nos termos da perspectiva deleuziana, uma entre outras que sustentam a relação entre arte e experiências limítrofes, a imaginação poética, concebida como concreta e encarnada, é ocasião de habitar, em estado de suspensão — ou, conforme o caminho seguido aqui, de quase-acontecimento —, zonas de vizinhança entre esferas habitualmente separadas: humano e animal, animado e inanimado, masculino e feminino, molar e molecular, e assim por diante. Trata-se do desejo de surpreender, nessa região, uma indiscernibilidade que inviabiliza a clareza de partições ontológicas tomadas como universais e absolutas em nosso "grego" senso comum.

\footnotetext{
${ }^{1}$ Sobre a noção de quasidade, ver, por exemplo, Viveiros de Castro (2009a) e Nodari (2018). Ao longo da tese, farei uso do termo quase como conceito e como substantivo, onde passarei a dispensar a marcação em itálico.
} 
Essa espécie de trânsito suspensivo para a beira de mundos outros (e dos outros), mobilizando a experiência de imaginar com o corpo, tem sido apontada e explorada como um ponto de conexão entre a arte dita ocidental e algumas poéticas e práticas interligadas da vida indígena, como as narrativas míticas e o xamanismo ${ }^{2}$. Em contextos ameríndios, o xamanismo é, tipicamente, a via para o trânsito entre mundos. Pode ser pensado como um saber experimental que provoca um tipo de pensamento entremeado por sensações e permite conectar campos que tradicionalmente não se relacionam. Esse saber é, em seus aspectos mais radicais, muitas vezes incompreensível para nós, os ditos ocidentais; e costuma mesmo ser tomado como algo culturalmente desprezível.

Nesse nosso modo de vida, em que parece ainda vigorar aquele descompasso entre o apolíneo e o dionisíaco cujas raízes Nietzsche surpreendeu na alvorada da filosofia na Grécia, o mito é visto por muitos como mentira e, nessa esteira, a narrativa xamânica, como mera ficção. Essa maneira de ver marca o modo como rotulamos, ostensiva ou tacitamente, tanto os artistas quanto os índios: mesmo entre os críticos mais ferrenhos desses preconceitos, é insidiosa a propensão de serem ambos, artista e índio, vistos como outros entre nós. Sem reivindicar um lugar externo e invulnerável a essa propensão, esta pesquisa se soma a outras que se interessam justamente pela alteridade aí prometida - interessa-se em tomar os encontros com a arte e com o índio como ocasiões para liberar o outro exilado no mesmo.

Uma vez que podemos pensar que a atuação xamânica tem a ver com a operação de ficcionalizar, no que diz respeito à materialidade literária propriamente dita, o quase acontecer remete a diferentes situações de coexistência de forças e sentidos estrangeiros entre si numa relação. São realidades vividas na prática poética: realidades que não se resolvem, mantendo-se em estado de quasidade - aqui percorreremos algumas dessas instâncias de realidade poética, nas quais acontece, por exemplo, a convivência com a morte que habita nossos corpos em vida, com as vozes alheias que habitam a intimidade de nossas bocas, com os fantasmas que rondam nossa existência, com as pedras que atravessam o caminho de nossas retinas tão fatigadas (já disse o poeta).

\footnotetext{
${ }^{2}$ Alguns exemplos em Lagrou (2008) e em Brasil (2016).
} 
Nesse contexto, experimentar um morrer é então um quase experimentar, falar através do outro ou da presença tácita do outro é um quase falar, fazer circular corpos de palavras em corpos de palavras é deixar-se afetar por quase criaturas, abrir espaço na retina para o olhar de uma pedra é abrir o corpo para um quase delírio. Performances dessa natureza são pano de fundo para um desejo de alteridade que atua na linguagem, a partir de um ancoramento (um corpo situado) paradoxalmente em suspensão intercalada de terror, encanto, angústia, surpresa. Me interesso por fazeres artísticos deflagradores de experiências liminares como essas. Fazeres atravessados por um imaginar com o corpo: cada um levado ao limiar (como sinônimo de véspera). Um quase-acontecer em que formas de vida múltiplas se superpõem intensivamente entre diferentes naturezas ou ontologias. Na beirada desse limite para o corpo, por onde acontece um fluxo constante de linguagens (feitas de palavras ou não), como um jogo entre corpos, surge a possibilidade de sobreposição de vida e de imaginação. É por aí que toda uma pluralidade de sentidos pode ser pensada; onde em cada acontecimento há pedaços vindos de outros acontecimentos.

Atravessado de ponta a ponta por uma atenção à quasidade, o estudo se estrutura em três partes: a primeira explora a vida do verbo "imaginar" no espaço (inquietamente) acomodado sob a palavra "Ocidente"; a segunda busca aprender sem apreender o pensamento sobre o imaginar que se depreende de A queda do céu, do xamã e líder Yanomami Davi Kopenawa; na terceira, com o repertório incorporado nos dois momentos anteriores, põem-se poéticas ameríndias em contágio e fricção com as seguintes experiências artísticas ocidentais: os livros $O$ imitador de vozes, de Thomas Bernhard e Amada, de Toni Morrison; o poema "Qvasi", de Edimilson de Almeida Pereira; e o conto "O sofredor do ver”, de Maura Lopes Cançado. 


\section{2 O que chamamos de imaginar no que chamamos de Ocidente}

2.1. Imagine Platão

Seus pés riscam o chão do barco. Está usando sandálias. Perto dos setenta anos de idade, está sendo conduzido como passageiro rumo ao sudeste da Sicília. Logo estaria em Siracusa para tentar de novo: transformar a tirania ali instalada em realeza constitucional e tornar austera a vida da corte. Conhecia a região graças a outras viagens à terra de Dionísio I, esta que agora se encontrava sob domínio do filho, igualmente tirano, Dionísio II.

A viagem seria a última do total de três visitas que fez ao lugar. Para ele, essas viagens iam na direção de um sonho que acalentava desde muito jovem: o de levar consigo a Siracusa uma maneira de ver que seria como uma aurora que alcançaria toda a Sicília. Uma aurora e, nela, uma herança de conhecimento a ser deixada. Um conhecimento para todo o sempre e pelo qual agora, naquele calor, ele não abria mão de enfiar a cabeça onde ao menos pensava que haveria algo de importante a ser feito. Não tinha a menor intenção de mergulhar num abismo, e Siracusa, em cuja direção erguia os olhos, fazia com que ele caminhasse pelo convés, da popa à proa, passando pelo mastro e suas velas de linho deitadas no chão de madeira, já que remadores da trirreme estavam em ação. Agitado demais, por um momento, mais sereno, interrompia a caminhada e podia ver tudo que se passava ao redor.

Desde o início da interminável tarefa, a influente cidade-estado, com sua fama de riqueza e esbanjamento, pareceu apropriada à aplicação de suas concepções em matéria de lei e de regime político. Por essa época, do ápice, o governante tirano o convencera a retornar. E o convencera com ameaças. Ceder a tal espécie de encorajamento teria sido algo totalmente contrário a sua natureza, mas as chantagens sofridas estavam relacionadas a um grande amigo de muitos anos, Díon, a quem desejava acima de tudo que pudesse, sem maldade e com sabedoria, retornar do exílio 
forçado e ocupar-se da implantação daquela maneira de ver que ele próprio havia transmitido ao amigo.

Ah, talvez ele quisesse ouvir o tirano professar sua admiração pela classe privilegiada de filósofos, talvez quisesse ouvi-lo admitir que gostaria de pertencer a ela. Então quem, por si só, quem, além dele, ninguém melhor afinal para ensinar aquele exercício de pensamento ou aquele modo de vida que por tanto tempo o tirano talvez admirasse em vão. Como não pensava que com isso se exporia inutilmente e tudo era ainda muito pior do que ele pensava, havia decidido compreender a verdade por inteiro e não apenas a farsa de um tirano miserável e mentiroso. Assim ele se preparava. Assim, se fosse de fato seguir viagem, no ponto alto dessa aventura, experimentaria a força perturbadora de um acontecimento que ainda agora seria incapaz de imaginar.

Depois de um período não demasiado curto de empenho na frustrante tentativa de doutrinação filosófica, está de volta a Atenas.

Não teve como evitar uma catástrofe e sobre a Sicília um luto se abateu. O amigo Díon foi assassinado e ele agora está prestes a escrever uma carta que seria também uma esperança para Siracusa. Parentes e aliados do amigo lhe pediram: a cidade-estado precisava de ajuda, em atos e em palavras, para que se garantisse a sobrevivência do legado intelectual e político de Díon. Curvado sobre a mesa, ele pensa: de Díon? Não, a verdade é dona de si mesma e o filósofo apenas...

Esta é uma noite cheia de estrelas e de silêncio. Corre os olhos pelas paredes sombrias e fixa-os no papiro sob a réstia de luz da lamparina de azeite. Os dois olhos fatigados ainda sorriem discretamente para a pena entre os dedos apesar de acumularem certa dose de desgosto. Se tal desgosto ou mesmo ressentimento se anunciam por uma gota de tinta que cai da pena e acende o desejo de rabiscar algumas palavras, dos ombros largos pendem braços doloridos, mãos ossudas e um dedo cuspido de tinta que se volta contra ele, contra sua vontade de escrever: dedo homicida. Tem vontade de parti-lo ao meio com os dentes e uma ânsia de morrer ali mesmo, mas, como alguém que pronuncia a verdade, deve saber que a injustiça é um mal maior que a própria morte. 
Sim, a verdade, como trazer a verdade a uma carta? Muitas vezes tentou. Rabiscou na margem direita... rabiscou no sopé do papiro: Se a palavra escrita não me sai do pensamento de que adianta amaldiçoá-la? Se pelo menos uma carta fosse capaz de escutar uma pergunta, pensou, se pelo menos com ela fosse possível cortar e costurar uma resposta... A importância dos diálogos: sim, com Sócrates e suas amizades, o conhecimento nasce do ir e vir das vozes. Até onde a memória é capaz de alcançar, pode escutá-las com clareza. Ele guarda nos ouvidos as máximas de Sócrates, que ainda hoje determinam o curso de seu dia. Sentado encolhido na cadeira, imagina a cena instrutiva: Sócrates, genial e ousado - consegue ouvi-lo na Ágora, defendendo suas ideias sobre a verdade. Isso sempre agradou. Enquanto segue ouvindo mais e mais, diz a si mesmo sem parar que alguma coisa é preciso fazer. Mas como trazer verdade a uma carta? Certos temas, fosse um deles a verdade, é sempre melhor não escrever sobre essas questões. Ocorre que a palavra, ele diz com frequência, por seu estatuto, que é o de uma coisa sensível - mutável e relativa - parece insuficiente como caminho ao verdadeiro conhecimento.

Conto da minha vida então, continua dizendo a si mesmo, e do que vivi com Dionísio e com Díon: relato o encontro de nossas vozes, sim, porque aquilo fez parte de mim, assim como aqueles que eram próximos e com quem fiz amizade. Isso ele também costuma repetir e nada o fascina mais do que a ideia de que a amizade com Díon havia começado já no primeiro diálogo.

Agora, ainda que num momento bastante incomum, é necessária uma resposta escrita aos parentes e aliados do amigo. Preparando nos mínimos detalhes o relato, põese a escrever, a atenção dividida entre o que realmente importa e as letras que sua mão vai desenhando, como modulação para chegar lá. (... sem amigos e companheiros fiéis, não é possível agir. ...eu seria capaz de executar tudo de bom. ...encontrei tudo cheio de sedição em torno de Dionísio e de calúnias... ele fingia ter bastante necessidade de mim... Pois Dionísio enviou-me, da terceira vez, uma trirreme... $)^{3}$.

Teria sido tolo a ponto de ignorar o futuro terrível de Díon? Não era, pois, de admirar que tivesse sido ao menos confiante em excesso. Como, aliás, sempre

\footnotetext{
${ }^{3}$ PLATÃO. Carta VII. Tradução de José Trindade Santos e Juvino Maia Jr. Rio de Janeiro: Loyola/PUC-Rio, 2008. 325b, 328c, 329c, 329d, 339a.
} 
desaprovara por completo o comportamento de Dionísio. Faltava ao tirano capacidade mental, ainda que, para imposição de força física, tenha sido capaz de publicar um livro sobre assuntos que não dominava e com ideias ouvidas de outros como se fossem suas. Sempre desaprovara tudo isso. Detestava a impetuosidade daqueles que se manifestavam por escrito, de forma amadora e, de todo modo, odiava quando se atreviam a descrever certas realidades impossíveis de ser descritas. Estes tinham por certa a reprovação da parte dele que não precisava agora de uma explicação escrita para verbalizar sua antipatia.

Ah, mas isto importa:

Para cada ser há três elementos que nos permitem conhecê-lo; o quarto é o próprio conhecimento, vindo a ser o quinto a coisa conhecida e que verdadeiramente existe. $O$ primeiro é o nome; o segundo, a definição; o terceiro, a imagem; e o quarto, o conhecimento. ${ }^{4}$

Até o fim da vida, continuaria expondo as limitações do discurso escrito e a impotência da tagarelice em geral. Porque, sem dúvida, o caminho até o saber tem de passar pela convivência gerada pela intimidade. Esta é uma de suas constatações habituais. O melhor era ouvir um diálogo. Não havia ensinamento seu do qual não decorresse a ideia do diálogo como uma possibilidade diante da qual brilhará o conhecimento. E ele se pautava inteiramente pela ideia de que esse brilho se elevará somente à medida que nos voltarmos para um conhecimento rigoroso do mundo. Com inteligência, sabia bem que há como se aproximar daquilo que verdadeiramente existe, mas somente após questionamentos e divergências, mediante muitas tentativas, por assim dizer, quando descartamos e contestamos fórmulas prontas. Ah, esses colóquios amistosos e privados, também isso o fascinava. Eram para ele o que havia de mais elevado. Faziam-no atingir o topo para concluir que, a fim de se obter o conhecimento verdadeiro, para além de palavras e sensações, estas que são inadequadas à expressão do saber, era preciso transformar tais condições aleatórias em pensamento: na alma.

Com a atenção sempre voltada para o essencial, o cheiro enfadonho da tinta ameaça sufocá-lo. Não, não é simples imaginação, ele pensou. Só a figura de Sócrates

\footnotetext{
${ }^{4}$ PlAtão. Carta VII. Tradução de José Trindade Santos e Juvino Maia Jr. Rio de Janeiro: Loyola/PUC-Rio, 2008., 342a..
} 
poderia salvá-lo da amorfia: o pensador subordinava o discurso escrito a uma crítica sistemática. E ele esteve presente todas as vezes que Sócrates não poupou esforços em afirmar que a palavra sobre um rolo de papiro não era nada além de uma imagem do discurso escrito na alma.

Mas nesse instante da escrita levada já muito adiante, ele não sabe o que fazer. E por isso mesmo especula como trazer a mais elevada das questões a uma carta. Sussurrando palavras soltas, larga a pena e embrenha os braços na túnica, sob o manto.

Nada mais se movia. Era madrugada.

\section{2.}

\section{Era tudo imaginação}

A narrativa que abre este capítulo foi escrita a partir da Sétima Carta, de Platão. A carta é conhecida, entre outras coisas, por conter, resumidas, as ideias do filósofo grego sobre as relações entre o conhecimento verdadeiro, a palavra (falada e escrita), a imagem e as artes miméticas. Como se estivesse percorrendo uma linha, arrancando da boca de Platão algumas palavras que poderiam ter sido pronunciadas entre 354-353 a. C, encontro, no ano de 2020, a cena de uma imagem do imaginar que se dissemina no Ocidente $^{5}$. Uma coisa que me chama a atenção nesse modo arraigado de conceber o imaginar é justamente o seu elevado grau de disseminação: ele está presente em nosso modo de vida, vindo mesmo a constituir, em versão aguada, uma espécie de senso comum.

Penso que o imperativo Imagine Platão tende a disparar respostas que dão sinal do alcance dessa nossa forma normal de ver o imaginar. É uma forma silenciosa e silenciosamente incisiva. Quando escrevo "imagine Platão" - e poderia incluir aqui imagine uma girafa, imagine um governo democrático, imagine um circo — você e eu, nós, os ditos ocidentais, tendemos a compreender esse convite/provocação como a demanda de um esforço mental. Isto é, é comum imaginarmos o imaginar como algo que acontece na cabeça, com ou sem imagens.

\footnotetext{
${ }^{5}$ A referência àquilo "que chamamos de Ocidente" no título deste capítulo pretende sinalizar um cuidado com este termo - "Ocidente"- extremamente problemático. Um pouco mais sobre isso adiante.
} 
Penso, por outro lado, em possíveis reações propriamente ao texto que abre esta tese e que vem logo abaixo do subtítulo Imagine Platão. Escrevi esse texto obviamente como um trabalho de imaginação. Sabemos, não é a primeira vez, tampouco será a última, que alguém adota o procedimento narrativo de reunir e inventar, sensível e intelectualmente, traços de um personagem histórico sem compromisso factual. Não é uma estratégia literária nova, mas continua capaz de operar certos desvios de pontos de vista e complicar diferenças, já que sobre ela não é possível impor limites.

No entanto, quando decido deliberadamente abrir uma tese com um texto ficcional do tipo deste que escrevi, algumas prováveis reações a ele dizem também um tanto desse senso comum mencionado acima. Incômodo, dúvida, descrença, desaprovação diante da superfície imaginária da narrativa? Essas possíveis reações indicam o lugar que tendemos atribuir ao imaginar: pois, mesmo nesses tempos de desconstrução, não vai embora com facilidade a percepção de que o raciocínio que afinal se depreende do texto de Platão demandaria ser apresentado de forma sistemática.

Nesse contexto, eu me pergunto: posso, numa tese, inventar uma história para dar a ver ideias de Platão? Posso emular em parte um modo platônico de operação escritural, talvez, transmudando em conto a sua própria dramaturgia dialógica? Posso simular ficticiamente o fluxo de consciência de uma figura histórica que se notabilizou por optar pela indiretividade, por nunca afirmar ou negar em seu próprio nome as posições sustentadas por suas dramatis personae ${ }^{6}$ ? Alguém que, mesmo nessa carta, em que diz excepcionalmente "eu”, encontra formas de manter a indiretividade? Posso, enfim, encurralar Platão no lugar do ilusionista?

Entre nós, essas perguntas se deixam pressionar pela máxima tautológica "uma coisa é uma coisa, outra coisa é outra coisa", da qual derivam outras máximas íntimas e culturalmente vigentes mesmo quando intelectualmente recusadas — corpo é corpo, mente é mente; ficção é ficção, realidade é realidade; imaginação é imaginação, verdade é verdade; texto acadêmico é texto acadêmico, literatura é literatura.

\footnotetext{
${ }^{6}$ De acordo com a descrição feita por Kraut (2017), a despeito do método dialógico adotado por Platão, recusando-se a assumir a primeira pessoa, não se deve perder de vista o fato de que é o próprio filósofo quem fala (não alguma de suas dramatis personae). É ele quem dá voz às vozes de seu próprio pensamento.
} 
Nesse sentido e nisso que chamamos de Ocidente, fazer de Platão personagem de um jogo literário, numa tese de doutorado, poderia ser tomado como um modo (inócuo senão ofensivo) de reduzir e de caricaturar o seu pensamento. Por um lado, como herdeira cultural do platonismo e, por outro, fazendo parte de uma comunidade acadêmica habituada a regressar a essa voz que nos precede, eu poderia capitular diante da previsibilidade de tais críticas.

Mas quero encarar o trabalho imaginativo de escrever os pés de Platão, seus dedos sujos de tinta, seu corpo curvado sobre a mesa como um trabalho de pensamento relevante para a discussão que desejo propor aqui.

As desconfianças que cercam o próprio texto da Sétima Carta são parte dessa atmosfera onde se instanciam essas máximas sobre o imaginar. Em si mesma, a Sétima Carta tem reputação problemática. Quando considerada como documento nos círculos acadêmicos, o primeiro problema que surge é se o seu texto é apócrifo ou se teria mesmo sido escrito por Platão. Podemos considerar a Sétima Carta um documento autobiográfico confiável? Quando respondem afirmativamente a esta hipótese, pesquisadores $^{7}$ apontam na carta alguns elementos típicos do universo de Platão, ou seja, encontram uma harmonia entre o que se lê ali e outras passagens, por exemplo, de A República e Fedro, textos estes de autoria comprovada. Documento confiável ou embuste apócrifo, esta é uma discussão que não está no foco da minha pesquisa.

Neste momento de apresentação da tese, o aspecto que me interessa diz respeito às complexas ideias platônicas que, simplificadas ao longo do tempo, integram a matriz ancestral desse modo disseminado de ver e viver a imaginação. No grande esquema do dualismo platônico, a imaginação estaria condenada a um lugar confinado: o do mundo sensível. Sua visão de mundo sensível, sabemos, é a de um mundo inferior: o pensar com imagens, eikasia, é algo que pode, na melhor das hipóteses, participar como elemento auxiliar da dianoia, o pensamento abstrato, racional e sistemático, este sim capaz de dar acesso ao mundo mais real, o mundo inteligível das formas imutáveis e indestrutíveis.

\footnotetext{
${ }^{7}$ Entre os partidários da autenticidade da Carta VII, encontram-se Ulrich von Wilamowitz-Moellendorff, Paul Friedländer, G. R. Bury e Luc Brisson.
} 
Para participar do trajeto que leva da doxa à episteme, a imaginação, que não pode por si ser metódica, precisa então ser regulada o tempo todo por um propósito $\operatorname{racional}^{8}$. E quanto às imagens e às imaginações artísticas, estas seriam perversões perigosas - presas ao mundo sensível de modo inexorável e, pior, existindo como simulacros ainda mais afastados dos modelos ideais do que as cópias que pretendem representar. Afinal, os modelos estão postos, mas paira sobre nós sempre o risco da maldição de não haver mais modelos a seguir mediante supostos critérios de verdade.

Que diferença isso faz em nossas vidas? Resulta do movimento pensante brevemente evocado aqui não apenas o hoje já tão comentado desmerecimento epistemológico da imaginação, e sobretudo da imaginação artística, mas, o que é talvez o mais importante para o desenvolvimento desta pesquisa: uma percepção desencarnada do imaginar — um imaginar que ocorreria apenas na mente. Essa percepção, tomada como sinal de um impasse existencial, encontra expressão abreviada em uma carta de Henry Miller a Michael Fraenkel no tempo da Segunda Guerra:

A única coisa realmente moribunda é a imaginação do homem, sua capacidade de sonhar uma terra nova, um céu novo, um inferno novo. Estamos sonhando, a maior parte de nós, do pescoço para cima, com o corpo bem amarrado à cadeira elétrica. ${ }^{9}$

Miller afina-se com a tão falada "reversão do platonismo"10 — uma fórmula nietzschiana cuja direção talvez já tivesse sido indicada pelo próprio Platão, entre outras coisas, pelos gestos irônicos que fazem, no interior de seus próprios escritos, o

\footnotetext{
${ }^{8}$ Ao julgar a imaginação não suficientemente disciplinada para fundamentar o conhecimento verdadeiro, Platão a encerra no mundo da irracionalidade: "Logo, não será fora de propósito, observei, admitir que se trata de dois princípios diferentes; um deles com o qual o homem raciocina, poderá ser denominado o princípio racional da alma; o outro, com o que ele ama e tem fome ou sede, e é arrastado por todas as paixões, receberá o qualificativo de irracional e concupiscente, amigo dos mais variados prazeres e satisfações" (PLATÃO, 1996, 439-d, p. 215-216).

${ }^{9}$ MILLER, Henry; FRAENKEL, Michael. The Michael Fraenkel - Henry Miller correspondence called Hamlet. Tradução inédita de Helena Martins e Marcia Schuback. London: Carrefour Press, 1939. p. 57.

${ }^{10}$ Para Deleuze, a intenção da reversão do platonismo em Nietzsche é a de "fazer subir os simulacros [a potência positiva dos simulacros], afirmar seus direitos entre os ícones ou as cópias. O problema não concerne mais à distinção Essência-Aparência, ou Modelo-cópia. Esta distinção opera no mundo da representação; trata-se de introduzir a subversão neste mundo". Tal modo de conceber a reversão do platonismo implica no envolvimento do corpo no processo imaginativo: como expressão de conjuntos de forças, o corpo está em constante movimento e não diz respeito a um modelo. (DELEUZE, 2009, p. 267).
} 
mythos intrometer-se no $\log o s$, a escrita criticar a escrita, a invenção invadir o relato, e assim por diante. ${ }^{11}$ Quando Miller aborda a condição moribunda da imaginação "do pescoço para cima”, ele não se satisfaz com a oposição platônica entre dianoia e eikasia. Ele quer que a imaginação do homem se liberte da cadeira elétrica e assuma a plena potência do corpo, em vez de permanecer agarrada à frágil e enganosa magnitude do pensamento mental. É como se, ironicamente, procurasse nos alertar sobre a invulnerabilidade desencarnada, abstrata e eterna do pensamento lógico e sobre o real puro das formas que ele promete franquear: não se iludam, também aí era tudo imaginação.

Qualquer que seja a força dessa contra-corrente irônica, desse germe da reversão do platonismo no interior do próprio platonismo, nas ocasiões em que dizemos até hoje, no dito Ocidente, a expressão "era tudo imaginação", tal uso tende a contrapor-se platonicamente a uma dimensão do conhecimento verdadeiro, que é supostamente invulnerável aos tumultos do corpo. O uso da expressão cabe ainda a este Platão:

O pior é que, mal conseguimos alguma trégua e nos dispomos a refletir sobre determinado ponto, na mesma hora o corpo intervém para perturbar-nos de mil modos, causando tumulto e inquietude em nossa investigação, até deixar-nos inteiramente incapazes de perceber a verdade. Por outro lado, ensina-nos a experiência que, se quisermos alcançar o conhecimento puro de alguma coisa, teremos de separar-nos do corpo e considerar apenas com a alma como as coisas são em si mesmas. ${ }^{12}$

\section{3. \\ Mas o corpo}

O que o olhar de Platão projeta na nossa direção é, além do reconhecimento de um senso comum que privilegia uma concepção desencarnada da imaginação, a possibilidade de leitura de toda uma tradição que, de dentro do Ocidente, dispôs-se a objetar a essa concepção e a arregimentar forças em busca da plena potência do corpo na imaginação. Reconheceremos essa potência em Nietzsche, como vimos, e, a partir dele, em tantos outros. Uma potência que evoca o modo de um imaginar "livre da

\footnotetext{
11 "Não seria necessário mesmo levar a ironia até ali? E também que tivesse sido Platão o primeiro a indicar esta direção da reversão do platonismo?” (Ibid., p. 262).

${ }^{12}$ PLATÃO, Fédon. Tradução de Carlos Alberto Nunes. Belém: UFPA, 2011. 66d.
} 
cadeira elétrica", se levarmos a sério a provocação de Henry Miller citada anteriormente. Levar a sério Miller, leitor de Nietzsche, é inconformar-se com uma condição de impasse - com um modo de imaginar que nos aprisiona. Levar a sério Miller é também acreditar ser possível um outro modo de fazer as coisas, um outro modo de existir.

Veremos, é sabido, Nietzsche revoltar-se com o modo de pensar no qual fomos treinados sob o regime dialético da metafísica ocidental. Veremos o filósofo inconformar-se em permanecer nessa condição — trancafiado - e dirigir-se aos “sóbrios" exortando-os a reconhecer o seu parentesco íntimo com os "embriagados", bem como a "fantasmagoria" antropocêntrica do real:

\begin{abstract}
Ali, aquela montanha! E aquela nuvem! O que é "real" nelas? Subtraiam-lhes a fantasmagoria e todo o humano acréscimo, caros sóbrios! Sim, se pudessem fazê-lo! Se pudessem olvidar sua procedência, seu passado, sua pré-escola - toda a sua humanidade e animalidade! Não existe "realidade" para nós - e tampouco para vocês, sóbrios -, estamos longe de ser tão diferentes como pensam, e talvez nossa boa vontade em ultrapassar a embriaguez seja tão respeitável quanto sua crença de que são incapazes de embriaguez. ${ }^{13}$
\end{abstract}

São igualmente conhecidas as suas investidas contra a crença obstinada no reino inexorável da lógica, tomada como princípio fundador do conhecimento e da linguagem e como a norma em relação à qual a arte seria o desvio:

A necessidade do ilógico - Entre as coisas que podem levar um pensador ao desespero está o conhecimento de que o ilógico é necessário aos homens e que do ilógico nasce muita coisa boa. Ele se acha tão firmemente alojado nas paixões, na linguagem, na arte, na religião, em tudo o que empresta valor à vida, que não podemos extraí-lo sem danificar irremediavelmente essas belas coisas. Apenas os homens muito ingênuos podem acreditar que a natureza humana pode ser transformada numa natureza puramente lógica; mas, se houvesse graus de aproximação a essa meta, o que não se haveria de perder nesse caminho! Mesmo o homem mais racional precisa, de tempo em tempo, novamente da natureza, isto é, de sua ilógica relação fundamental com todas as coisas. ${ }^{14}$

\footnotetext{
${ }^{13}$ NIETZSCHE, Friedrich. A gaia ciência. Tradução de Paulo César de Souza. São Paulo: Cia das Letras, 2011. p. 95, aforismo 57.

${ }^{14}$ NIETZSCHE, Humano, demasiado humano: um livro para espíritos livres. Tradução de Paulo César de Souza. São Paulo: Companhia das Letras, 2005. p. 38, aforismo 31.
} 
O pensamento em prosa poética que Nietzsche faz respirar em seus escritos implica outras formas de conhecimento como modos de abrir nosso mundo para ampliação de perspectivas inteligíveis e sensíveis (sem estarmos separados do que conhecemos, dado o complexo de relações de forças que nos constituem). Em inúmeras ocasiões, ele critica a compulsão humana de reconhecer a título de conhecer:

Oh, que fácil satisfação a dos homens do conhecimento! (...) Quando encontram nas coisas, sob as coisas, por trás delas, algo que nos é conhecido ou familiar, como a nossa tabuada, a nossa lógica (...) Também os mais cautelosos entre eles acham que ao menos o familiar é mais facilmente cognoscível do que o estranho. ${ }^{15}$

Com Nietzsche, propõem-se novas maneiras de agir: sobretudo como uma promessa de mudança a partir de uma grande destruição do reconhecido, em favor da criação do desconhecido. Desejo de vertigem. Risco de metamorfose. Expressões de determinados conjuntos de forças, os corpos (multiplicidades pensantes-pensadas), ao entrarem na relação com outros corpos, interpretam e são interpretados em função das forças que se apropriam deles em dado momento e que fazem prevalecer certos sentidos.

\begin{abstract}
Somente enquanto criadores! - Eis algo que me exigiu e sempre continua a exigir um grande esforço: compreender que importa muito mais como as coisas se chamam do que aquilo que são. A reputação, o nome e a aparência, o peso e a medida habituais de uma coisa, o modo como é vista - quase sempre uma arbitrariedade e um erro em sua origem, jogados sobre as coisas como uma roupagem totalmente estranha à sua natureza e mesmo à sua pele —, mediante a crença que as pessoas neles tiveram, incrementada de geração em geração, gradualmente se enraizaram e encravaram na coisa, por assim dizer, tornando-se o seu próprio corpo: a aparência inicial termina quase sempre por tornar-se essência e atua como essência! (...) Somente enquanto criadores podemos destruir! - Mas não esqueçamos também isto: basta criar novos nomes, avaliações e probabilidades para, a longo prazo, criar novas "coisas". ${ }^{16}$
\end{abstract}

Trata-se, então, com Nietzsche, de um fazer pensante, criador, que nos dá elementos singulares para pensar além do binômio universalismo-relativismo, como se o pensamento, a dizer a própria vida, não pudesse mais menosprezar o complexo de forças envolvidas na busca pelo conhecimento, bem como os corpos implicados nessa

\footnotetext{
${ }^{15}$ NIETZSCHE, 2011, p. 250, aforismo 355.

${ }^{16}$ Ibid., p. 95, aforismo 58.
} 
busca. Essa imbricação entre pensamento e vida move a crítica nietzschiana à metafísica universalista, sem se deixar reduzir a um relativismo. O fato é que Nietzsche não estava propondo um "vale tudo" generalizado, como talvez, se tomada em avulso, expressões como "basta criar novos nomes" poderiam enganosamente insinuar.

O perspectivismo, incompatível com o aludido binômio, tem uma de suas mais importantes matrizes ocidentais em Nietzsche; e a noção nietzschiana de perspectivismo está ligada à multiplicidade de focos em uma rede de relações que desconvida a oposição hierárquica entre sujeito cognoscente e objeto conhecido:

Tanto quanto a palavra "conhecimento" tem sentido, o mundo é conhecível: mas ele é interpretável de outra maneira, ele não tem nenhum sentido atrás de si, mas sim inúmeros sentidos. "Perspectivismo". // Nossas necessidades são quem interpreta [auslegen] o mundo; nossas pulsões e seus prós e contras. Cada pulsão é uma espécie de ambição despótica [Herrschsucht], cada uma tem a sua perspectiva, perspectiva que a pulsão gostaria de impor como norma para todas as outras pulsões. ${ }^{17}$

Nietzsche desparafusa a oposição universal-relativo ao expressar o mundo como um corpo. Este corpo, ele o expressa como sendo um campo habitado por uma pluralidade de sujeitos cuja potência nutre-se de impulsos os quais mascaram a força criadora da própria vida: o mundo, os homens e os outros seres. Assim o par sujeito/objeto deixa de ser uma oposição simples para estar constantemente se redefinindo, sendo constantemente posto em jogo.

Os gestos criadores de Nietzsche se orientam para o estabelecimento de territórios críticos às grandes ideias, grandes verdades, aos valores humanistas do Ocidente, ao antropomorfismo moderno e ao paradigma cartesiano. São fazeres que desmontam a sabedoria humana como ideal a ser realizado e privilegiam os efeitos oriundos dos encontros entre forças heterogêneas: efeitos das possibilidades imperceptíveis de todas as aparências.

As contaminações aí implicadas entre as categorias do filosófico e do artístico influenciaram muitos, muitos são os fazeres teórico-experimentais que retomam procedimentos nietzschianos, importando principalmente aos interesses desta pesquisa

\footnotetext{
${ }^{17}$ NIETZSCHE, A vontade de poder. Tradução de Marcos Sinesio Pereira Fernandes e Francisco José Dias de Moraes. Rio de Janeiro: Contraponto, 2008. p. 260, aforismo 481.
} 
apontar aqui os casos de Deleuze, Guattari, Nancy, Benjamin. São corpos escriturais abertos a experiências e perspectivas e nos quais vibram contaminações entre modos de pensar e de viver as nossas relações com os outros daquilo que chamamos de "humano".

Críticos ferrenhos do saber representacional, Deleuze e Guattari mostram como, na história do Ocidente, o pensamento deixa de ser uma força capaz de desencadear ações para se transformar em atividade meramente reflexiva e contemplativa. $O$ pensamento se caracteriza assim pela busca de um conhecimento que, como Nietzsche já havia apontado, alça os valores existentes à condição de verdades superiores. De outro lado, enquanto força criadora, o pensar significa criar novas possibilidades de vida, antes inimagináveis.

O empenho em pensar pela multiplicidade e pela diferença, sob a forma de um perspectivismo que se alimenta de Nietzsche e o transforma, chega a um momento forte com Deleuze e em Deleuze e Guattari, em cujos escritos se experimentam fazeres capazes de desestabilizar, de um modo singular, binarismos do pensamento metafísico. Em tensão teórico-inventiva, algumas relações problemáticas presentes no corpo conceitual de, por exemplo, Mil platôs são importantes para esta pesquisa: devir animal, devir-mulher, devir-criança, devir-louco, devir-molecular, devir-feiticeiro. E igualmente importante para nós é registrar que os dois filósofos pensam o conceito de devir, nessas diferentes manifestações, sob a constante intercessão de artistas:

Há devires-animais do homem que não consistem em imitar o cachorro ou o gato, já que o animal e o homem só se encontram no percurso de uma desterritorialização comum, mas dissimétrica. Como os pássaros de Mozart: há um devir-pássaro nessa música, mas tomado em um devir-música do pássaro, os dois formando um único devir, um único bloco, uma evolução a-paralela, de modo algum uma troca, mas "uma confidência sem interlocutor possível", como diz um comentador de Mozart - em suma, uma conversa. ${ }^{18}$

A arte aparece aqui como espaço de tensão teórico-inventiva com a possibilidade de interferir criticamente nos modos de conhecer-dizer-viver-sentir. Em $O$ que é a filosofia?, Deleuze e Guattari abordam os três modos de pensar - o artístico, o

\footnotetext{
${ }^{18}$ DELEUZE, G.; PARNET, C. Diálogos. Tradução de José Gabriel Cunha. Lisboa: Relógio D’água,
} 2004. p. 13. 
filosófico e o científico - como diferentes respostas, não hierarquizadas, ao caos: “[o] que define o pensamento, as três grandes formas do pensamento, a arte, a ciência e a filosofia, é sempre enfrentar o caos, traçar um plano, esboçar um plano sobre o caos"19. Assim vamos construindo nossos edifícios de pensamento nisso que chamamos de Ocidente. Contudo, especialmente importante aqui são as considerações que Deleuze e Guattari fazem sobre o estatuto criador da arte, sua potência afirmativa diante do caos, sendo crucial para nós a sua noção de devir-feiticeiro do artista, conceito que se refere a um estado selvagem através do qual um artista, em gestos e pensamentos, concretamente, emite com a escrita movimentos minoritários de ação insubordinada, intensa, inscrita no campo da magia: "A arte precisamente inventa mentiras que elevam o falso a esse poder afirmativo mais alto, ela faz da vontade de enganar algo que se afirma no poder do falso" ${ }^{20}$. Como o devir relaciona-se a esse modo artístico menor e a esse procedimento menor do artista (de função política), pode-se dizer que tais movimentos alternativos tomam o pensamento como um prisma para encarar impasses impostos pelas variáveis dominantes. Por exemplo, a humana.

Nesse sentido, em preocupação frequente com os outros daquilo que chamamos de humano e de efeito tão concreto quanto invisível, a partir da mobilização de forças tão impensáveis quanto reais, fazeres em devir-feiticeiro nos acenam com a possibilidade de desdomesticação do próprio pensar (uma possibilidade que extrapola a atitude meramente contemplativa racional) e de abalar alguma dimensão irrefletida de nossos próprios modos de vida.: "[é] assim que operamos, nós feiticeiros, não segundo uma ordem lógica, mas segundo compatibilidades e consistências alógicas" ${ }^{21}$.

O foco que proponho é balizado ainda a partir do aspecto de que tal conceitochave - devir-feiticeiro - é uma expressão que Deleuze e Guattari usam em conexão com as escritas de autores como Kafka, Lovecraft, Virginia Woolf, Melville, Henry Miller e tantos outros, em especial na seção que se intitula "Lembranças de um feiticeiro" no quarto volume da edição brasileira de Mil Platôs. Ali, costurando

\footnotetext{
${ }^{19}$ DELEUZE, G.; GUATTARI, F. Percepto, afecto e conceito. In: O que é a filosofia? Tradução de Bento Prado Jr e Alberto Alonso Muñoz. 3. ed. Rio de Janeiro: Editora 34, 2010. p. 233.

${ }^{20}$ DELEUZE, G. Nietzsche e a filosofia. Tradução de Antônio M. Magalhães. Porto: Editora Rés, s/d. p. 155.

${ }^{21}$ DELEUZE, G.; GUATTARI, F. Mil platôs: capitalismo e esquizofrenia. Tradução de Suely Rolnik. v. 4, 2. ed. Rio de Janeiro: Editora 34, 2012. p. 36.
} 
reflexões aparentemente desvinvuladas, os filósofos referem-se aos fazeres de escritores, de que se lembram, num processo de associação metonímica, e escrevem, eles mesmos, como feiticeiros.

É primordialmente à gama multifacetada de devires por que passa o escritor (passagem esta que o esgota) que faz Deleuze associá-lo também a um médico de si próprio e do mundo. Médico de uma frágil saúde irresistível: “[d]o que viu e ouviu, o escritor regressa com os olhos vermelhos, com os tímpanos perfurados" ${ }^{22}$. Quando Deleuze emprega o termo "médico" associado ao artista, está pensando em Nietzsche, que considerava o filósofo-artista como "médico da civilização"23. Tal perspectiva não se deixa contaminar por uma noção de filósofo ou artista como alguém que vai determinar o modo mais correto de vida ou outra qualquer conceitualização domesticadora, mas implica observar a força disruptiva da escrita, entendendo-se força como devir.

É então num devir-feiticeiro que, com o artista, conquistam-se outras visões e audições e chega-se aos seres de sensação reinventados por Melville, Woolf, Faulkner, Tolstói, Tchekhov, Kleist. Para Deleuze e Guattari, a arte não pode ser definida por uma essência, mas como um modo de agenciamento, uma prática que se concretiza numa matéria artístico-pensante. Tal concretização se dá por meio da atuação de um complexo de sensações composto por afectos ("os devires não humanos do homem”) e perceptos ("as paisagens não humanas da natureza"). As forças incorporais desses seres de sensação nos conduzem a um acontecimento alheio ao humano:

(...) os peceptos oceânicos de Melville; os perceptos urbanos, ou especulares em Virginia Woolf. A paisagem vê. Em geral, qual o grande escritor que não soube criar esses seres de sensação que conservam em si a hora de um dia, o grau do calor de um momento (as colinas de Faulkner, a estepe de Tolstói ou a de Tchekhov)? O percepto é a paisagem anterior ao homem, na ausência do homem. Mas em todos estes casos, por que dizer isso, já que a paisagem não é independente das supostas percepções dos personagens, e, por seu intermédio, das percepções e lembranças do autor? E como a cidade poderia ser sem homem ou antes dele, o espelho, sem a velha que nele se reflete, mesmo se ela não se mira nele? É o enigma (frequentemente comentado) de Cézanne: "o homem ausente, mas inteiro na paisagem". Os personagens não podem existir, e o autor só pode criá-los porque eles não percebem, mas entraram na paisagem e fazem eles mesmos parte do

\footnotetext{
${ }^{22}$ DELEUZE, G. Crítica e Clínica. Tradução de Peter Pál Pelbart. 2. edição. São Paulo: Editora 34, 2011, p.14.

${ }^{23}$ DELEUZE; GUATTARI, 2010, p. 136.
} 
composto de sensações. É Ahab que tem as percepções do mar, mas só as tem porque entrou numa relação com Moby Dick que o faz tornar-se baleia, e forma um composto de sensações que não precisa de ninguém mais: Oceano. É Mrs. Dalloway que percebe a cidade, mas porque entrou na cidade, como "uma lâmina através de tudo", e se tornou, ela mesma, imperceptível. Os afectos são precisamente estes devires não humanos do homem, como os perceptos (entre eles, a cidade) são as paisagens não humanas da natureza. "Há um minuto do mundo que passa", não o conservaremos sem "nos transformarmos nele", diz Cézanne. Não estamos no mundo, tornamo-nos com o mundo, nós nos tornamos, contemplando-o. Tudo é visão, devir. Tornamo-nos universo. Devires animal, vegetal, molecular, devir zero. ${ }^{24}$

Visões de uma paisagem que vê com palavras e sons. $\mathrm{O}$ artista pertence ao mundo da feitiçaria nesta dimensão. Como um xamã, na obscuridade, vacilante, à espreita, percebe e rastreia outros modos de imaginar, outras compreensões, outros mundos. E assim estreita o abismo e desloca a distância entre humanos e não humanos, sujeitos e objetos, matérias e sentidos e tantos outros.

Um caso explorado por Deleuze merece menção detida aqui. Trata-se de T. E. Lawrence - do devir-árabe deste britânico múltiplo que operava simultaneamente em frentes distintas. Híbrido de arqueólogo, militar e agente secreto, em 1917, Lawrence torna-se conselheiro logístico da Revolta Árabe contra a ocupação do território pelo Império Turco Otomano e chega a comandar dez mil homens. Participante efetivo da resistência, articula guerrilhas que culminam na tomada de Damasco, em 1918; até tornar-se conselheiro da delegação árabe na Conferência de Paz de Paris, em 1919. Ao papel desempenhado por ele nessa oportunidade, acrescenta-se um outro de igual importância diplomática: entre 1921 e 1922, atua como consultor de assuntos árabes da Divisão do Oriente Médio do Departamento Colonial, sob a direção de Winston Churchill. A partir de 1919, começa a escrever a obra canônica Os sete pilares da sabedoria, publicada em 1926.

Quanto aos recursos expressivos da escrita de Lawrence, interessa a Deleuze um modo singular de erguer blocos de sensações:

${ }^{24}$ DELEUZE; GUATTARI, 2010, p. 199-200. 
Lawrence, um dos maiores paisagistas da literatura. (...) Lawrence possui um deserto íntimo que o impele para os desertos da Arábia, entre os árabes, e que coincide em muitos pontos com as percepções e concepções destes, mas conserva a indomável diferença que as introduz numa Figura secreta inteiramente outra. Lawrence fala árabe, veste-se e vive como árabe, mesmo sob tortura grita em árabe, mas não imita os árabes, jamais abdica de sua diferença, que ele já sente como uma traição. (...) Essa diferença de Lawrence não se deve apenas ao fato de continuar sendo inglês, a serviço da Inglaterra, pois ele trai tanto a Inglaterra quanto a Arábia, num sonho-pesadelo de tudo trair ao mesmo tempo. Mas tampouco se trata da sua diferença pessoal, tanto que a empreitada de Lawrence é uma fria e projetada destruição do eu, levada até o fim. (...) Trata-se de uma disposição subjetiva infinitamente secreta, que não se confunde com um caráter nacional ou pessoal e que o leva para longe de seu país, sob as ruínas do seu eu devastado. ${ }^{25}$

Para Deleuze, "não há problema mais importante que o dessa disposição que arrasta Lawrence e o desata das "cadeias do ser" ${ }^{26}$. Ele acrescenta que se trata

de um profundo desejo, de uma tendência a projetar nas coisas, na realidade, no futuro e até no céu, uma imagem de si mesmo e dos outros suficientemente intensa para que ela viva sua própria vida: imagem sempre retomada, remendada, e que não para de crescer ao longo do caminho até tornar-se fabulosa. ${ }^{27}$

Este talvez seja um ponto-chave da questão do devir-feiticeiro: antes de tudo, trata-se de uma experiência transfronteiriça. Lawrence rompe com formas de expressão do eu, mas conserva sua "indomável diferença" em relação à alteridade. Ao atribuir poder a tal relação, poder de uma imagem de deserto "suficientemente intensa" - imagem cuja força reside no devir -, confere-lhe vida própria. Imagem viva, o deserto acontece no contato de Lawrence com o outro. Deserto que o impele para a Arábia tanto quanto expulsa-o de si mesmo, como se fosse ele, em certa medida, intruso de si e do outro. Nesse sentido, o deserto de Lawrence seria ainda a imagem viva de um intruso na fronteira do eu com o outro. Mas como compreender esse eu e esse outro?

No ensaio filosófico-literário O intruso, referindo-se à experiência do transplante de coração a que foi submetido, Jean-Luc Nancy observa que "o intruso se introduz à força, por surpresa ou astúcia; em todo caso, sem direito ou sem primeiro ter sido

\footnotetext{
${ }^{25}$ DELEUZE, 2011, p.148-150.

${ }^{26}$ Ibid.

${ }^{27}$ Ibid.
} 
admitido" 28 . Trata-se de um contato com o intruso que aconteceria como um choque um encontrão. Nas narrativas testemunhais de acontecimentos impactantes como este, nota-se em geral um esforço empreendido para relatar algo que acontece a um $\mathrm{eu}$, algo determinado pela vivência de uma situação limite. Ao contrário, no texto de Nancy, vale ressaltar o aspecto que extrapola a narrativa pessoal:

No caso do testemunho de Nancy, este teria que lidar com o estranhamento de uma falta de lugar, um desconcerto, uma falta de origem. Deflagrado este estranhamento, o relato evidencia, pouco a pouco, que a falta é um dos elementos constituintes de um si mesmo. O livro de Nancy tenta fazer jus não à morte de um grupo ou de um outro indivíduo, mas à eterna morte de um si mesmo, que na verdade nunca se deu verdadeiramente a si. Pois o estranhamento fundamental do livro diz respeito a um estranhamento identitário, a um estranhamento sem retorno a si. Nesse sentido, a voz que ali se faz presente, também empresta-se, ausente de si, para relatar a sua própria ausência. ${ }^{29}$

Num encontro ou encontrão efetivo com o intruso, com o outro, este deixa de ser o meu outro. Perturbam-se os limites entre o dentro e o fora de um si mesmo. O encontro efetivo supõe superar aquele vício em reconhecer de que falava Nietzsche - a tendência de um si mesmo a sempre "pensar o seu outro: o seu próprio outro"; pois, "ao pensálo como tal, ao reconhecê-lo, perdemo-lo", o que faz com que o outro "retorne sempre ao mesmo". ${ }^{30}$ Sobre isso também fala Deleuze, quando, por exemplo, em "Michel Tournier e o mundo sem outrem", a propósito de Sexta-feira, de Michel Tournier, uma reescrita de Robinson Crusoé, atribui o papel de outrem à expressão de um mundo possível: “[u]m semblante assustado é a expressão de um possível mundo assustador ou de alguma coisa de assustador no mundo que ainda não vejo" ${ }^{\prime 31}$. Deleuze vale-se das aventuras de Robinson em sua ilha para falar dos efeitos de outrem a partir da ausência deste na experiência do naufrágio. Ausência esta que torna o mundo de Robinson espectral e fantasmagórico. Os efeitos de outrem introduzem o não-percebido no que

\footnotetext{
${ }^{28}$ No original: "L'intrus s'introduit de force, par surprise ou par ruse; en tout cas sans droit ni sans avoir été d'abord admis" (NANCY, 2010, p. 11.).

${ }^{29}$ GHETTI, P. S. O intruso, à beira do público e do privado. Dissertação de Mestrado. PUC-Rio, Rio de Janeiro, 2011. p. 25.

30 “Ater-se a pensar o seu outro: o seu próprio outro, o próprio do seu outro, um outro próprio? Ao pensálo como tal, ao reconhecê-lo, perdemo-lo. Reapropriamo-lo, dispomos dele, perdemo-lo ou, mais ainda, perdemo-nos (de) o perder, o que, quanto ao outro, retoma sempre ao mesmo." (DERRIDA, 1991, p. 12).

${ }^{31}$ DELEUZE, 2009, p. 317.
} 
percebo. Sendo assim, outrem não é eu nem é outro, mas aquilo que torna possível as posições de eu e de outro e que se liga a uma operação que nos permite conhecer outros mundos ${ }^{32}$. Em outra ocasião, Deleuze sublinha um aspecto dessa discussão que tem grande importância para esta pesquisa, atravessada pela circunstância do encontro com alteridades. Em Diferença e repetição, ele enuncia uma espécie de regra de conduta para o encontro com outrem:

A regra que invocávamos anteriormente, isto é, não se explicar demais, significava antes de tudo não se explicar demais com outrem, não explicar outrem demais, manter seus valores implícitos, multiplicar nosso mundo, povoando-o com todos esses expressos que não existem fora de suas expressões. Com efeito, outrem não é um outro $\mathrm{Eu}$, mas o $\mathrm{Eu}$ é um outro, um Eu rachado. Não há amor que não comece pela revelação de um mundo possível como tal, enrolado em outrem que o exprime. O rosto de Albertine exprimia o amálgama da praia e das ondas: "De que mundo desconhecido me distinguia ela?"33

Proust, Tournier... vemos mais uma vez aqui que a reflexão deleuziana sobre o outrem põe lado a lado a criação artística e o encontro com mundos possíveis, sua invenção. $O$ devir-feiticeiro do escritor tem a ver com sua capacidade de trânsito ontológico. Mundos possíveis não são então aqueles que se conhecem objetivamente - na citação, fala-se em amor. Para que outros mundos possam invadir, multiplicar nosso mundo, povoá-lo, é preciso manter os valores desses outros implícitos, tratá-los como expressos que só existem em suas expressões, sem apontar para qualquer coisa conhecida, já concebível.

Por outro lado, ao propor sua compreensão de ficção, o escritor Juan José Saer enfatiza algo nesse espírito:

(...) a ficção não pede para ser crível enquanto verdade, e sim enquanto ficção. Esse desejo não é um capricho de artista, mas a condição primeira de sua existência, porque somente sendo aceita como tal é que se compreenderá que a ficção não é a exposição romanceada de tal ou qual ideologia, e sim um tratamento específico do mundo, inseparável da matéria de que trata. (...) Por causa deste aspecto particularíssimo do relato ficcional, e por causa também de suas intenções, de sua resolução prática, da posição singular de seu autor entre os imperativos de um saber objetivo e das

\footnotetext{
${ }^{32}$ Sigo aqui a pista em Viveiros de Castro (2002b), ao abordar a leitura de Deleuze do livro de Michel Tournier e questionar o conceito de "outrem como estrutura a priori".

${ }^{33}$ DELEUZE, G. Diferença e repetição. Rio de Janeiro: Graal, 1994. p. 12.
} 
turbulências da subjetividade, podemos definir a ficção, de um modo global, como uma antropologia especulativa. ${ }^{34}$

Ao enfatizar que a possibilidade da ficção não se sustenta na proclamação da verdade, Saer está afirmando que a ficção desconsidera critérios objetivistas de verdade. Afirma isso para asseverar a materialidade da ficção que, com suas características peculiares, exige um "tratamento específico do mundo". Nesse sentido, pode-se dizer que, se há um agenciamento entre as experiências filosóficas e artísticas com a ficção, este se dá na investigação/criação de mundos possíveis. De um lado, o mundo que passa por uma intervenção específica é um mundo que se constitui nesse tratamento, já que é inseparável do que trata. Pode-se vê-lo através de um engendramento com a escrita. Esse mundo só existe a partir de uma possibilidade. Esta o faz existir segundo um "salto em direção ao inverificável”35. Existe como um mundo que está sendo inventado, em que os personagens se defrontam nesse contexto e forçam o escritor a ir com eles por uma direção que não se controla completamente e que comporta múltiplas possibilidades.

A finalidade necessária das narrativas decorrentes desses "saltos em direção ao inverificável" é sobretudo a de provocar efeitos a partir de experiências criativas. Nesse sentido, foi com a intenção de conferir certo tom embaçado e nebuloso ao corpo da escrita e à descrição dos acontecimentos a serem narrados que, por exemplo, Guimarães Rosa tantas vezes sugeriu aos seus tradutores a busca pela indeterminação como efeito indispensável a ser perseguido. Em correspondências trocadas com os tradutores, o escritor pede indeterminação para despertar um mundo enredado por forças misteriosas. Mas a opção pelo indeterminado em Rosa se liga, paradoxalmente, a uma busca pela exatidão: fala de sua escrita como uma espécie de "álgebra mágica", acrescentando que se é mágica é "porque é mais indeterminada e, portanto, mais

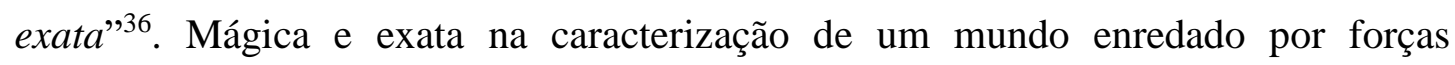
misteriosas, para a pesquisadora Luiza Novaes, a escrita de Rosa é também xamânica:

\footnotetext{
${ }^{34}$ SAER, Juan José. O conceito de ficção. In.: FronteiraZ. Revista do Programa de Estudos PósGraduados em Literatura e Crítica Literária. Tradução de Luís Eduardo Wexell. n. 9, 2012. p. 322324.

${ }^{35}$ Ibid., p. 324.

${ }^{36}$ ROSA, J. G. Diálogo com Guimarães Rosa (Günter Lorenz). In: Ficção Completa. v. 1. Rio de Janeiro: Nova Aguilar, 1994. p. 54.
} 
(...) um escritor particularmente permeável às forças anárquicas da Vida. Afirmando em diversas ocasiões, e isso apesar de sua notória erudição, ter na sensibilidade e na intuição seus principais aliados na criação literária, Rosa estabelece-se como um autor xamânico por excelência. ${ }^{37}$

Entre a erudição abstrata e a sensibilidade, Rosa escolhia a imaginação encarnada de “forças anárquicas da vida". Como se disse, Luiza Novaes vê essa permeabilidade do jogo literário rosiano como um posicionamento xamânico que o artista ocupa. Pensar nessa posição e em seu movimento é lembrar (com Eduardo Viveiros de Castro) que possivelmente há, nesse procedimento artístico, o envolvimento de uma práxis perspectivista que produz um efeito análogo ao modo de pensar indígena. Da escrita de Rosa, se se pode denominá-la mágica, exata, xamânica, lembremos que, para o antropólogo, ela é também um "exercício perspectivista":

(...) a literatura brasileira (e latino americana, e mundial) atinge um de seus pontos culminantes no espantoso exercício perspectivista que é "Meu tio, o Iauraetê", de Guimarães Rosa, a descrição minuciosa, clínica, microscópica, do devir-animal de um índio. (..) Enfim, vejo o perspectivismo como um conceito da mesma família política e poética que a antropofagia de Oswald de Andrade ${ }^{38}$.

Trata-se de uma potência de ação político-poética análoga também àquela encontrada, por Viveiros de Castro, no livro A paixão segundo G.H., de Clarice Lispector. Ele desloca Clarice do espaço ocupado por ela em inúmeras abordagens críticas anteriores, ao afirmar que esse romance, não estando propriamente em continuidade com a obra de Oswald de Andrade, estabelece com ela uma aliança demoníaca ${ }^{39}$ de registro antropofágico comum. Viveiros experimenta a ideia de que, em países periféricos, escritores seriam pensadores da periferia, ideia esta diretamente vinculada ao

\footnotetext{
${ }^{37}$ RIBEIRO, L.N.T. À escuta da língua inarticulada em Guimarães Rosa. Tese de Doutorado. PUCRio, Rio de Janeiro, 2018. p. 20.

${ }^{38}$ SZTUTMAN, Renato (Org.). Encontros: Eduardo Viveiros de Castro. Rio de Janeiro: Azougue, 2008. p. 128-129.

${ }^{39} \mathrm{O}$ ato de ver uma aliança demoníaca entre Clarice e Oswald está também penetrado do conceito de devir-feiticeiro, explorado por Deleuze e Guattari em Mil platôs (lembrando aqui que o devir escapa tanto à imitação e reprodução quanto à história e à memória). Para Viveiros, a aliança que se poderia dizer "demoníaca" se impõe, em Mil Platôs, com a potência de um devir: "O conceito de aliança cessa de designar uma instituição - uma estrutura - e se torna uma potência, um potencial - um devir. Da aliança como forma à aliança como força, passando ao largo da filiação como substância. Não estamos aqui no elemento místico-serial do sacrifício nem no elemento mítico-estrutural do totemismo, mas no elemento mágico-real do devir" (VIVEIROS DE CASTRO, 2007, p. 120)
} 
pensamento deleuzeano, para quem as línguas menores são entregues aos escritores ficcionistas.

Ao estudar os mundos propostos por Oswald, Rosa e Clarice, Viveiros encontra ideias de mundo para além da relação entre humanos, já que o processo de variação não diz respeito somente a uma variação interna à humanidade e acontece de acordo com o deslocamento das subjetividades. O antropólogo diz que, em G.H., a autora desenvolve a herança oswaldiana de modo bastante peculiar - segundo ele, a mulher do livro pratica uma espécie de autofagia. Ele vê, na autofagia da personagem - ao distinguir o suicídio do assassínio de si mesma para indicar uma cisão, uma fratura interna -, a dimensão de um matriarcado antropofágico de tipo paradoxal. "Barata-mãe, barata-antiEva-sem-nome, barata-virgem-maria, numa situação bastante complexa com a feminilidade, com a mulheridade", afirma Viveiros, na palestra "A foça de um inferno: Rosa e Clarice nas paragens da diferOnça" 40 . O livro de Clarice termina com a personagem regressando à sua condição humana sem, contudo, ter estado consciente no momento em que come - ou não? - a barata. Trata-se de uma operação política, na esfera do possível diante da confrontação com um devir. Trata-se de pensar em uma zona onde se dá o devir. Este “está sempre 'entre' ou 'no meio': mulher entre mulheres, ou animal no meio dos outros" ${ }^{41}$. Isto para falarmos com o Deleuze de Crítica e Clínica, para quem, “quando Le Clézio devém índio, é um índio sempre inacabado, que não sabe cultivar o milho nem talhar uma piroga, mais do que adquirir características formais, ele entra numa zona de vizinhança" ${ }^{\prime 2}$.

Assumindo tal vertente de entendimento, vem a ser importante aqui o aspecto de que o devir se deixa compreender como limiar (sinônimo de véspera). Assim como, para Nancy (citando Blanchot), escrever um sentido ausente não é escrever uma falta de sentido ${ }^{43}$, o que vem a ser importante, portanto, é pôr em destaque fazeres artísticopensantes, imaginados como uma tentativa de "formar" sentido na beirada do discurso: não como algo que escape ao discurso como se escapa de uma região, mas como um

\footnotetext{
${ }^{40}$ Palestra proferida em abril de 2013.

${ }^{41}$ DELEUZE, 2011, p.12.

42 Ibid.

${ }^{43}$ BLANCHOT apud NANCY, Jean-Luc. El sentido del mundo. Tradução de Jorge Manuel Casas. Buenos Aires: La Marca, 2003. p. 5.
} 
espasmo do discurso, abandonando a pretensão de sentido lógico que porventura pretenda "formar" um conteúdo ${ }^{44}$.

Walter Benjamin explorou essa vereda. A produção de conhecimento a partir do pensar por imagem de Benjamin, numa reversão radical da oposição platônica eikasia $\mathrm{X}$ dianoia, nasce como possibilidade da experiência de alteridade através do engendramento do corpo em investigações do espaço urbano e do contato direto com o sensível no campo artístico. É por aqui que começamos a aproximar Benjamin de uma certa magia do saber: "[a] imagem possibilita o acesso a um saber arcaico e a formas primitivas de conhecimento, às quais a literatura sempre esteve ligada, em virtude de sua qualidade mágica e mítica". ${ }^{45}$ Para além do projeto sobre as passagens urbanas parisienses do século XIX e seguindo sua afinidade estético-política com o movimento surrelista, em 1929, Benjamin publica o ensaio "O surrealismo: O último instantâneo da inteligência europeia”. E é por esse texto que podemos nos aproximar ainda mais de uma imaginação como experiência ou como o que Benjamin chama de "exatidão automática" 46 com a qual, nos procedimentos escriturais surrealistas, interpenetravam-se "som e imagem, imagem e som"47 numa operação eficientemente mágica onde parecia de fato, como assinala o filósofo, "que não sobrava a mínima fresta para inserir a pequena moeda a que chamamos 'sentido" "48. Em alguns textos surrealistas, temos realmente a sensação de que o sentido lógico passou por nós e seguiu adiante, tal é o efeito libertador dessa imaginação poética.

Embora posteriormente tenha percebido na proposta surrealista uma incapacidade de cumprir seu potencial revolucionário, Benjamin explora outros de seus procedimentos. Entre eles, a análise do material onírico fortemente presente nas escritas surrealistas. Para o filósofo, trata-se de uma percepção de afrouxamento da individualidade por meio da embriaguez do sonho, que leva "a experiência viva e

\footnotetext{
${ }^{44} \mathrm{O}$ pensamento de Nancy, numa das ocasiões em que problematiza as relações entre poesia e sentido, surpreende a escrita do sentido ausente como um modo "capaz de renegar-se [a própria escrita poética], de denegar-se ou de suprir-se. No que se nega, a poesia nega que o acesso ao sentido possa ser confundido com um modo qualquer de experessão ou de figuração (NANCY, 2013, p. 417).

${ }^{45}$ BOLLE, Willi. Fisiognomia da metrópole moderna: representação da história em Walter Benjamin, Edusp, 1994. p. 43.

${ }^{46}$ BENJAMIN, Walter. Magia e técnica, arte e política. Obras escolhidas. v. 1. Tradução de S. Paulo Rouanet. São Paulo: Brasiliense, 2012. p. 23.

${ }^{47}$ Ibid.

${ }^{48}$ Ibid.
} 
fecunda que permitiu a esses homens [os artistas] fugir do fascínio da embriaguez"49. Para Benjamin, “é um grande erro supor que só podemos conhecer das 'experiências surrealistas' os êxtases religiosos ou os êxtases produzidos pela droga"50. O que ele diz que admira nas experiências surrealistas é a "superação autêntica e criadora da iluminação religiosa" ${ }^{51}$ : iluminação profana que se percebe em algumas obras. Uma de suas favoritas é Nadja, de André Breton. Ele a menciona nesse ensaio sobre o surrealismo.

Coloquemos então o seguinte: como parte desse campo de atuação, trata-se aqui de apresentar alguns materiais poéticos que, em suas distintas forças e vetores, desdobram a crise da representação (essa crise tão ampla) levada em sua radicalidade pelas vanguardas históricas. Seguindo, portanto, o interesse suscitado pelos leitores de Nietzsche aqui mencionados, trata-se de apresentar fazeres que investigam o mundo e transitam artisticamente na esteira do projeto de reversão do platonismo. No caso dos materiais surrealistas, circundados por uma lógica onírica, estes habitam certo espaço entre instâncias da consciência e a da inconsciência, em conexão com a embriaguez dionisíaca, buscando afirmar o potencial criativo da vida.

A partir de relatos de sonhos e de sonos induzidos, a experimentação da escrita automática e os estudos sobre o automatismo (procedimento poético adotado por André Breton) acontecem a partir do contato do poeta francês com o Dadaísmo, em 1920, até ele se desligar do movimento, em 1922. Neste período, as experimentações coletivas vão se desdobrando e abarcando artistas de diversos matizes. Entre eles, os escritores Louis Aragon e Philippe Soupault, e os artistas plásticos Pablo Picasso, Marcel Duchamp e Max Ernst. São fazeres que contêm em si uma estranha perda: a da fixidez. Com essa perda, ganha-se impermanência e propõem-se novas associações. Pelo entrelaçamento de ideias, fluxo livre e sem controle de associações como forma escritural e pela perda de entraves da razão humana, interessa a esses artistas a liberação de um imaginar onde há contato:

\footnotetext{
${ }^{49}$ BENJAMIN, 2012, p. 23.

${ }^{50} \mathrm{Ibid}$.

${ }^{51}$ Ibid.
} 
(...) antes de adormecer, percebi, nitidamente articulada a ponto de ser impossível mudar-lhe uma palavra, mas bem separada do ruído de qualquer voz, uma frase bem bizarra que me alcançava sem trazer indício dos acontecimentos aos quais, segundo o testemunho de minha consciência, eu estava preso, nessa ocasião, frase que me pareceu insistente, frase, se posso ousar, que batia na vidraça. Rapidamente tive a sua noção, e já me dispunha a passar adiante quando o seu caráter orgânico me reteve. Na verdade, esta frase me espantava; infelizmente não a guardei até hoje, era algo como: "Há um homem cortado em dois pela janela", mas não poderia haver ambiguidade, acompanhada como estava pela fraca representação visual de um homem andando, e seccionado a meia altura por uma janela perpendicular ao eixo de seu corpo. Fora de dúvida era a simples aprumação no espaço de um homem debruçado à janela. Mas esta janela tendo seguido o deslocamento do homem vi que se tratava de uma imagem de tipo bastante raro e logo pensei em incorporá-la a meu material de construção poética. Assim que lhe concedi este crédito ela deu lugar a uma sucessão quase ininterrupta de frases que não me surpreenderam menos e me deixaram sob a impressão de uma tal gratuidade que me pareceu ilusório o império que até então eu mantinha sobre mim mesmo (...). ${ }^{52}$

São fazeres que duvidam do familiar e do idêntico: desprezando construções lógicas e racionais, como característica da amostra trazida aqui, vale salientar que interessa tudo que intriga, em várias frentes de pesquisas e experiências inventivas que vão desaguar num feixe de atravessamentos, como acontece, por exemplo, na atitude delirante do poeta e dramaturgo Antonin Artaud.

Lembremos que, após a ruptura com o movimento surrealista, Artaud assiste aos espetáculos de dança balinesa na Exposição Colonial, em Paris, em 1931. A partir daí desenvolve uma série de reflexões que vão desembocar na proposta de renovação do sentido de teatro no Ocidente, a partir de uma linguagem que pudesse captar a magia do cosmos e do divino:

O teatro de Bali revelou-nos uma noção de teatro física, não verbal, na qual o teatro está contido nos limites de tudo o que pode acontecer num palco, independentemente do texto escrito, enquanto que, tal como nós o concebemos no Ocidente, o teatro se aliou ao texto e por ele se encontra limitado. Para o teatro ocidental a Palavra é tudo e não há, sem ela, possibilidade de expressão; o teatro é um dos ramos da literatura, uma espécie sonora da linguagem e mesmo que admitamos uma diferença entre o texto falado no palco e o texto lido pelos olhos, se restringirmos o teatro ao que acontece entre as deixas, não conseguimos, mesmo assim apartá-lo da noção de um texto representado. ${ }^{53}$

52 BRETON, André. Manifesto Surrealista. Disponível em: <http://www.culturabrasil.org/zip/breton.pdf>. Acesso em: 4 jun. 2020.

${ }^{53}$ ARTAUD, Antonin. O teatro e seu duplo. Tradução de Mônica Stahel e Teixeira Coelho. São Paulo: Editora Martins Fontes, 2006. p. 75. 
Como se vê, neste capítulo que pensa o imaginar no Ocidente, importa registrar fazeres que se atrevem pelo mundo, afrontando a condição de impasse que abreviei nas palavras de Henry Miller: interessa ver o que está para além de nossos olhos e escrever, com o corpo livre da cadeira elétrica, os imaginários de culturas distantes. A busca por um tipo de estranhamento - que, segundo Artaud, não poderia ser encontrado nos livros, nas pinturas, nas esculturas - leva o artista ao México, em 1936:

E foi no México, no alto da montanha, entre agosto e setembro de 1936, que eu comecei a me encontrar completamente... Eu procurava o peyote não como um curioso, mas, ao contrário, como um desesperado..., contrariamente ao que se podia pensar, eu nunca busquei o supra-normal. Ora, eu não ia ao peyote para entrar, mas para sair, sair de um mundo falso. ${ }^{54}$

Defendendo uma relação intensa entre teatro e vida, Artaud foi viver com o povo indígena Tarahumara. Ali, experimenta o impacto do ritual xamânico do peiote (pequeno cacto nativo do México e do sudeste dos EUA, cujo principal componente psicoativo é a mescalina que causa alucinações, sinestesia e percepção distorcida do espaço e do corpo; em pessoas predispostas ao risco, seu uso pode desencadear surtos psicóticos e de pânico). O motivo de sua viagem era também o de buscar cura para seus problemas psíquicos e físicos, inclusive para o uso contínuo de morfina a fim de aliviar agudas dores de cabeça. Ao retornar a Paris, o artista é internado num hospital psiquiátrico.

Procurando os segredos eternos de uma cultura (para ele, exótica), os relatos de Artaud sobre sua viagem ao "país dos tarahumaras" também reafirmam distâncias, ao revelarem mais sobre os anseios de um artista moderno no período entre guerras europeu do que sobre a própria forma de vida da tribo mexicana. Talvez a "regra de conduta" deleuziana - manter implícitos os valores de outrem - não tenha vigorado plenamente - neste e em outros gestos ocidentais de afastamento do Ocidente. Talvez não seja uma regra de todo exequível.

\footnotetext{
${ }^{54}$ ARTAUD apud LINS, Daniel. Antonin Artaud: o artesão do corpo sem órgãos. In.: A lógica do ato psicanalítico, 1999. p. 96-97.
} 
Seja como for, algo no modo de vida de outros povos - algo no modo como viviam "experiências visionárias típicas do xamanismo"55 — nos faz lembrar de antropólogos de inspiração surrealista que, como Bataille, estudaram temas ligados a esse jeito longínquo de viver. Lembremos desses viajantes (ou não) que trabalhavam em estado delirante (ou não). Lembremos que estão em jogo aqui fazeres construídos em função do trânsito entre os mundos da investigação, da percepção, da análise e da invenção.

Alguns antropólogos — Michel Leiris, George Bataille e Roger Caillois formam a dissidência do surrealismo. Reagindo a um suposto idealismo artístico bretoniano, eles fundam o Colégio de Sociologia, em 1937, frequentado por, entre outros, Walter Benjamin. O grupo de Bataille clamava por um tipo de alternativa ao projeto do humanismo francês que seria o Musée de l'Homme, aberto em 1938, após a destruição, no ano anterior, do Musée d'Ethnographie du Trocadero.

Antes, em 1929, com Leiris e Carl Einstein, Bataille funda a revista Documents, um periódico de vanguarda que tinha o corpo como alvo favorito do projeto editorial. Em Documents, observa-se o uso de inusitadas justaposições, a partir da colagem ao acaso de imagens, textos, objetos, rótulos, com o propósito de perturbar os símbolos estabelecidos para provocar estranhamento, romper com o convencional e pôr em questão a própria cultura, resistindo, assim, ao senso comum. Aqui, é interessante ressaltar não apenas as fragmentações e justaposições fortuitas. Em Documents, tratava-se de lidar com a gradativa ascensão do fascismo àquela altura do período entre guerras. Lidava-se com uma situação de impasse, vivendo-se o lado patético dessa situação a partir de uma estratégia crítico-reflexiva que aproximava diferenças incompatíveis. Tratava-se, pois, de proceder um modo de aproximação em que a tensão permanecesse. Depois que os corpos de palavras, imagens, objetos, rótulos se aproximavam e se amalgamavam, era a tensão, a partir da dimensão paradoxal do sentido, que deflagrava o questionamento da própria cultura.

Para além de escolas literárias ou picturais, passando pelo choque de imagens e objetos antagônicos cuja potência é detectada pelos etnógrafos vanguardistas da revista

\footnotetext{
${ }^{55}$ LAGROU, Els. A arte do outro no surrealismo e hoje. In.: Horizontes Antropológicos. 2008. p. 224-
} 228. 
Documents, cabe trazer aqui também Marcel Duchamp. A experiência infraleve buscada por ele, e conhecida pelo público a partir da última grande exposição do movimento surrealista, na galeria Maeght, em Paris, em 1947, certamente nos faz pensar sobre o modo desencarnado de imaginar no Ocidente, uma forma organizada de maneira a evitar também o contato entre corpos e a própria experiência. Nessa exposição, Duchamp dedica-se a apresentar uma série em látex a partir de moldes dos seios de sua amante, a escultora brasileira Maria Martins. Ao olhar para esses moldes, o público via a inscrição, Pede-se tocar: "essas próteses são um exemplo de deslocamento do visível ao tátil que, lançando mão de materiais não convencionais, procuram uma experiência infraleve" $" 56$ - experiência mágica, nos termos de uma imperceptibilidade. "Infraleve" (traduzido do francês "inframince") é este conceito duchampiano recuperado por Raúl Antelo, tratado em seu livro Maria com MarcelDuchamp nos trópicos (2010), e merece menção no contexto desta pesquisa. Duchamp descreve o "inframince" no conjunto de notas escritas no período de 1915 a 1923, que compreende também a criação de seu trabalho "O grande vidro" ou "A noiva despida por seus celibatários, mesmo":

O infraleve é o mais ínfimo dos intervalos, ou a menor das diferenças. (...) O calor de um assento (que acabou de ser deixado) é infraleve $\left(n^{\circ} 4\right)$ (...) Portões do metrô - as pessoas / que os atravessam bem no último momento / Infraleve - ( $\mathrm{n}^{\circ} 9$ reto) Calças de veludo - / seu som de assobio (ao caminhar) pelo / roçar das 2 pernas em uma / separação infraleve sinalizada / pelo som. (não é um som infraleve) (n 9 verso) (...) Diferença entre $o$ contato / da água e $o$ de / chumbo derretido por ex., / ou do creme / com as paredes de seu / próprio recipiente movidas ao redor do líquido... essa diferença entre dois contatos é infraleve. $\left(\mathrm{n}^{\mathrm{o}} 14\right) .{ }^{57}$

Ler essas reflexões em torno do processo imaginativo, levadas ao extremo por Duchamp, mediante o esgotamento das noções tradicionais de campo artístico e de formas artísticas me faz lembrar metonimicamente do virulento devir-feiticeiro aqui

\footnotetext{
${ }^{56}$ ANTELO, Raul. Poesia e imagem. In.: Gragoatá. v. 11, n. 20, 2009. p. 3.

${ }^{57}$ No original: "The infrathin is the most minute of intervals or the slightest of differences (...) The warmth of a seat (which has just been left) is infra-thin ( $\mathrm{n}^{\circ}$. 4) (...) Subway gates - the people / who go through at the very last moment / Infra thin $-\left(\mathrm{n}^{\circ} 9\right.$ recto) Velvet trousers $-/$ their whistling sound (in walking) by / brushing of the 2 legs is an / infra thin separation signaled / by sound (it is not an infra thin sound) ( $\mathrm{n}^{\circ} 9$ verso) (...) Difference between the contact / of water and that of / molten lead for ex, / or of cream / with the walls of its / own container moved around the liquid.... this difference between two contacts is infra thin. ( $\left.{ }^{\circ} 14\right)$ " (DUCHAMP apud PERLOFF, 2002. p. 114-116).
} 
mencionado. Interessam-me, para circunstanciar a pesquisa que aqui apresento, fazeres deste tipo, que se expandem na direção dessa ênfase, realizando um impuro movimento, uma abertura, que se mobiliza em torno da passagem de um gesto formal para um gesto ético, levando em conta sempre o lugar da arte na contemporaneidade.

E pensar historicamente nesses fazeres é também pensar em instalação e performance. Em 1965, Joseph Beuys caminha por uma galeria de arte durante três horas, em Dusseldorf, na Alemanha, carregando consigo uma lebre morta. Estava caracterizado como um xamã, com o rosto e o corpo cobertos por uma tinta dourada. Enquanto caminha pela galeria, Beuys apenas move os lábios em silêncio como se explicasse as imagens - as obras de arte - ao animal morto.

“Como explicar quadros para uma lebre morta” é uma das obras inaugurais da instalação e da performance: práticas que, em suas múltiplas conotações, transformam, em muitos sentidos, o panorama das artes. Não que, depois disso, tenha ocorrido um recomeço absoluto; todos sempre pegamos um bonde andando. Tampouco, é claro, no sentido de uma refundação sistemática e tranquilizadora da arte. Todavia, a emergência histórica da instalação e da performance marcam uma diferenciação importante no estatuto da arte no Ocidente. Desde então, inquietam e perturbam sem cessar nossos modos de imaginação artística.

Os caminhos abertos pela instalação e pela performance foram também uma reação à arte considerada mercadoria, bem como à produção de massa e ao consumismo. Como no caso das estratégias dos procedimentos duchampianos, tais ações artísticas sempre aconteceram de modo particularmente provocativo.

$\mathrm{Na}$ esteira dessa ruptura, é que instalações, happenings e performances - como as do Movimento Fluxus - tomaram a cena artística nas décadas de 1960 e 1970. O Fluxus foi fundado por um grupo de artistas, compositores e designers de várias partes do mundo ocidental, entre eles, John Cage, George Maciunas, Yoko Ono, Nam June Paik e Carolee Schneemann.

Os artistas do Fluxus queriam que o cotidiano fosse incorporado à arte. Interessavam-se pela relação do espectador com a obra de arte e pretendiam transpor a lacuna entre a arte moderna e a vida. Em vez de uma autoexpressão, que eles 
acreditavam supervalorizar o indivíduo, defendiam uma arte política que estava interessada no mundo e nos temas sociais a ele inerentes.

O Fluxus se expandiu para admitir vários outros artistas, sendo que o mais importante deles foi justamente o alemão Joseph Beuys mencionado acima.

Além da citada lebre morta, vale destacar como exemplo aqui mais uma obra de Beuys: "Eu amo a América e a América me ama" (1974). Ele voou para Nova Iorque onde foi enrolado num cobertor e levado de ambulância para uma galeria. Lá, dividiu a sala durante três dias com um coiote selvagem (considerado uma divindade por povos nativos). $\mathrm{O}$ artista interagia com o coiote dormindo numa cama de palha, vagando com um cajado de pastor e jogando luvas de couro para o animal. A performance acabou quando Beuys o abraçou. Além disso, ele lidava com materiais nada próprios ao pintor ou escultor - gordura, cera de abelha, mel, feltro, cobre. Em todos os seus fazeres, o artista alemão, dos mais consagrados do século XX, pretendeu decompor e descontruir os critérios de verdade objetivista vigentes e, por conseguinte, expressou a necessidade de se compreender a arte tanto sensorial e relacional quanto intelectualmente.

O envolvimento de corpos sugere a estreita ligação da arte performática com um fazer. Diante da busca por uma imaginação artística que mobilize um corpo e uma experiência, gostaria de assinalar ainda o exemplo de uma artista que usava performances ritualísticas em seus fazeres e seu corpo como material para suas criações: a cubana Ana Mendieta. Ela toca a face extrema da "vida de artista" 58 de que fala Roberto Correa dos Santos. Entre os exemplos citados pelo pesquisador, assinalo especialmente Death of Chicken (1972) e Blood and Fealthers (1974). Na primeira performance, Mendieta aparece segurando uma galinha morta recém decapitada e, enquanto o animal convulsiona, o sangue é jorrado no corpo da artista que, por sua vez, carimba as paredes com o próprio corpo e o sangue da galinha. Na segunda performance, Mendieta aparece nua, parada à margem arenosa de um riacho, ergue um frasco ao nível do ombro e começa a derramar sangue pelo corpo. Em seguida, mergulha em um monte de penas brancas. Estas aderem ao sangue pegajoso e a artista

\footnotetext{
${ }^{58}$ SANTOS, Roberto Corrêa dos. Uma vida de artista. In: Conferência de encerramento de Atividades Acadêmicas promovidas pelo corpo discente do Programa Pós-Graduação em Literatura, Cultura e Contemporaneidade do Departamento de Letras da PUC-Rio. Rio de Janeiro: 2012. Disponível em: <https://www.youtube.com/watch?v=h41ZsUobYhM\&t=899s>. Acesso em: 4 jun. 2020.
} 
se levanta para ficar de pé com os braços afastados do corpo e os cotovelos inclinados como se imaginasse ser uma ave de asas abertas.

Citando o exemplo de Mendieta, Roberto Corrêa dos Santos aborda algo que nos faz retornar à cumplicidade entre imaginação e vida: "tornar-se artista e de algum modo tornar-se a obra e nem ser mais senhor de si e ser a coisa que erra e que se move e que considera que cada ato é de uma plenitude tão ardorosa num movimento amplo que não tem identidade" 59 .

Oswaldianamente, trata-se da experiência vital, necessária e canibal por excelência de vivenciar a troca de energias poéticas e imagéticas em relação material com as forças lúdicas e mágicas da vida. Para além da fragilidade diante de um mundo enredado por forças misteriosas, tal troca fornece elementos de arriscada performance justamente por envolver um momento limite para o corpo; e outras formas de vida para as quais a arte aponta, mantendo-se aberta à filosofia e ao pensamento crítico.

Acredito que a força da configuração parcial posta em destaque até aqui serve como um aceno na direção do enfoque que norteia este trabalho. Nesse sentido, acredito que os movimentos brevemente descritos neste capítulo trazem à luz instantes que parecem pensar um imaginar outros mundos de modo distinto do platônico. Parecem de algum modo dizer: mas o corpo... Será?

\section{4.}

Vida de artista, vida de índio

Mais do que uma coletânea de abordagens já conhecidas, estiveram em jogo até aqui fazeres pensantes que experimentam um modo artístico de estar no mundo. Para isso, pretendo ainda lançar mão, neste capítulo, da força de performances menos celebradas nisso que chamamos de Ocidente, mas que também operam na imprevisibilidade, na beirada de um abismo entre mundos. Como a performance do xamã, quando "viaja" para outros mundos e se expõe ao risco de um momento limite

\footnotetext{
${ }^{59}$ SANTOS, 2012.
} 
para o corpo e volta para contar esse acontecimento, que promete ser uma experiência de alteridade radical.

A performance do xamã possui a condição da arte a nos fascinar e nos propor enigmas. A arte nos convida a ir com ela ao desconforto, à vertigem, em fazeres que despertam forças contraditórias - uma possível vontade de aplacar o desconforto se choca frontalmente com um desejo de deixar-se ficar nessa vertigem. Nesta perspectiva, então, fazeres artísticos se tornam tanto mais arriscados quanto mais se investem de ato tradutório: não de um texto para outro, mas da possibilidade de tocar uma outra forma de vida, sem que se pense que se é uma coisa em si mesma e que o outro é uma outra coisa em si mesma. Pode-se apostar, por exemplo, que fazeres artísticos nos oferecem possibilidades de alterar nossas formas de vida. Não? Sim? Pode-se apostar na vertigem de conhecer, por exemplo, o "Canto da castanheira" — há não muito tempo, esse canto apareceu na minha vida, vida de artista, sou escritora.

O "Canto da castanheira" foi entoado na madrugada de 26 de dezembro de 1982 pelo poeta-xamã Kãñïpaye-ro. A experiência de possessão aconteceu numa aldeia Ipixuna do povo Araweté e chegou até nós através do trabalho antropológico de Eduardo Viveiros de Castro. Com sua tese de doutorado, Araweté - Os deuses canibais, Viveiros é o primeiro a divulgar, traduzir, descrever e analisar o canto.

Antônio Risério foi encontrar na travessia da tese de Viveiros de Castro uma possibilidade para retomar o "Canto da castanheira" e retraduzir esse "ato performágico"60, que é parte de um modo de viver dos Araweté. "A irrupção noturna dos cantos xamânicos é diária, independendo de conjunturas de crise ou da iminência ou atualidade de ritos coletivos", diz Risério, acrescentando que "[é]para isso que existem os pajés"61. Transitando entre céu e terra, a performance xamânica faz acontecer o contato entre deuses e humanos, numa zona de indiscernibilidade. Região em que se embaraçam vozes nessa "poemúsica tribal"62, de que fala Risério. Para ele,

\footnotetext{
${ }^{60}$ RISÉRIO, Antônio. Textos e tribos: poéticas extraocidentais nos trópicos brasileiros. Rio de Janeiro: Imago, 1993. p. 165.

${ }^{61}$ Ibid.

${ }^{62}$ RISÉRIO, Antonio. Palavras canibais. In.: Revista USP, n. 13, p. 23-46, 1992. p. 27.
} 
“o que Viveiros deseja [com a apresentação do canto] é propor uma visão da metafísica araweté"63.

Álvaro Faleiros, por sua vez, resolveu fazer uma retradução em relação às traduções de Risério e Viveiros. Além da evidente diferença entre ambas, Faleiros observa que a tradução estrangeirizante de Risério, ao pretender deixar falar um estranho, perde em eficiência tornando-se meramente opaca:

O estranhamento, contudo, não chega a provocar, acredito, nenhuma deformação ou subversão de ferramentas conceituais: Risério opera plenamente dentro da lógica textual das poéticas ocidentais no que concerne a organização textual; a "forma poema" é reconhecível, codificável. O estranhamento é, pois, superficial, pois se restringe ao léxico e, nesse nível, torna-se pura opacidade. ${ }^{64}$

Ao estudar o canto, Faleiros reafirma ainda "a complexidade do agenciamento enunciativo presente nos cantos xamanísticos dos Araweté" ${ }^{65}$, complexidade esta anteriormente já sublinhada por Viveiros. Tipicamente, o canto Araweté põe em jogo as vozes do xamã, dos deuses e dos mortos. Enquanto o antropólogo nos apresenta uma tradução livre, com marcações em separado; e Risério, uma experiência de caoticidade por não sabermos ao certo quem, das diversas vozes no dentro-fora da voz xamânica, está falando em cada verso; Faleiros, em sua retradução, incorpora as explicações ao canto (também com marcações da ação performática, como a sinalização do que faz o corpo do xamã, a batida do cajado no chão etc) e vai nomeando quem fala: a ponto de daí exibir-se outra faceta (mais organizada, se é que isso é possível); e dela, fluir mais uma performance:

O Canto da Grande Castanheira Celeste, por Kãñïpaye-ro Araweté

[Madrugada de 26 de dezembro de 1982, Kãñïpaye-ro sai de sua maloca e começa a entoar. Eu sou Kããnïpaye, filha morta de Kãñïpaye-ro, escutem agora meu canto, escutem, que agora falo, aqui, pela voz de meu pai...]

Nai dai dai

Nai dai dai

\footnotetext{
${ }^{63}$ RISÉRIO, 1992, p. 27.

${ }^{64}$ FALEIROS, Álvaro. Emplumando a grande castanheira. In.: Estudos avançados, v. 26, n. $76,2012$. p. 62 .

${ }^{65}$ Ibid, p. 57.
} 
Nai dai dai...

Por que você, espírito, empluma a grande castanheira celeste?

Por que os espíritos agora emplumam essa grande castanheira?

Diga-me, Modida-ro, você espírito-avô que habita o outro lado do céu.

Por que os espíritos solteiros emplumam a face da grande castanheira?

Vejo aqui os espíritos emplumando a face da grande castanheira,

Ararīñã-no", espírito-irmão do meu pai que habita o outro lado do céu.

Vejo aqui os espíritos emplumando essa grande castanheira.

[Plumagem branca de harpia, plumagem branca de harpia, cobre a grande castanheira, assim fazem os espíritos porque irados com a morta; por ela ardem de desejo; descem então à terra.]

[Início do segundo refrão. Aumento de volume vocal e de intensidade afetiva.]

Kadïne-kãñï [Arara azul-amarela, espírito-Mulher-Canindé]

Kadïne-kãñi [Arara azul-amarela, espírito-Mulher-Canindé]

Kadïne-kãñi [Arara azul-amarela, espírito-Mulher-Canindé]

[Kãñïpaye-ro entoa mais forte e alto, bate o pé repetidamente]

Kadïne-kãñï... Os espíritos estão aqui

Kadïne-kãñï... Emplumando a face da castanheira.

Kadïne-kãñi... Por que os espíritos fazem assim?

Kadïne-kãñi... Emplumando a grande castanheira.

Kadïne-kãñi... Os espíritos estão aqui, estão aqui.

Kadïne-kãñï... Emplumando a face da castanheira.

Kadïne-kãñi... Os espíritos estão aqui, estão aqui.

[Kãñïpaye-ro já não bate o pé]

Kadïne-kãñï... Porque deseja sua filha, por isso o espírito falou.

Kadïne-kãñi... Vamos emplumar a castanheira, foi isso que o espírito disse .

Kadïne-kãñi... A gente não comeu jaboti,20 o espírito disse assim.

Kadïne-kãñï... Por que os espíritos fazem assim?

Vamos emplumar a castanheira, por que disseram assim?

Veja aqui os espíritos emplumando a face da grande castanheira,

Modida-ro, você espírito-avô que habita o outro lado do céu.

Veja aqui os espíritos emplumando a face da grande castanheira,

Arariñãano", espírito-irmão do meu pai que habita o outro lado do céu.

Acenda meu charuto abandonado, disse o espírito.

[E a esposa do xamã acende seu charuto.]

Aqui os espíritos agora emplumam a grande castanheira, ei-los.

[Movimentos de chocalho sobre o peito da esposa.]

Kadïne-kãñï... É isso o que os espíritos disseram:

Vamos emplumar a grande castanheira, eles se entredisseram.

Porque desejam nossa filhinha,

Por isso os espíritos disseram: vamos emplumar a grande castanheira.

[Fala Yowe'ï-do, espírito-pai da menina morta] 
Kadïne-kãnii... Por que os espíritos fazem assim,

Emplumando a face da castanheira?

[Retoma a palavra na voz do pai, Kããnïpaye, a menina morta]

[Longa pausa... Silêncio... Kãñïpaye-ro agachado fuma. Ouvem-se as batidas cadenciadas de seu chocalho; quando repete o refrão inicial...]

Nai dai dai

Nai dai dai

Nai dai dai...

Por que você, espírito, empluma pela manhã a face da castanheira?

Por que você, espírito, empluma a face da castanheira?

Acenda meu charuto abandonado, disse o espírito.

Por que você empluma a face da castanheira?

[Responde Yowe'ï-do, espírito-pai da menina morta...]

Por desejar nossa filhinha, disse o espírito a si mesmo,

Ararīñã-no", espírito-irmão do meu pai que habita o outro lado do céu.

[Volta Kããnïpaye, a menina morta...]

Por que os espíritos ficam assim, a errar suas flechas nos tucanos grandes?

Por que você, espírito, empluma a face da castanheira?

Ande, disse o espírito, passe sua filha para mim.

[E agora falam os espíritos assim...]

Por sua causa, realmente, se emplumam as castanheiras,

Nai dai dai

Nai dai dai

Nai dai dai...

Ande, disse o espírito, não me serviram o jabuti.

[Volta Kããnïpaye, a menina morta]

Por que os espíritos solteiros emplumam assim a face das castanheiras?,

Diga Modida-ro, você espírito-avô que habita o outro lado do céu.

Por que os espíritos emplumam assim a face da castanheira?

[De novo fala o espírito...] Vou devorar o finado Kãñïpaye-ro.

[Ponto alto, aumento considerável de intensidade; voz mais grave, entoação macabra; entusiasmo da audiência...]

Assim o espírito me levará, para cozinhar-me em sua panela de pedra.

Comeremos seu finado pai, os espíritos disseram repetidamente.

Vão cozinhar-me em sua panela de pedra, disseram repetidamente.

Vão me devorar, é o que disseram, do outro lado do céu.

[É ele mesmo Kãñïpaye-ro quem fala]

Peça à sua filhinha, disse o espírito,

Nai dai dai

Nai dai dai

Nai dai dai...

Para nós dois irmos, disse o espírito, flechar os tucanos grandes. 
[Ir flechar tucanos, ir pro mato fazer sexo; o espírito te deseja menina, se fores, teu pai, Kãñïpaye-ro, quando morrer, poderá ser devorado pelos espíritos, tornar-se um afim]

Por que você, espírito, unta de urucum a face da castanheira?

[Volta a dizer Kããnïpaye, a menina morta]

Aqui estão os espíritos untando, untando toda a face da castanheira.

[Kãñïpaye-ro bate aqui o pé no chão, bate o chocalho sobre a esposa]

Por que os espíritos assim fulguram a face da castanheira?

Diga Yowe'ï-do, espírito-meu-pai que habita o outro lado do céu?

Ande, passe sua filhinha para mim.

[No patamar celeste, um homem - Kãñipaye-ro - se aproxima, os espíritos o chamam de comedor-de-pequenos-jabotis...]

Eeeeh!

Um comedor-de-pequenos-jabotis, disseram os espíritos, afugentou as cotingas.

Nai dai dai

Nai dai dai

Nai dai dai...

Nossa futura comida, disseram os espíritos, afugentou as grandes juritis.

A plumagem das grandes araras-canindé-eternas, as grandes cotingas,

Disseram os espíritos, ande, vamos flechar os grandes tucanos.

Eeeeh!

[Kãñipaye-ro sintetiza o diálogo ocorrido do outro lado do céu...]

Quanto àquilo de os espíritos pedirem a filha, não precisavam pedir.

Nada me foi oferecido, ande, disse o espírito, me passe os pequenos jabotis.

[O canto vai se concluindo, alternam-se a menina e o xamã...]

Por que você empluma a face da castanheira?

Eeeeh! Nossa futura comida afugentou as grandes juritis.

Por que você empluma a grande árvore cheirosa iciri'i?

Por vontade de levar a mulher para caçar,

$\mathrm{O}$ espírito empluma a face da castanheira.

Por que você unta de urucum a face da grande iciri'i?

Por que os espíritos acabam com meu tabaco?

Nosso chão é cheiroso, disse o espírito.

Nai dai dai

Nai dai dai

Nai dai dai...

Assim que untar a grande iciri'i, disse o espírito,

Vamos nos perfumar um ao outro com sua resina.

Por que os espíritos emplumam a face da castanheira? 
[A partir do último verso, a voz vai morrendo aos poucos, repetindo o refrão...]

Nai dai dai

Nai dai dai

Nai dai dai...66

Quando a princípio considerei deixar que o "Canto da castanheira" se insinuasse aqui entre fazeres artístico-pensantes articulados em língua ocidental, como leitora e pesquisadora, neste ponto do percurso deste estudo, diante de verso após verso, queria me dedicar a pensar e escrever sobre sua singularidade constitutiva a partir das leituras de Viveiros, Risério e Faleiros.

Mas então agora um detalhe importante desse universo ameríndio remete a coisas de minha própria forma de vida, coisas que eu nunca havia notado, como se um estranho em mim mesma começasse a falar quando começou a falar no corpo do poetaxamã a forma de vida dos Araweté.

Acontece que os fragmentos desse canto xamanístico, que é também um poema, uma narrativa, uma escrita dramatúrgica, uma performance, uma cena de possessão..., tais fragmentos enfim evocam algumas outras histórias por contar.

Fui apresentada ao canto de Kãñipaye-ro em uma disciplina ministrada por Helena Martins no programa de pós-graduação em Literatura, Cultura e Contemporaneidade. De pronto suas palavras causaram-me espanto. Lembro-me de ter pensado o quanto a vida ameríndia, mais do que incompreensível, era até ali invisível para mim.

Mas não havia como não ser fisgada pela melodia de uma palavra em especial. Tentarei aqui, de passagem, entoar essa melodia arisca que insiste em fugir, mas que retorna para mim como a imagem íntima de uma Castanheira.

Na noite de 26 de dezembro de 1982, quando Kãñïpaye-ro apresenta seu canto à gente da tribo, fora de qualquer calendário ritual, é possível observar, a cerca de 2.500 quilômetros dali, alguns detalhes adolescentes de uma menina de 14 anos de idade. Vivendo no interior de Minas Gerais, é no adro da igreja matriz transformado em pista improvisada de patinação que gosto de imaginá-la. Até hoje a vejo ali, exultante,

${ }^{66}$ FALEIROS, 2012, p. 65-69. 
aprendendo a deslizar com os patins que ganhara de presente de Natal e a experimentar uma ínfima sensação de liberdade e uma vontade muito grande de confrontar os domínios daquela vida com outras fronteiras. Numa foto da véspera, é possível vê-la com outras pessoas em torno da mesa decorada com um arranjo de bolas coloridas sobre a toalha vermelha e verde de franjas douradas e com carinhas de Papai Noel bordadas. Tentando ser mais precisa, o detalhe significativo dessa lembrança não diz respeito aos talheres e pratos levemente desarrumados a denunciarem a pausa para a foto em meio ao almoço de Natal, nem mesmo a água na boca diante da imensa tigela de porcelana repleta de castanhas portuguesas prontas para serem devoradas.

Trinta e oito anos se passaram desde a performance xamânica de Kãñïpaye-ro, boa parte dos quais levei chegando e saindo de tantos lugares, um atrás do outro, e a vida toda carregando comigo um nome que não inventei. Enquanto a castanheira faz parte da vida Araweté, como faz parte a caça do jabuti, e porque faz parte da vida na terra um lugar celeste onde uma folhagem frondosa os deuses untam de urucum e fazem brilhar, a Castanheira, na minha vida, ocupa o lugar de um nome que me deram, a expressão de uma aliança em família. Descendente de imigrantes empurrados ao Brasil pela fome no final do século XIX, esta família é também um dos galhos de uma árvore plantada em solo colonizador.

Trinta e oito anos se passaram desde a performance naquela tribo ainda desconhecida para mim. Desde então, para além de nossas práticas e lendas, nossos muitos Natais, várias coisas se agitaram com o brilho de outros nomes e, com alianças menos estabelecidas e mais transversais, tantas outras coisas foram feitas. Aqui e ali, entre os acontecimentos marginais e sagrados de nossas vidas, lutamos pelas Diretas, saímos da ditadura, promulgamos uma constituição, destituímos um presidente, elegemos outros, protestamos contra a retirada de uma presidente do poder e seguimos nos empenhando, contra formas sofisticadas de exclusão, na batalha diária por uma democracia virtual que teima em não se atualizar para as minorias encarnadas na imensa maioria deste país. É nesse sentido que muitas coisas continuam estranhas. Nessa nossa forma de vida arrepiante, uma sensação assombrosa nos invade diante do que foi feito em Brumadinho, na floresta amazônica e na costa nordestina (citando acontecimentos de 2019); e continuou sendo feito (nos primeiros dias de 2020) em 
atentados contra indígenas e quilombolas no Mato Grosso do Sul, no Amazonas e no Maranhão. Além disso, o que dizer das milhões de vidas em risco, segundo declarações de relatores da ONU, por conta do que chamam de "políticas irresponsáveis"67 durante a pandemia do coronavírus?

Citar o que acontece por aqui parece importante para indicar o quanto estamos interessados em outras possibilidades de vida. No entanto, para mim, tal interesse não tem a ver com a possibilidade de algo bonito ou tranquilizador. Não no sentido banal de embotamento no bem-estar e na satisfação. Afinal, algumas experiências de contato são mais difíceis de ser enfrentadas que outras.

Tão difíceis quanto promissoras.

Tão promissoras quanto abissais.

Assim, reunindo esses conjuntos ecléticos de experiências artístico-pensantes, desestabilizadoras do modo de imaginar no Ocidente, este estudo começa pretendendo distender horizontes para a crítica de literatura e artes. Para avançar em suas contribuições, pretende instrumentalizar tal crítica com uma orientação epistemológica e metodológica importada do universo ameríndio.

$\mathrm{O}$ "Canto da castanheira” faz parte desse universo e é também um modo mágico de ver o mundo em que o ato de ver encontra-se submetido a um modo que excede o nosso ver e o nosso saber. Na beirada alucinatória dessa experiência, nesse lugar de enunciação impensável e incompreensível, aquilo que contamos como certo em termos de distinção entre céu e terra parece estar em disputa. Neste momento, volta a ecoar em mim, insidiosa, a máxima "uma coisa é uma coisa, outra coisa é outra coisa". Volta a ecoar esta simplificação na qual se apoia o nosso imaginário ocidental, na tentativa de encaixar em nossas mentes uma imagem de mundo que certamente não se presta à complexidade de mundos e de viventes. É nesse sentido que o "Canto da castanheira", nesse nosso modo redutor de pensar, não satisfaz o nosso imaginário. Assim, se de um lado, distanciados que estamos dos Araweté, olhamos para o seu mundo e vemos um céu mitológico, uma terra exótica, de outro lado, o canto xamanístico nos responde com um jogo sofisticado de vozes poéticas. Esse jogo me pega de surpresa e me levanta

67 Disponível em: <https://noticias.uol.com.br/colunas/jamil-chade/2020/04/29/relatores-da-onudenunciam-governo-por-colocar-milhoes-de-vidas-em-risco.htm>. 
a seguinte questão: tratar-se-ia de um jogo potenciamente infinito de quasidade de céu e de terra? Escolho aqui assumir a perplexidade dessa encruzilhada e tomar o quaseacontecimento como ponto de partida.

\section{5.}

\section{Histórias que vale a pena contar, ler, viver}

O contar com sentido de narrar é um modo de conhecer. O modo de conhecimento de mundos buscado pela arte passa pela relação que se estabelece com acontecimentos e pela imaginação de acontecimentos ao modo do quase. Nesse sentido, a ideia de que as histórias de quase acontecimentos são aquelas que vale a pena contar é colocada por Viveiros de Castro no âmbito da transcriação etnofilosófica que faz das formas de vida ameríndias ${ }^{68}$.

A possibilidade de se pensar a arte nos termos dessa espécie de tradução recriadora vem animando os estudos de muitos pesquisadores que, destacando-se por um desejo de renunciar a perspectivas antropocêntricas, manifestam interesse no pensamento ameríndio ${ }^{69}$.

No âmbito desses discursos, a quasidade desempenha papel importante. Pensando-a como potência, ela é o impulso imediato na força com a qual se apresenta, já foi dito, o mundo mágico do "Canto da castanheira", entre céu e terra. Pois então, tomando este objeto díspare como ponto de partida, esta tese pretende colaborar para as discussões sobre a quasidade em suas distintas operações, especialmente respondendo à ideia de permeabilidade mútua e alternância de posições para que se evite cair no domínio dos referentes identificáveis, na suposta vida em que a linguagem é mero instrumento. Promovendo, portanto, o quase contágio de pontos de vista parciais. Servindo-se (os pontos de vista) uns aos outros, e uns dos outros: cada um se transformando em operador da análise do outro.

\footnotetext{
${ }^{68}$ VIVEIROS DE CASTRO, Eduardo. A morte como quase acontecimento. In: Café Filosófico. TV Cultura/CPFL: 2009. Disponível em: 〈http://www.cpflcultura.com.br〉. Acesso em: 4 jun. 2020.

${ }^{69}$ Cito aqui algumas obras que, com diferentes ênfases, ilustram essa tendência recente de estudos: NODARI (2012); NODARI (2015); NODARI (2018); FALEIROS (2012); CESARINO (2011); e CESARINO (2013).
} 
Ler o quase assim pode abrir caminhos para um modo de pensar destotalizante e desierarquizado que acontece a partir de multiplicidades rizomáticas em diálogos e devires entre si. Dito de maneira um tanto rápida, a noção de rizoma se diferencia da noção de raiz - absolutamente fundamental para o pensamento platônico - , esta que implica em verticalização, verdade, originalidade e, principalmente, fixação de sentidos e de conceitos, numa tentativa de legitimar determinadas visões de mundo para invalidar outras. Por outro lado, a noção de rizoma, elaborada por Deleuze e Guattati, evoca de imediato uma antilinhagem. Ou seja: o rizoma "é estranho a qualquer ideia de eixo genético ou de estrutura profunda (...). Uma das características mais importantes do rizoma talvez seja a de ter sempre múltiplas entradas" ${ }^{70}$. Tal horizonte justifica o modo de incursão proposto aqui: para seguir adiante insistindo em novos modos de aproximar imaginação poética aos modos de viver e de pensar dos índios e pensando que o perspectivismo ameríndio nos convoca a buscar uma visão dos mundos possíveis indígenas em um horizonte ampliado, o das multiplicidades rizomáticas:

(...) tratar-se-ia aqui de um devir lateral interno ao mito, que o faz entrar no regime da multiplicidade, estilhaçando-o em fragmentos de uma rapsódia tão infinita quanto esparsa sobre os quase-acontecimentos: as anedotas, os boatos, a fofoca, o folclore familiar e aldeão, as historietas cômicas, os incidentes de caça, as visitações de espectros, os sonhos maus, os sustos repentinos, os presságios... Esse é o elemento de um mito menor, o mito como registro e instrumento do simulacro, da alucinação e da mentira. ${ }^{71}$

Opto, portanto, por uma incursão que contemple conexões transversais entre experiências artístico-pensantes e que implique deixar reverberar a força de interlocuções parciais, com ênfase na indeterminação de eventualmente encontrar outras formas de vida. Nas histórias que vale a pena contar, essa tensão é que vale a pena ser lida/vivida.

Daí que eu possa dizer que, como espaço de tensão teórico-inventiva, a arte vive de quase-acontecimentos. Nesta perspectiva e neste ponto do percurso, esta pesquisa se deixa atravessar pela seguinte interrogação: em que se apoia o que acontece nesse

\footnotetext{
${ }^{70}$ DELEUZE, G; GUATTARI, F. Introdução: Rizoma. In: Mil platôs: capitalismo e esquizofrenia. Tradução de Ana Lúcia de Oliveira, Aurélio Guerra Neto e Célia Pinto Costa. v. 1, 2. ed. São Paulo: Editora 34, 2011. p. 49.

${ }^{71}$ VIVEIROS DE CASTRO, Eduardo. Metafísicas canibais. São Paulo: Cosac Naif, 2015. p.196.
} 
quase? Quase-acontecer não é um não-acontecer: é um modo de acontecer. E o quase dessas relações incorpora dois sentidos conexos entre si, indicados por Alexandre Nodari no verbete “Como", publicado no Dicionário crítico da revista Sopro: o de uma aproximação ontológica, sem que um afastamento infinitesimal possa efetivamente ser superado; e o da acepção etimológica da palavra que se apoia no como se (do latim quam si). Já na Antiguidade tardia, existe uma aplicação técnica do quase. Chega-se a ela pelo valor central conferido a palavra hoion ("quase" em grego) pelo filósofo Plotino (205-270 d.C.) e utilizada por Nodari. No entanto, trata-se aqui de recusar a linha de pensamento grega desse como se em benefício de um sim, mas. É nesse sentido que a quasidade nutre um modo artístico assimilado pela linguagem tomada como forma de vida ${ }^{72}$ e não como sistema em perpétuo equilíbrio.

Assim, vão se revelando as texturas da quasidade. A quasidade encontrada em manifestações artístico-pensantes são de uma fonte com a qual se pode pensar a dimensão conceitual da arte e o imaginário conceitual que ela mobiliza. Com seu valor mítico, onírico e metamórfico, fazeres artísticos tornam-se capazes de desestabilizar todo um quadro conceitual e uma forma de vida. E mais: nos dão a possibilidade de nos surpreendermos com potencialidades poéticas, imagéticas, filosóficas e antropológicas. Por isso, insisto que uma das maneiras de nos deixarmos surpreender é investigar vínculos entre experiências imaginativas de quem vive "segundo o mito" e de quem vive nisso que chamamos de Ocidente, no sentido cunhado por Nancy:

Pode-se adicionar, a título de contestação: não podemos mais pensar em termos de "mundo" nem de "sentido" as experiências anteriores ou exteriores em relação ao Ocidente. Isto não quer dizer que seja simples traçar os limites desse "Ocidente" ("Ocidente" não é algo que simplesmente tenha começado no século VII a.C., na Grécia...); e inclusive tampouco significa que possamos indicar alguma coisa ou alguém um tanto exterior ao "Ocidente" sem estar todavia encerrado nele (ainda enquanto "Ocidente", convertendo o mundo em "mundal", já está implícito que subverter essa partição entre exterior e interior é dizer essa distinção entre "mundos" que nos parece configurar o mundo). Mas isto pelo menos quer dizer que, embora não possamos simplesmente conceber o "outro", tampouco temos mais motivos que apóiem pensá-lo simplesmente como o "mesmo". Digamos em relação a um dos maiores paradigmas de toda a nossa cultura: daqueles que vivem ou têm vivido segundo o mito, nós não

\footnotetext{
${ }^{72}$ Para explorar a noção de linguagem como forma de vida, este estudo busca a contribuição do pensamento de Wittgenstein. Em termos wittgensteinianos, "imaginar uma linguagem é imaginar uma forma de vida" (WITTGENSTEIN, 2008, § 9).
} 
podemos dizer que sua experiência seja uma modulação ou uma modalização do "sentido do mundo". Pois não sabemos em que sentido eles vivem um "mundo" e um "sentido". ${ }^{73}$

A experiência de imaginar com o corpo, como veremos, desempenhará papel importante para um pensar pós-humano - em meio à mundialização do mundo que é o nosso acontecimento, como reconhece Nancy —-, experimentando a existência de sujeitos atravessados por inúmeras forças culturais e naturais.

\section{6. Imagine Platão}

Adiante ficava Siracusa e agora, mesmo sendo nem sempre possível encontrar a expressão adequada para os problemas; ora caminhando de ideias em ideias ora descrevendo certezas imutáveis; agarrado ao bem em si e apegado ao saber por palavras sem imagens que acreditava dominar à perfeição; seus pés riscam o chão do barco. Sim, usando sandálias, está sentado encarando o mar logo antes de o sol nascer. São momentos de contemplação ávida do mar neste que é o seu segundo dia na embarcação. De qualquer forma, não havia nada para se ver. Nada demais, ele sabe, mas é que essas viagens têm sido tão cansativas a ponto de excederem qualquer possibilidade de compreensão. Dito assim fica até trivial, mas para quem vive escrevendo diálogos e acaba vendo tudo sempre pelo mesmo ângulo, na situação em que está, devassando o tedioso da viagem e no adiantado da vida, que é a maneira de dizer quando a idade deixa de ser só encantamento; agora, velho e solitário, desprotegido do sossego da Academia, seus olhos empapuçados tentam não bocejar, curvados sobre si mesmos,

\footnotetext{
${ }^{73}$ Da tradução para o espanhol: Se puede agregar, a título de contra-prueba: ya no podemos pensar más en términos de 'mundo' ni de 'sentido' as experiencias anteriores o exteriores um relación con Occidente. Esto no quiere decir que resulte simple trazar los confines de este 'Occidente' ('Occidente' no es algo que sencillamente haya comenzado um el siglo séptimo antes de Cristo, um Grecia...), e incluso tampoco significa que podamos indicar alguna cosa o alguien en tanto exterior a 'Occidente' sin estar todavía encerrados en él (aun cuando 'Occidente', convirtiendo el mundo en 'mundial', ya esté aplicado a subvertir esta partición entre exterior e interior, es decir, esta distinción entre 'mundos' que nos parece configurar el mundo.) Pero esto al menos quiere decir que, si bien nosotros no podemos plantear simplemente lo 'otro', tampoco tenemos más motivos que apoyen pensado sencillamente como lo 'mismo'. Digámoslo en relación con uno de los paradigmas mayores de toda nuestra cultura: de aquellos que viven o que han vivido según el mito nosotros no podemos decir que su experiencia sea una modulación o una modalización del 'sentido del mundo'. Pues nosotros no sabemos en qué sentido ellos viven um 'mundo' y um 'sentido'. (NANCY, 2003, p. 8).
} 
tentam aprender a sacrificar as necessidades, os medos e o desejo de cair no sono. E por se sentirem meio incompetentes nem encontram uma receita para insistir e toda essa experiência vira algo como uma escuridão discreta, uma penumbra nuançada com clarões. Olhando assim, é um clarão feito centelha que se acende na alma.

Querendo passar da exaustão, no ponto em que procura o céu, encontra o marco divisório de uma zona limítrofe. Vista de longe, essa linha não parece especial mas em nenhum outro lugar é tão visível e, com a aparição dos primeiros raios de uma manhã de verão, ela é real como nenhuma outra. Ergue a cabeça e quando se levanta para olhar melhor percebe o chão escorregadio e se curva. Esfrega com o polegar a tabuinha revestida de cera muito bem protegida sob os braços cruzados e empalidece.

Como não caiu, fechou os olhos por um momento e quando fez que ia novamente se sentar, mas tinha de ficar em pé para admirar melhor, daquela maneira, trêmulo, encarando o mar, começou a quem sabe delirar um pouco. A ideia de não mais controlar o pensamento incomoda intensamente. Incomoda tanto que, cambaleando, não sabia mais o que era um pensar e um dizer filosóficos. Então por que não faz algo diferente? Por que não pensa em como fazer os outros sentirem o que está sentindo? Porque não pode ser verdade, diriam, sei lá, de alguma maneira, diriam que não teria sido assim, de um modo até surpreendente para quem visse de fora, talvez tivesse algo a ver com as circunstâncias, aquela rajada de vento quente e asfixiante. Move os lábios sem emitir nenhum som como se seu corpo inteiro suplicasse a uma misteriosa força que insistia em fazer algo acontecer, fazê-lo ver e relatar. Formular uma outra escrita ainda. É que todo esse seu esforço para pensar diferente ia além das forças de que ele dispunha. E a condenação em palavras escritas das palavras escritas lhe enchiam de um medo de cair no ridículo.

Poucos centímetros adiante do nariz, pedaços de sentenças, começos e finais... flutuando. Impensáveis são essas visões que lhe vêm à cabeça e se multiplicam na tentativa de encontrar alívio num diálogo qualquer. Sim, seria necessário um diálogo inteiro ou um verdadeiro tratado para contar isso que está vendo. E por falar nas surpresas e mistérios do mundo, quando algo enfim aconteceu, ele não estava preparado. E deu no que deu. Olhou na direção em que supunha estar Siracusa e viu que, de fato, vinham pelas ondas contra a corrente uma multidão de viventes, 
incontáveis, desses que moram nos mares e que seu corpo miúdo em plena vastidão helênica ainda não conseguia nomear. Fica olhando para fora do barco essa ausência de qualquer coisa em escala humana. Fica olhando um tempão que dura a distância daqui até o dia em que a vida pudesse ser menos vulnerável. Nesse dia, quando sua liderança espiritual estivesse consolidada, por gerações e gerações, campos de conhecimento os mais diversos seriam estimulados a se referir aos tais bichinhos como moluscos, medusas, mexilhões, ostras, caranguejos, algas, plânctons, cardumes de peixes assim minúsculos, nadando no entorno do barco ou boiando na sopa marítima. Um tanto desorientado vê aparecerem aos poucos, depois aos montes, encherem toda a extensão do mar, nadando juntos sem, no entanto, se roçarem. O grupo se entretinha consigo mesmo, indo e vindo, trazendo imagens nítidas até onde o pensamento corta essas imagens. Lembra que nem sabe nadar e se pergunta se seus pulmões teriam força quando de repente já se vê imerso naquela sopa que é como se fosse um daqueles banquetes que adquirem a forma de um dia feliz, impressionante.

Era dessa maneira que o poeta encarava o mar? Quer dizer, tem pensado bastante nisso, o que será que encontra o poeta ao se deparar com um peixe de um cardume na superfície desse mar de lugares comuns? Sempre se pergunta o que é que encontra o poeta ao se deixar estranhar com alguma coisa no dentro-fora dele, fazendo-se atravessar por imagens, será que ele precisa de uma realidade atormentada, pontiaguda e quase paralela para imaginar seus jogos pueris de associações improváveis entre palavras ocas?

Sim, ele poderia ser feliz num banquete como aquele, era nisso que pensava e tentava se concentrar em alguns desses pensamentos mas preferiu deixar essas questões para depois já que melhor aqui, com o mar, porque incrível, mas incrível mesmo, como se não bastasse a bem-aventurada existência, é propriamente não viver para deixar-se conduzir por esse caldo, deixar-se levar, devagar e suave, e então ser trazido de volta pelas ondas quando, de um momento para o outro, algo ainda mais esquisito turva a visão, transformando a sopa na qual ele acabara de mergulhar em uma nuvem baixa sobre a água com ele dentro dessa nuvem. Além de tudo, embora a penumbra fosse realmente verdadeira, a textura granulosa no contato com as mãos soava falsa e exagerada. 
Quando pensou que já não enxergava mais nada, no instante seguinte, tapando a boca como quem segura um espirro, ou uma risada, acredita ver uma quelone. Enquanto observa ela se aproximando, maravilhado, ele quer saber de onde veio essa criatura cujo casco cintila na superfície com o brilho do sol já nascido. É que ela era diferente. Era diferente daquela ninfa preguiçosa que um dia, convidada para as bodas de Heras e Zeus, fora transformada em tartaruga como castigo por não ter comparecido à festa.

Ela pousa o olhar sobre o seu e faz com que ele veja algo como um corpo estranho. Um corpo como que assinalando uma ameaça em um dos orifícios do nariz da quelone. Enganchados um no outro, o corpo estranho com seu formato cilíndrico e a ninfa cujo casco podia passar por algum tipo de casa com a qual fora jogada por Hermes em um rio como parte do castigo dos deuses. Casco se jogando contra a carapaça do barco e a quelone impossivelmente agitada, com seus braços em formato de pá, faz gestos de quem lança um pedido de socorro.

$\mathrm{O}$ vigor com que ela movimentava os braços fez ele notar que havia, em tudo que ela não falava, uma dor silabada em sua mudez e nos seus olhos. E olhava, olhava muito para ele. A quelone engalfinhada com a morte. E a cada giro no redemoinho da corrente o corpo cilíndrico se enroscava ao rosto dela. Um rosto enrugado fazendo como que uma careta de medo. Ele hesitou se devia sair dessa nuvem. Sem querer e sem poder impedir, lá ficou, por quê, não sabia, ficou lá olhando de volta. Ela que um dia fora condenada ao silêncio no mito agora golfava sangue. Ele que tivera vontade de rir com essa espécie de diálogo incomunicável agora sentia náusea e uma incandescência invadindo o cérebro. É que pensar em sofrer é pior que o sofrimento. Parecendo que nunca mais ia respirar, seu peito pula e sacoleja. Um suor gelado desce do crânio, escorre dos cantos dos olhos pelas laterais do nariz, uma certa estranheza escorrega pelo pescoço, percorre o corpo e faz melarem as mãos.

O mundo apresenta muitos lados não-vistos. Mas não havia nada de tão artificial que pudesse ser tão cruel. Não se lembrava de ter visto algo assim. Algo que fosse um fragmento talvez decisivo ou que se identificasse com os tempos que corriam. Não havia nada parecido, nada como um objeto que pudesse ser de qualquer um ou de ninguém nesses tempos. Se não havia nenhuma razão no meio disto que estava vendo, ora, então o que estava imaginando? Seja lá o que for se intrometendo em um dos 
orifícios do nariz da quelone marinha, seja lá o que for, ele tenta se desvencilhar da imagem. Tenta se desvencilhar por se imaginar como sendo a dor que a quelone sentia e que ele via com tanta nitidez. Poderia contar a vida dessa dor por muitos amanheceres, uma dor calada que não sabe dizer a ninguém onde dói. A mão dela estava fria e, de um modo tão fantasista, ele se viu como a dor que insistia entre as coisas que pensava e aquilo que pensava não era mais um mero instrumento a permitir o desígnio das coisas. Havia ali uma fratura, da maneira mais vil, como a quebra de uma confiança depositada nele, como se fosse ele, a um só tempo, monstro e humano.

Ao que parece, pois, entre imaginar-se como sendo a monstruosidade que faz parte da dinâmica invisível do mundo, querendo reparar desde já todo o dano que a supremacia de um pensamento poderia provocar, e imaginar-se a dor de uma vida agora em perigo; percebendo o absurdo dessa experiência, entre monstruosidade e dano, embora não soubesse ao certo o que poderia ser, nada era bom nessa tentativa de formular uma escrita a partir de um corpo que reverbera um acontecimento, algo como se fosse a proposta sinuosa de um caminho irresistível.

Embaraça os pés no chão do barco. Os lábios tremem. Sentiu as pernas escurecerem de tanto habitarem essa ideia e, tolhidas, fraquejarem com tudo que isso tem de poético e perturbador. Ele passou o dia todo olhando o mar. Naquele dia, havia feito a maior descoberta, até ali, embora no fim parecia que nada havia acontecido. 


\section{3 \\ Uma teoria Yanomami do imaginar}

3.1.

Outra imaginação?

"Tudo que é imaginado tem, existe.

Sabia que tudo que é imaginado existe e é e tem?

Pois é".

Estamira

Na cosmologia Yanomami, o imaginado possui legitimidade ontológica e o imaginar não se confina aos limites superiores do pescoço. Embaralham-se, no imaginar, o pensado e o vivido, o espírito e o corpo, natureza e cultura. Experimentar a radicalidade desse embaralhamento, é estranhar um universo de referências deslocadas dos sentidos de vida, pensamento, corpo, espírito, natureza e cultura, no âmbito de nossas antropocêntricas estruturas sociais: estas que quase bloqueiam o que afronta nossos hábitos de ver. Digo quase porque, à margem deste conjunto de pressupostos, pelo menos dois traços da experiência de imaginar no universo ameríndio - os quais entrevemos com incômodo e dificuldade - nos acenam com um convite, sugerindo algumas direções para pensarmos realidades alternativas no campo das relações entre vida e imaginação. São aspectos que nos expõem ao ponto em que todo um universo se desorganiza conforme a dinâmica artística de um imaginar com o corpo e o estado de quasidade desse imaginar. Tais aspectos nos permitem talvez ver como as multiplicidades (em detrimento de totalidades hierárquicas) e a conexão transsensorial de componentes de alteridade (em detrimento de elementos estáveis dominantes) podem romper com o modelo tradicional de pensamento ao tornar mais radicalmente porosa a relação entre vida e imaginação. É nesse sentido também que se tornam capazes de deslocar normas e padrões instituídos pelas variáveis dominantes do mundo de que participamos. Por isso, importam especialmente para esta pesquisa. 
Interessa ao presente estudo que mundos, vida e imaginação se interpenetrem e operem em variações de si mesmos, tornando-se capazes de dispersar focos de identidades estáveis e fixas, abrindo brechas para modos inventivos de produção de pensamento. Se assim for, a um só tempo imaginado e vivido, pode o saber estabelecido seguir em outras direções: as páginas que, entre nós, guardam saberes registrados em sequências de caracteres alfabéticos, podem, por exemplo, virar "peles de imagens",74 — é assim que nossas páginas são descritas pelos Yanomami. Entre as "peles de imagens" que se encontram na fronteira nebulosa da imaginação com a vida, está $A$ queda do се́u, livro do etnógrafo Bruce Albert escrito a partir das palavras contadas pelo narrador David Kopenawa.

O livro, hoje bem conhecido, trata de temas diversos, tais como o surgimento do mundo, as relações entre etnias indígenas e os brancos; os contatos com a Funai; políticas de saúde desastrosas e genocídio; direitos da floresta; soberania e domínio geopolítico; contato fantasmagórico e nefasto com setores do agronegócio, da mineração e da especulação fundiária; além de testemunhos proféticos e inúmeros depoimentos autobiográficos a partir de episódios ocorridos durante o processo para se tornar um xamã Yanomami. Apesar de se ocupar de acontecimentos que recebem um tratamento antropológico, o livro é descrito por Eduardo Viveiros de Castro, no prefácio, também como "um onirismo especulativo, em que a imagem tem toda a força do conceito"75. Não é, portanto, só o discurso da antropologia sobre os povos ameríndios que está em questão, mas um modo outro de vivência da produção de pensamento. Não só o exercício etnográfico para ser assimilado por uma comunidade de antropólogos. Não se trata enfim de afirmar propriedades constitutivas ou critérios de inclusão classificatória. Mas se trata de privilegiar campos relacionais antidualistas e em processo. Entre David Kopenawa e Bruce Albert, surge o desafio de imaginar o inimaginável.

\footnotetext{
${ }^{74}$ KOPENAWA, David; ALBERT, Bruce. A queda do céu. Tradução de Beatriz Perrone-Moisés. São Paulo: Companhia das Letras, 2015. p. 610.

75 Ibid., p. 40.
} 


\section{2.}

\section{Kopenawa em sonho}

A partir do sobrevoo de experiências vividas/imaginadas por David Kopenawa, das 729 páginas da edição brasileira, na tradução de Beatriz Perrone-Moisés, brotam imagens verbais e uma multiplicidade de acontecimentos. Volto-me, antes de tudo, aos sonhos de Kopenawa.

Na infância, ele sonhava estar sendo sonhado. Esse, aliás, era o mundo dentro do qual ele existia durante o sono quando criança. E como era bonito esse mundo que tornava visível qualquer coisa imaginada. Mundo bonito e assustador, ainda na infância ele tinha dificuldade de compreender um tipo de sensação ou força que costumava experimentar em sonho, e de apartar a novidade de emoções do ambiente dolorosamente vivo que adentrava seu corpo enquanto dormia. No meio da noite, começava com uns murmúrios, até que esses murmúrios miudavam, fraquejavam as vozes e então elas iam crescendo de novo, arrastadas, ressoavam misteriosas e aumentavam ao máximo. De um segundo para outro, ele estava cercado por gritos ensurdecedores e por penugens de um branco ofuscante girando numa nuvem massuda ou num enxame luminoso em que luzes piscavam e mudavam de cor.

Por isso nunca dormia tranquilo. Quando o sol se levantava no peito do céu, sentia o corpo ainda sonolento, enjoado. As sensações da volta na atmosfera diurna intensificavam a desorientação do corpo. Embora fizesse um esforço grande para se acalmar, sentia muito medo do sonho da noite anterior e não podia compreender o que acontecia dentro de si. Ficava surpreso e satisfeito quando conseguia se pôr de pé, andar... Seu corpo deixava escapar que a visão de seres assustadores já era a dos espíritos xapiri ${ }^{76}$ que vinham até ele, que o faziam ver a imagem do céu se quebrando, lançavam ruídos estrondosos e, por isso, tanto o assustavam durante o sono. Os xapiri o levaram, depois de adulto, a querer beber o pó de yãkoana para se tornar aquilo que lhe permitiu existir em outro plano, o da experiência xamânica.

\footnotetext{
${ }^{76}$ Não abordarei ainda os espíritos xapiri nesta passagem: retornarei a eles na sequência do capítulo.
} 
Quando foi ver, já estava definitivamente entregue àquela experiência e quando isso aconteceu ele sentiu que não falava mais todas as palavras que dizia, mas as palavras é que falavam por ele. Sua vontade própria não mais atuava, não havia necessidade de atuar. Foi sua vontade que dera início àquilo tudo mas, já no início, às apalpadelas, ainda tateando, começou a perceber o que é que o atraía nessas palavras e nas histórias que contavam, que chamavam por ele. Eram todas palavras de Omama $^{77}$ e dos xapiri.

Já adulto, Kopenawa decidiu entregar ao antropólogo Bruce Albert as palavras surgidas no tempo do sonho, entregá-las para que fossem feitas o que chama de peles de imagens. Ele e Bruce Albert que encheria peles de papel com o desenho de suas palavras, por algum tempo, não conseguiam compreender bem o que diziam um para o outro. No princípio, o antropólogo foi para Kopenawa um estranho, alguém que falava uma língua de fantasma quando foi viver com a sua gente. Nessa época, algumas palavras de um para o outro faziam sentido, mas a vida toda dessas palavras, não.

O primeiro encontro entre eles aconteceu durante um reahu, a grande festa de aliança entre comunidades, ensinada por Omana e realizada para colocar no chão da casa, em estado de esquecimento, as cinzas dos falecidos. No reahu, entre os que habitam a região do médio rio Catrimani, ao longo de cerca de uma semana, as noites são animadas. As gentes se reúnem na praça central, na penumbra, ao redor da fogueira onde as chamas iluminam os rostos que ouvem atentos os cantos e assistem à suntuosa dança apresentada pelos xamãs. O clima de alegria e entusiasmo contagia a todos: respeitados anciãos e mais jovens, donos da casa e convidados acampados em pequenos refúgios na floresta.

Naquela noite, o guerrear dos pés batendo o chão cadenciava a pressa da friagem da madrugada que se aproximava. Em meio à turbilhonante nuvem de poeira que subia, Kopenawa pôde ver o estranho ao seu lado. Ele ainda era jovem quando aconteceu esse encontro com o antropólogo Bruce Albert. Dali em diante, haveria apenas uma amizade e uma confiança crescentes entre os dois, com aulas improvisadas, a princípio em um português lento, mal pronunciado, que era a maneira possível àquela altura de se dirigirem um ao outro e de passar ao Bruce alguns

\footnotetext{
${ }^{77}$ Sublinho apenas que Omama é o demiurgo da mitologia Yanomami.
} 
rudimentos de saber xamânico. Depois disso, se reencontrariam na sua região natal, em Toototobi, onde o antropólogo viveu por seis meses, comendo da mesma comida e rindo junto até que a língua Yanomami pegou em Bruce e, mais tarde ainda, na casa coletiva de seu sogro, onde o antropólogo passou a se hospedar regularmente. Desde então, Kopenawa esteve ocupado, andando de um lado para outro, por tantas línguas e nações, alargando seus caminhos fora da floresta e tratando sua gente. Desde então, prometeu lutar contra os garimpeiros comedores de terras; contra o pensamento deles que é o mesmo dos seres maléficos que põem a morte no sopro de vida; contra o sopro da fumaça de epidemia xawara que rasga pedaços inteiros do peito do céu; contra a cobiça do povo da mercadoria que retalha o céu com furor.

\subsection{1. Sobre imaginar o mundo ameríndio}

Cabe, neste ponto, destacar o seguinte: se, como quer Estamira, tudo o que se imagina "é, existe, tem", imaginar o mundo ameríndio equivale, em certa medida, a cruzar barreiras ontológicas - ir a outro mundo. Viveiros de Castro faz recorrentemente afirmações como esta: "[o] encontro ou o intercâmbio de perspectivas é um processo perigoso, e uma arte política - uma diplomacia"78, uma vez que, em oposição ao multiculturalismo ocidental, as diferenças de corpos de que pretende dar conta o multinaturalismo ameríndio perfazem a diferença de mundos.

Põe-se assim em questão a nossa forma habitual de imaginar o que é imaginar. Nesse sentido, no presente estudo, a escolha do relato de Kopenawa não é de modo algum gratuita. Se o que podemos imaginar sempre existe, interessante notar que, entre viver e imaginar mundos que não se deixam nunca racionalizar completamente e nunca chegam a ser o mundo dos humanos ou o mundo dos não humanos, é através da experiência xamânica de Kopenawa que uma narrativa nublada ou um nublado da narrativa transita entre as verdades invisíveis dos acontecimentos em A queda do céu. Esse nublado da narrativa se deixa iluminar pela imaginação. Quando ativamente

\footnotetext{
78 VIVEIROS DE CASTRO, Euardo. A inconstância da alma selvagem e outros ensaios de antropologia. São Paulo: Cosac Naify, 2002. p.358.
} 
incluída na performance do pensamento, é a imaginação que faz acontecer algum saber transformador.

Tal experiência xamânica joga o tempo todo com a possibilidade de adentrar a existência de um outro e de tornar sujeito o não humano. A narrativa carrega consigo o pensamento imaginativo e o traz para dentro da experiência vivida. Dali avista-se um saber desconcertante à vaidade do saber antropocêntrico, o de que o céu possa cair e, a partir dessa queda, apesar do nosso paralisante estupor, possa o planeta acabar destruído:

Gostaria que os brancos parassem de pensar que nossa floresta é morta e que ela foi posta lá à toa. (...) Quem sabe assim eles queiram defendê-la conosco? Quero também que os filhos e filhas deles entendam nossas palavras e fiquem amigos dos nossos, para que não cresçam na ignorância. Porque se a floresta for completamente devastada, nunca mais vai nascer outra. ${ }^{79}$

A floresta é posta como multiplicidade viva e é essa multiplicidade que determina o destino do que acontece aos mundos gerados em processo. Porque a floresta não pode acabar. Sendo assim, no contexto de uma interação singular com a floresta, imediatamente A queda do céu inquieta o leitor com sua potência. Uma potência capaz de mostrar o que ainda parece ser um total mistério para aqueles que não veem: que, no mundo onde se vive para comprar coisas, a floresta desenhada por Omama vai ser cortada ou queimada e, ao virar moeda, corre o risco de desaparecer junto com esse mundo.

Trata-se de uma escrita que faz tremular um feixe de relações indeterminadas que nos atravessa e que é operativo, articulando mundos como seus motores. Um feixe de relações entre o mundo do "eu" e o mundo do "outro". E é este o meio estratégico e singular pelo qual as palavras de Kopenawa são oferecidas a Bruce Albert: "E, mais tarde, dirá a seus filhos: 'Estas palavras escritas são as de um Yanomami, que há muito tempo me contou como ele virou espírito e de que modo aprendeu a falar para defender a sua floresta" $" 80$.

\footnotetext{
${ }^{79}$ VIVEIROS DE CASTRO, 2002a, p. 65.

${ }^{80}$ KOPENAWA; ALBERT, 2015, p. 64.
} 


\subsection{2.}

\section{A sede móvel do imaginar}

Esse punhado infinito de relações pode ajudar a pensar mundos que não têm uma moldura tão rígida e estão constantemente se redefinindo; aguçando, portanto, um deslocamento, ao sugerirem conexões em outros domínios. Advindos de domínios diferentes, acontecimentos se entrelaçam e se deixam tomar uns pelos outros, numa espécie de contágio. Muito embora não exijam convivência com habitantes de tribos remotas, promovem uma experiência de conhecimento desejante desses mundos, pondo-nos em movimento junto com ela e fazendo com que nos sintamos atraídos por esses acontecimentos através de uma profusão de atravessamentos. Desejo explorá-los.

Tal profusão refere-se ao privilégio reservado pelos ameríndios aos campos relacionais em processo. Os modos indígenas de pensar a realidade evocam o privilégio da relação em detrimento da substância com seus atributos fixos. Isto significa que pôr coisas em relação não é reconhecer um encadeamento substancial dado. É um jogo: “os sujeitos e os objetos são antes de mais nada efeitos das relações em que estão localizados e assim se definem, redefinem, se produzem e se destroem na medida em que as relações que os constituem mudam" ${ }^{81}$. Esse tipo de definição apresentada por Eduardo Viveiros de Castro pode ser lida como um traço da complexidade enunciativa de perspectivas presentes em A queda do céu. Essa complexidade envolve uma disposição xamânica para com a alteridade humana e não humana.

O xamanismo é um modo de apreensão de singulares acontecimentos demasiadamente tênues para serem percebidos como tais. O xamã transforma o que parecia demasiadamente tênue em campos relacionais feitos de surpreendente textura. A espessa e notável textura das relações vividas. A potencialidade desses campos relacionais inclui os deslocamentos, as transformações e as renovações dos modos de viver e de conhecer oriundos de um modo de imaginar em estado selvagem. Podem-se abrir aí outras possibilidades de pensar-dizer-viver-sentir; podem-se deslocar valores

\footnotetext{
81 VIVEIROS DE CASTRO, Eduardo. A Filosofia Canibal. Folha de São Paulo. São Paulo, 21 ago. 2005. Disponível em: <https://www1.folha.uol.com.br/fsp/mais/fs2108200509.htm>. Acesso em: 4 jun. 2020 .
} 
tácitos, inacessíveis à introspecção; podem-se afirmar singularidades contra a supremacia ocidental do pensamento do mesmo e do um.

A partir da arte de narrar do xamã, o seu exercício perspectivista, deparamos com mais possibilidades de encontrar o surpreendente: aquelas capazes de nos levar, senão para longe de nós, ao menos capazes de nos fazer estranhar um modo de pensar e de viver. Como observa Viveiros de Castro, "as coisas mudam e, com elas, as possibilidades de pensamento; muda a ideia do que é pensar, e do que é pensável" 82 . Tentando seguir essas possibilidades, em um primeiro momento do percurso de $A$ queda do céu não se pode deixar de experimentar a curiosa sensação de ser exposto ao jogo entre um imaginar e um estar sendo imaginado, como quem entra em um sonho e é sonhado. Como ressalta Helena Martins, em suas reflexões sobre o filme Adeus à linguagem (2014) - citando Jorge Luís Borges que, por sua vez, é citado por Godard (subvertendo-o) na sequência em que é mencionado o encontro entre nós (os ditos ocidentais) e os índios apaches:

Enquanto no filme se diz "esta manhã é um sonho, cada um deve pensar que o sonhador é o outro" [cette matinée est un rêve, chacun doit penser que le rêveur c'est l'autre], Borges diz, na tradução fiel de Davi Arrigucci Jr., "[s]e esta manhã e este encontro forem sonhos, cada um dos dois tem que pensar que o sonhador é ele". Na versão de Godard, cada lado deve dizer: é você o sonhador; e, na de Borges, o sonhador sou eu. Mas, se nos dois casos, é um sonho a própria manhã do encontro, então, o que está em disputa, nas duas versões é, afinal, qual dos sonhos é aquele que vigora (sabendo-se sonho ou não). ${ }^{83}$

Nisso que chamamos de Ocidente, quando acontece o encontro entre mundos, tende a vigorar um mundo dos humanos separado de um mundo dos não humanos, ou seja, entre nós, imagina-se um só e mesmo mundo, segundo um ponto de vista antropocêntrico. Por sua vez, quando inserida no contexto ameríndio, a sede do imaginar é móvel, isto é, a experiência do xamã, no encontro entre "eu" e "outro", nega essa oposição de mundos como oposição. Tal renúncia xamânica desestabiliza nosso próprio imaginar — este que concede historicamente enorme privilégio ao que

\footnotetext{
${ }^{82}$ VIVEIROS DE CASTRO, 2015, p. 97.

${ }^{83}$ MARTINS, Helena. Resta saber se o não-pensamento contamina o pensamento: citação e invenção em Adeus à Linguagem de Jean-Luc Godard. In.: Cadernos de Literatura Comparada, n. 41, p. 171190, 2019. p. 184.
} 
chamamos de humano. É também por aí que a narrativa xamânica desenvolvida em $A$ queda do се́u insinua-se como das mais instigantes.

\section{3.}

\section{Imaginar espíritos}

Em A queda do céu, portanto, as regras de organização do mundo antropocêntrico beiram a desestabilização e o relato xamânico, em seu movimento antinarcísico, estabelece vínculo com o leitor a partir de imagens muito singulares. Refiro-me a encontros narrados por Kopenawa. Como já descrito aqui, ele narra infindáveis perturbações que o faziam falar e chorar durante o sono, na infância. Nessa época, lembra-nos o xamã-narrador: "meu ventre caía de medo" ${ }^{84}$.

Já adulto, quando foi trabalhar para os brancos no posto da Funai de Demini, no sopé da Montanha do Vento, seus sonhos assustadores não tinham parado. E então experimentalmente o sogro soprou o pó de yãkoana em suas narinas. Kopenawa lembra que isso não aconteceu num período de festa reahu porque os xapiri preferem o silêncio para se apresentarem pela primeira vez. Foi quando ele sentiu que o chão devia estar se movendo embora não houvesse sensação de movimento, apenas esse silêncio exigido pelos xapiri, um terrível e completo silêncio lá fora, além de um sol bem alto no céu. O sogro pediu que ele se agachasse e, com a destreza de um grande xamã, começou a soprar boas quantidades de pó em cada uma de suas narinas, com um tubo de madeira palmirinha horoma. Soprava com força e recomeçou várias vezes. Então, de repente, a imagem Yãkoanari, que é o nome do pai da yãkoana, bateu em sua nuca e o jogou para trás, no chão. Deitado, ele poderia ter dormido ali mesmo e talvez desmaiasse mas na verdade a yänkoana penetrava nele pelo nariz que é a entrada de sua casa de espíritos. Enquanto inalava, a yãnkoana era bebida através dele pelos espíritos que desciam em seus espelhos e, como ele e ao mesmo tempo que ele, entravam em estado de fantasma.

\footnotetext{
${ }^{84}$ VIVEIROS DE CASTRO, 2015, p. 89.
} 
Durante um período comprido, ele se submeteu a esta e a outras sopradas. Sem noite nem dia, existiu num vazio em que seus olhos morreram, o tempo não passava, não havia tempo naquele limbo. Era um vazio cheio de surpresas, prontas a se revelarem com o impacto de um encontro que se avizinhava. Depois que voltava a si, ele se agachava de novo na frente de seu sogro e continuava aproximando as narinas, seus braços mostravam longos arranhões que invocavam o urucum com o qual desenharam seu corpo. Seus braços estavam doloridos como depois que se enfia o dedo numa dessas tomadas que os brancos põem em suas casas amontoadas na cidade. Sua cabeça doía muito, sentia vertigem.

No entanto, era assim. Já que iria viver como xamã, o mundo desconhecido dos xapiri era tudo o que ele queria descobrir. A yãnkoana penetrava nele pelo nariz e o contato da sola de seus pés com o chão ficava cada vez menos firme. O chão cedia sob seu peso. Seu corpo entregava-se a essa maciez como alguém que anda sozinho na floresta. Porém, uma vez distraído, demorou um pouco a sentir a presença de alguns xapiri que, passando a seu lado, carregaram com eles sua imagem para as costas do céu. Havia lá uma clareira onde ele deveria pisar com cuidado. O chão era um grande e brilhante espelho. E os xapiri estavam ali, era possível sentir a força deles, especialmente os que vinham das lonjuras e os que agiam com mão firme cortando a língua de quem só emitia palavras de fantasma substituindo-a pela imagem sólida de suas próprias línguas, dentes e vísceras. Fizeram isso com ele, dando-lhe a conhecer o desenho da floresta.

\subsection{1.}

\section{Sobre o encontro com os xapiri}

O que gostaria de destacar, neste ponto: ao beber o pó de yãkoana, o xamã vê sua forma de vida se esvanecer e a multidão de vozes dos xapiri se aproximar para o confronto que o levará ao cruzamento de mundos. "Vejo tudo isso em sonho porque, tornado fantasma com a yãkoana durante o dia, o meu interior se transformou. Senão 
eu não poderia falar assim" ${ }^{85}$. É como se fosse próprio desses encontros o narrador ir se entrechocando constantemente com alteridades, como partículas que se chocam e, a cada vez que se chocam, mudam de consistência, fazendo com que a própria relação mude.

Tais encontros desviam o foco narrativo e desapontam a expectativa do leitor no que diz respeito ao reconhecimento e à sequência de desdobramentos, apontando então para o que as narrativas não dizem diretamente. No entanto, a leitura é levada adiante através da viagem proposta pelo enredo na beirada alucinatória da experiência xamânica. De alta significação poética, a narrativa torna palpável, em algum nível, aquilo que permanece esquivo, ao tomar especialmente os espíritos xapiri como uma constelação de forças infinitas que adentra o corpo de Kopenawa. Quando se comunica com os xapiri, o xamã Yanomami chega a ficar tão próximo deles que é como se o seu corpo estivesse partido entre esse mundo e um outro mundo. Para além das milhares de palavras trocadas entre Kopenawa e os xapiri, compartilham-se gestos, olhares, angústias, alegrias, um jeito de vestir, um jeito de dançar, um jeito de comer, um jeito de imaginar.

Ainda assim, os xapiri permanecem estranhos ao leitor e as histórias narradas por Kopenawa estão cheias de choques de perspectivas em todos os níveis. Invisíveis mas não menos corpóreos, portanto, mesmo de apreensão trabalhosa, os xapiri permanecem infinitamente sedutores embora, já na primeira parte do livro (intitulada “Devir outro"), sejamos incapazes de afirmar exatamente o que o xamã chama de corpo e/ou de espírito nisso que se apresenta como imensurável:

É por isso que eu gostaria que eles ouvissem minhas palavras através dos desenhos que você fez delas; para que penetrem em suas mentes. Gostaria que, após tê-las compreendido, dissessem a si mesmos: 'Os Yanomami são gente diferente de nós, e no entanto suas palavras são retas e claras ${ }^{86}$.

Ficamos em suspenso. O que dizer então daquilo que não pode ser inteiramente compreendido por si mesmo, muito embora produza diferença e participe do modo como se relacionam mundos, vida e imaginação? De início, como uma maneira de nos

\footnotetext{
${ }^{85}$ VIVEIROS DE CASTRO, 2015, p. 86.

${ }^{86}$ KOPENAWA; ALBERT, 2015, p. 64-65.
} 
lançarmos num campo aberto de possibilidades presentes e ausentes no que se lê, podese até tentar identificar os modos de ser desses corpos-espíritos conforme algumas propriedades constitutivas ou certos critérios de inclusão classificatória no sentido específico de corpo e/ou de espírito. Um leitor de tribo platônico-aristotélica tem suas razões para tentar seguir por esse caminho. Afinal, a ortodoxia filosófica de tradição ocidental nos leva a adotar a premissa de que todo corpo é algo físico e todo espírito, metafísico. Porém, sendo impossível fazer com que correspondam ponto a ponto com a nossa cosmologia, é preciso reconhecer que, na cosmologia indígena, corpo e espírito surgem, para nós, como algo difícil de identificar. De outro lado, surgem como algo que, em se tratando da nossa relação com o mundo, nos desidentifica.

As forças infinitas não podem ser perdidas de vista e a resposta possível a essa imensurabilidade é a experimentação. A experiência de colocar em relação corpos e espíritos pode nos servir como um primeiro exemplo desse desafio. Tal experiência requer ainda uma disposição para arranhar a palavra "corpo" e a palavra "espírito" com muitas aspas, se quisermos explorar a proposta de um vínculo entre humanos e não humanos. Dentro desse amplo espectro de possíveis conexões parciais em que cada mundo amplia o que podemos pensar do outro, uma tensão entre diversos sentidos de corpos e de espíritos salta aos olhos e nos puxa para perto de pensamentos contemporâneos que têm como problemática central a questão do perspectivismo e das subjetividades humanas e não humanas.

A partir do perspectivismo ameríndio, na versão que lhe dão Eduardo Viveiros de Castro e Tânia Stolze Lima, é notório que os mundos possíveis que a imaginação conceitual indígena projeta são diferentes dos nossos. Para eles, corpos que, ao seguirmos a árvore de Porfírio, contamos como inanimados ou animados mas não racionais, podem se tornar pontos de vista pensantes, subjetivos e interlocutores em relações com os chamados "humanos", que a árvore de Porfírio registra como animais racionais. No modo de pensar e de viver dos indígenas, não há uma localização própria do "humano", sendo esta uma categoria pronominal e sendo o "eu" uma espécie de feixe de relações. Tomemos, por exemplo, a distinção entre humano e animal: “(ser) animal é uma condição que não pode ser concebida na primeira pessoa; ele é uma forma da consciência de outrem, ao passo que a consciência de si envia diretamente ao 
humano" 87 . Nossas distinções humano-animal e animado-inanimado, compreendidas que são como distinções substantivas, colapsam diante desse modo pronominal de ser e de viver. Em outras palavras, tudo é gente para si mesmo, há uma continuidade metafísica entre humanos e não humanos. Porém, como se trata de perspectivismo, Viveiros de Castro chama atenção para o problema que se apresenta com "tudo" e "gente":

"Tudo é gente, mas tudo não pode ser gente ao mesmo tempo, uns para os outros. Quando dois seres, duas espécies diferentes, entram em contato, constata-se a presença de uma tensão constante, latente ou patente, em torno da posição de sujeito, um combate pelo ponto de vista" $" 88$.

Em A queda do céu, o marcador enunciativo "ser humano" — isso que, entre nós, tomamos não como um marcador enunciativo, mas uma marca substantiva de poder serve para nos lembrar algo importante: na cosmologia indígena, todos os seres dotados de consciência ou agentividade, incluindo seres enigmáticos e imortais, como os xapiri, reconhecem a si mesmos como gente, o que significa que o ser é movimento e gente não é uma condição específica da humanidade, assim como a concebemos: "[a] quem cabe a posição de humano aqui? - essa é sempre a questão que se põe quando um indivíduo confronta um emissor estranho de afectos e de agentividade" ${ }^{\nexists 9}$. Para os ameríndios, humanos e não humanos são tipos identitários sempre abertos a se desfazerem em afetos, prontos a captarem as forças constituintes da configuração multiposicional do cosmos indígena, com sua capacidade de proliferação de agências, a partir da ação xamânica.

Por envolver esses emissores estranhos, o confronto com os xapiri - sendo capaz de desnortear - é também arriscado, abrangendo ação e performance por parte do xamã. A centralidade do comportamento expressivo do xamã David Kopenawa inclui a multiplicidade aberta e instável de sentidos e de perspectivas dos xapiri para o pensamento e a vida Yanomami, como fica evidente à medida que se avança na leitura

\footnotetext{
${ }^{87}$ LIMA, Tânia Stolze. O dois e seu múltiplo: reflexões sobre o perspectivismo em uma cosmologia Tupi. In.: Mana, Rio de Janeiro, v. 2, n. 2, p. 21-47, 1996. p. 29.

${ }^{88}$ SZTUTMAN, 2008, p. 234.

${ }^{89}$ VIVEIROS DE CASTRO, 2015, p. 171-172.
} 
do capítulo "Os ancestrais animais". Já nesse título, pode-se reconhecer a marca de uma aliança longínqua com os protagonistas da história que está sendo contada e, no primeiro parágrafo, é mencionado o fato de que os animais em questão são antepassados do povo Yanomami, os chamados "yarori”: "É esse o seu verdadeiro nome. Vocês os chamam 'espíritos', mas são outros"90.

Originariamente tudo era humano, dizem muitas das narrativas míticas indígenas. Com o tempo, alguns foram perdendo suas possibilidades humanas para deixarem de sê-lo. Esse modo de compreensão é generalizado entre os indígenas, de acordo com a cosmologia perspectivista assim como é transcriada por Viveiros de Castro e Stolze Lima. Afora o fato de sugerir um modo de pensamento adverso à teoria darwiniana, a narrativa xamânica é o relato daquilo que não vemos. Portanto, aquilo que não racionalizamos porque a razão de ascendência grega já nos proibiu há muito tempo de dizer que seja verdade aquilo que não vemos. Ao contrário do que preconiza nossa mitologia ocidental, os antepassados na forma de vida ameríndia são "seres cuja forma, nome e comportamento misturam inextricavelmente atributos humanos e não humanos: entre os ameríndios os mitos contam como os animais perderam os atributos herdados ou mantidos pelos humanos"91. Quando Kopenawa diz que os antepassados Yanomami continuam existindo no nosso tempo como seres invisíveis, ele está se posicionando como xamã ao reconhecer nos não humanos atuais sua humanidade invisível.

\section{4.}

De volta a isto: imaginar com o corpo

Ali, onde dizemos "espíritos", Kopenawa nos apresenta a seguinte ressalva: "mas são outros". Que outros são esses? No capítulo intitulado "Multinaturalismo", do livro Metafísicas canibais, Eduardo Viveiros de Castro destaca que:

\footnotetext{
${ }^{90}$ KOPENAWA; ALBERT, 2015, p.111.

${ }^{91}$ VIVEIROS DE CASTRO, 2002a, p. 354-355.
} 
esses seres a que damos desajeitadamente o nome de "espíritos" são o testemunho de que nem todas as virtualidades foram atualizadas, e que o turbulento fluxo mítico continua a rugir surdamente por debaixo das tranquilas descontinuidades aparentes entre tipos e espécies ${ }^{92}$.

Mais adiante no texto, o antropólogo afirma que "o perspectivismo ameríndio conhece então no mito um lugar geométrico onde a diferença entre os pontos de vista é ao mesmo tempo anulada e exacerbada" 93 . Sobre o uso da palavra "espírito" por nós, talvez recorramos a ela por ser mais fácil do que tentar ver algo diferente. Sobre as diferenças que se sobressaem na narrativa de Kopenawa, destaca-se ainda "utupë”: noção Yanomami para "imagem”.

Todos os seres possuem uma imagem primordial, mítica, como uma vitalidade imagética indissociável de seus corpos, visível somente aos xamãs que a convocam ("fazem dançar" 94 ). Os xapiri, por sua vez, são seres-imagens muito singulares e podem ser descritos "como humanoides minúsculos paramentados com ornamentos e pinturas corporais extremamente luminosas e coloridas" 95 . Kopenawa nos conta que, como parte do processo de iniciação, ao beberem o sopro do pó de yãkoana, os xamãs são olhados pelos xapiri. Para ver, os xamãs precisam ser vistos e examinados pelos xapiri que, por sua vez, dispõem do corpo xamânico para falar e agir.

A exposição desse pensamento de multiplicidades toma os xapiri como uma constelação de forças, apontando-os como desencadeadores do processo de iniciação xamânica que se constrói segundo uma dinâmica contínua de diferenciação dinâmica esta interventora do processo inventivo e antropofágico de viagem ao mundo de outras subjetividades e de retorno para contar histórias.

Tal processo efetivamente opera mediante o cruzamento de fronteiras corporais. Cruzar fronteiras não é aqui passar de uma região a outra do ser, mas antes experimentar a radical mobilidade de perspectivas. Viver, por assim dizer, a "imanência do inimigo", quando efêmeros encontros se dão segundo um diálogo

\footnotetext{
92 VIVEIROS DE CASTRO, 2015, p. 59.

${ }^{93}$ Ibid.

${ }^{94}$ KOPENAWA; ALBERT, 2015, p. 610.

${ }^{95}$ Ibid.

${ }^{96}$ VIVEIROS DE CASTRO, 2002a, p. 265.
} 
entre espécies sob o modo de um ingresso no tortuoso, pela proeza da imaginação. Os xamãs ocupam o lugar de interlocutores ativos nessa prática.

Entre os Yanomami, os xamãs só ganham existência na relação com os xapiri e estes, por sua vez, existem a partir do ponto de vista xamânico. Ambos participam da narrativa em $A$ queda do céu, a partir do jogo entre a experiência xamânica e o ato de voltar para contar a história. Um jogo entre o mesmo e o outro. E é o tornar-se fundo "daquele" que faz "este" vir ao primeiro plano. Tem-se ali uma situação em que tais formas de vida estão ancoradas na dinâmica das relações e os encontros com essas alteridades não são apreendidos em primeiro lugar intelectualmente; pois "o ponto de vista está no corpo" 97.

Para descrever o fato de ser o corpo a dimensão marcada pelos indígenas no que diz respeito às funções semióticas, Viveiros de Castro cita o exemplo de que, no universo ameríndio, nos primeiros tempos da colonização nunca se duvidou que os europeus tivessem alma e, sim, que outros espíritos tivessem um corpo semelhante ao seu:

Em poucas palavras, a práxis europeia consiste em "fazer almas" (e diferenciar culturas) a partir de um fundo corporal-material dado (a natureza); a práxis indígena, em "fazer corpos" (e diferenciar espécies) a partir de um continuum sócio-espiritual dado "desde sempre" - no mito, precisamente (...) A suposta indiferenciação entre os sujeitos míticos é função de sua irredutibilidade constitutiva a essências ou identidades fixas, sejam elas genéricas, específicas ou mesmo individuais. ${ }^{98}$

Nessa passagem, Viveiros de Castro nos lembra que o mito ameríndio irá propor o ser não fechado em si mesmo, mas ser-com e ser-para, enquanto acontecimento aberto a todos os devires, enquanto vida ou modos de estar no mundo. Uma outra passagem de "Os pronomes cosmológicos e o perspectivismo ameríndio" permite avançarmos um pouco mais na elusiva compreensão do lugar reservado ao corpo na forma de vida ameríndia:

\footnotetext{
${ }^{97}$ Id. Os pronomes cosmológicos e o perspectivismo ameríndio. In.: Mana, v. 2, n. 2, 1996. p. 128.

98 VIVEIROS DE CASTRO, 1996, p. 38-58.
} 
O que estou chamando de "corpo", portanto, não é sinônimo de fisiologia distintiva ou de morfologia fixa; é um conjunto de afecções ou modos de ser que constituem um habitus. Entre a subjetividade formal das almas e a materialidade substancial dos organismos, há um plano intermediário que é o corpo como feixe de afecções e capacidades, e que é a origem das perspectivas. ${ }^{99}$

Os sentidos que os procedimentos xamânicos produzem nunca se elevam acima da própria experiência corporal. Dessa maneira, em primeiro lugar, é preciso dizer que, para os ameríndios, a imaginação está ligada menos ao que acontece a uma pessoa em especial que a uma capacidade de multiplicação de agência pelos muitos mundos. A imaginação encontra-se no cerne da narrativa adotada por Kopenawa e é um dos princípios que regem a performance incorporada.

Talvez já esteja claro aqui que "[a]penas os xamãs, pessoas multinaturais por definição e ofício, são capazes de transitar entre as perspectivas, tuteando e sendo tuteados pelas agências extra-humanas sem perder sua própria condição de sujeito"100. Com a capacidade de ver simultaneamente segundo perspectivas incompatíveis, um xamã torna-se o sujeito capaz de fazer a leitura de todos os modos de ser no seu aspecto humano, os modos como cada um se coloca enquanto interlocutor. Humano não é aqui, repitamos, o nome substantivo de uma espécie mas uma condição pronominal.

O perspectivismo ameríndio nos mostra que o ponto de vista é um modo de ver irredutível à mente do xamã. Um modo que vai desaguar em um feixe de afecções e capacidades. O corpo consiste nesse feixe de afetos com a capacidade de ocupar o ponto de vista dos espíritos xapiri (mas também o ponto de vista dos bichos, das montanhas, dos rios...) e essa capacidade carrega o modo de um imaginar com o corpo. Nesse imaginar, existe um "ver como" que não se pretende tão somente um modo de dizer, mas também um modo de viver. A forma de vida ameríndia está o tempo todo atravessada por essa experiência:

Vendo-nos como não humanos, é a si mesmos que os animais e espíritos veem como humanos. Eles se apreendem como, ou se tornam, antropomorfos quando estão em suas próprias casas ou aldeias, e experimentam seus próprios hábitos e características sob a espécie da cultura: veem seu alimento como alimento humano (os jaguares veem o sangue como cauim, os mortos veem os grilos como peixes, os urubus veem os vermes

\footnotetext{
${ }^{99}$ VIVEIROS DE CASTRO, 1996, p. 38-58.

${ }^{100}$ Id., 2002a, p. 397.
} 
da carne podre como peixe assado etc.), seus atributos corporais (pelagem, plumas, garras, bicos etc.) como adornos ou instrumentos culturais, seu sistema social como organizado identicamente às instituições humanas (com chefes, xamãs, ritos, regras de casamento etc. $)^{101}$

Os exemplos citados referem-se a algumas das inúmeras ocorrências no universo ameríndio desse "ver como". Mais um:

Quando nos encontram na floresta, os seres maléficos në wãri nos consideram como suas presas. Veem-nos como macacos-aranha e a nossos filhos como papagaios. É verdade! É o nome que nos dão. De modo que nunca poderíamos sobreviver sem a proteção dos xapiri, que os në wãri temem como inimigos ferozes. ${ }^{102}$

Os xamãs possuem essa capacidade de transitar entre diferentes estados de "ver como" na medida em que acessam a "subjetividade formalmente idêntica à consciência humana"103 dos seres cosmológicos em geral. No lugar onde deveria estar um animal (ou xapiri), eles se imaginam na roupa de animal. A noção de roupa, uma das verdades da forma de vida ameríndia, varia de acordo com cada espécie. A roupa se torna transparente aos xamãs, o que lhes permite, ao mesmo tempo, ver o invisível e experimentar a antropomorfia espiritual dos seres que a roupa esconde. No entanto, vale observar que esse "esconder" não se dá nos termos de "dentro" e "fora", como acontece nos pressupostos ocidentais de vida e pensamento, mas ocorre no sentido de dar a ver para além da "aparência enganosa dos seres e dos fenômenos"104.

Os xamãs entram assim numa espécie de turbulência visível-invisível contida numa névoa de virtualidades sobre a qual atuam para, a partir de então, construírem imagens imbricadas ao mundo de outrem. Trata-se de um imbricamento corporal, considerando-se que o que muda é o mundo que eles veem e que se torna desajustado em relação ao mundo que habitam e a uma forma de vida habituada que é puxada para todos os lados.

Funcionando então como um ato de transferência vital, a experiência do xamã (de imaginar com o corpo) é um dos modos de a sensibilidade ameríndia acessar o

\footnotetext{
${ }^{101}$ Ibid., p. 350-351.

102 KOPENAWA; ALBERT, 2015, p. 610.

${ }^{103}$ VIVEIROS DE CASTRO, 2002a, p, 351

${ }^{104}$ KOPENAWA; ALBERT, 2015, p. 615.
} 
mundo de outrem. Frequentemente o xamã se expõe a um pensado e um vivido à maneira de outrem para, por exemplo, em certa medida, apresentar a seu próprio mundo a encenação de um exterior naquilo que já é interior, de um distante naquilo que já é próximo, de um por vir naquilo que já é chegado, de um outro naquilo que já é mesmo. É justamente nesse ponto (da intercessão xamânica com o mundo de outrem) que a narrativa acontece como um caso especial de imaginação que vem à tona nessa experiência tornando possível a especulação de um por vir naquilo que já é chegado. Apesar da não inclusão desse modo de escrita na atual constelação de acontecimentos científicos tradicionais, apesar de não se adequar a este ou aquele critério de inclusão classificatória a uma ciência que tudo quer racionalizar, apesar disso, tal escrita de fato possui uma riqueza de pensamento no sentido de possibilidades de vida. Enquanto parte de uma experimentação desconstrutora de mensagens, esses textos são ricos sobretudo no sentido de permitir consistência a um imaginar com o corpo a partir do percurso especulativo.

Sugere-se aqui um motivo potente para fazer conexão entre mundos que se desestabilizam e corpos desestabilizados. O imaginar com o corpo sensifica isso que é tanto vivido quanto pensado. Pode-se dizer assim que a inusitada aproximação com os xapiri, a partir da performance xamânica, implica a capacidade de sonhar mundos que não se dirigem apenas ao plano da compreensão de significados:

O sonho (mari) é considerado um estado de ausência temporária da imagem corpórea/essência vital (utupë) que se destaca do invólucro corporal (siki) para ir para longe. O sonho xamânico (designado como "o valor de sonho dos espíritos", xapiri pë në mari) ocorre quando os xapiri viajam levando a imagem do sonhador. ${ }^{105}$

É como penetrar na misteriosa ondulação das regiões de sentido. Afinal, o que pode acontecer em estados nos quais nossas formas mais racionais e conscientes de compreensão beiram ceder não ao simples colapso, mas antes a outras ainda insondáveis vias de entendimento? A partir dessa dimensão de um imaginar com o corpo, o xamã projeta rumo ao desconhecido, o esotérico, onde são conquistadas sensibilidades que desafiam o enfadonho senso comum. A partir dessa dimensão, os

105 KOPENAWA; ALBERT, 2015, p. 616. 
limites da linguagem são afrontados, quando é composta uma escrita inventiva que se recusa a admitir que humanos e não humanos não possam se comunicar. Com a culminação desse processo inventivo em A queda do céu - que, avizinhando-se do real, não se reduz às condições de possibilidade do real — , a narrativa xamânica se afasta do mundo dado de maneira suficiente para afetar o leitor a partir da experiência de corpo. Esse avizinhamento gera uma realidade que constituiria já uma atualização, provocando no leitor uma inquietação com distorções conceituais e equívocos perceptivos. Tal experiência pode ser aquela em que, por assim dizer, o corpo vibra quando em contato com as palavras e nos conduz a um entendimento sensível do mundo em sua singularidade radical. A queda do céu faz emergir ativamente o que é imaginado com o corpo ao nuançar paradoxalmente aquilo ainda não inscrito no registro do inteligível.

\subsection{1. Imaginar corpos em caminhos flutuantes}

Kopenawa afirma que as imagens dos animais que os xamãs fazem dançar não são as dos animais de caça: "são de seus pais, que passaram a existir no primeiro tempo. São, como disse, as imagens dos ancestrais animais que chamamos yarori" ${ }^{\prime 106}$. Ao afirmar que um animal é outro que sua imagem, Kopenawa remete a uma lembrança de si diante dos espelhos de um hotel onde dormiu na cidade:

Eu estava sozinho diante deles mas, ao mesmo tempo, tinha muitas imagens idênticas espalhadas neles. Assim, há um só nome para a imagem da anta xama enquanto xapiri, mas existem muitíssimos espíritos anta que chamamos de xamaripë. É assim com todos os xapiri. Há quem pense que cada um é único, mas suas imagens sempre são muito numerosas. Apenas seus nomes não o são. São como eu, de pé diante dos espelhos do hotel. Parecem únicos, mas suas imagens se justapõem ao longe sem fim. ${ }^{107}$

Esses "espelhos da cidade" de que o xamã fala têm por sua vez um sentido adjacente no contexto mítico-xamânico de A queda do céu. Trata-se da expressão usada por

\footnotetext{
${ }^{106}$ KOPENAWA; ALBERT, 2015, p.117.

${ }^{107}$ Ibid.
} 
Kopenawa: são espelhos que brilham - "não são espelhos para se olhar"108. Bruce Albert explica por meio de nota:

Os espelhos industriais são chamados mirena (mire para os Yanomami ocidentais), um termo que se distingue do que designa os "espelhos" (mireko, mirexi) dos xapiri embora partilhe com ele a mesma raiz (mire). Mirexi designa, além disso, os areais misturados com mica que brilham nas águas dos igarapés de montanha. $X i$ significa "luz, radiação, emanação", como em wakara xi, "luz do dia" ou poripo xi, "luz do luar"109

É neste sentido que se pode dizer que os "espelhos" dos xapiri são eles mesmos uma superfície que reflete a luz e não reproduz imagens. Os espelhos dos xapiri são antes um caminho flutuante que uma superfície fixa e aderente como o são aqueles nas paredes do hotel na cidade, conforme se pode depreender do exemplo evocado pelo xamã. E esses caminhos são usados pelos espíritos xapiri quando se deslocam pela terra executando sua dança de apresentação. Com a apresentação da dança dos xapiri, as palavras xamanísticas de Kopenawa nos mostram a possibilidade de nos aproximarmos de uma floresta de cristais brilhantes que são a pura intensidade luminosa onde formas de vida múltiplas se justapõem entre diferentes ontologias.

É por isso que se pode dizer também que há uma contiguidade entre o sentido de um espelho-xapiri e o de um caminho flutuante onde acontece a performance visível somente aos xamãs: "os espíritos estão o tempo todo indo e voltando e correndo com alegria por eles, produzindo uma brisa fresca" ${ }^{110}$. Se esse imaginar com o corpo nos apresenta um pensado e um vivido promissores no sentido de trazer a esse mundo alguma diferença, presumamos uma constelação de forças imagéticas em que os próprios fantasmas do nosso tempo se vejam hoje implicados.

Gostaria de explorar aqui o nosso contexto histórico. Presumamos então que um acontecimento xamânico seja arrastado para dentro da nossa forma de vida e se estabeleça, a partir daí, a possibilidade de comunicação entre incomunicáveis. Seguindo essa ótica, pergunto: e se nos encontrássemos de repente com os chamados espíritos xapiri descendo do céu sobre grandes e luminosos espelhos?

\footnotetext{
${ }^{108}$ KOPENAWA; ALBERT, 2015, p. 119.

${ }^{109}$ Ibid., p. 621.

${ }^{110}$ Ibid., p. 121.
} 
Há algo de enlouquecedor nessa hipótese, mas vale a pena imaginar: numa segunda-feira de agosto de 2019, por volta das três e meia da tarde, milhões de habitantes de São Paulo olham para o céu e se confrontam com uma paisagem de escuridão brilhante. A crescente ocorrência de queimadas no bioma Amazônia, em choque com uma frente fria vinda do sul do continente, traz à maior cidade do país as cinzas de milhares de árvores que estão virando fumaça. Sim, aquilo que os Yanomami chamam de xapiri trouxe ao Brasil dito moderno e ocidental um aviso pronunciado pelo bafo incendioso da floresta.

Eduardo Viveiros de Castro vê os xapiri como um "intervalo entre dois corpos quaisquer, mais do que um não corpo ou um corpo nenhum"111. Na medida em que seriam o intervalo entre o não-corpo e o corpo-nenhum, essas imagens excedem seu caráter puramente icônico, o que lhes permite a indexação de "afetos característicos daquilo de que são a imagem sem, por isso, parecerem com aquilo de que são a imagem"112. Existem portanto como índice, reflexo de uma experiência a exigir uma concepção que passa por uma relação de vizinhança por disparidade.

Segundo a tese de Viveiros de Castro, o fato de haver no transe xamânico "uma certa relação de vizinhança obscura entre o humano e o não humano, uma comunicação secreta que não passa pela redundância mas pela disparidade entre eles" "113, não permite uma mera representação que dê sentido ao mundo: "os xapiripë não se parecem com os animais, mas, no contexto mítico-xamânico, os animais se parecem com eles"114. Alfred Gell, para ilustrar a questão (que cito por intermédio de Viveiros de Castro), ao elaborar a ideia de agentividade como carga semântica ligada a imagens indiciais, evoca o exemplo do diplomata chinês: ele se parece com a China, mas, "em Londres, a China se parece com ele" ${ }^{115}$. A experiência xamânica, agindo através dos xapiri, acaba inventando ali um tipo de imagem representante que não é representação.

\footnotetext{
111 VIVEIROS DE CASTRO, Eduardo. A floresta de cristal: notas sobre a ontologia dos espíritos amazônicos. In.: Cadernos de campo: revista dos alunos de pós-graduação em antropologia social da USP. São Paulo: n. 14/15, 2006. p. 326.

${ }^{112}$ KOPENAWA; ALBERT, 2015, p. 325.

${ }^{113}$ Ibid., p. 326.

${ }^{114}$ Ibid., p. 325.

${ }^{115}$ GELL apud VIVEIROS DE CASTRO, 2006, p. 325.
} 
Sobre o fenômeno ótico de São Paulo, os fantasmas do nosso tempo então me perguntam: seria tal abertura para o outro (no mesmo) propulsora de uma experimentação político-cultural, político-científica, político-tecnológica? Com sua ajuda, poderia nosso pensamento vir a se tornar um dia sensível não obstante inteligível? Seja como for, a nuvem escura sobre a tarde de São Paulo não representa o dia como se fosse noite. Ali, não. Ali, também não é possível se agarrar a um modo de dizer para tentar dar sentido ao que aconteceu. Não meramente. Afinal, no que tem de mais inimaginável, aquela nuvem escura não é senão “intensidade luminosa”, para usar as palavras de Viveiros de Castro sobre os xapiri. Uma intensidade irrepresentável que evoca os legítimos representantes do povo da mata, detentores do conhecimento das palavras de Omama. Entre eles, a imagem në roperi:

A floresta não cresceu por si só, à toa, como eu disse. É seu valor de fertilidade në rope que a torna viva e lhe propicia sua abundância. Os nossos grandes xamãs me falaram a respeito disso muitas vezes e, desde que meus olhos sabem morrer sob o poder da yãkoana, eu também posso ver sua imagem, que chamamos në roperi. Ela é o verdadeiro dono da floresta e sabe ser generosa. No entanto, se resolver ir embora, nada mais crescerá, o solo ficará quente demais e a floresta logo passará a ter valor de fome. A pele da floresta é bela e cheirosa, mas se suas árvores forem queimadas ela resseca. Então, a terra se desfaz aos pedaços e as minhocas desaparecem. Os brancos sabem disso? Os espíritos das grandes minhocas são os donos do chão da floresta. Se forem destruídos, ele fica árido. Por baixo dele, aparece então uma terra vermelha, da qual só podem sair brotos de plantas ruins e capim ralo. Nós não arrancamos a pele da terra. Cultivamos apenas sua superfície, pois é nela que está a sua riqueza. Seguimos nisso as palavras de nossos ancestrais. ${ }^{116}$

Talvez uma das maiores diferenças entre o platonismo e a cultura ameríndia, no que diz respeito à visão como modelo da percepção e do conhecimento, seja que, no caso da cosmologia amazônica, trata-se de um modelo não representacional que toma a imaginação como dispositivo de conhecimento e de criação de sentido incorporado. A intensidade luminosa surge como esse elemento não representacional. $\mathrm{Na}$ perspectiva xamânica, a partir dos espelhos imaginados, o conhecimento é concebível. Assim os espíritos são vistos como pontos que não estão ali para reproduzir a imagem imperfeita de uma perfeição suprassensível, mas como rota de fuga exploradora de um

${ }^{116}$ KOPENAWA; ALBERT, 2015, p. 471. 
vínculo entre humanos e não humanos através do sonho. Portanto, rota de fuga criadora de uma comunicação por disparidade entre humanos e não humanos.

Os xapiri não se parecem com a nuvem escura mas, no contexto de inquietudes e interrogativas do nosso tempo - e neste experimento de leitura - , a nuvem escura carrega consigo uma intensidade luminosa. Indo um pouco mais além nessa correlação, o incontestável desse acontecimento é que, em meio a uma precisão deformante e de uma grandiosidade que não se pode deter, a escuridão torna visíveis fantasmas que ofuscam nossa existência e que se expressam nesta posição: de um corredor de fumaça sobre as luzes de São Paulo. Vêm avisar que a floresta está queimando e o céu vai cair.

Quem imaginaria? Valho-me dessa incontestabilidade para verificar, por este outro ângulo, que a narrativa de Kopenawa tanto não pode ser enquadrada nos moldes convencionais do gênero ficcional ou da literatura etnográfica acerca dos povos indígenas como confunde gêneros narrativos. Afinal, sem tentar dar-lhe a forma que lhe escapa, é interessante reconhecer que o livro tem relação com algo que se anuncia comum historicamente, mas que parece estar em via de alcançar na realidade o seu ápice: a sugestão de que os gravíssimos riscos e incertezas do nosso tempo têm a ver com a incapacidade de atentar para os perigos que assombram nossas vidas, incapacidade comprovada por um tipo de cegueira ou desmesura antropocêntricas. Como atestariam os xamãs, as relações entre mundos podem ser dolorosamente entrelaçadas. Por isso, não se trata simplisticamente de inventar um modo de dizer mas da possibilidade de inventar um modo de viver outro. Algo capaz de acenar com alguma alteração no funcionamento de nossa forma de vida, lá em suas esferas mais arraigadas e infrarreflexivas. Suponhamos enfim que tais relações possam abrir caminho para uma saída climática que se pretende buscar, encontrando outros mundos e conhecendo outros mundos, os outros que existem na nossa relação com as naturezas das coisas. $\mathrm{O}$ xamanismo se acha nesse registro.

\section{5.}

\section{Estado de quasidade}

Como várias vezes aqui mencionado, num mundo que não acomoda o entendimento de natureza única, o xamã tem trânsito entre as diferentes naturezas que 
se espalham por todo o cosmos indígena. Conforme tentarei expor a seguir, o como as relações com essas naturezas acontecem é uma questão de quase, antes de qualquer outra coisa. Se, no trânsito ontológico, o como inclui um imaginar com o corpo, este é um aspecto contributivo da experiência de quasidade que escapa ao pensamento como tal, ao mesmo tempo em que afeta o modo como ganha expressão, a partir do acesso às sensibilidades de outrem. Nesse contexto de vários mundos que não se reduzem a um só mundo, a circunstância xamânica é uma circunstância que envolve um risco de perda do próprio mundo ou do próprio modo de expressão. Em outras palavras, se os jaguares veem o sangue como cauim e os xamãs possuem a capacidade de transitar entre diferentes estados de "ver como", nessa dimensão onírica do pensamento, sangue é quase cerveja e cerveja é quase sangue - o mundo vacila no entre mundos.

A expressão do pensamento em estado de quasidade, além de envolver a dimensão onírica, requer uma atenção que situa o corpo na borda da metamorfose. Trata-se aqui da metamorfose própria das narrativas míticas ameríndias e das experiências xamânicas atuais.

As narrativas míticas estão cheias de episódios de transmutação de diferenças dadas pelas especificidades dos corpos. Claude Lévi-Strauss compreende esses episódios como sendo constituintes do próprio universo mitológico ameríndio. Na obra Mitológicas, sua análise relaciona os mitos metonimicamente por exemplos onde distinções mínimas produzem diferença, afetam personagens e a própria construção das narrativas que, por sua vez, se interpenetram. Em seu estudo, o antropólogo recombina mitos com outros mitos mostrando as transformações de uns nos outros e fazendo, ainda, uma aproximação entre os chamados contos de transformação e as narrativas ditas ocidentais.

Lembrei-me um dia destes das páginas de Mitológicas em que Lévi-Strauss escreve, por exemplo, que a narrativa do caçador "Monmaneki" lembra a de "Desventuras de cimidyuë" - ambos mitos Tukuna. Com o breve registro e neste ponto do percurso, gostaria de dizer que pretendo tão somente apresentar a força operatória do estado de quasidade de um imaginar com o corpo, do modo como o percebo, em contato com o regime de metamorfose mítica. Eduardo Viveiros de Castro assinala um ponto fulcral dessa metamorfose: 
(...) a questão de saber se o jaguar mítico, por exemplo, é um bloco de afetos humanos em figura de jaguar ou um bloco de afetos felinos em figura de humano é rigorosamente indecidível, pois a metamorfose mítica é um acontecimento ou um devir (uma superposição intensiva de estados heterogêneos), não um processo de mudança (uma transposição extensiva de estados homogêneos) ${ }^{117}$

Toda a orientação da noção de metamorfose na forma de vida ameríndia vem da doutrina das roupas animais aqui já citada: os indígenas falam dos corpos como roupas. Toda a ideia de corpo envolvida nesta doutrina depende, segundo Viveiros de Castro, "menos de o corpo ser uma roupa que de uma roupa ser um corpo"118. Tal experiência de imaginar com o corpo expõe a distância entre mundos possíveis. Deter-se sobre tal experiência nos faz reconhecer, nessa distância, algo de indiscernível. É possível assim experimentar uma roupa que é quase corpo:

As roupas de animais que os xamãs usam para viajar pelo cosmos não são fantasias, mas instrumentos: são semelhantes a equipamentos de mergulho, ou trajes espaciais, e não a máscaras de carnaval. A intenção ao vestir uma roupa de mergulho é ser capaz de funcionar como um peixe, respirar debaixo d'água, não se esconder sob uma estranha cobertura. Do mesmo modo, as "roupas" que, entre animais, cobrem uma "essência" interna de um tipo humano, não são um mero disfarce, mas equipamentos distintos, dotados dos efeitos e capacidades que definem cada animal. (...) Em resumo: não há dúvida de que os corpos são descartáveis e trocáveis e que por trás deles estão subjetividades formalmente idênticas aos humanos. Mas a ideia não é semelhante à nossa oposição entre aparência e essência; ela apenas manifesta a permutabilidade objetiva dos corpos, baseada na equivalência subjetiva de almas. ${ }^{119}$

Está em jogo portanto experimentar um encontro entre corpos que nunca estão prontos, íntegros, mas incompletos, parciais e inacabados. Quase corpos que vão se fabricando e cujas relações devem ser entendidas como uma indiscernibilidade por

\footnotetext{
117 VIVEIROS DE CASTRO, 2006, p. 323.

${ }^{118}$ Id., 2002a, p. 393.

119 No original: "The animal clothes that shamans use to travel the cosmos are not fantasies but instruments: they are akin to diving equipment, or space suits, and not to carnival masks. The intention when donning a wet suit is to be able to function like a fish, to breathe underwater, not to conceal oneself under a strange covering. In the same way, the 'clothing' which, amongst animals, covers an internal 'essence' of a human type, is not a mere disguise but their distinctive equipment, endowed with the affects and capacities which define each animal. (...) In short: there is no doubt that bodies are discardable and exchangeable and that 'behind' them lie subjectivities which are formally identical to humans. But the idea is not similar to our opposition between appearance and essence; it merely manifests the objective permutability of bodies which is based in the subjective equivalence of souls" (VIVEIROS DE CASTRO, 1998, p. 482).
} 
onde se movimentam os pontos de vista que podem ser lidos no entre da experiência xamânica com o ato de voltar para contar a história: pontos de vista que não chegam a se transformar mas que se deformam mutuamente.

Desse modo é que se entende o procedimento xamânico como o exercício perspectivista de um corpo que se abre para o outro no mesmo e que, tomado então por diversos atravessamentos, tenta ocupar um estado de véspera, um espaço limiar entre diferentes ontologias, uma quasidade — sem que, no entanto, jamais a distância possa ser totalmente superada. A quasidade, que não tem sentido em si mesma, é o modo de deslocamento nessas ocasiões singulares e o modo de apreensão nessa zona-entre. Nela, opera-se sob a lógica de uma comunicação insolvível, ou melhor, de efeito suspensivo mútuo: longe de se resolverem, as relações entre mundos são marcadas por absorção e ativação coexistentes de afetos. E é na turbulência da indiscernibilidade que a inventividade em estado selvagem se constitui.

Pela própria capacidade de experimentar a roupa dos xapiri (ver como: imaginar com o corpo), o xamã Yanomami transita no limiar entre as dimensões da animalidade e da humanidade, do natural e do sobrenatural, para, a partir daí, construir sua narrativa carregada de densidade sensível. Para Viveiros de Castro, mais importante neste discurso é "o funcionamento de uma poderosa imagística intensiva da cintilação e do reflexo luminoso, por um lado, e da divisibilidade-multiplicação dos espíritos, por outro" ${ }^{120}$. É por isso que a narrativa de Kopenawa nos apresenta a imagem luzidia dos xapiri, apresentando assim os limiares de uma corporalidade capaz de comportar e multiplicar grandes contrastes internos em formas de vida humanas e não humanas:

A imagem dos xapiri é muito reluzente (...). Suas cabeças são cobertas de penugem branca; emana deles uma luminosidade deslumbrante que os precedem por onde forem. É um ornamento que só eles possuem. Por isso os xapiri cintilam como estrelas que se deslocam pela floresta. Os lóbulos de suas orelhas são também enfeitados com caudais de papagaio e despojos de pássaros hëima si. Seus dentes são imaculados e brilhantes como estilhaços de vidro. Quando são pequenos demais ou se falta algum, eles os substituem por pedaços de espelhos que pedem a Omama para se embelezar. Alguns chegam a enfeitá-los com penas multicolores de pássaros sei si, como fazem os brancos com seus dentes de ouro. Outros possuem longos caninos, afiados e amedrontadores,

${ }^{120}$ VIVEIROS DE CASTRO, 2006, p. 331. 
com os quais dilaceram os espíritos maléficos. Outros ainda têm olhos atrás da cabeça! São espíritos das florestas longínquas. São mesmo outros. Assim é. ${ }^{121}$

Assim sendo, é pelo viés de uma latência entre o perceptível e o imperceptível sensível que ali opera a inventividade. Pelos incalculáveis movimentos dos xapiri onde a imagem é protagonista do enredo dessa história, o corpo xamânico empresta e toma emprestado formas de vida ao ativar uma miríade de agências nos mundos com os quais se relaciona.

Uma dessas agências faz o sentido de xapiri transbordar para a imagem de humanidade arcaica, tratando-se ali de uma imagem de antepassados que escapa à filiação e com a qual é possível formar uma aliança contranatureza. "São essas imagens os animais de caça de verdade, não aqueles que comemos! São como fotografias destes"122, afirma o xamã, desde que essas fotografias sejam "imagem corpórea" ou “essência vital, forma mítica primordial" ou até mesmo "eco, miniatura"123 dos animais de caça, isto é, uma questão de devir-espírito que é devir-imagem de quase humanos, os quase animais da floresta.

\section{6. Quasidade fantasmal}

Passo agora a perseguir ainda um pouco mais a força operatória dos quase animais da floresta, os xapiri, na narrativa de A queda do céu. Chamo aqui esta força de quasidade fantasmal.

Quando ficamos assim arrumados, carregam-nos para as costas do céu e lá nos depositam no meio de uma clareira, onde fazem sua dança de apresentação. O chão dessa clareira é um grande espelho salpicado de penugem branca que cintila com uma luminosidade ofuscante. É tudo ao mesmo tempo magnífico e apavorante. É nossa imagem que os xapiri levam desse modo, para consertá-la. Primeiro a extraem de dentro do nosso corpo, para depositá-la em seus espelhos celestes. Enquanto isso nossa pele, muito enfraquecida, queda-se estendida na praça de nossa casa, na floresta. Então os espíritos extraviam nosso pensamento e nossa língua, para nos ensinar a sua. Depois nos dão a conhecer o desenho da floresta, para que possamos protegê-la. Os xapiri são estupendos

\footnotetext{
${ }^{121}$ KOPENAWA; ALBERT, 2015, p.112-113.

122 KOPENAWA; ALBERT, 2015, p. 116.

${ }^{123}$ Ibid., p. 621.
} 
e resplandecentes. Parecem muito pequenos e frágeis, mas são muito poderosos. A partir de seus espelhos, revelam-nos a aproximação das fumaças de epidemia, dos seres maléficos da floresta e dos espíritos do vendaval ${ }^{124}$.

Os xapiri vêm de longe, provocam uma desorientação espacial e determinam o que acontece ao pensamento e à língua do xamã. Eles começam a extraviar pensamento e língua quando o corpo do xamã está estendido no chão da praça central sob efeito do pó de yãnkoana. Chamado sopro de vida, o pó de yãnkoana faz a pele do xamã (a roupa que se usa) ficar muito enfraquecida. Ao cercarem o corpo de Kopenawa, tornando sua pele enfraquecida, querem com isso consertar sua imagem de alguma maneira que permita ao xamã compreender o perigo por que passa a floresta. Querem comunicar esse perigo traduzindo-o ao modo da imaginação e, para isso, servem-se de componentes do meio indígena. Formulam então o desejo de proteção da floresta através de um desenho invisível desses componentes. Muito poderosos, convocam as imagens das fumaças de epidemia, dos seres maléficos e dos espíritos do vendaval. $\mathrm{O}$ xamã, por sua vez, não impede a ação dos xapiri nem refuta a aproximação do mundo não humano ao seu mundo: entrega suas narinas ao sopro de vida do pó de yãnkona. As narinas são a entrada de sua casa de espíritos. Essa é uma questão importante para os Yanomami: usam a expressão casa de espírito como sinônimo de peito do xamã. Mas o que casa de espírito colada no peito do céu tem a ver com peito do xamã? É apenas mais uma dentre tantas outras relações entre quase corpos na forma de vida Yanomami. O xamã inala a yãnkoana que é bebida através dele pelos xapiri que descem em seus espelhos e, como ele e ao mesmo tempo que ele, entram em estado de fantasma.

Algo como um choque de perspectivas decorre desse processo. Avista-se ali uma singularidade relevante. Conforme enfatiza Manuela Carneiro da Cunha, o xamã “observa sob todos os ângulos (...) como se abordasse um domínio desconhecido cujos objetos só se deixam ver parcialmente" ${ }^{2125}$. Ao voltar para contar os acontecimentos de suas viagens, o xamã adota "uma linguagem que expressa um ponto de vista parcial"126;

\footnotetext{
${ }^{124}$ KOPENAWA; ALBERT, 2015, p. 142.

125 CARNEIRO DA CUNHA, Manuela. Pontos de vista sobre a floresta amazônica: xamanismo e tradução. In.: Mana, v. 4, n. 1, 1998. p. 13.

126 Ibid.
} 
retorna com as palavras torcidas, fala numa linguagem que, em seu registro próprio, manifesta a incerteza da percepção alucinada"127.

Para esta pesquisa, é esse choque de perspectivas que atrai o xamã. Um conflito que parece carregar a força de uma quasidade fantasmal. Há uma incoerência viva nesse estado de véspera. Experiência "magnífica e apavorante" para Kopenawa, essa quasidade acontece no âmbito de um limiar da corporalidade que transita pelos modos de dizer e de viver do povo Yanomami. Há fantasmas no pensamento e na vida Yanomami como se pode sentir logo no início de A queda do céu. Quando Davi Kopenawa se dirige a Bruce Albert em "Palavras dadas" (capítulo em forma de carta no qual a escrita tem o tom de uma conversa presencial), o xamã se lembra do tempo em que o antropólogo foi viver com os Yanomami e "falava como um fantasma"128. Fica claro, conforme nota explicativa, que a "língua de fantasma" (aka porepë) é prerrogativa de falantes não Yanomami. Sendo assim, diz respeito a "expressar-se desajeitadamente, gaguejar, emitir sons inarticulados ou ser mudo" ${ }^{129}$. Isto é, um fantasma enquanto alguém que, vindo de mundos outros, chega ao mundo Yanomami para participar desta forma de vida.

Há algo de incômodo nas expressões "língua de fantasma" e "estado de fantasma": elas nos trazem exercícios perspectivistas que fazem estremecer nossa noção de corpo e os modos como se apresentam em nosso discurso as partes do corpo. Desse modo, podemos chegar à seguinte situação: se, por um lado, enquanto habitantes de um chão cultural plano que parece resumir a existência, organizamos nosso mundo recorrendo a diferenças estáveis e certezas racionais; por outro, algumas de nossas dobradiças conceituais podem ser sentidas, por exemplo, em nível do tratamento essencialista que dispensamos ao corpo. No sentido genérico de nossa cultura,

[...] o corpo tem uma existência própria [...], por isso, independente das relações que mantém com outros corpos; quem diz pessoa diz humanidade: só os humanos são pessoas; o corpo humano é tanto um princípio de individuação quanto um princípio de subjetivação ${ }^{130}$.

\footnotetext{
${ }^{127}$ CARNEIRO DA CUNHA, 1998. p. 13.

${ }^{128}$ KOPENAWA, ALBERT, 2015, p.63.

${ }^{129}$ Ibid., p. 610.

${ }^{130}$ LIMA, Tânia Stolze. O que é um corpo. In.: Religião \& Sociedade, v. 22, n. 1, 2002. p. 2-3.
} 
Quando digo que as expressões Yanomami são um incômodo é porque acredito que elas sejam capazes de abalar esses nossos modos mais arraigados de compreender um corpo e referenciar partes do corpo.

Para avançar na tentativa de exploração da quasidade fantasmal, voltemos ao choque de perspectivas. Para isso, gostaria de lembrar uma narrativa mítica, traduzida inicialmente por Koch-Grunberg:

Antigamente, os animais e as pessoas não tinham ânus para defecar. Acho que defecavam pela boca. Pu'iito, o ânus, andava por aí, devagar e cautelosamente, peidando no rosto dos animais e das pessoas, e depois fugia. Então os animais disseram: "Vamos agarrar Pu'iito, para dividi-lo entre nós!" Muitos se juntaram e disseram: "Vamos fingir que estamos dormindo! Quando ele vier, vamos pegá-lo!” Assim fizeram. Pu'iito veio e peidou na cara deles. Então correram atrás de Pu'iito, mas não conseguiram pegá-lo e ficaram para trás. Os papagaios Kuliwaí e Kaliká chegaram próximos de Pu'iito. Correram muito. Finalmente o pegaram e o amarraram. Então vieram os outros, que tinham ficado para trás: a anta, o veado, o mutum, o jacu, o cujubim, o pombo.... Começaram a reparti-lo. A anta pediu logo um pedaço para ela. Os papagaios cortaram um grande pedaço e o jogaram para os outros animais. A anta imediatamente o pegou. Por isso ela tem um ânus tão grande. O papagaio cortou para si um pedaço pequeno, como lhe era adequado. $\mathrm{O}$ veado recebeu um pedaço menor que o da anta. Os pombos tomaram um pedaço pequeno. Veio o sapo e pediu que lhe dessem também um pedaço. Os papagaios jogaram um pedaço na sua direção, o qual grudou nas suas costas: por isso o sapo ainda hoje tem o ânus nas costas. Foi assim que adquirimos nossos ânus. Se hoje não o tivéssemos, íamos ter que defecar pela boca, ou então arrebentar ${ }^{131}$.

Aos nossos olhos, para além da experiência com o cômico da narrativa e com a perplexidade que nos causa e que chega a ser constrangedora, será que o mundo mítico ameríndio pode nos ajudar a repensar algumas de nossas predileções culturais? Entre elas, a crença na natureza substancial das palavras e nos pensamentos autônomos que representam? Tudo isso segundo uma realidade indistinta e inexorável sob qualquer prisma? Ao escolher adentrar tal universo mítico, me pego tentando capturar as imagens verbais de $A$ queda do céu tanto quanto os animais tentam agarrar Pu'iito para compartilhá-lo. No mito, o ânus não é a parte anônima de um todo organizado. O ânus tem nome próprio e sua singularidade envolve inclusive o fato de que "andava por aí, devagar e cautelosamente". No entanto, em termos de esforço narrativo, observa-se que

131 MEDEIROS, Sérgio (Org.). Makunaíma e Jurupari: Cosmogonias Ameríndias. São Paulo: Perspectiva, 2002. p. 101-102. 
quase-nada acontece até que ocorre o encontro entre o ânus personificado e os corpos destotalizados de personagens em pedaços. A trama se interpela em torno desse encontro: da parte nomeada com a multiplicidade perspectiva dos corpos que vão se fabricando e por onde se movimentam os pontos de vista da narrativa. E a conclusão da história de Pu'iito se torna uma espécie de sentenciamento interrompido. Aquilo que poderia ter acontecido: o "arrebentar" que quase aconteceu.

Quando Tânia Stolze Lima, no texto "O que é um corpo", tenta apreender os laços mutuamente constitutivos entre a multiplicidade perspectiva do real e da linguagem para os Juruna, ela diz que, na língua e na vida daquele povo tupi, em vez de coisas isoladas as palavras são potenciais de intencionalidades.

Na língua juruna, muitas palavras jamais ocorrem dissociadas de um pronome possessivo. A palavra para peixe, ou para pedra, apresenta-se no discurso como nome de uma entidade dotada de existência própria, mas a palavra para pé só ocorre como uma entidade relativa: trata-se sempre do pé de alguém. É claro que peixe e pedra também podem ser referenciados a alguém, mas nesse caso adiciona-se uma marca gramatical específica para significar que a posse não é uma relação interna, intrínseca ou constitutiva do sujeito. Isso se dá com as partes do corpo, se dá também com os termos que designam relações de parentesco, com as palavras que designam pertences das pessoas, particularmente aqueles por elas mesmas produzidos, e, por fim, com as palavras para corpo e alma. (...) Corpo e alma não são substâncias, mas relações ou posições, ou ainda perspectivas ${ }^{132}$.

Nesse sentido, a similaridade entre os seres se manifesta para além dos aspectos que porventura os diferenciem. É possível dizer então que o ser se constitui por meio de uma língua-vida-mundo-corpo-pensamento-ação relacionáveis. Inspiro-me na análise de Stolze Lima, de uma forma de vida radicalmente outra, para dizer também que, embora as palavras e as frases que contam a história de Pu'iito se organizem num enredo simples - um enredo padrão dentro de um domínio semântico reconhecível por tribos ocidentais -, é evidente que nos mantemos diante de uma forma de vida estrangeira. Forma de vida incapturável. Como as imagens verbais de A queda do céu, disponíveis através da vitalidade imagética de que são indissociáveis.

Fantasmas vindos de longe, essas imagens se tornam capazes de nos devolver paradoxalmente uma imagem antagônica a nós mesmos. Como um repente que

${ }^{132}$ LIMA, 2002, p. 3. 
acontece, trazem consigo a experiência de imaginar com o corpo e o estado de quasidade desse imaginar. Experimentar a quasidade fantasmal nesse lugar de véspera, como condição próxima e a um passo da indistinção, é quase saber que uma coisa nunca se transforma em outra. Nunca se transforma, mas tem a possibilidade de seguir em outras direções. Assim, nós nunca nos transformamos "neles”, mas nossas identidades se dissipam interessando aqui ler as operações que possam atuar em função de novas possibilidades de pensar-viver-sentir: nós, os índios; nós, a floresta; nós, os animais... 


\section{4 \\ Ler com os índios: quatro exercícios}

\section{1. ...nós, os mortos: Amada, de Toni Morrison}

Sei o que é para mim ser cadáver ou sei para o cadáver o que é ser cadáver? A distinção me parece sem importância. $\mathrm{O}$ que eu sei é o que um cadáver não pode saber: que está extinto, que não sabe nada e que nunca mais saberá nada. Por um instante, antes de toda a minha estrutura de conhecimento entrar em colapso por pânico, estou viva dentro dessa contradição, morta e viva ao mesmo tempo.

Elizabeth Costello (John Coetzee, quase morto)

Nas formas de vida de grande parte da Amazônia indígena, a morte introduz uma operação perspectivista, experiência de alteridade radical: coloca imediatamente no horizonte dos índios o que poderíamos chamar de aspecto extra-humano do humano. Experimentar o contato com os mortos é um dos grandes problemas prático-metafísicos dos indígenas e a associação da morte ameríndia à alteridade radical é discutida, por exemplo, no ensaio "Perspectivismo e multinaturalismo na América indígena", de Viveiros de Castro. Para as cosmologias indígenas, "a distinção fundamental entre os vivos e os mortos passa pelo corpo, e não precisamente pelo espírito" (morrer é se transformar em animal ou em outras figuras da alteridade corporal); a morte é, portanto, “uma catástrofe corporal que prevalece como diferenciador sobre a comum 'animação' dos vivos e dos mortos"133. Não se trata de um desencarnar-se, de um tornar-se sem corpo; trata-se de antes perder um certo corpo, humano. $\mathrm{O}$ aspecto que aqui descrevemos do perspectivismo ameríndio pode ser compreendido à luz de Gabriel Tarde, segundo a noção de que corpo e alma, matéria e espírito, vida e morte não são oposições simples e estáticas, tampouco conceitos prontos ou lados que se excluem.

${ }^{133}$ VIVEIROS DE CASTRO, 2002a, p. 395. 
Mas estão conjugados em um mesmo campo ontológico guiado por propriedades transformadoras, não por essências:

Portanto, não digamos nem a outra vida nem o nada; digamos a não vida, sem nada prejulgar. A não vida, como o não eu, não é necessariamente o não ser; e os argumentos de alguns filósofos contra a possibilidade da existência depois da morte não pesam mais que os dos céticos idealistas contra a realidade do mundo exterior. ${ }^{134}$

É evidente que tal modo de compreender o jogo entre morte e vida desloca toda a ótica espiritual sob a qual se tende a observar a experiência da morte em formas de vida ocidentais. Em formas de vida indígenas, os vivos se produzem como iguais entre si e diferentes para os mortos. Nesse sentido, os mortos dos índios deixam de ser seus parentes. Com efeito, as histórias contadas pelos xamãs que viajam ao mundo dos mortos podem transformar o mais próximo parente de um índio em seu inimigo mais perigoso. Em outras sociedades humanas, não somente a ocidental, moderna e laicizada, mas aquelas baseadas em cultos ancestrais como, por exemplo, os povos antigos da China ou os da antiguidade grega, nessas sociedades, enfim, os mortos se tornam super-parentes, na medida em que manifestam o mesmo espírito. Os mortos estão ligados aos espíritos e, na configuração mítica de muitas sociedades ocidentais, a morte está ligada à ideia de alma como propriedade exclusiva da espécie humana.

\subsection{1.} Um modo xamânico de morrer

Se, para os indígenas, a morte expõe uma vida ao encontro com a alteridade radical, na beirada dessa outra dimensão, o xamã vê o que os mortos veem e passa a existir como intérprete e tradutor; como aquele que descreve e fabula; aquele que, ao se deixar expor à morte, torna sensível tal acontecimento, extraindo dali uma realidade passível de ser experimentada e transmitida. Naquele espaço discursivo, esse artista do corpo atua de modo a estabelecer um diálogo transespecífico. Como já vimos, a partir dessa atuação, é capaz de transitar entre diferentes estados de “ver como", sem perder

\footnotetext{
134 TARDE, Gabriel. Monadologia e sociologia. In: Monadologia e sociologia: e outros ensaios. Tradução de Paulo Neves. São Paulo: Editora Unesp, 2018. p.132.
} 
a própria condição de sujeito, e de voltar para contar a história. Ressalta-se, mais uma vez, que o xamanismo implica um certo ideal de conhecimento em que práticas e ideias andam juntas, sendo tal conhecimento radicalmente experimental e não totalizante e sendo a própria ideia de vida aquilo que se experimenta.

Esta é uma questão complexa, mas vejamos um de seus aspectos: especificamente, a morte como quase acontecimento. $\mathrm{O}$ quase acontecer é um modo de morrer que parece estar implicado na vida ameríndia no que diz respeito ao processo de iniciação xamânica. No caso de Kopenawa, em A queda do céu, já vimos, são narrados inúmeros episódios de confronto com o sobrenatural ao longo de sua vida. Tais episódios (para nós, alucinatórios?) constituem aspecto crucial para a apresentação da trajetória que lhe permitiu alcançar um grau de consistência na prática xamânica, cruzando barreiras corporais. Portanto, trata-se de acontecimentos de descoberta para Kopenawa em relação às suas possibilidades como xamã. Essas são experiências narradas em que ele invariavelmente quase morre.

Muitos estudos antropológicos se referem a esse tipo de experiência por que passam outros xamãs. Em boa parte dos estudos sobre o assunto, esse estado de risco pressupõe a exposição a um estado de nascimento e transformação. Gostaria de dar destaque aqui aos Ikpeng, povo que vive próximo ao Rio Xingu, sobre o qual pode-se dizer que a iniciação xamânica é de maneira geral uma ida ao mundo dos mortos.

A partir dos estudos de David Rodgers, o que se observa no âmbito da experiência de iniciação xamânica dos Ikpeng é a transformação do corpo do iniciado em um receptáculo para seres aquáticos entorpecidos. $\mathrm{O}$ penoso processo de iniciação envolve algumas etapas radicais. Entre elas, a condução do iniciado às profundezas da floresta. Ele é levado até lá para "inalar a fumaça de uma fogueira de cheiro doce proveniente da queima de seiva e de frutos de árvores, incluindo resinas de jatobá e copaíba, além de frutos da árvore de pequi e da palmeira tucumã’135. O iniciado, neste momento, permanece isolado: "[o] neófito é esvaziado [fazem-no vomitar], todos os contatos

\footnotetext{
135 No original: "to inhale the fumes from a sweet-smelling bonfire of tree saps and fruits, including jatobá and copaíba tree resins, plus the fruits of the pequi tree and tucumã palm” (RODGERS, 2013, p. 84).
} 
estranhos são reduzidos ao mínimo e seu corpo é coberto e preenchido apenas com fumaça aromática (...) [ele] é colocado em suspensão ontológica"136.

O processo culmina com a imersão do noviço em um "líquido de nascimento: mais precisamente, os pequenos riachos ou lagos nos quais os peixes são gerados"137. Submerso, deve olhar para a superfície da água, vendo gotejar, logo acima de seus olhos, a resina da casca de jatobá, queimada e derretida pelos xamãs já iniciados. A resina é descrita por Rodgers como um "fogo líquido"138 cujo aroma atrai seres aquáticos. Entre eles, o peixe-patrix (fonte espiritual de todos os peixes). O fogo líquido é um fluido parecido com mel que muitas vezes vem carregado de insetos aprisionados. Seu aroma e seu efeito efervescente na água atordoa os seres aquáticos. O mel, por sua vez, para os Ikpeng, é a única coisa que nunca perece. Em seu trabalho, David Rodgers afirma:

O emergir do iniciado da água é um nascimento após a morte (depois da vida): o iniciado quase morto - ou, mais exatamente, quase completamente imóvel [almost dead still], assim como um recém-nascido, sua pele pálida, selada por um filme membranoso com todos os estímulos sensoriais diminuídos e apenas o caos acústico em seus ouvidos ainda reverberando. ${ }^{139}$

Se é o nascimento de um quase morto, a que aponta a experiência do iniciado? Tal experiência se dirige primordialmente à dimensão paradoxal de uma morte nascente, já que a iniciação depende de um devir morto do xamã no processo de imersão em um pequeno riacho ou lago escuro onde são gerados os peixes. De acordo com o relato de Rodgers, o iniciado, ainda dentro d'água, está "aparentemente morto" e, sob esse ponto de vista ocidental, por um momento podemos pensar, de modo interessante, na oposição platônica entre verdade e ilusão. Contudo, importa destacar

\footnotetext{
${ }^{136}$ No original: "the neophyte is emptied, all extraneous contacts curtailed to a minimum, and his body covered and filled only with aromatic fumes. (...) is placed in ontological suspension" (RODGERS, 2013, p. 84-85).

${ }^{137}$ No original: "a birthing liquid: more precisely, the small streams or lakes in which fish are spawned" (Ibid.).

138. No original: "liquid fire" (Ibid.).

${ }^{139}$ No original: "The initiate's emergence from the water is a birth after death (after life), the initiate almost dead — or more exactly almost dead still, just like newborn infants, his skin pale-yellow, sealed by a membranous film with all sensory input diminished and only the acoustic chaos in his ears still reverberating" (Ibid., p. 86).
} 
que se trata ali de algo próximo a um estado "tongnore "bêbado/comatoso"140 — um estado de quasidade no qual os vários seres aquáticos preenchem o interior dos ouvidos do iniciado com o tumtankom deles ou "outro idioma"141. Este baixo som contínuo atrai Imere, deus Ikpeng da tempestade, também enfurecido pela morte, mesmo que temporária, da fauna aquática. Rodgers chama atenção para o fato de que, quando a tempestade passa e o iniciado revive, “as várias espécies na água também despertam e dispersam"142.

Essa experiência se repete em A queda do céu. A experiência de Kopenawa com o pó de yãnkoana (explorada no capítulo anterior) e a imagem deste apresentada na forma de um "sopro de vida" é um dos exemplos paradigmáticos desse modo de morrer que é um tornar-se vivo, junto com a verbalização desse tornar-se, como se as imagens verbais estivessem nascendo e as palavras com as quais se narra a experiência também, a partir do momento em que são pronunciadas. Nesse sentido, a partir do ato xamânico, produz-se a reciprocidade entre a viagem do corpo do xamã ao mundo dos mortos, isto é, seu trânsito ontológico, e o relato da morte propriamente dito: o quase morrer está nas palavras; e nas palavras está a vida nascente de uma forma de vida que quase morre. Não propriamente um quase subjetivo, mas um quase que liga os corpos a um movimento que ultrapassa a vivência pessoal. Instaura-se ali uma tensão, uma suspensão ontológica, que é esse viver entre corpos.

Por outro lado, nessa pesquisa de forças do quase, pode-se dizer que, na relação de um escritor com seus personagens, assim como no perspectivismo ameríndio, ele (o escritor) adota o maneirismo ${ }^{143}$ corporal de um personagem (passa a atuar na perspectiva de um corpo que se comporta de maneira diferente), sendo fundamental o fato de que a diferença dos corpos só é apreensível de um ponto de vista exterior, o que se estabelece com toda a intensidade de um encontro.

\footnotetext{
${ }^{140}$ No original: “(...) tongnore, “drunk/comatose” (RODGERS, 2013, p. 85).

141 No original: "the various aquatic beings fill the inner ears of the initiate with their tumtankom or "other-language" (Ibid.).

142 No original: “(...) the various species in the water also reawaken and disperse” (Ibid., p. 86)

143 "Longe do essencialismo espiritual do relativismo, o perspectivismo é um maneirismo corporal" (VIVEIROS DE CASTRO, 2002a, p. 380).
} 


\subsection{2.}

\section{Um morrer artístico-performativo}

Esses modos de pensar e de viver dos ameríndios, esses movimentos assombrosamente inventivos de encontro com a morte entre os Ikpeng e os Yanomami, lidos a partir de referências etnográficas amazônicas, trazem à luz, como vemos, um modo xamânico de morrer no qual alteridades intervêm para formar um espaço em que o quase demanda ser performado. Assim, pode ser um caminho fértil tomar a morte como quase acontecimento no universo ameríndio como intercessora para interrogar o que poderíamos chamar de um modo de morrer artístico-performativo em ficções articuladas em língua ocidental. Assumo aqui, vale lembrar, que linguagem é forma de vida, é sempre ação, performance - e que a arte é força de transformação de modos de agir inadvertidamente protocolares, é possibilidade de deslocamento de ações arraigadamente habituadas. Assim como os encontros com formas de vida radicalmente outras são um canal potente para se deixar atravessar por forças transformadoras.

Recorro nesse espírito às concepções indígenas de morte e ao modo xamânico de morrer para que, do encontro com esses mundos radicalmente diferentes, a força operatória do quase-acontecer possa aqui ser trazida para pensarmos a ficcionalidade da arte. Parto do pressuposto de que tal força advém da noção de um mundo em suspensão ontológica: mundo que está sendo reimaginado no entre corpos e dá corpo escritural a seres incorpóreos. Essa particular quasidade do morrer parece ter repercussões importantes tanto no mundo ameríndio quanto em experiências artísticas articuladas em língua ocidental. Entre outras coisas, não pode ser lida em registro homogêneo (ao contrário, dispara conecções inimagináveis) e se deixa compreender como uma imbricação entre vida e imaginação.

Buscarei apresentar aqui algumas dessas conexões inerentes, abordando o que reconheço como a imaginação de um quase-morrer no livro Amada, de Toni Morrison, na tradução de José Rubens Siqueira. A partir de um sem número de possibilidades de leitura, escolho começar considerando que a narrativa de Amada evoca e performa a quase morte, ao pautar-se em referências histórico-culturais da escravidão; a experiência dos negros na história dos Estados Unidos é, sabe-se, um problema típico 
do universo morrisoniano ${ }^{144}$. Entretanto, em Amada, não se trata da exposição ilustrativa e romanceada da escravidão ou de uma reflexão crítico-teórica sobre suas consequências nefastas. Enfim, em torno de uma obra vigorosa como Amada são inesgotáveis as possibilidades de leitura, como realmente tem ocorrido desde sua publicação. Por vezes, algumas até se confundem ao colocar em destaque a pertinência histórica do livro.

Em entrevista, ao refletir sobre a composição de Amada, Morrisson nos faz pensar que, diante da amplitude do sistema escravagista, nas narrativas que exploram tal veia temática, corre-se o risco de fazer desse sistema o centro do enredo de uma história. Portanto, para ela, interessava focar nas pessoas — na complexidade da vida dos personagens - e, desse modo, "pôr a autoridade de volta nas mãos dos escravos, em vez de colocá-la nas mãos dos senhores de escravos"145. Nesse sentido, Morrison escolheu abordar o tema da escravidão inspirada na história de uma personagem real: a escrava Margaret Garner que, juntamente com seus parentes, em 1856, fugiu de uma fazenda em Kentucky através do rio Ohio em direção à Cincinnati. Caçadores de escravos e xerifes encontraram Garner entrincheirada em um barracão. Grávida e acompanhada de seus quatro filhos, ela matou a filha de dois anos com um facão e feriu os outros três, tentando matá-los e a si mesma. Dessa performance macabra, é delicado distinguir a ação que provém do instinto materno de proteção daquela atribuída ao empenho em reivindicar um direito que Garner não tinha — o direito à propriedade: “e reivindicou tão definitivamente [a posse das crianças] que decidiu que, não só poderia ditar suas vidas, mas acabar com elas"146. Morrison acreditava que, a partir do momento em que se sabe qual seria o futuro dessas crianças, a decisão de Garner "não é tão difícil de entender" 147 .

\footnotetext{
${ }^{144}$ Uma das constantes do trabalho de Toni Morrison é contar e recontar histórias que apontam para o preconceito racial. Nesta entrevista, ela se refere ao racismo dentro do meio literário: "I'm writing for black people," she says, "in the same way that Tolstoy was not writing for me, a 14-year-old coloured girl from Lorain, Ohio. I don't have to apologize or consider myself limited because I don't [write about white people] - which is not absolutely true, there are lots of white people in my books. The point is not having the white critic sit on your shoulder and approve it" - she refers to the writer James Baldwin talking about "a little white man deep inside of all of us". Did she exorcise hers? "Well I never really had it. I just never did." (HOBY, 2015).

${ }^{145}$ Disponível em: <https://www.youtube.com/watch?v=2jxN3oTSD34>. Acesso em 16 mar. 2020.

${ }^{146}$ Disponível em: <https://www.youtube.com/watch?v=2jxN3oTSD34>. Acesso em 16 mar. 2020.

${ }^{147}$ Disponível em: <https://www.youtube.com/watch?v=2jxN3oTSD34>. Acesso em 16 mar. 2020.
} 
Como tentarei demonstrar a seguir, a leitura dos sentidos de um morrer em Amada, a partir do qual Morrison faz ecoar o registro da violência contra a vida de multidões, pode ser formulada exatamente pela imbricação entre vida e imaginação que é objeto desta tese. Penso que a experiência de contato com a morte em Amada não adquire sua maior força na lembrança de fatos históricos cruciais articulados pela narrativa; esta que, vale ressaltar, tampouco obedece ordem factual e cronológica. Eu acrescentaria mais: não consigo pensar que um dos declarados objetivos de Morrison como artista - o não apagamento do passado - passe por um mero apego aos fatos históricos. O que quero dizer com isso tudo é que vejo no livro a potência inventiva de um quase ser. Um tipo de ser incorpóreo construído a partir de uma experiência de quase morte - essa experiência que a arte mobiliza de modos distintos e que, em Amada, acontece no corpo.

Como tentarei mostrar adiante, o quase ser que se constitui no tratamento dado à narrativa por Morrison (tratamento específico, nos termos de Saer ${ }^{148}$ ) pode ser lido na geografia de uma árvore traçada por uma cicatriz que marca as costas de Sethe: mulher, negra, vítima de açoites, abuso moral e violência sexual. Na vizinhança cósmica da protagonista - nesse espaço de experiência que é uma ficção — , gravitam, entre outros, os seguintes personagens: Paul D, um velho amigo dos tempos de escravidão; Denver, a filha que mora com Sethe na casa conhecida por todos pelo seu número, 124; Buglar e Howard, os filhos que fugiram de casa; Amy, a "moçabranca" que irá ajudála na travessia do rio e cuidará de seus ferimentos; e a jovem que diz se chamar Amada e que Sethe passa a acreditar ser a filha morta reencarnada. Esta foi a filha assassinada pela mãe aos dois anos de idade durante um episódio de fuga, depois de a protagonista cruzar o rio e se esconder em Cincinnati, no estado livre de Ohio. À época, quase uma menina, frágil diante da iminente captura por conta da aproximação dos caçadores de escravos, Sethe avança contra os filhos empunhando um serrote. A filha que se chama Amada é a única que não sobrevive à investida da mãe.

\footnotetext{
148 “Esse desejo não é um capricho de artista, mas a condição primeira de sua existência, porque somente sendo aceita como tal é que se compreenderá que a ficção não é a exposição romanceada de tal ou qual ideologia, e sim um tratamento específico do mundo, inseparável da matéria de que trata" (SAER, 2009, p. 322).
} 
Na trama, a conexão com o mundo dos mortos começa a se estabelecer a partir da movimentação de um fantasma bebê. Este ainda é parente, é filha. Ainda assim, traz com esse parentesco, o aspecto extra-humano do humano. $\mathrm{O}$ fantasma bebê cria o terror entre os personagens ao perambular pela casa de número 124 da Bluestone Road, em Cincinnati, onde a protagonista está morando. Da ação sobrenatural, revelada pela narrativa, destacam-se o momento em que um dos filhos de Sethe olha para um espelho (aterrorizado, Buglar vê o espelho se estilhaçar) e a passagem da aparição, para outro filho, de duas mãozinhas impressas na massa de um bolo. Os garotos interpretam esses detalhes como um sinal e resolvem fugir de casa. Dezoito anos mais tarde, com a chegada do personagem Paul D na trama, o fantasma bebê é expulso de casa por ele. Logo uma estranha jovem aparece: ela surge de dentro do riacho (sem que ninguém a visse surgir) e permanece sentada à margem (sem que ninguém a notasse ali) encostada no tronco de uma amoreira por cerca de um dia e uma noite até caminhar rumo ao número 124 onde é finalmente vista por Sethe, pela filha Denver e pelo companheiro Paul D, no momento em que dobravam a curva da estrada voltando para casa vindo de uma festa. A jovem Amada passa a conviver com eles.

Não se pode, contudo, deixar de observar que, por toda a narrativa, circulam árvores. Morrison as dispõe na fileira de pinheiros perto do rio, no bosque dos fundos e ao redor da fazenda onde Sethe viveu. Uma fazenda, no estado de Kentucky, ligada a uma vida escravizada cujo passado não está morto. Se grande parte das árvores dispostas no livro apenas compõem o cenário onde se desenrola o que acontece ali, como a estratégia narrativa de Morrison nos permite investigar a experiência de contato com a morte tomando-se, assim como aqui proponho, o mundo vegetal como ponto de partida? Vejamos o uso que Morrison faz desse mundo: em Amada, há uma operação do quase inscrita entre o enfrentamento da morte e o acontecimento da escravidão quando a escritora usa as costas da protagonista Sethe, laceradas pela tortura, marcadas

por uma espécie de árvore, para performar-transmitir uma experiência. É possível que Morrison tenha tirado a ideia da cicatriz de uma imagem que circulou amplamente no norte dos Estados Unidos, durante a guerra civil e que mostra as marcas nas costas de um escravo chamado Peter de Baton Rouge (Louisiana). 


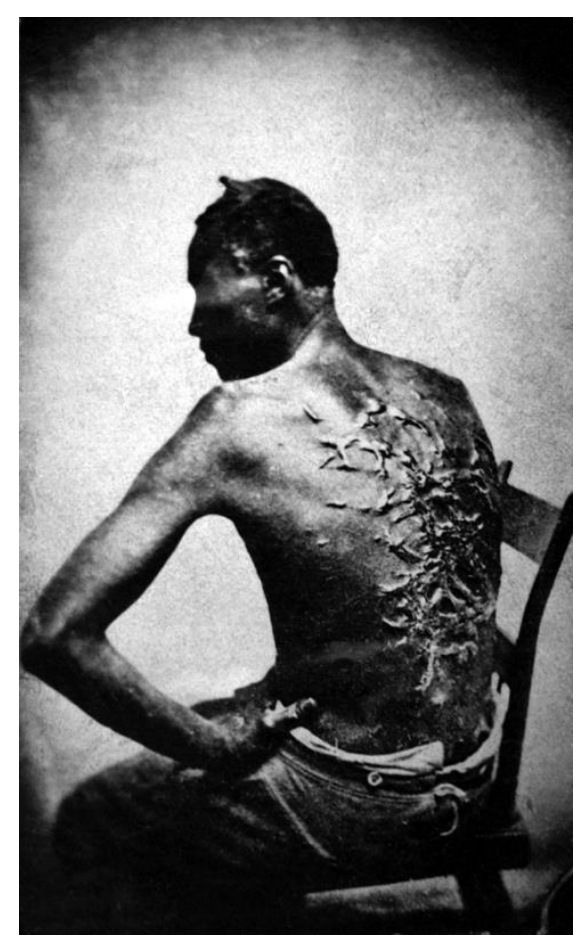

Figura 1- Scars of a whipped Mississippi slave, autor desconhecido. 1863.

As escaras são provenientes de chicoteamento aplicado por um capitão do mato. Pensar sobre isso faz com que me sinta ainda mais inclinada a sugerir que a leitura da cicatriz nas costas de Sethe em Amada pode dialogar frutiferamente com a experiência de quasidade. A maneira como Morrison se inspira nesse episódio para fazer arte extingue a nossa necessidade de informação sobre esse fato específico na circunstância real de composição do livro. Prefiro imaginar que, como um xamã, a escritora se deixa levar por tal fato até a borda de um morrer artístico-performativo que faz o episódio mudar de natureza. A cicatriz em Amada é como um fóssil vivo: é quase uma árvore viva a convocar a febre, a convulsão, o inchaço, as secreções e a dor latejante das feridas que estavam ali, no emprego mortífero da escravidão. Tais feridas não são imaginárias, num sentido desencarnado de imaginação. Tampouco se dissociam de um mundo ao redor ou do que se pode observar desse mundo: estão inscritas na superfície porosa de um corpo e, portanto, desenham uma árvore em conflito e contágio com as outras do cenário, que contam em silêncio possibilidades não humanas de vida. 
Em Amada, a primeira menção às marcas físicas nas costas de Sethe é feita no seguinte diálogo entre a protagonista e Paul D, de quem é amiga desde o período em que ambos viveram como escravos na fazenda em Kentucky:

"Tem uma árvore nas minhas costas e um fantasma na minha casa, e nada entre uma coisa e outra além da filha que está aqui nos meus braços."

(...)

"Que árvore você tem nas costas?"

"Hã?” Sethe pôs a tigela na mesa e procurou a farinha, embaixo.

"Que árvore nas costas? Tem alguma coisa crescendo nas suas costas? Não vejo nada crescendo nas suas costas."

"Está aí, mesmo assim."

"Quem te disse isso?"

"A moçabranca. Era assim que ela falava. Eu nunca vi, nem nunca vou ver. Mas era isso que ela disse que parecia. Uma árvore de arônia. Tronco, galhos e até folhas. Folhinhas pequenas de arônia. Mas isso foi dezoito anos atrás. Agora, já podia até ter dado fruta." 149

O surgimento da árvore na narrativa acontece sob a sombra do fantasma bebê ("'da filha que está aqui nos meus braços”). Se, neste momento, é uma cicatriz, dezoito anos atrás foi uma árvore florida de pus. Logo adiante, quando Paul D vê as costas de Sethe, confere-lhe mais uma topografia que nos faz experimentar uma radical mobilidade de perspectivas:

Não uma árvore, como ela disse. Talvez com a forma de uma, mas nada a ver com nenhuma árvore que ele conhecesse porque árvores são atraentes; coisas em que se pode confiar e estar perto; com que se pode conversar se quiser, como ele fez tantas vezes desde quando tomava a refeição do meio-dia nos campos da Doce-Lar. ${ }^{150}$

A árvore já havia se tornado uma cicatriz contra a qual Paul D evoca toda a sua experiência anterior com o mundo vegetal. Nessa passagem, surge já algo diferente do modo ocidental de imaginar: a princípio, esse "nada a ver com nenhuma árvore que ele conhecesse" — além da "forma de uma" — indicaria, para nós, a prevalência de características de uma criatura pertencente a um mundo separado do humano. Porém, surge algo diferente porque, na sequência, temos árvores com as quais se pode

\footnotetext{
${ }^{149}$ MORRISON, Toni. Amada. Tradução de José Rubens Siqueira. São Paulo: Companhia das Letras, 2007. p.33-34. ${ }^{150}$ Ibid., p. 40.
} 
conversar. Entre os africanos escravizados, as relações mortos-vivos e humano-não humano eram compreendidas de modo diferente daquele dos escravizadores brancos. Aqui vale mencionar mais uma vez a entrevista de Morrison, citada anteriormente: nessa entrevista aprendemos com a escritora que fazia parte do modo de vida do povo negro pensar em termos de uma relação íntima entre vivos e mortos, e humanos e não humanos ${ }^{151}$. Esta importante relação de continuidade entre os mundos vegetal e humano - entre Paul D, os acontecimentos vividos por ele em torno das árvores que conhecera (uma dessas, ele a chamava de "Irmão") e a cicatriz de Sethe — conduz o personagem a um processo de saída de si. Vida escravizada, a de Paul D vai se alterando infinitamente a cada ferida exposta pela narrativa. $\mathrm{O}$ modo pelo qual sua memória resgata um episódio de tortura, quando ficou preso com um instrumento de ferro em seu rosto, é um exemplo. A passagem é significativa: à margem da lembrança, oferecese a visão de um pinheiro, ali onde comparece em primeiro plano o encontro de Paul D com um galo, o galo Mister:

\begin{abstract}
"Os galos", disse ele. "Passar na frente dos galos vendo eles me verem." (...) "Mister também?" Sethe sorriu. "Naquele pinheiro?" "É." Paul D sorriu para ela. "Devia ter uns cinco empoleirados lá e pelo menos cinquenta galinhas. (...) Mister, ele parecia tão... livre. Melhor do que eu. Mais forte, mais valente. (...) Mister podia ser e continuar sendo o que era. Mas eu não podia ser nem continuar a ser o que eu era. Mesmo que cozinhassem ele, iam cozinhar um galo chamado Mister. Mas eu de jeito nenhum ia ser Paul D outra vez, vivo ou morto. (...) Eu era outra coisa e essa outra coisa era menos que um galo pousado numa banheira debaixo do sol.",152
\end{abstract}

Essa passagem traz à luz uma marca de vida que pode ser relacionada ao modo de pensar e de viver indígena: este modo atravessado pela alteridade radical em que o "eu" não é a sede monárquica da operação visiva; ou seja, vejo e o tempo todo sou visto. Nessa condição, para Paul D, era inviável morrer de todo. Era possível apenas se sentir menos que um galo pousado numa banheira debaixo do sol. E nessa desolação havia até mesmo uma certa curiosidade por parte do personagem: afinal, qual devia ser a sensação de se empoleirar em um pinheiro e de bater as asas de lá quando quisesse, um pinheiro que, na passagem, desempenha a função de dizer para Paul D que ele não era

\footnotetext{
${ }^{151}$ Disponível em: <https://www.youtube.com/watch?v=2jxN3oTSD34>. Acesso em: 16 mar. 2020.

152 MORRISON, 2007, p.106-107.
} 
livre. Não sendo livre, estava também excluído de sua própria humanidade. E depois de ser torturado, Paul D era ainda uma outra coisa. E, por outro lado, essa outra coisa fazia com que ele quisesse seguir adiante.

Morrison convida o leitor a entrecruzar essas sensibilidades para produzir a leitura dos sentidos de um morrer artístico-performativo. E muitas vezes explora feridas e cicatrizes que resistem à decomposição. Desse modo, desconvida-se a tentativa de nos relacionarmos com tal viscosidade e tal solidez de maneira hermenêutica, impede-se sobretudo que caminhemos pelas trilhas que compõem a narrativa da saga de um povo para tentar entendê-la de modo individualizado e homogêneo. Penso que, mesmo imersos nesses inúmeros automatismos hermenêuticos que nos guiam, há em Amada uma convocação importante para uma experiência.

O contato com esse mundo majoritariamente escravocrata se dá mantendo-se o mundo vegetal sempre à vista, radicalizando-o, a partir de um bloco de tremor que mobiliza forças vivas e obscuras. Como será indicado posteriormente, é importante o abalo da enunciação tornando permeáveis vida e morte. Um abalo que faz ranger o pensamento e nos arrasta para uma aridez purulenta diante da visão de uma árvore cravada no corpo da mulher negra. É uma cicatriz que fala, “[c]oisa que Sethe não podia sentir porque a pele de suas costas estava morta havia anos"153. A perda da sensibilidade na superfície das costas não tem um sentido figurado, mas é oriunda da energia mortal da escravidão. E o fato fundamental ali é o de que a pele deformada pelo açoite se metamorfoseia em formas de vida (humanas ou não) que (como a própria pele negra) lutaram séculos contra energias mortais e continuam lutando contra a exploração determinante de uma marginalidade ainda presente. Olhar para essa pele é sentir que um quase-morrer insiste no organismo vivo de multidões, em Amada, e é aí que está a sua riqueza, nesse modo de subsistência da morte.

Essa é uma hipótese importante para “A morte como quase acontecimento", de Eduardo Viveiros de Castro: “[t] odos sabem que a morte só acontece aos outros, temos a este respeito um saber puramente teórico"154. Impossibilitados que estamos de morrer e voltar para contar, a abertura para a experiência da morte em primeira pessoa só nos

\footnotetext{
${ }^{153}$ MORRISON, 2007, p.36.

${ }^{154}$ Referência bibliográfica central para este capítulo (VIVEIROS DE CASTRO, 2009).
} 
acomete em sua quasidade, quando acontece outra coisa que não aquele algo. $\mathrm{O}$ acontecimento da morte que me interessa em Amada é feito desse quase acontecer. Alexandre Nodari se inspira no neologismo da quasidade forjado por Eduardo Viveiros de Castro para cunhar o termo encenunciação, tal como escreve em "Quase-evento: sobre a estoricidade da experiência literária":

Brás Cubas nunca enunciou suas Memórias Póstumas: estas constituem uma enunciação fictícia que precisa ser, a cada vez, encenada pelos leitores (e antes deles, pelo seu "autor", Machado de Assis), que demanda o que sugiro chamar, para marcar uma indiscernibilidade entre enunciação e encenação, uma encenunciaçãoo ${ }^{155}$

Em torno da pergunta "o que acontece quando o não acontecido acontece?", Nodari problematiza composição e leitura do texto ficcional afirmando seu caráter performativo. A partir da tentativa de esboçar uma ontologia não do objeto, mas antes da experiência literária, o pesquisador busca elementos constantes da ficção. Nesse texto, Nodari toma como ponto de partida a definição de Barbara Smith, de poesia como enunciação fictícia ${ }^{156}$, para afirmar que "é por jamais ter ocorrido de uma vez por todas que uma enunciação fictícia não cessa de recorrer, de ocorrer a cada vez que é performada (pela sua composição, pela sua leitura, mesmo que silenciosa, pelas suas traduções e adaptações)" ${ }^{\prime 157}$.

\subsection{3.}

\section{Modos de narrar o indescritível}

A encenunciação de Morrison, em Amada, abre para a experiência típica no mundo ameríndio do "quase encontrar" no contexto do sobrenatural. Vejamos especialmente um dos aspectos que podem conectar tal experiência à experiência do quase acontecimento: segundo David Rodgers, a fórmula "quase encontrar" (iwompin) contém o sufixo pin que tipicamente implica em um evento que "quase aconteceu",

\footnotetext{
${ }^{155}$ NODARI, A. Quase-evento: sobre a estoricidade da experiência literária. In.: eLyra: Revista da Rede Internacional Lyracompoetics, n. 10, 2018. p.57.

${ }^{156}$ Essa investigação faz parte do texto SMITH, 1968, importante para Alexandre Nodari para a discussão sobre os aspectos da enunciação fictícia e sua performance.

${ }^{157}$ NODARI, 2018, p.57.
} 
conforme tradução do Ikpeng para o português. Para o pesquisador, o sufixo pin, como um marcador de tempo e de modo, traduz-se como estado passado e futuro, sugerindo que tais modalidades podem ser atribuídas com mais precisão ao virtual ou quase: “quasi-event-taken"158 — algo ainda não desenvolvido, mas atualizável. Diante da imagem da árvore cravada nas costas da personagem Sethe e narrada pela personagem da "moçabranca" que irá ajudá-la na travessia do rio (cena que será lida no decorrer deste capítulo), impossível não pensar na seguinte narrativa:

Como inúmeros mitos Ikpeng ilustram, seres perdidos agem como um atrativo para estranhos. O isolamento implica exposição ao risco de ser abduzido e absorvido por outros de qualquer tipo (como Taylor, 1993, escreve sobre os Jivaro). Esta exposição através do isolamento coexiste com o desejo de autonomia, exemplificado pelo caçador solitário - mas é precisamente essa redução a uma singularidade pura sozinha na floresta que parece maximizar o perigo de uma perda catastrófica de volição. Embora este perigo seja difuso em alguns sentidos, os caçadores frequentemente mencionam encontros com uma sirene da floresta chamada Enoy. Vivendo no tronco de uma árvore, ela atrai caçadores isolados com seu canto estranho e compulsivo. No entanto, esses incidentes não são exatamente acidentes: sua aproximação é induzida pelos devaneios do caçador em torno de uma amante enquanto ele caminha pela floresta em busca de trilhas de animais. Mais frequentemente, ele ouve apenas a voz alarmante dela e retorna para o assentamento ou acampamento imediatamente contando este quase evento a outros com um tipo de apreensão irônica: iwompin enoy, "Eu quase encontrei Enoy." Mas se ele realmente responde ao seu magnetismo selvagem e se aproxima, ele a encontra deitada debaixo de uma árvore com as pernas abertas, exibindo sua grande vulva e abundantes pelos pubianos. Se tentar ter relações sexuais, o caçador descobre tarde demais que seu corpo está em desordem: ela não tem uma vagina e, no lugar de um umbigo, tem outra boca que devora o caçador, transformando-o em um ser "exatamente como ela", passando ele a viver em seu mundo-árvore. Um nascimento reverso ou Implosão. A absorção mortal do caçador não é em si uma singularidade, mas uma pluralidade que se manifesta como singular. Consequentemente, embora Enoy se apresente como uma fêmea individual — petkom arak, "parecida com uma mulher" ela na verdade se configura como uma espécie fenômeno, uma latência na floresta. ${ }^{159}$

${ }^{158}$ RODGERS, David, The filter trap: Swarms, anomalies, and the quasi-topology of Ikpeng shamanism. In.: HAU: Journal of Ethnographic Theory. v. 3, n. 3, 2013. p. 95.

${ }^{159}$ No original: As numerous Ikpeng myths illustrate, lost beings act as strange attractors. Isolation entails exposure to the risk of being abducted and absorbed by others of any kind (as Taylor 1993 writes on the Jivaro). This exposure through isolation coexists with the desire for autonomy, exemplified by the solitary hunter-but it is precisely this reduction to a pure singularity alone in the forest that appears to maximize the danger of a catastrophic loss of volition. Although this danger is in some senses diffuse, hunters often mention their close encounters with a forest siren called Enoy. Living in the bole of a tree, she lures isolated hunters toward her with her weird, compulsive singing. Yet these incidents are not exactly accidents: her arrival in the vicinity of the hunter is induced by his daydreaming about a lover as he treks through the forest in pursuit of animal tracks. More often he hears just her haunting voice and returns to the settlement or camp site immediately, recounting this near event to others with a kind of 
É a partir dessas leituras atravessadas pelo quase, com Nodari, com Viveiros de Castro e com Rodgers, que respondo às estratégias performativas do modo de narrar em Amada. Frente a esse caráter singularmente performático da narrativa, pela estreita ligação com um fazer e pela implicação de corpo envolvida, o registro de um mundo vegetal cravado nas costas de Sethe em Amada se insere na noção de morte como quase acontecimento e de uma pluralidade que se manifesta como singular. Opõe-se a tal pluralidade qualquer possibilidade de unir dimensões separadas, abrindo espaço para um canal potente, por onde circula uma respiração e ecoam gemidos de dor. Uma dor histórica? Uma dor cultural? Uma dor que insiste em ser a dor da personagem Sethe, uma dor de um corpo que não é mais só dela.

Assim, de cipó em cipó, faz-se aqui um convite para pularmos no meio da cena escritural em que se narra o que acontece quando as forças de morte penetram o corpo de Sethe. Nesse ponto, o embate com a morte começa a acontecer, em retrospectiva, pela personagem Denver, de quem parte o foco narrativo. As imagens que serão apresentadas ao leitor mostram o que aconteceu no dia do nascimento de Denver. Esta filha sobrevivente conduz o olhar de Amada. Eis então que, nesse momento da narrativa, a filha morta que emergiu do rio se torna a interface que intermedia a ligação do leitor com a história a ser contada. Leitor e narrativa se conectam por meio da filha morta, é um fantasma quem agora escuta uma história. Tais fronteiras entre morte e vida, fronteiras estas não necessariamente delimitadas, introduzem aqui uma convergência e uma divergência para se pensar a iniciação xamânica dos Ikpeng em relação à experiência artística de Morrison.

No livro, aquela que começa a ver aquilo que está narrando (como um xamã), ou seja, aquela que viaja ao mundo dos mortos, é então a filha sobrevivente. Embora não seja aquela que emergiu do rio (como entre os Ikpeng), pesa sobre a personagem

wry trepidation: iwompin enoy, "I almost encountered Enoy." But if he actually responds to her allure and approaches, he finds her lying beneath a tree with her legs apart, displaying her large vulva and abundant pubic hair. If he attempts to have sex, the hunter discovers too late that her body is in disarray: she lacks a vagina, and in place of a navel, she has another mouth that consumes the hunter, turning him into a being "just like her," living in her tree-world. A reverse birth or implosion. The hunter's deathly absorption is thus not into a singularity, but into a plurality which manifests as singular. Consequently, although Enoy appears as a single female - petkom arak, "woman-like"-she actually conforms to a species phenomenon, a latency in the forest" (RODGERS, 2013, p. 95) 
Denver a situação de "dead still”, como se estivesse narrando de dentro de um lago escuro - o útero da mãe:

Denver parou e suspirou. Era essa a parte da história de que ela gostava. Estava chegando nela agora e adorava aquilo porque era toda sobre si mesma (...). Agora, vendo o rosto alerta e faminto de Amada, como ela absorvia cada palavra, fazia perguntas sobre a cor e o tamanho das coisas, sua ânsia aberta de saber, Denver começou a ver o que estava dizendo e não só a escutar: lá estava aquela escrava de dezenove anos - um ano mais velha que ela -, andando pelo bosque escuro para chegar a seus filhos que estão longe. Ela está cansada, com medo talvez, e talvez até mesmo perdida. Quase todo o tempo está sozinha e dentro dela há um outro bebê em quem tem de pensar também. (...) Denver agora via e sentia - por meio de Amada. Sentia qual devia ter sido a sensação de sua mãe. Via como devia ter sido. E quanto mais esclarecia os pontos, quanto mais detalhes fornecia, mais Amada gostava. Então ela se adiantava às perguntas injetando sangue aos retalhos que sua mãe e avó tinham lhe contado - e uma pulsação. O monólogo se transformou, na verdade, em um dueto com as duas deitadas juntas, Denver alimentando o interesse de Amada. ${ }^{160}$

Aqui, a quasidade insinua-se desde o começo, no rosto faminto de Amada. Como já foi dito, Alexandre Nodari se vale da quasidade para aproximar-se da palavra "como" que designa também:

[o] ato de comer na primeira pessoa do singular do presente do indicativo. Se isto é apenas uma coincidência linguística, a relação entre comer e metaforizar não é casual, como demonstra a filosofia de Nietzsche, pensador da metáfora e da devoração, da metáfora da devoração. $\mathrm{O}$ ato de comer é sempre um ato de transformação, ambivalente e indecidível: por um lado, incorporação do outro no mesmo; por outro, metamorfose do próprio no outro: "você é o que você come". Por isso, dizer "eu como" é também afirmar que o eu que come é um como-Eu (nos dois sentidos), um ser liminar (e irreal) que está na situação da "quasidade" (Viveiros de Castro), que está na iminência da transformação. ${ }^{161}$

Amada era a que absorvia cada palavra. Na sequência, Denver se aproxima mais e mais da irmã morta. Sua voz vai se tornando baixa e misteriosa ao modo de um contador de histórias experiente. Há ainda um silêncio nos intervalos dessa aproximação que é próprio de um pulsar. O pulsar de uma solidão povoada por aqueles que, paradoxalmente, estão proibidos de contar a história. O silêncio povoado de

\footnotetext{
${ }^{160}$ MORRISON, Toni, 2007, p.112-113.

${ }^{161}$ NODARI, Alexandre. Como (verbete). In: Sopro. n. 78, 2012.
} 
solidão persegue a voz de Denver até lançar luz às imagens que passarão a ser apresentadas pela personagem Sethe. Nesse ponto, gostaria de assinalar que tal desvio de foco narrativo produz o efeito de alcançar o emaranhado de sensações do corpo da mãe no momento da fuga (o cansaço, o medo, a desorientação). Assim, Denver passa a palavra a Sethe e, a partir de então, a protagonista introduz a personagem Amy como um bafo fumacento soprando em sua direção. Um bafo que faz ondular as águas do rio onde flutuará uma promessa de liberdade:

Denver falava, Amada ouvia, e as duas fizeram o melhor que podiam para criar o que realmente acontecera, como realmente tinha sido, uma coisa que só Sethe sabia porque só ela tivera cabeça para aquilo e o tempo, depois, para moldá-la: a qualidade da voz de Amy, seu hálito como madeira queimando (...). Como tinha sido descuidada com essa moçabranca - um descuido nascido do desespero e encorajado pelos olhos fugidios de Amy e sua boca enternecedora (...). ${ }^{162}$

Só Sethe sabia, mas não podia ver a dor que sentia com clareza em suas costas. A partir daí, Amy, a "moçabranca" que cuidará de seus ferimentos, irá ajudá-la no parto de Denver e na travessia do rio, com voz de sonâmbula, torna visíveis as feridas como uma forma de vida sensível ao que acontece de mais pujante. Acontecimento irredutível ao feixe de sensibilidades que constitui o corpo de Sethe morrendo isoladamente.

"Minhas costas estão doendo", disse.

"As costas? Menina, você está um bagaço. Vire aí e deixe eu ver."

Num esforço tão grande que a deixou enjoada do estômago, Sethe virou sobre o lado direito. Amy desamarrou as costas do vestido e disse "Vem cá, meu Deus!" quando viu. Sethe concluiu que devia estar feio porque depois daquele apelo a Deus Amy ficou sem falar durante algum tempo. No silêncio de uma Amy calada de surpresa só para variar, Sethe sentiu os dedos daquelas mãos boas tocarem de leve suas costas. Conseguia sentir a respiração da moçabranca, mas ela não disse nada. Sethe continuou imóvel. Não conseguia deitar de barriga para baixo nem de costas, e manter-se deitada de lado significava pressão nos pés, que gritavam. Amy enfim falou com sua voz de sonâmbula. "É uma árvore, Lu. Uma árvore de arônia. Está vendo, aqui o tronco - é vermelho e bem aberto, cheio de seiva, e aqui bem a separação dos galhos. Tem uma porção de galhos. Folhas também, parece, e quero me danar se isto aqui não são botões. Uns botõezinhos de cerejeira. Tem uma árvore inteira nas suas costas. Florindo. O que Deus tinha em mente, eu me pergunto. Eu levei umas boas chicotadas, mas não me lembro de nada assim. E olhe que mr. Buddy tinha uma mão bem ruim. ${ }^{163}$

\footnotetext{
${ }^{162}$ MORRISON, 2007, p.113.

${ }^{163}$ Ibid., p.114-115.
} 
Quanto às feridas de Sethe, convém reafirmar: elas se metamorfoseiam na cicatriz, inscrita na própria pele da protagonista e na pele de outros (humanos ou não), a partir de uma dinâmica que cria um espaço de coabitação do $e u$ e do outro. Ocorre o seguinte: por um lado, o fato de a carne de uma pessoa ter sido cortada se relaciona aos corpos das palavras que acabaram de compor tal declaração, havendo aí uma efetuação espaçotemporal que gera a sucessão de dois estados de coisas indicados pelo enunciado. Assim, uma cicatriz encontra-se presente nos corpos de multidões (humanas ou não) antes de a escrava Sethe ter sido ferida, porque sabemos que ela será ferida e que milhões de vidas sangrarão no tempo da narrativa e nos séculos seguintes. Do mesmo modo, a cicatriz funciona como resultado de uma interação de corpos (por exemplo, carne e punhal, carne e chicote), em que o ferimento produz a regeneração biológica daquele que foi ferido: um acontecimento com causa e consequência plenamente explicáveis. Isto é, existe ali uma ferida cicatrizada perfeitamente cognoscível do ponto de vista científico. Mas há algo que insiste para além dessa forma de vida existente: impassível, inabalável, enigmático, incorporal.

Como tomar essa dimensão incorporal? Aqui vale recorrer aos estoicos, que instauram pela primeira vez uma lógica do acontecimento na dobradiça do mundo clássico para o helenístico. Uma lógica baseada em tipos de entidades que estão além dos corpos; não um além espiritual (religioso ou metafísico), mas um além que diz respeito justamente ao que chamaram de incorporais. Ou seja, uma lógica que, a partir dos incorporais, propõe uma concretude. No prefácio da edição brasileira do livro de François Zourabichvili, Deleuze: uma filosofia do acontecimento, existe uma distinção clara daquilo que os incorporais fazem: "É próprio do acontecimento ser um efeito virtual incorpóreo irredutível ao estado de coisas nos quais se efetua."164. Em pelo menos dois outros momentos do livro, Zourabichvili aciona os incorporais na tarefa de pensar a noção deleuziana de acontecimento, de um modo relevante para o que nos interessa aqui:

164 ZOURABICHVILI, François. Deleuze: uma filosofia do acontecimento. Tradução de Luiz B.L.Orlandi. São Paulo: Editora 34, 2016. p. 14. 
O espírito é realmente distinto do corpo, mas não constitui uma ordem de existência originariamente separada e independente: ele é a própria sensibilidade (ou o afeto), ou antes sua parte inefetuável e incorpórea, a coexistência virtual, pelo menos momentânea, que ela implica. O espírito emerge na superfície do corpo, o espírito é o acontecimento naquilo que ocorre. (...) Sem dúvida, uma proposição designa e significa um estado de coisas, mas ela não poderia fazê-lo sem envolver o acontecimento incorpóreo que ele encarna. ${ }^{165}$

A passagem revela que, mesmo resistindo em um espaço demarcado, uma cicatriz é o índice de alguém ter sido ferido e se impõe tanto como o atributo de um corpo quanto como o manifesto neste texto/proposição (ter sido cortado). Pois uma maneira possível de compreender o acontecimento incorporal é remetê-lo ao sentido das frases, tomando-o como sendo inseparável ao de um devir mundo; e expô-lo ao pensamento, tomando-o como sendo inseparável da experiência. Assim, na dimensão concreta da realidade, quem traz consigo uma cicatriz carrega também um acontecimento incorporal. Em Lógica do sentido, aprendemos com Deleuze que esses efeitos incorporais seriam como o verdejar de uma árvore, ocorrem "na superfície, neste tênue vapor incorporal que se desprende dos corpos, película sem volume que os envolve, espelho que os reflete, tabuleiro que os torna planos" ${ }^{" 166} \mathrm{E}$, nesse mesmo livro, estabelece sua concepção de acontecimento próxima ao que diz Blanchot sobre a morte:

É a morte inevitável, mas inacessível; é o abismo do presente, o tempo do presente com o qual não tenho relação alguma, aquilo em cuja direção não posso lançar-me, pois nela eu não morro, estou desprovido do poder de morrer, nela morre-se, não se para e não se acaba de morrer. ${ }^{167}$

Em Amada, tal acontecimento participa da operação do luto e da melancolia com os quais Sethe tem de lidar, nesse lapso que não está sujeito ao tempo e, portanto, jamais se fechará, não importa o que se faça. A partir daí, assume-se que, para além dos corpos que somos, dos processos biológicos, psicológicos, sociais, políticos, estéticos e éticos que nos atravessam, vindos de muitos lugares e de outras épocas e eras, há um viver incorporal em nós. As sociedades humanas estão repletas desses

\footnotetext{
165 ZOURABICHVILI, 2016, p.118-119-145.

${ }^{166}$ DELEUZE, 2009, p. 10.

${ }^{167}$ BLANCHOT, M. O espaço literário. Tradução de Álvaro Cabral. Rio de Janeiro: Rocco, 2011. p. 168 .
} 
conjuntos de acontecimentos incorpóreos que se entrecruzam com os incorporais de cada um. E tais trilhas de pensamento, como as trilhas de animas da narrativa Ikpeng, me levam de volta à experiência do caçador ameríndio: sua absorção mortal é uma pluralidade que se manifesta como singular, na mesma medida em que o "iwompin Enoy", cujo sufixo pin se traduz como estado passado e futuro, trata de um acontecimento que não é nem pessoal nem particular. Livre das limitações de um estado de coisas, o quase encontrar Enoy (o devir mulher de uma sirene) é um acontecimento latente na floresta.

Gostaria de pensar que, também nesse ponto, a morte conecta a experiência Ikpeng à experiência artística em Amada. É nesse sentido que, pelas diferenças entre seus incorporais, cada um transmitindo um quase encontro particular com a morte uma estranheza, uma exposição ao risco, uma condição de estar perdido na floresta -, caminho entre essas narrativas reconhecendo-as também pela dicção deleuzeana de acontecimento:

A morte é ao mesmo tempo o que está em uma relação extrema ou definitiva comigo e com o meu corpo, o que é fundado em mim, mas também o que é sem relação comigo, o incorporal e o infinitivo, o impessoal, o que não é fundado senão em si mesmo. É por aí que a morte e seu ferimento não são um acontecimento entre outros. Cada acontecimento é como a morte, duplo e impessoal em seu duplo. ${ }^{168}$

Ilumina-se assim a concepção de que somos o que nos acontece e somos os acontecimentos enigmáticos e limítrofes que estão na própria superfície do corpo e englobam todos os outros corpos (humanos ou não). Acontecimentos que vivem um presente instantâneo, inconstante, um tempo de devir. Em modificação permanente, promovem a concomitância de mundos. Assim, minha ferida, para Deleuze, seria a quase-causa da cicatriz que acontece aos outros. Uma vez deslocados para a dimensão inventiva, tais acontecimentos provocam um estado de suspensão do pensamento e das sensibilidades calcificadas, remetendo a uma forma de vida (vida-morte) de que não conseguem dar conta, mas sem a qual não teriam verdade.

${ }^{168}$ DELEUZE, 2009, p.154. 
Ainda quanto à cicatriz de Sethe mais propriamente, não seria um disparate pensar que ela funcione também como o próprio monumento artístico do modo como Deleuze e Guattari concebem esse conceito fundamental, tomando-o como sendo um composto: "[a] arte desfaz a tríplice organização das percepções, afecções e opiniões, que substitui por um monumento composto de perceptos, de afectos e de bloco de sensações que fazem as vezes de linguagem." 169 . Esse composto "não comemora, não celebra algo que se passou, mas transmite para o futuro as sensações persistentes que encarnam o acontecimento: o sofrimento sempre renovado dos homens"170. O monumento ocupa, assim, um lugar paradoxal na arte: no livro de Morrison, a cicatriz ganha a dimensão escultórica de um fóssil vivo e movente.

Amy agora diz:

"Melhor assim? Nossa, que jeito de morrer. Você vai morrer aqui, sabe? Não tem saída. Agradeça ao seu Criador eu ter aparecido para você não ter de morrer lá fora no mato. Vem uma cobra e pica você. O urso come você. Quem sabe você devia ficar é lá onde você estava, Lu. Estou vendo pelas suas costas porque não ficou, ha-ha. Quem plantou essa árvore aí deixa mr. Buddy lá para trás. Que bom que eu não sou você. Bom, só dá para usar teia de aranha (...). Quem sabe eu abro esses botões aí. Faço sair esse pus, não acha? (...)

Sethe ouviu enquanto ela se afastava cantarolando pelo mato procurando teias de aranha. Um cantarolar em que ela se concentrou porque assim que Amy saiu o bebê começou a se esticar. (...) Amy voltou com dois punhados de teias, que limpou de presas e depois usou para cobrir as costas de Sethe, dizendo que eram como enfeites numa árvore de Natal. (...)

"Você ainda não morreu, Lu? Lu?"

"Ainda não."

"Faço uma aposta com você. Se aguentar esta noite, você aguenta o resto todo." (...) "Você não me morra esta noite, está ouvindo? Não quero ver a sua cara preta e feia em cima de mim me assombrando. Se morrer, você trata de ir para algum lugar onde eu não veja você, ouviu?". (...)

Sethe nunca esperou ver mais nada neste mundo, então quando sentiu dedos tocando seu quadril levou algum tempo para sair de um sono que pensou ser a morte. Sentou-se, o corpo duro e trêmulo, enquanto Amy olhava suas costas sumarentas. ${ }^{171}$

A ênfase dessa passagem está em um prenúncio contido desde o começo, no embate com a quase morte que acontece ali. Esse embate, que se dilui nas "costas

\footnotetext{
${ }^{169}$ DELEUZE; GUATTARI, 2010, p. 208.

${ }^{170}$ Ibid., p.209.

${ }^{171}$ MORRISON, 2007, p.115-118.
} 
sumarentas", evoca uma pausa para ouvir o cantarolar de Amy: "ela se concentrou porque assim que Amy saiu o bebê começou a se esticar". E o movimento que se segue marca o grito mudo do feto pela vida. Um grito no esticar-se. Uma vida inaudível a ser escutada. Mas Sethe agoniza, está em vias de morrer. Uma morte que não se efetua, mas insiste na efemeridade da vida. Na insistência desse acontecimento vai se construindo o devir feiticeiro da narrativa.

A partir da estratégia performativa de um modo de narrar que poderíamos dizer xamânico, insiste esse modo de subsistência da morte com o qual posso experimentar minha própria posição de "eu". Esse procedimento fica evidente quando a narração xamânica, ao mesmo tempo em que é enunciada, provoca um efeito suspensivo no fluxo do discurso, a partir do tom de voz soturno de Amy. Trata-se de uma voz grave que sai de uma boca cujo hálito quente é um bafo de "madeira queimando". Boca que, embora cantarolando sem alegria, me prende a um fluxo discursivo de afetividades as quais me mantêm embaraçada, suspensa e a um passo de.... Num trabalho de pesquisa, talvez não seja apropriado, mas tenho de falar aqui que experencio minha voz embargada na voz soturna de Amy.

A força dessa voz narrando a quase morte é o que desorienta, possibilita a expressividade orgânica e simultânea de realidades dolorosas vindo à tona, desorganiza certezas e altera o fluxo de sentidos no mundo dos vivos. O efeito suspensivo da narrativa expõe a véspera da morte, uma véspera infinita para os que têm a vida expropriada em permanente situação degradante.

Nessa sondagem de sensibilidades que compõem a morte em Amada - quaseacontecimento e fóssil vivo composto por bloco de sensações como querem Deleuze e Guattari -, qual seria a participação do estado de véspera xamânico e o que ele faz, numa aventura sensível em que o xamã não é senão o corpo impessoal por onde passam todas essas forças? Se olhássemos o mais longe possível, buscaríamos essa resposta, mais uma vez, entre os Ikpeng e poderíamos dizer com esse povo que tal véspera age como muitas pequenas mortes intercaladas na vida, acontecimentos que envolvem estados de intoxicação: "Morre-se (irompo) durante pesadelos, desmaios, febres 
agudas, intensa atividade de dança e canto, convulsões epiléticas, tonteiras causadas por grande perda de sangue, embriaguez e transe xamânico."172

Em seus estudos acerca dos Ikpeng, David Rodgers deixa claro que o xamã não existe em si, mas "funciona como uma quase-topologia de conexões e recapturas que compõem e contêm uma população local" ${ }^{173}$. O devir da narrativa em Amada encena movimentos de morte e de vida, marcando nesses movimentos uma topologia e instaurando uma véspera da morte que atravessa misteriosamente o corpo xamânico para dar subsistência a uma cicatriz: uma pele sobrevivida e compartilhada no espaço de um pensamento que nunca se completa. De outro lado, ainda entre os Ikpeng, o xamã é visto também como uma anomalia de espécie por sua exposição excessiva à morte, o que envolve o consumo da bebida-dos-espíritos. Portanto, o xamã se insinua como sendo, nos termos de Deleuze e Guattari, um anômalo múltiplo.

Para a dupla de filósofos, "uma multiplicidade se define, não pelos elementos que a compõem em extensão, nem pelas características que a compõem em compreensão, mas pelas linhas e dimensões que ela comporta em 'intensão""174. E mais: toda multiplicidade tem seu "anômalo", como é a baleia Moby Dick (destacandose de todas as outras baleias) para Ahab, o que não pressupõe sujeito e objeto diferenciados nem tampouco uma estrutura centrada, mas antes uma borda. São devires que se deixam compreender sob o signo do quase. Dizendo de outro modo, torna-se impossível a objetivação da realidade tanto para o observador quanto para o observado. Nesse sentido, observar um corpo morrendo é um ato embriagado de abertura para a morte.

Em Amada, o artesanato discursivo se realiza em vários tons e por múltiplas vozes. Pela via dessas vozes e tons que compõem a enunciação, evidencia-se o corpo aberto de Amy em sua mais longínqua alteridade até quase perder-se numa rarefação que emudece. Tal abertura faz com que Amy seja ela mesma observada pela morte para que, vencida a mudez, abandone a possibilidade de um discurso coerente e só então assuma o papel de contar o que viu com "voz de sonâmbula". Reconheço aqui uma

\footnotetext{
${ }^{172}$ RODGERS, David. A soma anômala: a questão do suplemento no xamanismo e menstruação Ikpeng. In: Mana. v. 8, n. 2, p. 91-125, 2002. p. 91-125.

${ }^{173}$ RODGERS, 2013, p. 77-105.

${ }^{174}$ DELEUZE; GUATTARI, 2012, p. 28.
} 
inusitada aproximação entre o sonambulismo da narração de Amy e a linguagem sonâmbula de G.H.: "Precisarei com esforço traduzir sinais de telégrafo - traduzir o desconhecido para uma língua que desconheço, e sem sequer entender para que valem os sinais. Falarei nessa linguagem sonâmbula que se eu estivesse acordada não seria linguagem"175.

A partir do mundo de Amada, penso, portanto, que é fértil conjugar aqui a leitura dos estudos etnográficos de David Rodgers com a "A morte como quase acontecimento” de Viveiros de Castro. Segundo este último, alguns mitos indígenas que contam o porquê de os humanos terem uma vida limitada possuem, com algumas variações, basicamente o seguinte enredo:

Havia um tempo em que uma divindade avisava aos índios que ouvissem apenas o apelo dos espíritos das árvores de madeira dura, aquelas que não apodrecem. Caso contrário, a morte aconteceria. Por pura contingência, certa vez alguém confundiu as coisas e, atrapalhando-se, respondeu à interpelação das árvores de madeira mole. Portanto, os humanos não são culpados da própria morte como o são aqueles que cometeram o pecado original de acordo com o mito bíblico. Para os ameríndios, os humanos morrem por conta apenas de um engano, enquanto que outros, como as aranhas e as cobras, por terem atendido ao apelo de outras árvores, possuem vida longa, bem como a resistência e a dureza da essência dura. ${ }^{176}$

No caso dos Ikpeng, tanto em episódios de vidência ou cura - quando o xamã procura e recaptura a alma capturada de seu paciente - quanto no sonho - quando a alma vaga no mundo dos espíritos hostis -, registram-se antecipações menores, isto é, estados de véspera da morte final. Em Amada, a estratégia relacionada à personagem Amy evidencia esse aspecto de tensão entre o emprego maior (dominante) e o emprego menor (alucinatório) da narrativa.

A experiência de contato com a morte, que nos é oferecida pela atuação de Amy, situa-se contra a lógica de condenação de morte aos marginalizados (humanos ou não). Sethe tem uma chance de vida porque Amy a está avisando dos perigos contingentes do mundo: “(...) para você não ter de morrer lá fora no mato. Vem uma cobra e pica você. O urso come você". De outro lado, o espaço ficcional ocupado pela atuação de

\footnotetext{
${ }^{175}$ LISPECTOR, Clarice. A paixão segundo G. H. Rio de Janeiro: Francisco Alves, 1990. p. 25.

${ }^{176}$ VIVEIROS DE CASTRO, 2009a.
} 
Amy na mesma passagem, sugere a resistência diante da morte. Uma resistência tornada possível pela intervenção xamânica em aliança contranatural com teias de $\operatorname{aranha}^{177}$. Uma aliança cujo elemento é o devir que não anula partições organizadoras (por exemplo, humano e animal), mas, ponto de vista sobre ponto de vista, atua no sentido de pôr em questão a violência sofrida por multidões.

Porque a linha de embate contra a morte ali é outra. Trata-se de uma violência que é criação humana tanto quanto é criação humana uma árvore de Natal. Nessa expressividade repleta de hesitação entre um nós e um fora (entre árvore de Natal e aliança contranatural), inscrevem-se os corpos de Amada (a filha morta que emergiu do rio e estava faminta de "saber"); de Denver (a irmã sobrevivente que via e sentia por meio de Amada, alimentando o interesse da irmã morta, e que vai lançar luz à perspectiva da mãe); de Sethe (que se apropria das energias de Amy em aliança contranatural com teias de aranha que eram como enfeites numa árvore de Natal).

Forças sensíveis, como as que aqui se apresentam, são recorrentes no pensamento nietzschiano, assim como o são as teias de aranha, convocadas algumas vezes como imagem crítica pelo filósofo. É importante destacar, por exemplo, a discussão nietzschiana empreendida em torno do saber científico que atua como prolongamento dos interesses do corpo no qual os humanos se abrigam e se protegem. Na aproximação perspectivista que faz do Ocidente e em sua crítica do conhecimento que se queira absoluto, o filósofo convoca e desloca o poder figurativo da aranha, desabitua os lugares metafóricos que costumamos atribuir-lhe: a teia de aranha pode ser usada em analogia metafórica para elogiar a teia de conceitos da ciência, se considerarmos, por exemplo, a sua "virtude" arquitetural. Podemos pensar em outros termos com Nietzsche:

\footnotetext{
177 Sabemos que indígenas utilizam a teia de aranha para a cicatrização de ferimentos, o que serve de inspiração para pesquisas científicas no mundo ocidental. Exemplos dessas pesquisas em <https://www.dw.com/pt-br/m\%C3\%A9dicos-empregam-teias-de-aranha-na-cirurgia-reconstrutiva/a16454823>; e <http://usp.br/aun/antigo/exibir?id=2624\&ed=367\&f=15>. Acessos em: 16 mar. 2020.
} 
Pode-se muito bem, aqui, admirar o homem como um poderoso gênio construtivo, que consegue erigir sobre fundamentos móveis e como que sobre água corrente um domo conceitual infinitamente complicado: - sem dúvida, para encontrar apoio sobre tais fundamentos, tem de ser uma construção como que de fios de aranha, tão tênue a ponto de ser carregada pelas ondas, tão firme a ponto de não ser espedaçada pelo sopro de cada vento. ${ }^{178}$

Evidentemente, ao trazer as teias de aranha para o campo do conhecimento, ao sublinhar que, como a aranha, tecemos os nossos conceitos de nossa própria substância, o jovem Nietzsche nos dá apenas um exemplo de uma estratégia poético-crítica mais ampla; a esta altura, ele afirmava que as nossas supostas verdades são metáforas que tiveram sua força sensível desgastada, cabendo ao filósofo inventar contra-metáforas irreverentes. Procuro aqui tão somente usar o pensamento de Nietzsche para chamar atenção ao modo analogicamente subversivo como a narrativa de Amada recorre às teias de aranha, metáfora exaustivamente usada no contexto literário. E é no tratamento literário de modos de existência em quasidade, no limiar do eu ao outro e do outro no outro, que a narrativa de Morrison também convoca tal metáfora, deslocando-a da acepção tradicional, buscando para ela um efeito que causa estranhamento no mundo interpretado/vivido pelos ditos ocidentais.

Proponho que continuemos a considerar o devir feiticeiro de Morrison, cuja força, além de operar pela sua simples enunciação, está também em apresentar certos tipos de relações (entre mortos e vivos, corpos e espíritos, humanos e não humanos) muito mais complexas que a simples troca verbal, se pensada como algo que existe de modo separável de seu entorno. Relações que se deixam afetar pela troca entre energias imagéticas e forças mágicas da vida. Podemos citar a passagem em que Sethe rememora o que aconteceu no momento em que os caçadores de escravos chegaram para recapturá-la e a seus filhos:

\footnotetext{
${ }^{178}$ NIETZSCHE, Friedrich. Sobre verdade e mentira no sentido extra moral. In.: Obras incompletas. Tradução: R. R. Torres Filho. São Paulo: Abril Cultural, 1978. p. 49.
} 
Simples: ela estava de cócoras no jardim e quando viu eles chegando, e reconheceu o chapéu do professor, ouviu asas. Pequenos beija-flores espetaram os bicos de agulha em seu pano de cabeça até o cabelo e bateram as asas. E se ela pensou alguma coisa foi: não. Não. Nãonão. Nãonãonão. Simples. Ela simplesmente correu. Recolheu cada pedaço de vida que tinha feito, todas as partes dela que eram preciosas, boas, bonitas, e carregou, empurrou, arrastou atrás do véu, para fora, para longe, lá onde ninguém podia machucálos. Lá longe. Fora deste lugar, onde eles estariam seguros. E as asas dos beija-flores continuaram batendo. ${ }^{179}$

Ouvem-se as asas dos beija-flores. A partir deles, do seu chamado vindo do bater incessante de asas e do espetar de bicos de agulha na cabeça, Sethe se desestabiliza e decide que não permitirá que seus filhos sejam levados de volta à escravidão. Nesse sentido, como formas de vida diferentes que coalescem, a negativa ininterrupta no pensamento de Sethe encontra o contínuo bater de asas, voltando-se ambos para o ato de procurar uma saída. Em linhas gerais, a saída ganha a conotação de voo para um mundo possível fora dali. A partir da escuta misteriosa de um bater de asas, uma mãe resolve recolher "cada pedaço de vida que tinha feito": no livro de Morrison, os beijaflores se tornam corpos pensantes e operadores de um turbilhão no pensamento de Sethe. A ênfase da narrativa que se seguirá está no ato performático da protagonista em tentar matar os filhos para dar-lhes uma realidade alternativa.

\section{2.}

\section{...nós, as bocas: $O$ imitador de vozes, de Thomas Bernhard}

Cabe agora trazer aqui a dinâmica dos movimentos performáticos de Thomas Bernhard em O Imitador de vozes, na tradução de Sérgio Tellaroli, como mais uma imaginação de quase acontecimentos que mobilizam vínculos móveis entre um outrar e um morrer. Os tais movimentos, que nos chegam com esse livro de contos, manifestam-se por um absurdo.

Interesso-me aqui pela pergunta: o que é - e como - levar a sério o absurdo que $O$ imitador de vozes lança sobre nós ao abordar acontecimentos trágicos com a narrativa característica das notícias de jornal e dos relatos cômicos das mesas de bar? Ao contrário daquilo que caracterizaria a veiculação de uma notícia - a transmissão

${ }^{179}$ MORRISON, 2007, p.221-222. 
de informações baseada exclusivamente na coerência —, o livro de Bernhard acontece na esteira de uma absurdo lógico: em um movimento muito afim aos absurdismos de Samuel Beckett, cujo fazer artístico-pensante mereceu a admiração do escritor.

No contexto desta pesquisa, gostaria de começar minha abordagem debatendo o sentido com que concebemos (nós, ditos ocidentais) a imagem de seriedade, o nosso emprego da seriedade numa economia de importância, emprego ao qual reservamos (nós, ditos modernos) um caráter grave ao domínio dos fatos. Essa gestão da seriedade, em oposição àquilo que a comodidade do senso comum estabelece como sendo produto da imaginação, é um dos traços pretensiosos da grande tradição representacionista ocidental que faz com que, num sentido culturalmente relevante, não se levem a sério escritas artísticas tanto quanto se levam a sério tratados científicos ou filosóficos. Aproximando aqui a precária condição de seriedade reservada à arte da maneira como a vida e o pensamento ameríndios são considerados desimportantes, retomo Eduardo Viveiros de Castro que diz: "como é que alguém poderia não levar a sério uma vida? Qualquer vida?"180.

Surge assim uma outra pergunta: como levar a sério uma narrativa mítica ameríndia ou uma prática xamânica? Levar a sério não exclui o humor: pode mesmo significar saber como rir verdadeiramente com os índios e não dos índios. Implica, em todo caso, ir além de apenas achar as narrativas indígenas curiosas e interessantes, mas descartáveis. De fato, o nosso primeiro impulso é o de domesticar a comicidade dessas narrativas, procurando dar-lhes uma dimensão lógica em que as palavras representam pensamentos autônomos segundo uma realidade universal. De outro lado, a possibilidade de levar a sério um absurdo, tendo em vista a barreira do entendimento, pode ser vista como cair no abismo, na loucura, no relativismo total, com consequências éticas, ontológicas e epistemológicas que podem ser vividas como muito aflitivas.

Ao elaborar a tese do perspectivismo ameríndio, transcriando etnofilosoficamente a imaginação conceitual de coletividades nativas americanas, Viveiros de Castro franqueia uma terceira via, um caminho “ortogonal à oposição entre

\footnotetext{
${ }^{180}$ VIVEIROS DE CASTRO, Eduardo. The Nazis and the Amazonians, but then again, Zeno. In: Symposium on Comparative Relativism. Copenhagen: IT University, September. 2009. p. 10.
} 
relativismo e universalismo" 181 . Tal transcriação corresponde ao exercício de fazer uma experiência de pensamento com o pensamento alheio. Tal exercício desloca concepções de seriedade empregadas segundo um viés "etnocêntrico", mesmo por aqueles que recusam o universalismo, mas consideram o etnocentrismo como uma condição inescapável, como é o caso do filósofo Richard Rorty, para quem o intelectual liberal do ocidente "simplesmente não tem como levar a sério" 182 visões como as dos povos da Amazônia. Para Viveiros de Castro,

isso que Rorty declara ser impossível de levar a sério vem a ser exatamente o objeto da antropologia. A antropologia é "simplesmente" aquele empreendimento intelectual ocidental que se dedica a levar a sério aquilo que os intelectuais ocidentais não podem levar a sério. $\mathrm{Ou}$, melhor dizendo, a antropologia é o empreendimento que leva a sério a questão de como levar a sério uma série de "visões" - não no sentido de "crenças", isto é, de visões consensuais, mas no sentido de mundos vistos objetivamente; não outras visões de mundo, mas outros mundos de visão, outros mundos visíveis. ${ }^{183}$

Aqui se insinua também a diferença de projeção social e política de um xamã perante sua tribo e a projeção de um artista perante o Ocidente etnocêntrico. Enquanto, entre nós, lhes é negado esse sério interesse, escritores e leitores, xamãs e a gente da tribo para quem eles contam histórias, enfim, aqueles que se expõem ao modo artístico de estar no mundo são levados a dar passagem às perspectivas que se multiplicam mediante o acontecimento poético. Essa multiplicação acontece porque o acesso a um limiar de sentido não é um caminho para se chegar a um lugar determinado, específico, mas o próprio acontecimento. Inevitável aqui invocar Jean-Luc Nancy e seu "Fazer, a poesia". Nele, o pensador defende a poesia não meramente como gênero, mas como acontecimento: algo da ordem de um fazer que pode ser encontrado tanto num verso ou numa narrativa, como numa árvore, numa montanha, na natureza. Nancy insiste em alguma coisa que a poesia $f a z$, sendo essa alguma coisa a própria dificuldade do fazer: “difícil é o que não se deixa fazer, e é isso o que propriamente a poesia faz. Ela faz o difícil. (...) A poesia faz a facilidade do difícil, do absolutamente difícil. Na facilidade,

\footnotetext{
${ }^{181}$ VIVEIROS DE CASTRO, 2002a, p. 347.

182 RORTY, Richard McKay. Objectivity, relativism, and truth: philosophical papers. Cambridge University Press, 1991. p.29.

${ }^{183}$ VIVEIROS DE CASTRO, 2009b, p.5.
} 
a dificuldade cede."184. Não se trata de dizer que o difícil desaparece, mas que estamos empenhados nessa experiência de dificuldade. "De repente, de modo tão fácil, encontramo-nos no acesso, quer dizer, na dificuldade absoluta, "elevada" e "tocante". ${ }^{185}$ Nancy acredita que esse acesso se realiza a partir do acontecimento poético que "faz tudo falar, que depõe todo o falar nas coisas"186. Assim, o acontecimento poético seria ao mesmo tempo a convocação para uma experiência de escuta de outros modos de falar em outros mundos capazes de deslocar as interpretações que fazemos das coisas.

Se, por outro lado, o termo "poesia" deriva do grego poiesis, cujo significado original é o verbo "fazer", faz-se esse difícil que passa a existir em "O imitador de vozes", conto de Bernhard no livro de mesmo título.

Convidado de ontem à noite da Sociedade Cirúrgica, O imitador de vozes, depois de se apresentar no Palais Pallavicini a convite da própria Sociedade Cirúrgica, já havia concordado em se juntar a nós na Kahlenberg para, também ali, na colina onde mantemos uma casa sempre aberta a todas as artes, apresentar seu número, naturalmente não sem pagamento do cachê. Entusiasmados com o espetáculo a que tínhamos assistido no Palais Pallavicini, pedimos ao imitador de vozes, natural de Oxford, na Inglaterra, mas que frequentou escola em Landshut e exerceu de início a profissão de armeiro em Berchtesgaden, que, na Kahlenberg, não se repetisse, mas apresentasse algo inteiramente diverso do mostrado na Sociedade Cirúrgica, ou seja, que imitasse na Kahlenberg vozes inteiramente diferentes daquelas imitadas no Palais Pallavacini, o que ele prometeu fazer. E de fato o imitador de vozes imitou na Kahlenberg vozes inteiramente diferentes daquelas apresentadas na Sociedade Cirúrgica, algumas mais, outras menos famosas. Pudemos inclusive fazer pedidos, aos quais o imitador de vozes atendeu com a maior solicitude. Quando, porém, no final, sugerimos que imitasse sua própria voz, ele disse que aquilo não sabia fazer. ${ }^{187}$

O narrador de Bernhard imagina a perda de identidade de um imitador. Mas o que dizer do papel do corpo nessa experiência de imaginar? Como convidado de cerimônias em palácios e sociedades médicas, o personagem é instigado a imitar vozes mais ou menos famosas. De maneira tal que todas as vozes que o imitador faz falar tão

${ }^{184}$ NANCY, Jean-Luc. Fazer, a poesia. In.: ALEA. Tradução de Mauricio Cardozo. v. 15/2, 2013. p. 417.

${ }^{185}$ Ibid.

${ }^{186}$ Ibid., p.415.

${ }^{187}$ BERNHARD, Thomas. O imitador de vozes. Tradução de Sérgio Tellaroli. São Paulo: Companhia das Letras, 2009. p.11. 
perfeitamente são marcadas por uma escuta às naturezas das coisas (naturezas, no plural, é bom frisar, já que é de um multinaturalismo que se trata aqui). Ao imitar as vozes alheias, aquelas que, dentro de uma mesma espécie, a nossa, são tomadas como distintivas e privativas de cada corpo, o estrangeiro vindo de Oxford transita, pode-se dizer, entre naturezas. As vozes, tomadas na sua materialidade, tomadas elas mesmas como coisas e não na sua suposta missão de transportar pensamentos, falam por si. Este é também um modo de "depor todo o falar nas coisas" ${ }^{188}$. Por isso, mais do que um questionamento da perda de identidade de um imitador, o conto deixa latente que a arte de narrar pode se tornar um espaço em que o acesso a um limiar de sentido não se encontra na intenção de quem narra, mas se volta para aquilo que as naturezas das coisas outras e das vidas outras podem falar por si, diante do estado de quasidade. Quase perder a própria voz, o próprio corpo: uma experiência que, por assim dizer, estala na pergunta insidiosa com que somos deixados: afinal, com que voz o imitador disse que não saberia imitar a própria voz?

A quasidade é também o arrebatamento do acontecimento poético no corpo da narrativa de $O$ imitador de vozes. O quase faz da arte de narrar um caso singular desse arrebatamento. É preciso dizer com Walter Benjamin que a arte de narrar é aquela que beneficia o relato em detrimento de "explicações" ${ }^{189}$. Desse modo, a narrativa artística conserva uma força de germinação, força que não se esgota e que é capaz de se desdobrar infinitamente, oferecendo, a cada vez, lugar para outras experiências.

Uma vez assim, pode-se ocupar o espaço deixado em aberto pela renúncia informativa da arte de narrar como uma possibilidade de levar a sério narrativas em que forças da diferença estão sempre atuando. Aquela atuação em esferas onde não se consegue colher o que é narrado apenas intelectualmente. Aquele lugar onde os esforços de ordenação inteligível não são suficientes e deixam ver toda sorte de relações sensíveis: entre as quais, aquelas com as árvores onde são colhidas as palavras das histórias contadas. É dessa maneira que vejo uma possível aproximação do

\footnotetext{
188 NANCY, 2013, p. 421.

${ }^{189}$ BENJAMIN, Walter. Pequenos trechos sobre arte. In. Rua de mão única. Obras escolhidas. vol. 2. Tradução de Rubens Rodrigues Torres Filho e Carlos Martins Barbosa. São Paulo: Brasiliense, 1987. p. 276.
} 
cruzamento de muitas vozes encarnadas na boca do imitador de Bernhard às muitas bocas nas "árvores de cantos" que os Yanomami denominam amoa hi:

As árvores de cantos estão nos confins da floresta, onde a terra termina, onde estão fincados os pés do céu, sustentado pelos espíritos tatu-canastra e os espíritos jabuti. (...) São árvores muito grandes, cobertas de penugem brilhante de uma brancura ofuscante. Seus troncos são cobertos de lábios que se movem sem parar, uns em cima dos outros. Dessas bocas inumeráveis saem sem parar cantos belíssimos, tão numerosos quanto as estrelas no peito do céu. ${ }^{190}$

É Davi Kopenawa quem narra o acontecimento poético das árvores de lábios moventes. Podemos dizer que é bastante notável o modo como o xamã as apresenta: é nelas que os espíritos xapiri vão colher as palavras de seus cantos para então transmiti-los aos xamãs. São cantos valiosíssimos, capazes de modificar o curso da vida. Para os Yanomami, essas árvores são visíveis apenas aos xamãs:

Transmito estas palavras pois eu mesmo vi, após nossos maiores, os inumeráveis lábios moventes das árvores de cantos e a multidão de xapiri se aproximando delas. Eu as vi de perto, em estado de fantasma, depois de meu sogro ter me dado de beber o pó de yãkoana. Eu ouvi mesmo suas melodias infinitas se entrelaçando sem parar! ${ }^{191}$

Aqui, não se pode deixar de experimentar a sensação de ser lançado para dentro da imensidão de uma vida surpreendente. Coisa de outro mundo. Como um performer, acostumado a testar as próprias barreiras corporais, Kopenawa enfatiza que habitar zonas de vizinhança entre mundos humanos e não humanos é um aspecto importante dessa experiência: a importância de habitar essa zona assim em suspensão ("em estado de fantasma"). Nesse estado suspensivo, que é também um modo artístico de estar no mundo, para o operador de mundos que é o xamã, as melodias vão se entrelaçando sem parar. Ele ouve entrelaçadas as melodias e as incorpora, dando forma aos sons ouvidos através das bocas de árvores, como modo de entrelaçar o próprio conhecimento a outros saberes.

\footnotetext{
${ }^{190}$ KOPENAWA; ALBERT, 2015, p.114.

${ }^{191}$ Ibid., p.115.
} 
As palavras dos cantos que os xamãs aprendem com os lábios moventes das árvores são modos de ser, formas de vida que eles aprendem: vida radicalmente múltipla acionada em seu movimento pela consistência desse modo artístico de estar no mundo atravessado pelo desejo de encontro com a alteridade. Nesse contexto, pensase e vive-se a alteridade não como uma ordem exterior a outra ordem que se toma como igual a si mesma, mas toda ordem é já diferente de si mesma. Neste ponto, vale destacar o que diz Eduardo Viveiros de Castro sobre o processo do desejo nas sociedades amazônicas, onde os seres, definidos por sua radical alteridade, são "objeto de um desejo igualmente radical por parte do Eu" ${ }^{192}$. E é por esse desejo de liberar um diferente no mesmo que acontecem os intercâmbios entre humanos e não-humanos, como em muitos dos encontros relatados por Kopenawa:

Esses xapiri são a imagem dos pássaros cujo canto melodioso ouvimos pela manhã e à noite na floresta. Assim é. Cada xapiri possui seus próprios cantos: os espíritos tucano e araçari, os espíritos papagaio, os espíritos da ararinha weto mo, os dos pássaros xotokoma e yõriama e todos os outros. Os cantos dos xapiri são tão numerosos quanto as folhas de palmeira paa hana que coletamos para cobrir o teto de nossas casas, até mais do que todos os brancos reunidos. Por isso suas palavras são inesgotáveis. ${ }^{193}$

Nessa realidade em que o desejo de alteridade é radical, um aspecto importante é o de que os Yanomami mantêm com a floresta uma relação tão histórica quanto imaginária. É nesse modo de vida que eles inserem as árvores de línguas sábias onde os espíritos pássaro buscam as palavras antes de fazerem suas danças de apresentação aos xamãs.

De outro lado, em formas de vida ocidentais, dissemina-se um anseio de alteridade. As vozes dos pensadores e artistas do nosso tempo, bem como nossos próprios corpos, dão sinais nítidos de que os riscos que vivemos têm a ver com a incapacidade ligada a uma confiança abundante num certo modo de conhecer, que leva a um tipo de desconhecimento. Nesse contexto, persistem, em esferas muito inadvertidas da nossa vida, a insidiosa e excessiva confiança do homem e sua fé na

\footnotetext{
192 VIVEIROS DE CASTRO, Eduardo. O medo dos outros. Revista de Antropologia da USP. São Paulo: n. 2, v. 54, 2011. p. 885.

${ }^{193}$ KOPENAWA; ALBERT, 2015, p. 114.
} 
certeza racional, fundamentos e pretextos para tantas exclusões, a saber: entre mito e filosofia, magia e ciência, selvagens e civilizados, arte e pensamento, ficção e teoria.

Fazendo retornar a história do xamã para essa circunstância que é a nossa, fica mais evidente a arrogância antropocêntrica. Por arrogância entende-se cegueira. E o xamã, enquanto narrador e possuidor da capacidade de ver o invisível, deixa de ser cego ao mesmo tempo em que deixa de ser simplesmente humano. A cegueira da consciência humana (cegueira da "gente comum" no modo de vida Yanomami) é destaque em algumas passagens da narrativa de A queda do céu, onde Kopenawa aponta o risco insuspeitável que correm os indígenas:

Gente comum não pensa nessas coisas. Quando vê chegar garimpeiros ou outros brancos, seu espírito permanece vazio. Contenta-se então em sorrir, pedindo comida ou mercadorias. Não se pergunta: "O que devo pensar desses brancos? O que eles vêm fazer na floresta? Serão perigosos? Devo defender minha terra e expulsá-los?”. Não, seu pensamento fica plantado em seus pés, sem poder avançar. ${ }^{194}$

É pela relação assimétrica que se trava com os brancos, a partir de dispositivos de captura de aparência cultural (comida e mercadorias), que a visão da "gente comum" é neutralizada. E, nesse sentido, Kopenawa acredita que a humanidade da floresta seja um dos aspectos visíveis e determinantes para a prática xamânica em sua conexão imaginativa com a vida:

Në roperi, a imagem da riqueza da floresta, se parece com um ser humano, mas é invisível à gente comum. Só deixa aparecer para seus olhos de fantasma o alimento que faz crescer, e apenas os xamãs podem realmente contemplar sua dança de apresentação. $\mathrm{Na}$ frente dela vem um bando barulhento de espíritos japim e gralha, acompanhado por uma multidão de espíritos arara, papagaio, tucano e mutum. ${ }^{195}$

Como nos conta o xamã Yanomami, espíritos do japim são um dos primeiros a acumularem os cantos que eles colhem em grandes cestos feitos de arumã. Essa passagem do relato é significativa pois pode ser tomada como medida para observar quão valiosos para o modo de vida Yanomami são esses efêmeros encontros com os

\footnotetext{
${ }^{194}$ KOPENAWA; ALBERT, 2015, p.114, p. 333.

195 Ibid., 2015, p. 208.
} 
espíritos dos pássaros, a partir de um diálogo transespecífico cujos interlocutores ativos são os xamãs. É através desses encontros que os xamãs trazem ao mundo novas possibilidades de mundo.

O xamã Kopenawa conhece de cor aquele movimento do querer dos pássaros pelas árvores. Em gesto análogo, artistas convocam vozes outras com as quais inventam possibilidades de mundo. O imitador de vozes do conto é um desses artistas e essa é a maneira de compreender o encontro com alteridades que gostaria de salientar no livro de Bernhard. Por sua vez, entre os inúmeros viventes da floresta, o japim é famoso pela capacidade de imitar. Ele imita o grito de outros pássaros e talvez por isso a graça e o ruído - que a materialidade de seu canto traz: "Arerererere”, “Kriii! Kriii! Kriii!” podem ser lidos como a vibração da complexidade enunciativa por excelência a partir do exercício perspectivista xamânico que, além disso, capta todos os sons da fala, não só as palavras. Acredito que os japins criam com os pássaros que imitam uma relação em que prevalece uma situação de quasidade, numa zona de indeterminação entre mundos possíveis. Trata-se aqui de compartilhar do ponto de vista de Deleuze e Guattari: de que "a arte que não espera o homem para começar"196. Trata-se, assim, de acreditar na vida de artista dos japins.

O artista da narrativa, seja ele xamã ou escritor, é aquele que pode ser muitos. Apenas sendo muitos é que se povoa artisticamente o mundo. Um intenso e heterogêneo povoamento com o qual se abre espaço para transformações relacionadas a modos de viver e de conhecer. Com isso, a partir de uma disposição simétrica no encontro com o outro, o artista espera romper com a postura neutra e transparente na produção de pensamento. Tomo simetria aqui nos termos do antropólogo Bruno Latour; ${ }^{197}$ trata-se de uma noção que constitui um ponto de peculiar tensão junto às discussões antropológicas na contemporaneidade para além do ambiente de especialização da disciplina e dos próprios limites acadêmicos. Essas discussões vêm

\footnotetext{
196 DELEUZE; GUATTARI, 2012, p. 136.

${ }^{197}$ O conceito de simetria é um esforço de Bruno Latour, dentre outros pensadores contemporâneos, no sentido de lidar com a questão da alteridade, livrando-se das assimetrias nas relações entre humanos e não humanos e friccionando as noções de natureza e cultura, simplificadas e pacificadas pelo relativismo. Fricção esta que alcançou um dos momentos mais vigorosos com o livro Jamais fomos modernos, quando Latour cunhou a expressão naturezas-culturas.
} 
se ampliando de modo a buscar a transversalidade entre saberes, misturando antropologia, filosofia, arte e literatura.

Na seriedade peculiar da escrita de Thomas Bernhard, é preciso reconhecer que os contos do livro $O$ imitador de vozes não se prestam a figurar como prosa naturalizadora de desigualdades e de ontologias; ao contrário, como é característico da arte forte, não apenas perturbam o território de uma pseudo-isenção quanto ao tratamento dos fatos, como tornam sensíveis forças ali represadas: eleva-as ao estatuto de fatos. Fatos de uma objetividade obscura - a obscuridade dos mundos em disputa — interceptam o narrador de Bernhard. Este narrador não conta histórias como quem observa uma célula por um microscópio, no sentido de uma experiência fechada de laboratório como um cientista que descreve uma realidade existente sem interagir com ela. Tampouco vitimiza ou positiviza personagens e ações. Tais personagens não são memoráveis ou glamorosos, mas indivíduos absolutamente comuns com os quais acontecem as coisas mais bizarras. Quanto a esse aspecto, acredito, porém, não se tratar simplesmente da apresentação de ideias bizarras, mas sim de deslocamentos da bizarrice no interior de formas de vida, de maneira a gerarem um choque suspensivo no leitor. Trata-se então de estratégia performativa.

Como parte da estratégia performativa de Bernhard em $O$ imitador de vozes, o narrador dos contos se veste ora de repórter, ora de testemunha ocular e auditiva, ora de mero contador de casos, para escrever o que pode ser lido como uma maneira de fazer tremer a "matéria velha"198 nas vozes das incontáveis bocas que germinam do projeto literário do escritor:

Teríamos de contemplar a existência como o estado de coisas que desejamos descrever, mas, por mais que nos esforcemos, o que contemplamos por intermédio do descrito nunca é esse estado de coisas. Uma tal constatação haveria de nos ter feito desistir há muito tempo de pretender escrever a verdade, o que significa que já deveríamos ter desistido há tempos da escrita em si. Como não é possível comunicar, ou seja, mostrar a verdade, nós nos contentamos em pretender escrever e descrever a verdade, bem como em dizer a verdade, mesmo sabendo que a verdade nunca pode ser dita. Do ponto de

\footnotetext{
198 Refiro-me aqui à divisa saussuriana "O que domina toda alteração é a persistência da matéria velha", que, em parte contra Saussure, faço incidir sobre o desejo de mudança de concepção da linguagem como código, sistema racional de representação, para uma compreensão da linguagem como forma de vida. Os interessados em renunciar teoricamente ao paradigma da representação e alinhar-se ao paradigma da práxis têm de conviver com todo um conjunto de práticas que favorece a visão representacionista.
} 
vista lógico, a verdade que conhecemos é a mentira que, incapazes que somos de contorná-la, se faz verdade. O que está sendo descrito aqui é a verdade, e, no entanto, não é verdade, porque não pode ser a verdade. Em toda a nossa existência de leitores, jamais lemos uma verdade, ainda que com frequência sejam fatos as coisas que lemos. O que lemos é, pois, invariavelmente a mentira como verdade, a verdade como mentira etc. Tudo depende do que queremos se queremos mentir ou dizer e escrever a verdade, ainda que jamais possa vir a ser verdade, ainda que jamais seja a verdade em si o que dizemos e escrevermos. Ao longo da vida, eu sempre quis dizer a verdade, embora saiba hoje que era tudo mentira. Em última instância, o que conta é apenas o conteúdo de verdade da mentira. A razão já me proibiu há muito tempo de dizer e escrever a verdade, porque fazê-lo é apenas dizer e escrever uma mentira, mas, para mim, escrever é necessidade vital, e é por isso mesmo, por esse motivo, que escrevo, ainda que tudo que escrevo nada mais seja do que mentira que por meu intermédio é transmitida como verdade. ${ }^{199}$

Essa intenção irônica de refletir sobre a questão da verdade está encenada em seu livro autobiográfico Origem, aqui em tradução de Sérgio Tellaroli. Da passagem acima citada, destaca-se: "Teríamos de contemplar a existência como o estado de coisas que desejamos descrever, mas, por mais que nos esforcemos, o que contemplamos por intermédio do descrito nunca é esse estado de coisas". A descrição tem aqui uma potência de alteridade e a ela se associa talvez à promessa de liberar forças rarefeitas, pois deixa em suspenso, sem explicar, algo que jamais se oferece com a paz de um estado de coisas apreendido.

Em linhas gerais, trata-se do convite para a realização de um empreendimento descritivo no lugar da explicação e da interpretação: escritores e artistas servem-se da descrição inventiva segundo uma dimensão performática. Da passagem acima citada, destaca-se ainda: “A razão já me proibiu há muito tempo de dizer e escrever a verdade, porque fazê-lo é apenas dizer e escrever uma mentira, mas, para mim, escrever é necessidade vital, e é por isso mesmo, por esse motivo, que escrevo.” Verifica-se aqui, de um lado, a disposição de Bernhard para romper com a concepção de linguagem como sistema presidido por uma racionalidade que alinha sistematicamente, entre outras reduções, palavra e coisa, som e sentido, significante e significado.

De outro lado, verifica-se sua determinação para (mais do que recusar) afrontar a concepção da linguagem como algo dotado de cidadania ontológica, como realidade

\footnotetext{
${ }^{199}$ BERNHARD, Thomas. Origem. Tradução de Sérgio Tellaroli. São Paulo: Companhia das Letras, 2006. p 243-244.
} 
existente por si, abstraída da práxis. Como Wittgenstein, uma influência importante em sua obra, Bernhard afronta tal concepção reconduzindo a linguagem do emprego metafísico e convencional para seu uso cotidiano e habitual, trazendo as palavras para o efeito que provocam nas histórias de nossas vidas. Isto é, para o que fazem, na prática, entre nós (não um nós absoluto, mas um nós que já comporta um eles; não um eles totalmente remoto, mas um outro no mesmo).

Nessa análise crítica feita por Bernhard, ele já sabe que as palavras não têm um sentido intrínseco, que, se essa for a régua para medir o sucesso da linguagem, ela é falha, não alcança a verdade das coisas e nunca chega às coisas mesmas. Contudo, reagindo especialmente à questão da verdade, situa-se para além de qualquer régua que permita aferir se cumpre sua vocação: a linguagem não tem vocação, é forma de vida. Bernhard se volta para a linguagem como necessidade vital. Uma necessidade que pode ser satisfeita através da escrita. Bernhard está apontando para um acontecimento outro da linguagem. Um acontecimento da ordem de um fazer (inevitável aqui invocar, mais uma vez, o fazer poético de que fala Nancy). Esse acontecimento reconduz à vida o jogo entre verdade e mentira: não é que não haja verdade e que não haja mentira. Mas que não haja verdade e mentira essenciais e absolutas, porém talvez perspectivas e móveis. Se são móveis, não são, no entanto, meramente convencionais ou relativas: comparecem na experiência vital com o mundo.

Em Investigações Filosóficas, Wittgenstein abre caminhos para, digamos, pensar a verdade da vida e a mentira da vida. Enquanto forças vitais, ambas não se deixam decidir pelo simples acordo entre os homens:

Assim, pois, você diz que o acordo entre os homens decide o que é correto e o que é falso? - Correto e falso é o que os homens dizem, e na linguagem os homens estão de acordo. Não é um acordo de opiniões, mas de forma de vida. ${ }^{200}$

Essa experiência encenada por Wittgenstein consiste em fazer com que possamos compreender/vivenciar que os acordos que têm lugar numa forma de vida não são acordos em torno de opiniões. Nesse contexto, se a escrita artística abala acordos, ela

\footnotetext{
200 WITTGENSTEIN, L. Investigações filosóficas. Bragança Paulista: Editora Universitária São
} Francisco: Petrópolis: Vozes, 2008. § 241. 
surge como potência de disrupção, que vai muito além das crenças, das visões de mundo, daquilo que podemos identificar, criticar, celebrar etc. Trata-se mais da possibilidade de fazer irromper no seio de uma forma de vida (exausta?) bocas de lábios moventes, bocas imaginadas, elas mesmas formas de vida, impossíveis de ser parafraseadas, explicadas, racionalmente compreendidas, conceitualmente apreendidas, controladas e capturadas em sua totalidade, não obstante sua força imensa. Uma força que é acionada em seu movimento vital pela promessa de um outro modo de estar no mundo.

O modo poético de fazer filosofia é levado a sério por Wittgenstein: "a filosofia deveria ser escrita apenas como uma forma de composição poética." ${ }^{201}$ Essa divisa faz jus à confessada valorização do registro da arte por parte do pensador desde que não se trate do domínio demarcado, de um gesto redutível em sua mecânica: a-histórico e atemporal. Penso que os contos de $O$ imitador de vozes encontram o caminho de sua performance como uma exploração inventiva de formas de vida. Gostaria de assinalar que há, nessa exploração inventiva, uma imbricação entre vida e imaginação, quando são mobilizadas forças contestatórias de quase contágio inevitável entre o lógico e o absurdo, num espaço refratário à paráfrase e à explicação. A manifestação dessas forças se dá em duas vertentes: de um lado, a atmosfera rítmico-visual das forças de deslocamento do absurdo encarnadas no modo de narrar. De outro, o espaço das forças indiscerníveis entre a coerência e o absurdo da narrativa disseminadas na escrita, na medida em que a "nossa" concepção de real está sendo requisitada por formas de vida que habitam outros reais.

Um encontro com outros reais pode acontecer, mais uma vez, a partir de Walter Benjamin. Ele chama a atenção para um aspecto importante da origem da construção da narrativa: o fato de o conhecimento assumir "pela primeira vez uma forma transmissível"202 a partir do interesse humano pela ocorrência da morte. Benjamin não está interessado em destacar o enredo da morte, mas as inúmeras imagens que afloram das expressões e olhares dos moribundos: "no interior do agonizante desfilam inúmeras imagens" 203 . No que diz respeito ao enredo dos 104 contos que compõem $O$ imitador

\footnotetext{
${ }^{201}$ WITTGENSTEIN, L. Cultura e valor. Lisboa: Edições 70, 1996. p.24.

202 BENJAMIN, 2012, p. 224.

${ }^{203}$ Ibid.
} 
de vozes, cada um ocupando em média o espaço de uma página, este enredo da morte é também menos importante que o modo de narrar. São historietas que se desenrolam na maior parte em pequenas localidades, cidades pitorescas do interior da Áustria, da Alemanha, da República Tcheca, da Noruega. Os fatos contados são triviais: viagens, encontros, caminhadas, lembranças, histórias ouvidas na rua. Quase sempre algo trágico acontece. Neste ponto, inspirada por Benjamin, proponho que nos concentremos na narrativa como um efeito do movimento de bocas captado para transmitir os acontecimentos imaginados. Entre os quais, a morte - constituinte principal:

Aconteceu-nos semana passada de cinco vacas, uma após a outra, lançarem-se contra o trem expresso no qual precisamos retornar a Viena, que as despedaçou por completo. Depois de os condutores e mesmo o maquinista, que viera correndo com uma picareta, terem limpado os trilhos, o trem seguiu adiante, após cerca de quarenta minutos parado. Pela janela, pude ver a empregada que, aos gritos, corria em direção a uma propriedade rural em meio ao crepúsculo. ${ }^{204}$

Este conto, cujo título é "A empregada", pode ser tomado como medida para observar as forças de deslocamento que atuam sobre a narração de uma série de fatos sombrios que acontecem ao longo do livro. Sublinha-se aqui a presença de uma cena de horror, o suicídio das vacas, fato que seria digno de paralisia por parte de quem a vislumbrasse, literalmente. Mas a engenharia da descrição transporta o despedaçar dos corpos para o final da frase - empurra-o para lá -, cristalizando a cena em objeto de um riso nervoso, um riso preso que não se escuta; no mesmo ato, preso e espalhado, dentro e fora do trem quarenta minutos parado no final de outra frase. Nesse mesmo ato, podese ouvir, do movimento plástico da narrativa, o seu efeito rítmico. É o efeito de uma música monótona cujo volume não se altera, nem mesmo o som dos gritos da empregada é capaz de fazer subir o tom da narração que nos desafia com sua seriedade escandalizante. Crispada pelo riso nervoso que não sai, não pode sair, a voz do narrador desloca-se do que seria o absurdo representado pela linguagem, fazendo surgir a força do absurdo em nós, as bocas..., de onde usualmente saem palavras de uma forma de vida exacerbadamente alheia ao que acontece ao outro.

${ }^{204}$ BERNHARD, 2009, p. 83. 
Desde as primeiras páginas de $O$ imitador de vozes, ela está lá: morte, morte e mais morte. Para usar um adjunto adverbial tão caro ao jogo de linguagem proposto por Bernhard e tantas vezes usado pelo narrador dos minicontos desse livro, naturalmente, o leitor passa então a evocá-la (a morte) e mesmo a procurar por ela a cada narrativa. Até que se chega ao conto cujo título é "Quase”. Contrastando com a sequência ameaçadora de relatos sobre alguém que morreu afogado ou que nunca mais voltou de uma viagem, sobre assassinatos a golpes de marreta e por estrangulamento, sobre suicídios com tiros na cabeça, o conto "Quase” evoca um outro tipo de morte:

Em nossa última excursão ao vale do Möll, onde sempre nos sentimos felizes, qualquer que seja a estação do ano, hospedados numa pousada em Obervellach que nos havia sido recomendada por um médico de Linz e não nos decepcionou, conversamos com um grupo de ajudantes de pedreiro que, terminado o dia de trabalho, ali se reuniu para cantar e tocar cítara, relembrando-nos assim dos inesgotáveis tesouros da música folclórica da Caríntia. Tarde da noite, o grupo de ajudantes de pedreiro veio sentar-se a nossa mesa, e cada um de seus membros tinha algo digno de nota ou lembrança a contar sobre a própria vida. Chamou-nos a atenção sobretudo o ajudante de pedreiro que relatou que, aos dezessete anos, para ganhar uma aposta feita com um colega, subira até a agulha da torre da igreja de Tamsweg, sabidamente bastante alta. Levei um tombo que quase me matou, disse ele, enfatizando expressamente que, por esse mesmo motivo, quase tinha saído no jornal. ${ }^{205}$

A fim de expor algumas peculiaridades do "Quase" de Bernhard, cabe antes dizer que, de acordo com a visão representacionista, há uma oposição entre a dita embriaguez maior da linguagem (afastada da realidade) e a dita lucidez maior da linguagem (próxima da realidade). Trata-se de oposições excessivamente fixas. Nas formas de vida tipicamente ocidentais, o estatuto da arte não é o da lucidez. Chamo atenção, portanto, para o seguinte aspecto: no reino da ficção, à maneira representacionista, sabe-se que a morte primordialmente deveria ser despertada de seu adormecimento sendo posta de modo a ser admirada pelo impacto de sua violência. Deveria sobretudo mostrar-se impactante de modo a exercer efeito persuasivo ou estético. Porém, no conto "Quase" parece que a morte hesita em aceitar o percurso de um controle absoluto da objetividade. O percurso não verbal dos quatro longos períodos que compõem essa escrita desautoriza qualquer tentativa de controle. O primeiro período, aliás,

${ }^{205}$ BERNHARD, 2009, p. 26. 
longuíssimo. A morte... volátil e heterogênea... Essa presença insuportável. Essa que não pode ser compreendida na lógica de que se reporta a um fora. Pelo que faz, essa morte não permite que se desvie da potência de sua respiração. Tendência que expressa a vida em potência da linguagem segundo o seu emprego.

O fôlego necessário à leitura do primeiro período do conto é a manifestação de que a morte ali pode estar vinculada a um jogo. A noção de jogo em Wittgenstein é o contraponto à noção de cálculo e faz o fluxo da linguagem desaguar na vida. Um jogo só existe se é jogado, sendo possível estimar os lances, contudo sem as garantias de um cálculo abstrato, no qual as regras já contêm em si, de antemão, todas as suas possibilidades de aplicação. É aí que a suspensão da vida diante da morte se dá. Seguese, pois, uma estimativa de lances no jogo da linguagem.

Por outro lado, em analogia com a leitura de Benjamin sobre Kafka, ali, no conto de Bernhard, as palavras sutilmente desabituadas se desdobram e remetem aos dois sentidos da palavra desdobramento em Kafka. Penso que a seguinte passagem de Benjamin pode expor o quero dizer aqui:

O botão "desdobra-se" na flor, mas o papel "dobrado" em forma de barco, na brincadeira infantil, pode ser "desdobrado", transformando-se de novo em papel liso. Essa segunda espécie de desdobramento convém à parábola, e o prazer do leitor é fazer dela uma coisa lisa, cuja significação caiba na palma da mão. As parábolas de Kafka, porém, desdobram-se no primeiro sentido, a saber como o botão se desdobra na flor. (...) Isso, porém, não impede que seus elementos não se ajustem inteiramente à prosa ocidental (...). Elas não são parábolas e nem querem ser tomadas como tais. ${ }^{206}$

A passagem em questão é para mim o sinal de uma associação da prosa kafkiana com o modo como a narração se insinua no "Quase" de Bernhard, o que pode ser percebido já na abertura do conto: ambos os casos (Kafka e Bernhard) não podem ser tomados como reduções metafóricas nem podem ser lidos no sentido literal.

A morte, já foi dito aqui, é o cerne das narrativas de $O$ imitador de vozes. Voltome então à morte do "Quase" para perguntar: qual o seu peso? Onde ela está? Vagueia como um fantasma? Algumas perguntas operativas, um embaraço e, neste ponto, percebo que a exploração desdomesticada dessa escrita dependerá de uma disposição

${ }^{206}$ BENJAMIN, 2012, p. 159. 
de me pôr a deriva junto com as frases e permitir que essas frases façam os limites de um mundo vacilarem. Uma frase é o que ela faz e o que se faz com ela. Mas e a vida? Com tudo isso, experimentá-las (morte e vida) não é nada confortável e pode ser traiçoeiro num certo sentido de que possa interferir no pensamento e na vida.

A escrita de Bernhard não é sistemática: tem o sentido de um fato, embora não pressuponha que cada fato tenha um sentido. A meu ver, os fatos narrados nessa escrita talvez remetam às palavras de Wittgenstein na seguinte passagem em que se reconhece a imprevisibilidade da linguagem que não se deixa assentar, supondo a renúncia física e espiritual a qualquer fundamento:

“É preciso não esquecer que o jogo da linguagem é dizer o imprevisível - isto é: não se baseia em fundamentos.

Não é razoável (ou irrazoável).

Está aí - como a nossa vida." 207

Nesse certo sentido - aquele que não se pode propriamente compreender quando se perde a noção do que está acontecendo -, o leitor é atraído pela radicalidade da experiência com a escrita de Bernhard sem sequer ter a chance de perguntar qual o motivo por trás da narrativa. Passa então a ser levado por ela, embora não saiba para onde. Nesta incursão que se pretende desdomesticada, também fui atraída, também fui levada a percorrer um traçado de forças sobre o qual direi a seguir algumas palavras tentando descrever o que vi por onde fui passando.

Logo de entrada, quanto ao seu traçado geral, vejo que não se trata da morte de um sonho ou da morte da esperança. Tampouco se trata da morte de uma época passada. Não é ainda uma morte hipotética, no futuro. Mas é inesperada e sem justificativa. Causa uma perplexidade que chega a ser constrangedora, funcionando como um susto, na medida em que estou sendo levada pela delicadeza de uma narrativa fluida, tranquila, numa linguagem prosaica, do dia a dia, cuja atitude é sóbria, porém estranha. Conduzida por ela, venho caminhando, naturalmente, deixando-me atravessar por palavras desimportantes precedidas por artigos indefinidos e, de repente, tropeço na quase morte do conto, a morte por um triz, aquela que por pouco não acontece e que só

${ }^{207}$ WITTGENSTEIN, L. Da certeza. Lisboa: Edições 70, 1990. §559. 
aparece ao final do texto. Uma morte que surge do nada, sem aviso nem parentesco, isto é, sem proximidade com algo que pudesse evocá-la. Até sua aparição, o narrador se dedica a compartilhar conosco suas experiências de férias, reproduzindo uma malha heterogênea de elementos narrativos resgatados da memória, independentes, dispersos e dissociados, conectando quase nada com quase nada que acontece. O narrador explora tal conjunto descontínuo de práticas a partir do passado impreciso de uma última excursão a um vilarejo austríaco, paisagem de montanha, "onde sempre nos sentimos felizes, qualquer que seja a estação do ano"; e continua contando que [nós] estivemos "hospedados numa pousada" a qual tinha sido "recomendada por um médico de Linz e não nos decepcionou". A essa altura, aparecem como personagens um grupo de ajudantes de pedreiro que se reunia para cantar e tocar cítara, "terminado o dia de trabalho". Numa dessas ocasiões, "tarde da noite", um dos ajudantes de pedreiro irá contar a sua experiência com a morte.

Em O imitador de vozes, do ponto de vista das forças indiscerníveis disseminadas nessa escrita, a morte pode se remeter a um cenário mais amplo e, nesse contexto, a narrativa tem um sentido coerente que beira o absurdo. Têm-se, portanto, alguns aspectos latentes. De um lado, esse sentido quase coerente/quase absurdo se encontraria bem guardado no mistério que é a experiência pessoal da morte. De outro, a própria compreensão-vivência da morte estaria submetida à impossibilidade da narrativa, pois é necessário morrer para ser apresentado ao sentido daquilo que não mais se poderá narrar. Insinua-se aqui um súbito avizinhamento entre o conto "Quase" e Amada, possibilitando que se diga mais uma vez que a morte só pode ser experimentada, precisamente em primeira pessoa, em sua quasidade. Possibilita dizer que Morrison e Bernhard estão investigando formas de absorção e articulação de um morrer no esforço especulativo de pensar quais são os problemas que surgem do confronto com a morte.

[Nós] "conversamos com um grupo de ajudantes de pedreiro": na ponta que inicia o fio da narrativa encontra-se a primeira pessoa do plural. Ela conduz a leitura. Pois bem, quase-nada, a morte não verbalizada exala sua presença de maneira imediata, comparecendo com veemência desde a primeira linha do conto, embora só se revele autoritária na ausência de trama da narrativa ao final do texto e à imagem dos quaseacontecimentos de um tombo e de uma notícia no jornal. [Eu] "levei um tombo que 
quase me matou": na outra ponta, uma singularidade, isto é, o índice de uma multiplicidade na boca do ajudante de pedreiro a quem sobra saúde e vigor para lidar com as forças selvagens da vida e, por isso, sobreviveu para contar. Sobreviveu para permanecer no anonimato, já que os valores do mundo ao qual pertence mantêm uma multiplicidade de vidas à margem dos acontecimentos dignos de virar notícia. Sejam aquelas vidas supostamente inferiores que desempenham profissões tornadas menores, sejam as daqueles seres animados e inanimados, feitos invisíveis, como as indomáveis vacas suicidas. Invisíveis pela cegueira antropocêntrica. Essas vidas em potência são oprimidas pelas regras do jogo da linguagem e estão condenadas a permanecer fora do mundo das páginas de jornal (leia-se também mídia eletrônica, redes sociais etc.). Caso pretendam fazer parte, precisam deixar de existir, de preferência, apoteoticamente, ao modo impactante do reino da ficção. Se assim for, talvez seja possível que as histórias dessas vidas deem um livro ou um filme. Talvez. Mas a vida de um ajudante de pedreiro, mais do que ajudar a compor obras de arte, pode atuar como uma convocação para a experiência artística propriamente. No cerne da experiência de quasidade da narrativa, Bernhard rouba do ajudante de pedreiro a palavra: um personagem que, diferente de outros do livro, não sofre um acidente, não é assassinado ou tenta tirar a própria vida. Esse é um personagem que participa de uma aposta. Participar de um jogo requer uma estratégia e uma performance. Daí surge a presença do quase, wittgensteinianamente em itálico. Mais do que pista, prova evidente manifestada na linguagem.

Sabe-se que roubar a palavra de trabalhadores não é exclusividade da escrita de Bernhard. Criaturas marginalizadas comparecem com igual vigor, para tirar da cartola um entre muitos outros exemplos possíveis, na narrativa de Arábia. Nesse filme, de Affonso Uchoa e João Dumans, o protagonista é operário de uma metalúrgica. A vida de Cristiano nos é apresentada a partir de um episódio de quase morte, quando ele sofre um acidente na fábrica e um garoto (igualmente à margem das condições impostas pelo mundo) encontra seus escritos. Quase morto no leito de um hospital, Cristiano é o vetor que permite aos diretores contar a história de quem trabalha duro na lavoura, fica desempregado, faz pequenos bicos, vai parar na prisão, mora em condições precárias até encontrar uma vaga numa metalúrgica e ali quase morrer. 
O acidente do trabalho que torna o operário narrador da própria história também o transforma no canal por onde irá transitar a direção do filme e, a partir daí, transmitir ao espectador a saga de um imenso contingente populacional violado todos os dias pelo sistema opressor.

Centrado apenas na última cena do filme, neste exercício de leitura, exploro a quase morte erguida das chamas que eclodem e das larvas que escorrem dos fornos da fábrica como uma liga metálica, para resgatar o quase encontro com a morte do caçador Ikpeng na floresta e a vida do ajudante de pedreiro no conto de Bernhard. Na cena do filme em questão, o personagem principal quase morto e liberto das ações do presente adentra o mundo dos sonhos:

\begin{abstract}
Naquela noite, sonhei comigo na mata, sonhei de novo o mesmo sonho que me acompanha há mais de dez anos, sonhei que estava sozinho numa floresta e ouvia de longe o barulho das pessoas me procurando, e parecia que eu tinha feito alguma coisa de errado, e me deitava, sozinho, e ficava muitos dias nessa mata. Com o tempo o barulho ia diminuindo e aos poucos as pessoas deixavam de me procurar e a noite toda só pensava uma coisa: eu estava vivo, e ainda podia respirar. ${ }^{208}$
\end{abstract}

Atenta a contiguidades possíveis entre os efeitos do quase morrer nas narrativas aqui consideradas, percebo o que se modificou em minha atenção. Segundo Eduardo Viveiros de Castro, a morte, configurada como quase-acontecimento, nos ajudaria, em parte, a reformular nossas posições sobre a dicotomia entre humano e não humano. Isso aconteceria no desconforto da quasidade que não se deixa dominar. Ponho em destaque essa observação do antropólogo para perguntar: será possível partir em outras direções?

Em termos de direito de viver, por exemplo, será o abolicionismo do sofrimento animal uma possibilidade no horizonte, considerando-se a necessidade de encontrar alternativa alimentícia viável, de curto prazo e em grande escala, que substitua a pecuária e a indústria processadora de proteína; e levando-se em conta que o próprio abolicionismo da escravidão humana demorou séculos para acontecer? Nesse sentido, seriam a quase morte e a quase vida propulsoras de reações concretas? Estas são questões operativas e, em princípio, não se encontram respostas satisfatórias.

${ }^{208}$ ARÁBIA. Direção de Affonso Uchôa e João Dumans. Ouro Preto, 2017. 
Além de tudo e ao menos até aqui, reconheço que assumir uma quasidade implica transitarmos entre pontos de vida móveis, entre os atos artísticos de escrever e de experimentar, entregando-nos às articulações narrativas das imagens e das palavras, aos entre-lugares da arte e do conhecimento, no encontro de saberes e não-saberes, num desejo apenas de quase-morrer, desejo também de narrar o estranho. Para além das estranhezas, como a morbidez da morte própria só poder ser vista no corpo do outro, o entrelaçamento das tramas se dissolve sob a quase morte que se conta. Dissolução coerente que pode ser traduzida no pânico que beira o absurdo diante do único fato incontestável da vida. Uma forma de vida atravessada pelo ideal da representação assentado justamente aí, nesse senso comum assim etiquetado: incontestável.

Mais absurdo então talvez fosse abrir mão da âncora dessa incontestabilidade, afastar-se dela. Absurdo e aflitivo. Sufocante demais. Se não for este o único fato incontestável, o que será de nós e da vida? Que vida? Nós, quem? Neste ponto, voltome para o fato de que, independente da clareza e da obscuridade da vida (sem causa, mas de igual efeito), se há outros mundos, haverá outras possibilidades de pensar-dizerviver-sentir.

Penso que, quando consideramos mundos outros e possibilidades outras, podemos dizer que estamos virando para outros lados e, até certo ponto, para arredores

próximos do perspectivismo ameríndio enquanto imaginação conceitual. Pois é sobretudo nos arredores das árvores de lábios moventes que a multiplicidade de bocas desabrocham e desdobram-se na expressividade de relações polifônicas capazes de alargar posições.

\section{3.} ...nós, os fantasmas: “Qvasi”, de Edimilson de Almeida Pereira

No campo dos estudos literários e no que concerne ao foco deste capítulo exercícios perspectivistas de leitura animados pela noção ameríndia de quasidade —, é potencialmente frutífero cruzar mais uma fronteira: desta vez, na direção do poema "Qvasi”, de Edimilson de Almeida Pereira. Fica claro, a partir do título, que o poeta pretendeu trabalhar com esse viés intermédio, essa posição (quam si) no meio de ou 
entre dois. Sendo esta uma posição reveladora da relação entre sentidos mais ou menos contrários, reivindica-se para o quase não um movimento no sentido de algo que virá, mas uma potência que arregimenta forças para uma encruzilhada com a qual se depara. É nesse contexto que as imagens poéticas de "Qvasi” fazem sentido para mim, levamme a um limiar do sentido, nos termos de Nancy. É nesse cenário que se torna importante, para esta pesquisa, um passo para o lado, especificamente procurando compreender como a quasidade fantasmal opera como um tipo de perspectiva das coisas estimulada por um fazer artístico criado na hora presente do Brasil.

Para isso, proponho nas páginas que seguem uma leitura de falares e saberes postos em relação a partir do exercício entre mundos franqueado por Edimilson. Tal exercício sempre condicionado ao outro e na perspectiva do outro, em composição com alguns de nossos fantasmas históricos, incorpora um sentido de país senhorial neste tempo em que vivemos, no mesmo gesto audacioso com o qual busca recolocar condições de existência.

"Qvasi” é o poema de abertura de uma coletânea homônima. Ao título da obra se acrescenta: “segundo caderno". Publicado em 2017, o livro é composto por 61 poemas organizados em três partes, conforme descrito na orelha por Guilherme Gontijo Flores:

[...] "Teorema", em que a secura da linguagem sobre o agreste do espaço flerta com o filosofema laminar e os usos de poder; "Missivas", com suas terras, léxicos, conflitos entremeados na lei do cão que em tudo impera, através de pontos marcados de sangue, como o Alto das Cabeças (morro onde se expunha a degola de criminosos sentenciados em Ouro Preto); e, por fim, "Letrados", com uma série de figuras que, por mais de metade do livro, instabilizam o espaço coletivo, entre humanos e animais, num movimento hesitante entre o topos literário (com Heitor domador de cavalos ou Proust), a sugestão de biográfico (nos poemas sobre Augustin Honorato ou Sebastião Polino), ou mesmo a zoopoética (morcego, boi, queixada...), sem nos resolver quanto disso é tão nosso, quanto pode e deve ser reclamado como nosso quinhão. ${ }^{209}$

Flores enfatiza ainda a precisão dos versos que ecoam no livro. Estes breves comentários podem nos fornecer o ponto de partida para a travessia de uma poesia seca, concisa e de concretude não menos complexa. A partir daí, almejo apresentar uma possibilidade de leitura mediante a variedade de contextos, pontos de vista, modos de

\footnotetext{
${ }^{209}$ FLORES, Guilherme Gontijo. Orelha para PEREIRA, 2017.
} 
vida e de expressão no entre da concreção de línguas diferentes faladas por gentes diferentes: um entre da escrita enfeitiçada pela oralidade. Nesse entre, é que a leitura aqui proposta tende a ver um estado de quasidade fantasmal xamanística. Ao catalisar transformações relacionadas a diretrizes corporais e verbais, a partir de uma abundância de forças de vida, penso que a experiência artístico-pensante de Edimilson compreende e faz compreender o movimento de mundos. Segundo este entendimento, as palavras do poeta apresentadas na epígrafe do livro parecem resumir a relação que se coloca: "Essa prosa não é da escrita. Mais se diz / na falha / da fala" ${ }^{210}$. O exemplo óbvio desta "falha" aproximativa é o próprio poema "Qvasi" que, sob perspectivas muito singulares, se diz assim:

por definição: língua geral

que serve

para toda obra, mas não

serve

de bom grado sua sintaxe

por sugestão: língua letal

que guarda em si

o gesto secreto: o não

língua que se traz no bolso

para ofício

de cortes

em tempos de fala-pires

língua-pinça

antiformigas

(tamanduá em ronda,

depois do incêndio)

língua para a celebração

do erre

uma califórnia de insetos

por condição: língua real

lesma sem ouro

no esterco língua

de nenhuma grei

${ }^{210}$ PEREIRA, Edimilson de Almeida. Qvasi: segundo caderno. São Paulo: Editora 34, 2017. p.9. 


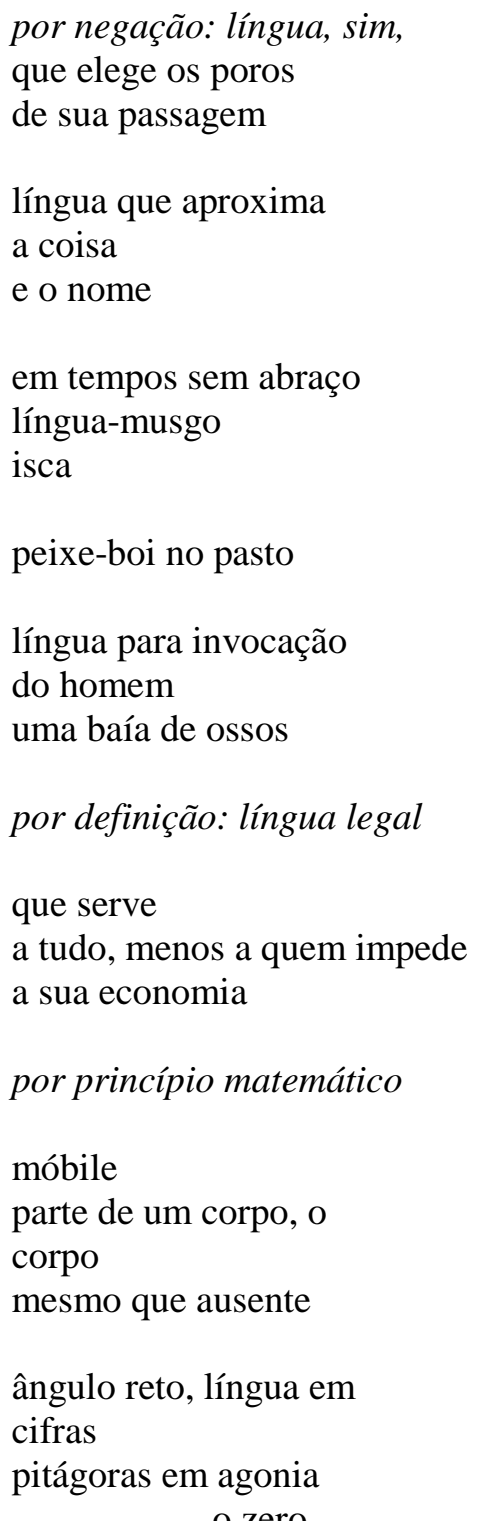

fração angular do pensamento, língua equação de seu próprio dilema por afirmação: língua

de escola, não apenas língua que em plena desordem

veste camurça - zelo de usuário 
que indo à casa de farinha

vai a paris

língua do faz-compra-na-

esquina

pega-tatu-pela-raiz

língua-bodoque, truque

para ferir

no brio

o bispo, o dígito ditador

por definição: língua

que mais serve sem

adjetivos

e as demais categorias

que nos fustigam

língua que tolera o homem

ínfimo

e sua falta

língua

porfírio clarismúndi: sibéria

de signos

tão avessa aos vestidos

desnuda

que a tudo reveste

língua: mendigo, mão exposta

à dádiva

— quem a recolhe a multiplica

serro

erro: sumário de paisagens ${ }^{211}$

De início, é impossível ignorar que Edimilson - poeta, ensaísta, professor de literatura, pesquisador da cultura e da religiosidade afro-brasileiras — em muitos sentidos é um outro dos outros: outro entre os artistas, o poeta é um afrodescendente nascido das classes populares, um outro também, é claro, para si mesmo.

${ }^{211}$ PEREIRA, 2017, p. 13-16. 
Venho de uma família periférica, a maior parte de meus estudos feitos em escolas públicas, e o contato com a leitura veio especialmente das aulas de língua portuguesa e da existência de alguns professores, sobretudo professoras. (...) Depois, veio a opção de estar do outro lado na sala de aula partilhando com os alunos essa experiência extraordinária que é o conhecimento do mundo e do homem por aquilo que se escreve a respeito do próprio mundo e do próprio homem. (...) Mais tarde, como pesquisador, ao identificar as áreas de investigação que me interessavam, meu foco passou a ser a questão das culturas populares. Conhecer o movimento do Congado dos Arturos, em Contagem, Minas Gerais, foi decisivo. A partir de então, o desafio passou a ser me transformar em alguém que investiga uma realidade cultural que me é conhecida em certos aspectos (o mundo popular de onde venho), mas que em outros aspectos me é completamente desconhecida (essa tradição e essa formulação). E a indagação fundamental era: como conseguir lidar com uma realidade que, ao mesmo tempo me era familiar, mas era completamente diferenciada? Ou seja, você é um outro dentro de um mundo que parece ser o seu. Daí vem aquela questão que até hoje define muito o meu trabalho: combinar efetivamente o campo (nesse sentido, a vivência com a práxis cultural para mim é fundamental) com o manancial teórico que o mundo acadêmico fornece. Como qualquer manancial teórico, é rico em contradições e se forma nas tensões. Ao mesmo tempo em que nos dá um certo mapa de interpretação do mundo, nos obriga a construir mapas de leitura desse mundo. É sempre nesse tensionamento, entre a vivência do cotidiano e a experiência acadêmica, que meu percurso de reflexão se construiu. $^{212}$

Assim, partindo primeiramente das palavras do poeta sobre seu percurso de reflexão e tentando depreender os princípios que regem sua concepção do fazer artístico-pensante, é impossível ignorar que o autor de "Qvasi” é um homem que vive no Brasil do século XXI entre fantasmas do passado e do presente. Sua concepção está entranhada por séculos de genocídio indígena e escravidão africana, racismo arraigado e preconceito linguístico tributário deste racismo, tendo como elemento fundamental a vivência com a práxis cultural, isto é, a própria implicação do corpo no trabalho de campo. Fica entendida a importância desse corpo ser lançado ao estado de véspera da diferença entre o conhecimento intelectual de seu próprio mundo e o saber do mundo sobre o qual ele está artisticamente pesquisando.

Em três décadas de uma obra extensa e múltipla com publicações nas áreas de poesia, literatura infanto-juvenil e ensaio, a produção artística de Edimilson apresentase marcada por uma mobilização em estabelecer algum contato com o que se promete outro por meio da enunciação literária ou da palavra poética.

\footnotetext{
212 PEREIRA, Edimilson de Almeida. Literafro Entrevista. TV UFMG. 2018. Disponível em:
} <https://www.youtube.com/watch?v=f9PXoq2G3Uo>. Acesso em: 4 jun. 2020. 
Assim, diante das palavras de Edimilson e do poema "Qvasi”, não hesito em afirmar que esse outro afrodescendente nascido das classes populares - esse outro dos outros entre nós - escolheu romper com qualquer postura neutra em virtude da força dos problemas que se impõem. Mais do que isso: para além do ambiente de especialização e dos próprios limites intelectuais, decidiu evidenciar que não há nenhuma estabilidade na prática poética. Trata-se de um contexto em que a perspectiva da instabilidade leva em conta também a ausência de parâmetros vigentes na poesia e na arte em geral, a exemplo do que destaca Paulo Henriques Britto. Ou seja, considerase a multiplicidade "de formas e posturas, temas e ritmos" 213 de que a poesia contemporânea dispõe "para elaborar um idioma próprio"214. Mas, vale ressaltar, tratase de um "próprio" que já é "outro". E não é por acaso que esse "próprio" não é visto, em tempos atuais, como sensibilidade emancipada. De qualquer modo, é preciso lembrar, ainda com Paulo Henriques Britto, que:

De modo geral, a nova geração já não vê o trabalho poético como uma espécie de emancipação de uma sensibilidade, uma visão que ainda estava em vigor nos anos setenta. Para eles, o poema não brota naturalmente quando se leva uma "vida de poeta" (ou "vida experimental", como dizia Roberto Piva), porém é fruto não só do talento como também da leitura, do estudo e do artesanato técnico. ${ }^{215}$

Destacando que a passagem em questão fala da arte como uma experiência que bebe, diretamente e a um só tempo, tanto da pesquisa teórica quanto do artesanato técnico, retomo aqui alguns rastros da enigmática relação de Kopenawa com a prática xamânica:

Os espíritos da yãkoana, chamados yãkoanari e ayukunari, ficam ao nosso lado. Ajudam-nos a pensar direito e nossas palavras não param de aumentar e esticar graças a eles. É a yãkoana que nos permite, guiados pelos xamãs mais experientes, ver os caminhos dos espíritos e os dos seres maléficos. Sem ela, seríamos ignorantes. Tornados

\footnotetext{
${ }^{213}$ BRITTO, P.H. A poesia no momento pós-vanguardista. In.: Literatura e criatividade. Rio de Janeiro: 7Letras, 2012. p. 116.

${ }^{214}$ Ibid.

${ }^{215}$ Ibid., p. 120.
} 
fantasmas durante o dia ou durante o tempo do sonho, é com ela que estudamos. Sem tomar yãkoana, como eu disse, não se sonha de verdade. ${ }^{216}$

É assim que vive o xamã. Kopenawa nos mostra que, se ele estuda, aprende e transmite sabedoria através das palavras verdadeiras dos espíritos da yãkoana, é porque se trata de um "pensar direito" que ganha o sentido de um "sonhar de verdade".

Considerando todas essas circunstâncias, vemos que Edimilson é um dos poetas que abrem espaço para questões que dizem respeito à relação entre alteridades. Além disso, não tendo ele interesse por uma perspectiva puramente racional e diante de tudo mencionado até aqui sobre seu fazer artístico, procuro pensá-lo no contexto mítico das matrizes africanas como uma espécie de torção da ideia de prática xamânica e que pode ser descrita como a experiência com uma entidade de candomblé que quer baixar, sendo o escritor, em alguma medida que não é simples, tomado como um cavalo de santo ${ }^{217}$. Penso que a evidência da entrega a algo que está se fazendo para além do próprio fazer é um dos traços mais ousados da relação do poeta com as coisas. Penso ainda que é importante celebrar a intensidade do trabalho de imaginação poética de Edimilson a nos permitir o acesso a mundos outros.

No entanto, por outro lado, parece-me óbvio que o próprio significado de “escritor como xamã" é passível de questionamentos no sentido de que, tanto escritores quanto xamãs não podem ser pensados como sujeitos fixos, prontos, produtos finais. Nesse sentido, ainda que se argumente que sua performance não seja tão radical quanto a de um xamã, sua produção insere-se no mesmo estado especialmente volátil de prática com as palavras em que o sujeito deixa de ser o centro e a origem de seu discurso, para ser entendido como construção polifônica cuja força se encontra em sua relação incontrolável com a vida.

O poema "Qvasi” indica mais algumas balizas que me convencem deste caminho. E o verso de abertura surge como primeiro ponto de ancoragem: "por definição: língua

\footnotetext{
${ }^{216}$ KOPENAWA; ALBERT, 2015, p. 137.

${ }^{217}$ Em entrevista a Steven F. White, Edimilson descreve, em parte, a relação de seu fazer poético com a mitologia Iorubá, no contexto do processo criativo de seu Livro de falas: "I felt the necessity to internalize, or to swallow the beauty of the myths and then to return them to the world. To take the myths within me was a way of knowing them, albeit partially. And what appealed to me the most was the idea of returning the myths with some extra meaning, beyond the sacred meanings they possess in Candomble”. (WHITE, 1996).
} 
geral”, em itálico, buscando, na relação com uma forma de vida (no caso, a língua geral), a transversalidade com saberes que não devem mais ser silenciados. Neste ponto, convém lembrar que, segundo Manuela Carneiro da Cunha, "os xamãs viram tudo" 218 . Neste "virar tudo", eles misturam saberes. Os xamãs recorrem ao método de viagens ao mundo dos bichos, da floresta, dos espíritos etc: ocasiões em que aprendem com esses seres sobre a realidade e na realidade de cada mundo. Ao retornarem dessas viagens, transmitem o saber apreendido à gente da tribo. Tais viagens, a partir das quais se busca conhecimento, constituem-se numa técnica xamânica de aprendizado e "substituem uma aprendizagem de tipo tradicional"219. Nesses casos, é preciso lembrar que "trata-se de uma metafísica que imputa um valor primordial à alteridade e, mais do que isso, que permite comutações de pontos de vista, entre eu e inimigo, entre humano e não-humano" ${ }^{220}$. Afinal, está em jogo a tentativa de demonstrar que quaisquer alteridades têm direito aos respectivos mundos.

Aqui, para ficar um pouco mais nítida a base dos saberes da negritude de que trata o poema, vejamos uma passagem do texto "A voz e a cruz de Rita: africanas e comunicação na ordem escravista", da historiadora Ivana Stolze Lima, que focaliza práticas dialógicas da chamada "língua geral de mina" no Brasil do século XVIII a partir de registros produzidos em Vila Rica, Minas Gerais, por Antônio da Costa Peixoto:

O conceito de língua geral, empregado por Peixoto, tem alguns equivalentes contemporâneos [daquela época], e é entendido aqui como língua amplamente falada com possibilidade de comunicação entre povos que se entendem como distintos. (...) A identificação da língua mina era percebida também por autoridades como Pedro de Almeida Portugal, o Conde de Assumar, atento ao potencial de resistência e comunicação dos africanos. Quando governador da capitania de Minas Gerais, em 1719, ele oficiou ao rei sobre a 'desordem que se experimenta em todo esse governo na mesma doutrina dos negros', elencando para isso dois motivos. O primeiro seria que os senhores não cuidariam de sua doutrinação. O segundo seria o mais essencial: ‘é porque vindo a

\footnotetext{
${ }^{218}$ CARNEIRO DA CUNHA, 1998, p. 12.

${ }^{219}$ Ibid.

${ }^{220}$ SZTUTMAN, 2008, p. 13.
} 
maior parte deles já adultos de Angola e da Costa da Mina, dificilmente aprendem a falar a língua portuguesa'. ${ }^{221}$

Lendo esta passagem, podemos perceber como a própria definição de língua geral está marcada por conflitos específicos da vida dos negros e, nesse sentido, falar a língua geral significava, para eles, resistir contra o sistema de saber letrado e político dominante. Por sua vez, a performance poética de língua geral praticada por Edimilson, buscando a liberdade do transitar, do falar, do viver, afirma-se como processo de incorporação de forças, ação sempre inacabada, ato crítico-político reimaginado.

Tal resposta performática àquele saber dominante é veiculada de modo a tornar a leitura opaca, uma opacidade às vezes intensa, operando como um convite ao leitor de permanência no desconhecido, por espaços refratários à pacificação ou à explicação. Por um lado, visitando o universo lógico-matemático, o jogo poético de "Qvasi” põe "pitágoras em agonia" - como se a poesia fosse um tipo de pensamento que perturbasse o caminho indicado pela tradição filosófica: do sensório para o matemático e deste para a dialética. Por outro lado, apresentando forte teor enciclopédico, mas sem o conceito tradicional de organização enciclopédica, o jogo poético faz a língua geral, com seu quase-corpo negro de língua de fantasma, avançar em estado selvagem pelos territórios em branco das páginas de um livro.

Ambas as perspectivas nos atraem e nos convencem a permanecermos diante do texto. No tecido desse movimento indiscernível entre um sujeito e aquilo que ele percebe, no jogo poético praticado por Edimilson, eu e outro são multiplicados em quase-sujeitos e quase-objetos cujos processos de subjetivações e objetivações revelam uma experiência de toque entre alteridades, jamais em regime dialético platônico, mas horizontalmente. Daí a "língua / de nenhuma grei" agir e reagir de acordo com um jogo potente a valer a descontinuidade das zonas de intensidade do poema em poros reimaginados: "por negação: língua, sim, / que elege os poros / de sua passagem / língua que aproxima / a coisa / e o nome”.

\footnotetext{
${ }^{221}$ LIMA, Ivana Stolze. A voz e a cruz de Rita: africanas e comunicação na ordem escravista. Revista Brasileira de História. v. 38, n. 79, 2018. p. 48-49.
} 
É diante dessa possibilidade de aproximação que a quasidade acontece. Aos olhos do filósofo Plotino (205-270 d.C), conforme pontua Alexandre Nodari ${ }^{222}$, a palavra hoion ("quase", em grego) deveria ser usada para se referir às categorias supremas (Deus, o ser). Nesse caso, seria possível entender com Giorgio Agamben, também convocado por Nodari, que a orientação técnica de Plotino serviria para fixar o termo hoion “como ‘operador (...) [da] indeterminação' entre potência e ato, indeterminação que faria ruir a ontologia clássica, dando lugar à ontologia cristã”223. Nodari segue comentando

(...) que é devido a tal separação que hoion possui tamanha importância para Plotino: como a matéria sensível é 'como que a expulsa [ekripheisa, lançado para fora] do ser, a totalmente exilada [choristheisa]', sendo pura potência indeterminada, suas atualizações não passam de 'imagens' e 'mentiras': daí que a linguagem, a fala, a escrita, enquanto partes do mundo sensível, são incapazes de exprimir com exatidão a matéria inteligível, o ser, Deus. A matéria é a exilada política do Ser, o quase não-ser, mas que sempre está e está sempre como outra coisa que si mesma. $\mathrm{O}$ banimento da matéria da esfera do ser é o equivalente ontológico do banimento platônico dos poetas d'A república. ${ }^{224}$

Isso nos leva à ideia de que o quase-acontecimento, proveniente da imaginação, também teria sido banido por Platão do processo de construção do conhecimento, na Sétima Carta. Nesse sentido, a experiência de imaginar com o corpo surge mais uma vez como potência. De algum modo, esse imaginar afirma-se como um procedimento de resistência aos critérios ocidentais (leia-se platônicos) de acesso ao conhecimento verdadeiro. De algum modo, o quase-acontecimento surge mais uma vez como o quaseser que se empina e se põe em suspensão, para "instaurar o caos que cria, que faz marchar os simulacros e levantar um fantasma - a mais inocente de todas as destruições, a do platonismo" 225 .

Procurando simplificar um pouco, embora não seja recomendável, a figura do fantasma, ao aglutinar os componentes corpo e alma em seu modo sui generis de existência, está ligada àquilo que é visto e àquilo que não é visto. Em "Qvasi”, como é

\footnotetext{
${ }^{222}$ NODARI, 2012.

${ }^{223}$ Ibid.

${ }^{224}$ Ibid.

${ }^{225}$ DELEUZE, 2009, p. 271.
} 
negada ao leitor qualquer possibilidade de transparência das imagens verbais, a complexidade imagética do poema, a partir de uma língua de fantasma, língua "de um corpo, o / corpo / mesmo que ausente", não pode ser explicada em seu sentido (digamos) metafórico generalizante, este que opera a partir da reunião de elementos de campos semânticos distintos: o como se.

Neste caso, tal discussão diz respeito de modo imediato ao seguinte questionamento: será que a experiência poética cria semelhanças ou mostra semelhanças e diferenças já existentes? Em obras poéticas vigorosas, como no "Qvasi”, mais do que mostrar semelhanças ou diferenças, o sentido está sempre às vésperas de completar, mas nunca se perfaz plenamente. Além disso, de forma transformadora, abrem-se talvez espaços para uma "fração angular do pensamento". Não uma aberração geométrica, mas um certo grau de abertura por onde se insinua essa língua de fantasma Vejo nesse simulacro-fantasma uma afirmação da dessemelhança pela quasidade quasidade fantasmal —, onde a negação é a véspera do sim; a língua geral é a véspera da língua letal; assim como a língua que desnuda é a véspera da língua que a tudo reveste; que veste camurça indo à casa de farinha, véspera de paris. Na busca por uma "língua / que mais serve sem / adjetivos / e as demais categorias / que nos fustigam", experimenta-se a quasidade fantasmal que se volta para as ações desses estados intermediários de uma "língua que tolera o homem / ínfimo / e sua falta": "— quem a recolhe a multiplica".

Quem a multiplica experimenta uma estratégia artística levada a cabo pela "falha" exposta entre gentes diferentes, entre códigos de comportamento punitivos e forças reinterpretativas de práticas políticas de resistência a tais códigos. Falha esta que não se encaixa muito bem naquela máquina binária da razão classificatória do mundo, escapando assim à alternativa dicotômica simples. Por isso, defendo que podemos desse modo partir do princípio de que se trata de uma espécie de falha aproximativa: algo como uma estranha interação entre oralidade e escrita muito mais complexa e que se oferece ao leitor a partir do encontro xamânico de forças do poema em um processo de tensão constante entre mundo, vida e imaginação. Desse processo, ainda ficamos com algum substrato importante para considerar a ideia de que escrita e oralidade parecem manter laços constitutivos, contudo, diferenciando-se. Tem-se, assim, a 
possibilidade de se relacionarem, humanos e não humanos, como se relacionam, em “Qvasi”, vidas negras, vidas musgas, vidas lesmas, modos de vida e de expressão, falares e saberes. Conectam-se e lançam-se uns sobre os outros de modo a incorporarem mais forças. Forças de relações que se querem mais inimagináveis e que atuam não apenas no pensamento do poeta, mas se oferecem como efeito descalcificador — este que se pode atribuir aos movimentos de mundos a enfeitiçarem o corpo da escrita.

Por outro lado, tal efeito, trazido desse trânsito entre mundos, sugere a força do já mencionado quase-corpo de fantasma "que serve / para toda obra" e que, mesmo não servindo "de bom grado sua sintaxe"; mesmo sendo vítima de violência por parte de outro modo de construção de linguagem e de mundo, deixa de ser servil para se tornar uma atividade a que se poderia chamar "letal", guardando consigo um "gesto secreto": um "não”. Segundo comenta Sílvia Margarete Cunha Souza, "os enunciados assertivos negativos da língua geral de mina são caracterizados pela presença de morfemas de negação correlacionados com distribuição fixa na frase" ${ }^{\text {226 }}$. Um desses morfemas aparece sempre no final do enunciado afirmando algo como "eu/não/sei/não"227: algo que recusa um rendimento, uma função.

Este ato performático nos transporta para o mundo de uma "fala-pires" na boca de gente que, por não ter quase nada, tinha tudo para viver de pires na mão. Mas em "Qvasi” essa "fala-pires” prefere deslocar-se para se fazer voz poética. Em estado de véspera de uma "língua-pinça / antiformigas", é língua-faminta, sim, mas tão esfomeada quanto vigorosa e cuja força aspiradora e inspiradora se manifesta no corpo de um "(tamanduá em ronda, / depois do incêndio)".

Essa experiência de imaginar com o corpo coletivo de um povo escravizado - e empurrado à condição de fantasma em uma sociedade — obriga-nos a ler o texto como um vulto que aparece no entre da escrita com a oralidade para tornar visíveis o racismo e o preconceito linguístico vigentes. Reiteradamente, a cada estrofe cuja estrutura produz um efeito de semelhança ao longo do poema - estrofes estas que ganham pausa ao final de cada sentença —, o quase-corpo desse vulto funciona como índice de disseminação cultural constante. Em suas pausas marcadas, um dos efeitos dessa

\footnotetext{
226 SOUZA, Silvia Margarete Cunha. A predicação da língua geral de mina. In.: PAPIA-Revista Brasileira de Estudos do Contato Linguístico. v. 13, n. 1, 2010. p. 100.

${ }^{227}$ Ibid., p. 101.
} 
aparição é o de trazer ao leitor situações distintas de confronto entre modos de dizer e de viver. Tais situações extrapolam a imaginação de uma língua como abstração, como algo que acontece apenas no pensamento. Note-se que a "língua do faz-compra-na- / esquina / pega-tatu-pela-raiz" e é tornada "língua-bodoque" que, por sua vez, conhece a besta de um bispo ditador e a oportunidade incisiva de feri-lo, seu dedo em riste. A cena, descrita apenas nas estrofes finais, é um exemplo dessas situações de confronto, ressaltando-se, por outro lado, em versos anteriores, possibilidades de diálogo: note-se que, "em tempos sem abraço", uma "língua-musgo" se veste de "isca" para "peixe-boi no pasto". Um pasto aquoso por onde navega a "língua para invocação / do homem / uma baía de ossos".

Em "Qvasi”, como as cadeias dialógicas são infinitas, escolho neste ponto voltar mais uma vez os olhos à disposição gráfica propriamente, por onde avançam pela página versos um pouco mais alongados — "língua para a celebração" — (qual?), para então recuarem diante de um "erre" cortante, capaz de torcer o "l" como quando se diz 'eu vou logo ali e vorto já'. Noutras palavras, ali a língua geral desobedece a ordem, impondo-se na (des)ordem do discurso. Essa língua torcida torna-se capaz de nos trazer a sensação de entrada numa caverna profunda e repleta do ruído ensurdecedor de um enxame de insetos em animada conversa: "califórnia". Essa língua torcida que escapa à nossa categorização simplista de racionalidade torna-se capaz ainda de afrontar a "língua / porfírio: clarismúndi: sibéria / de signos", véspera de um "sumário de paisagens". De qualquer modo, na concretude do poema e suas relações e na variedade de cortes empregados por Edimilson, ao caminharmos pelas páginas, indo e voltando nos versos de "Qvasi", observamos mais este exemplo da nossa cegueira antropocêntrica, nossa gélida indiferença, nossa incapacidade de escuta do outro humano e não humano. Este outro que ali se deixa ver/ouvir parcialmente como acontece na experiência xamânica de viagem ao mundo dos espíritos, dos bichos, das plantas...

O quase-corpo desse outro não só dita as palavras como impõe o ritmo com um sotaque cuja intensidade nos atinge de modo singular. Quanto ao ritmo propriamente, "Qvasi” segue o tom fluido de cadência encantatória, com algumas quebras súbitas, 
visíveis enjambement ${ }^{228}$, quando as separações entre as frases acontecem fora da posição final do verso. Essa desarmonia rítmica relaciona-se ao transbordamento do sentido de um verso noutro verso: transbordamento este ora suave, ora abrupto e acelerado. Neste experimento perspectivista de leitura, sublinho mais uma impressão: a de que o feixe de relações entre os diferentes recursos poéticos utilizados por Edimilson remete àquilo que Kopenawa destaca como sendo um dos elementos constituintes da prática xamânica Yanomami: a "dança de apresentação" dos chamados xapiri os quais chamamos de espíritos que são quase-corpos que são imagens de quaseanimais da floresta que são afinal... Se Kopenawa reconhece a dança dos xapiri até mesmo quando os movimentos e ritmos mudam, é porque os xapiri são um sopro de vida. Nos movimentos e ritmos da vida, cada xamã e cada artista, quando imaginam com o corpo, estão sujeitos às delimitações de percurso em cada viagem entre mundos, em um limiar nem sempre consciente, às vezes intuitivo. Porém, isso pouco importa. Assim como pouco interessa a construção prévia de alguma coisa, importando mais os ritmos e velocidades que se desfazem o tempo todo, em um contínuo de descontinuidade, em um sentido que transborda a significação.

Assim como muitas vezes é labiríntico o lugar em que se dá o cruzamento de fronteiras no ato de leitura. De algum modo, nessa viagem a outros mundos, mesmo que se tente descartar a intuição, uma certa desordem se impõe e um certo desconforto permanece. Em meio a este desconforto, preciso assumir que, desde minha primeira tentativa de enfoque sobre o texto, a dinâmica de procedimentos da voz poética ganhou existência antes que eu pudesse ler as palavras do poema, as palavras em si. Enquanto testava meus próprios limites como crítica leitora, sentia, durante o processo de construção desta escrita, que a leitura das palavras muitas vezes tinha importância secundária e ganhava importância a sensação de estranhamento diante do ressoar dos tambores quando se tem no corpo a memória do contato com uma dança de apresentação de grupos de Congado em cidades do interior de Minas Gerais.

Me lembro de algumas manhãs de domingo, logo depois de ter me sentado no balanço preso por cordas aos galhos da jabuticabeira. Sou atirada na imensa extensão do quintal. Sou empurrada para frente e para trás por minha avó. Me lembro

\footnotetext{
${ }^{228}$ MOISÉS, Massaud. Dicionário de Termos Literários. São Paulo: Cultrix, 2004. p. 143-145.
} 
principalmente do quanto me sentia livre da gravidade. A audição dos tambores, das canções incompreensíveis e a agitação dos pombos vindos da praça em frente de casa tocam as páginas do livro abertas no "Qvasi”. Em contato com a textura do papel e com a irregularidade das linhas impressas, meu corpo suspenso em um líquido de palavras é transportado de volta ao balanço. Por um momento, solto minhas mãos das cordas e meu corpo suspende-se do assento. É um instante em que minha mente oscila e todos os outros elementos ali parecem oscilar com ela. A partir de então, nenhuma linearidade, nenhum encadeamento entre presente, passado, futuro, nenhuma história com início, meio e fim.

Foi como se fosse um sonho, como nos acontece o tempo todo, até mesmo quando estamos acordados. O fato é que tal estranhamento me trouxe até aqui na seguinte situação: neste pensar em voz alta que é o ato público de leitura no contexto de uma tese, ao ler o poema "Qvasi”, por algum motivo parece que estou vivendo no mundo da minha infância na terra natal. Entretanto, embora o poema se apresente para mim como o acontecimento de uma viagem para a qual me é indispensável certa bagagem e, embora por instantes as palavras do poema se façam presentes aqui como o ressoar dos tambores do meu mundo na infância, neste ponto chego a um limiar onde ganham sentido as palavras do poeta ao dizer do próprio percurso de reflexão: "você é um outro dentro de um mundo que parece ser o seu"229.

Assim, seguindo uma intuição vinda de um lugar que parece ser o meu, gostaria de testar mais uma possibilidade de leitura, retestar os limites de estranhamento daquilo que é quase nada ignorando a gravidade da razão e da lógica. Tentando sair do conforto que me resta, penso que, mais uma vez considerando o que há de absurdo e irracional no modo de imaginar com o corpo, gostaria de assumir o fato de não haver controle total sobre o que se passa. Para isso, na próxima seção, gostaria de partir para um exercício de imaginação acompanhado de uma reflexão em torno de mais um fazer artístico em conexão com certas forças babélicas da vida.

${ }^{229}$ PEREIRA, 2018. 
4.4.

...nós, as pedras: "O sofredor do ver”, de Maura Lopes Cançado

Ler, escrever e viver: imaginar pode ser uma experiência profundamente desestabilizadora ao ponto de exceder qualquer compreensão para desembocar no mesmoutro do pensamento. Impensável isso de estar de volta sentada na escrivaninha do quarto falando com o computador e pondo em legendas sonoras as imagens que a manifestação de um personagem pode provocar. Mal consigo prender o riso quando enxergo um sujeito cantarolando uma canção e tocando um instrumento. Comendo uma massa fumegante e seu molho fresco e tomando um vinho tinto, está lambuzado como uma criança. Ao sabor de enrolar a massa e deixá-la rolar na boca, desenha a borda do prato com o garfo e o molho, desenha tão perfeitamente que isso podia mesmo ter acontecido. É permitido sentir fome de macarrão àquela hora. Não tem nada para fazer além de passear e é segunda de manhã. Mas se afasta. Como se fosse proibido comer. Como quem será repreendido feito criança diante de uma panela de brigadeiro de colher.

Noutra dessas imagens, certa coluna delgada faz pensar numa marionete em sua flutuação agitada, seus movimentos repetitivos. Aquele rosto pálido aponta para as pessoas e fala num megafone como se estivesse num picadeiro. Como se usasse perna de pau, é de uma palidez assustadora. Entoa um pregão rítmico com entusiasmo. Respeitável público, diz o sujeito. De que planeta veio essa figura? Fala umas coisas e tem uma voz grossa que lembra a de um urso. De modo arrastado, rosna seu ursês que vem do fundo da garganta contra a língua e os dentes sem propriamente abrir a boca. Parece um boneco e, além de tudo, tanta criatividade no modo de vestir não podia imaginar. Numa certa altura, ele ri, ri muito, uma risada que soa falsa, talvez cínica? Tem simplesmente um jeito próprio de fazer as coisas e o fato de estar sempre sorrindo para o lado de cá faz pensar que há um desamparo na felicidade de qualquer sonhador do inimaginável. Embora não se tenha nunca a menor ideia de todos os outros mundos sonhados por aí, é possível que ele saiba que estou prestando atenção. Há chances reais, sim, de qualquer modo, contra a probabilidade irrisória de não ter sequer notado o quanto pretendo passar a noite toda aqui, me divertindo como nunca, como jamais se viu, possuída que estou por essa espécie de soneca. 
Mas por que é que teria paciência para imagens tão precisas quanto inexplicáveis como as palavras dos livros que se lê e quase sempre se esquece? Queria conversar com quem estivesse disposto a entrar numa conversa. Se estou conversando não posso estar dormindo. Estou escrevendo antes de começar a escrever. Então dialogava com potenciais personagens e essas imagens me respondiam embora depois não me lembrasse de nada do que disseram e muito menos do que propriamente disse. Não tentava acompanhar o que diziam e isso era como uma marca minha, estava acostumada a não trocar ideias cara a cara, não trocava nada além de um bom-dia e de um boa-noite com o porteiro sempre gentil, não me aproximava de alguém fora do meu universo havia muito tempo.

Dessa vez penso em abrir uma pasta, criar um arquivo, dedilhar as teclas, dar enter e pôr na tela em caracteres sem rabiscos ou rasuras fiapos de histórias, oferecendo-lhes a possibilidade de dar a elas o nome daquilo que não tenha imaginado ainda. Com tal constatação preliminar, talvez por isso mesmo tenha intuído que de modo algum a escrita sonhada para uma história que se pretende contar nasce tão somente de um passar os olhos em outras escritas. Sua construção é certamente tributária desse enfrentamento introspectivo, mas também de imponderáveis escutas dos rumores selvagens da vida. Seus urros e uivos rebeldes. Por falar nisso, pode ser divertido ficar imaginando ainda para onde voam os pernilongos, invisíveis em dias de frio.

Mas sou forçada a recuar no mesmo instante. Preciso sair dali, não posso piscar. Porque tenho de estar aqui onde se evidencia como o mais sensato pensar que tudo o que terá de ser feito está na nuvem difusa da tela, densa e branca. Pois dessa densidade viria o caminho e, sem dizer logo a que veio, ao alcance da mão, o corpo de uma palavra: PEDRA. O porquê desse corpo ter se intrometido aqui, não sei. Esse tipo de... o que é isso? Parece quase imóvel, a palavra PEDRA sendo: tornada ato substantivo e abrindo o texto. Lá, naquele conto "O sofredor do ver", que tinha o costume de ficar 
na cama lendo, passava horas com ele. Horas buscando alguma experiência de existências fora dos limites humanos e tentando me agarrar a certa autonomia que seria sempre limitada, a da história de um ver a partir da relação humana com algo ainda não classificado em nenhum reino, embora objetivo e direto, indubitável como o mineral, diz a escrita de Maura Lopes Cançado.

Depois de meses longe do conto, tento voltar com ele à cabeça. E ao corpo. Quando escrevemos, andamos atrás de uma trama ou outra, algo de que possamos nos socorrer para escrever outras vidas. Por sorte, algumas escritas nos atingem completamente. Pois hoje, relendo "O sofredor do ver", vem a pergunta: Saberia corresponder àquele olhar na página? "O texto-coisa me espia. Com o olho de outrem. ${ }^{230}$ Um olho feito de outros olhos. Um texto feito de outros textos. Ali onde leitor e escrita, entre outras coisas, tendem a se contaminar. Saberia corresponder? Consigo lembrar dessa pergunta feita na primeira vez que li o conto e querer retomá-la talvez seja exagero, mas sei exatamente como foi quando puxei os primeiros fios dessa leitura e vi que a palavra pedra ecoa, sobretudo entre geólogos, como uma demonstração de ignorância. Essa lembrança faz retornar uma pesquisa minimamente leviana feita à época. O resultado da pesquisa dava conta de que, mesmo que se conheça as palavras pedra, rocha e mineral, qualquer um que não seja geocientista não costuma fazer distinção entre calcário, quartzo, areia, turmalina...

E lembro que, quando criança, ficava muito brava quando me sentia enganada. Mas não me deixo intimidar. Que pedra mesmo era aquela, a do conto? Ficou na memória, sempre vai estar lá e nunca vou esquecer de ter lido na cena de chegada do texto, em suas diferentes imagens, entre verbal e visual, que um homem, disperso nos muitos elementos que o compunham, ia e voltava ignorando de onde: perdido ganhando em busca, atravessava uma praia que poderia muito bem ser um deserto amarelado por um sol triste, um desses espaços amplos onde não se respira o ar de casa. Terreno despido e de ninguém. Mais que meio sol sumido atrás das montanhas, um homem atravessa um lugar triste e sombrio como quem se deixa vestir por uma roupa de palhaço quando se busca no show algum pertencimento.

${ }^{230}$ MENDES, Murilo. Poesia completa e prosa. Rio de Janeiro: Nova Aguilar, 1994. p. 740. 
Já enredada nessa leitura, lembro principalmente de ter pensado que, embora fosse impossível reconhecer algum rosto nesse homem ou notar se ele carregava nas mãos sequer um objeto que o identificasse, não faltava humanidade suficiente a mim mesma para aderir àquele caminhante sem nome. Levanto a cabeça e me vejo caminhando com ele. Por um momento, existe uma sensação movediça de areia viva sob os pés. A brisa que vem do mar fica mais forte, assobia. Do mesmo jeito com que um ar estranho toca meu rosto e me impele de volta à leitura. Impelida novamente para a pele do livro, aperto o passo e, ao chegar mais perto, continuo vendo o homem penetrar anônimo uma paisagem inóspita, indo e voltando sem saber de onde veio e não sabendo mesmo aonde já chegara. Mas como se sabe que ninguém chega de repente a um deserto, do mesmo modo que as palavras arrastam mundos e ações, leio que o lugar que o homem ocupava naquela história do ver não era privilegiado. História difícil de reconhecer por se tratar de um ver que percorre trajetórias para além do humano.

É óbvio que aconteceu algo a partir do dia em que fui apresentada àquela história embora não dê para pensar que esteja ficando louca. Pelo menos não do modo como a autora do conto se sentiu um dia a ponto de procurar instituições e por conta própria se internar. Não dá para pensar isso, mas a palavra "louca" me vem mais uma vez no pensamento, assim como a palavra "normal", e toda uma história e todo um mundo que se fazem arrastar por essas palavras. Se elas arrastam vidas, o que era aquilo então? Escrito durante uma das internações da autora em hospitais psiquiátricos, o texto foi publicado pela primeira vez no Suplemento Literário do Jornal do Brasil, em 1959. À época, em conversa com a colega de jornal, Maria Alice Barroso, a autora ouviu a seguinte declaração sobre o conto: "Maravilhoso. Como você mergulhou fundo desta vez"231.

No que se refere ao modo como empregamos as palavras, sabemos que "mergulhar fundo" é um modo de dizer do nosso senso comum. Um modo com o qual buscamos expressar a intensidade de uma experiência. Seja com propósito científico ou artístico, um pesquisador que se aventura na experiência do conhecimento procura "mergulhar fundo" em relação ao estudo de determinado fenômeno. Pois bem, Maura

${ }^{231}$ CANÇADO, Maura Lopes. Hospício é Deus, 2015. E-book. 
Lopes Cançado era uma escritora que repetidamente ia fundo. O que buscava era fazer arte. No caso de Maura, entretanto, do ponto de vista artístico-investigativo, ir fundo nessa busca não tinha nada a ver com procurar atingir níveis de profundidade simbólica. De outro modo, tinha a ver com pôr em relação palavras e ideias, corpos e espíritos, modos de existência e de conhecimento, na escrita. Ou em "peles de imagens", diria um xamã Yanomami.

Mas esta é uma outra história. Outra história de outros mundos onde se pode talvez vislumbrar um dos mais ricos caminhos para a travessia da leitura de "O sofredor do ver". É que do lado de cá, no nosso modo de dizer, enquanto imagens de superfícies, peles podem ser entendidas como figurações de um mundo-corpo. E é por essa direção que se encontra ressonância da imagem de uma pele noutra pele para dizer que Maura expôs o corpo da escrita e o próprio corpo à multiplicidade de forças de um imaginar em sua dimensão concreta, vivida e inscrita no dentro-fora de sua carreira de escritora. Deixando-nos levar por sua recusa ao nosso sentido tradicional de profundidade, é possível verificar inúmeras idas ao fundo da superfície, na série de escritos seus em torno da experiência manicomial cujos temas vão da religião à loucura, passando por Deus, por ela mesma, pela relação entre pessoas, entre pessoas e coisas, e pelo olhar.

$\mathrm{Na}$ escuridão. Aliás, o que teria sido a escuridão mais densa que fluiu interminavelmente ao longo da vida de Maura? Seria a escuridão da crueldade de um hospital psiquiátrico? Aqui não foi isso que aconteceu. Após a leitura, apenas vi no espelho que meus olhos estavam gordos brilhantes e vermelhos como ocorre quando aprendemos alguma coisa surpreendente. O antes e o agora, o nós e o eles, o ela e o eu se enovelam e se enroscam trazendo de longe as palavras do conto. Saem de lá e vaise trabalhando com as palavras aqui.

Aqui, um texto e outro se encontram e mais uma pergunta flutua: onde estava com a cabeça que não tinha sublinhado ainda não haver ali uma narrativa de ação propriamente dita, mas uma trama questionadora que apresenta proposições sobre o olhar? Trama não menos poderosa, pela própria recusa em desenvolver um enredo, mesmo estando escrito que havia ali uma história a ser contada, mesmo que começada há pouco sua história tinha um título: A história do ver. Tal história do ver surge como um efeito delirante dessa narrativa sem narratividade. Delirar ali portanto não significa 
apenas construir imagens verbais na contramão de uma expectativa mimética de representação, mas também problematizar toda a relação do sujeito do conhecimento com o objeto a partir do olhar, estando em jogo um ver que se faz presente enquanto variação contínua na qual a materialidade das relações entre corpos é intensamente marcada. O que há de homem na pedra e o que há de pedra no homem se convertem em material para o texto de Maura.

Onde estava com a cabeça que não tinha sublinhado ainda... Talvez, como o homem de "O sofredor do ver", desligara-me para caminhos apenas, permitindo-me ir e voltar ignorando de onde. Indo e voltando, o homem chega a uma pureza rútila inclassificável. De brilho tão intenso quanto selvagem, de uma intensidade capaz de cegar. Num instante, vira a cabeça para o lado e cruza seu olhar com o olhar de uma pedra. Tento imaginar se aquele olhar profundo, seco e sombrio tinha alguma referência para o homem. Imagino como devia estar se sentido já que era sobretudo forma. Sobretudo sólida. Sólida e nua como para sempre. E pedra. E só, surgindo da areia. Entretanto, é interessante observar que o apelo à visualidade não é radical. De início, nos confrontamos com a visão de uma PEDRA. Inteira em maiúscula. E o conto inicia com frases condensadas. Períodos incompletos. Palavras tomadas como corpos nos obrigam a ler como se olhássemos para objetos.

A partir daí, seja em desvios sintáticos ou gramaticais, a experimentação linguística também é discreta. Maura tangencia. Sublinho aqui uma passagem que marca esse tangenciamento: E com esforço, da forma aos olhos, isolou o elemento de ligação. Vago no princípio. Crescendo em entendimento viu sem lentes na claridade do meio-dia. A visão, clara e feliz em traço reto. São deslocamentos sutis esses que podem ser percebidos na sintaxe. $\mathrm{Na}$ passagem citada, é interessante observar o isolamento do olhar enquanto elemento de ligação entre homem e pedra e a supressão do próprio verbo de ligação na frase. Assim, a visão não é clara e feliz, mas a visão, clara e feliz promove uma aproximação que afasta; um afastamento que aproxima. Experimento discreto no que diz respeito ao deslocamento de formas linguísticas e ao apelo à visualidade, sublinho aqui tais aspectos apenas por considerá-los um aperitivo para a leitura. 
Porque o olhar permanecia lá. Terrível. Inconfundível. Preenchido de homem e de pedra. Ela, a captar a presença do homem. Se ela olhava, ele passava a existir. Não conversou com ele. Porém, chegando úmida e jovem, a pedra prosseguia sem parar de olhar, na frase seguinte, e na seguinte, e na seguinte, e a visão saindo fina, além de quieta, a pedra.

Não conversou com ele, mas dela vem algo mais do que silêncio e, dessa interação de olhares, salta das entrelinhas uma seriedade e instala-se um quase sofrimento, entre o propositivo e o poético, no coração da terra que é o coração de lugar nenhum. Um coração que pode muito bem se transformar em indiferença ou numa árvore a quem o homem está prestes a contar um segredo. Oi, por favor, alguém pode me ouvir? Por favor, responde alguém! Talvez por isso ele tenha sentido tanto o impacto do olhar daquela pedra. Acontece então de o espanto ceder espaço a uma cena em que vejo um homem que se ocupava do que julgava mínimo e despercebido aos outros.

Ocupando-se do que julgava despercebido aos outros, a escritora Maura, por sua vez, produziu pouco ao longo da vida, teve uma produção contida mas bastante densa. Além de ter sido contida a produção, foi muito rapidamente que circulou no meio artístico, num círculo pequeno, e não esteve envolvida com nenhum movimento altamente inventivo. Ainda assim, é visível em sua obra a retomada de traços do movimento vanguardista do início do século XX (este que levou a crise da representação à sua radicalidade), tendo em vista a amplificação e o desdobramento de questões levantadas por essas vanguardas. Entre as quais, o formato interpretável de uma pedra na pele de uma escrita e algumas características capazes de aproximar tal escrita de fazeres surrealistas, como o cinema de Buñel com seu olho rasgado por uma navalha em "Um cão andaluz", de onde escorrem tentativas de subversão dos nossos modos de imaginar, além de um convite para uma viagem a mundos que não estamos acostumados a ver. E não podemos esquecer que, na prática da criação surrealista, artistas "videntes e intérpretes de sinais (...) fazem explodir as poderosas forças 'atmosféricas' ocultas nas coisas" ${ }^{\text {232 }}$.

${ }^{232}$ BENJAMIN, 2012, p. 25-26. 
“O sofredor do ver" é um experimento artístico que não se tornou antológico, o que o torna ainda mais instigante. Nele, o homem que se ocupava do que julgava mínimo, com uma expressão abobalhada, nunca imaginou ser possível descobrir um mundo ao se perder. Passando a se ocupar de um sofredor - um sofredor e sua história não só do ver, mas também do sentir - , o homem nunca tinha imaginado um mundo novo e sutil que se capta em luz e velocidade como aquele: da pedra e do olhar. Como acontece entre vidas que têm algo em comum, ele que sempre pensou nas dificuldades subterrâneas dos ratos e sempre evitou matar o mais pequeno inseto; ele para quem mundo era mundo e que sentia-se rico e despojado ao mesmo tempo...; ele ignorava o imprescindível de sua pessoa no mundo, apenas sendo, como a pedra.

Porque o olhar permanecia lá. Personagem e tema, permanece como imagem invisível capaz de captar a realidade atormentada que se instala entre a forma de vida humana e a não humana. Ao perceber tal tormenta, ele (o olhar) suscita uma tensão diante das possibilidades de aproximação entre homem e pedra. É sobretudo um olhar reinventado que imagina com o corpo. Olhar ingênuo e desprotegido. Não ingênuo como o de um bichinho de estimação. Poderia ser evidentemente bonito e convidativo e o homem teria apenas vontade de ajudá-lo não fossem os gritos sufocantes desse olhar. Tão desprotegido quanto humano, de um olhar como esse, recomenda-se manter grande distância: siga para o sul, ou para o norte, siga para longe, grita o olhar. Por isso mesmo, ao se ver no caminho de tal pedra como quem se vê na direção de uma manada, o homem certamente desejou andar veloz em sentido perpendicular ao dela. No entanto, nos ouvidos pendurados em sua cabecinha protegida, gritavam-lhe de dentro, ensurdecendo-o como se o chamassem para si próprio. Afinal, quem foi mesmo que disse uma vez que nós humanos sonhamos agarrados à cadeira elétrica? Sempre essa coisa da velha cautela humana. Velha e sem graça.

A estratégia encontrada pela autora foi a do enfrentamento com os nossos modos de imaginar do pescoço para cima, presos à cadeira elétrica. Dessa maneira, a história contada por Maura traz o cruzamento de uma fronteira entre um mundo de visão e um outro mundo. Em conflito com os desejos e as imposições de um olhar que se julga superior, o homem cerrou as pálpebras nauseado, toda aquela exigência gritando-lhe enérgica, tentando em desespero íntimo fazê-lo voltar-se para seu próprio corpo. De 
olhos fechados, nunca tinha compreendido o mar daquele modo e ficou maravilhado. Estendeu as mãos para o calor agradável e, em paralelo, a pedra. Não totalmente em contato, sem comprometer-se, o homem perdeu-se um pouco mais como quem se larga em tempo sentando-se num banco e deixando os dedos soltos e alegres. Do outro lado, as sombras não eram propriamente vistas nem tocadas. O homem esticou as pernas e inclinou-se, a fim de sentir as sombras em seu rosto. Ocultas em frente como algo cobrindo a si mesmo; compactas, eram justamente a falta. Sentia-se pesado. Talvez a gravidade daquela falta de contato. Ou o cansaço da luta entre as sombras compactas que tentavam avançar por áreas resistindo cruas, pátios cimentados por uma miopia humana. Olhou e através do escuro da morte que disse ter visto, o mar não era mais nítido, apenas a cintilação de uma corrente dourada pelo sol. Resolvendo deixá-lo então virou-se mais uma vez vendo a pedra. Não sabia o nome dela.

Devia haver mais olhar, e havia. Caminhando com o homem, o olhar reaparece largo como água que se entorna e espalha respeitando os limites encimados de azul, projetando-se árido na certeza mineral sem pulsações. Gostaria de beber alguma coisa. Sim, água. Enquanto um olhar sedento, principalmente míope, ultrapassaria suas próprias possibilidades se penetrasse massa opaca. E até beberia toda a água. E o homem ficou de fora, sentado, hesitante, admirando o olhar entornado, cego às porosidades da pedra porque pedra, finamente desenhada, refletindo o brilho do sol em sua borda. Estava até então ignorante e por isso talvez tenha trancado as pálpebras, abrindo-as buscou rápido o momento da partida. Não o alcançou, sofrendo a pedra imediatamente.

Estava atento às próprias atitudes e a alguma coisa que precisava ainda ser quebrada no mais fundo de si. Uma proteção, um respeito. Ou um sentimento de propriedade para com a pedra. Ergueu os olhos para ela. Rosto no rosto. Ela o olhou, em expectativa. O que fazer com ele? Bem, aqui estou, ele não disse mas poderia ter dito, enredado que estava no ver daquela história. Enredado numa maneira de ver e de ser visto que ia desmanchando o seu lugar hierárquico nessa forma de vida que o prendia a um condicionamento do qual necessitava se libertar. Nesse modo de viver, por séculos à procura do que lhe desse vida, em ondas visuais se integrando, repetindo- 
se, nessa natureza está o fundo do mar, estão as estrelas. Há um homem contornando a pedra.

O que Maura fez foi narrar uma migração de sensibilidades a partir da condição insular de homem e de pedra: a sensação do homem ao olhar a pedra e ser olhado por ela, a sensação do próprio conhecimento encarnado. Disperso nos muitos elementos que o compunham ou ingênuo e desprotegido como o que se toma no colo, trata-se de um ver (um conhecer) atravessado de alheamento, insegurança e náusea: Pensou um pouco compreendendo humano, cerrou as pálpebras nauseado, toda aquela exigência gritando-lhe enérgica, tentando em desespero íntimo fazê-lo voltar-se para seu próprio corpo. Até onde essa migração de sensibilidades pode levar o pensamento?

Não dá para pensar que estou ficando louca. Apenas sonhei coisas muito estranhas, um sonho grande, comprido, impossível de acabar por mais que tentasse e é assim que estou sentindo, eu mesma, estou me sentindo cega por estar ocupada com a luz ao trabalhar com as palavras que ouvi o homem contar. Sei que vou ter de passar por isso de algum modo vendo os efeitos de seguir adiante no que está diferente. Esses efeitos são os de uma maré que vem subindo. Como está quase acabando, mas nunca termina, como não acho o interruptor e jamais apago de uma vez por todas, devia mesmo era seguir uma rotina de exercícios físicos. O bom-senso, não, não ele, mas o desespero de que o exercício possa me redimir enfim com algum bem-estar. E é isso que está difícil. Pedalar, caminhar ao ar livre, correr na esteira por uma hora, fazer pilates, yoga. Se puder meditar então.

Ainda meio zonza, sentei-me agorinha e o antebraço direito mostra desta vez três longas cicatrizes. O porquê dessas cicatrizes, também não sei. Estão aqui como se esperava que estivessem, nessa vida para a qual não posso mais retornar inteira. Por via das dúvidas escolho fazer o seguinte: consigo ficar quieta, respiro fundo, tento relaxar todos os músculos do rosto, elimino toda e qualquer expressão e fico encarando cautelosamente o ponteiro de segundos esperando ele passar pelo centro do mostrador iluminado na sombra de uma palavra. Fixo ali o olhar. Esse tipo de... como é que pode... 
não sei se dá para captar o que se quer dizer quando se busca o inimaginável e não se deseja só ser o reflexo das coisas mesmo reconhecendo que existe sempre algo de sensacional ou até de fabuloso numa história. Porém, é mais fácil achá-la natural. Deve ser o efeito de ter entrado num sonho e saído noutro.

Tudo acontece tão rápido. Estou debruçada na borda de concreto que dá para um lago sujo e malcheiroso, estou olhando lá embaixo. Com muito cuidado, vou levantando a cabeça, não é mais um lago. É um canal. E seu derrame no mar. Compreendo que a maioria das pessoas mais ou menos normais sonha coisas curiosas, portanto sei que tudo isso é mais um sonho do que uma alucinação, porém há algo fora de propósito que não entendo. Tenho vontade de saber se vou acordar suada ou se faria tudo aquilo caso estivesse mesmo ali. A mente noutra parte vai voltando, voltando. Guardo na memória cada sensação aroma textura daquilo que comecei a viver naquela noite para querer voltar todas as noites desde então. Não quero outra vida. De qualquer forma a história do ver me deu o impulso de fazer uma tentativa de narrar essa passagem, quase mágica, e de me distrair da solidão que sentia e de ter, sem notar, ter com a escrita o impensado num tempo que já não tenho, nas noites mais deliciosamente divertidas que já tive. Alguém, se acaso me ouvisse contar, diria, com certeza, tudo não passa de invenção. Qualquer coisa imaginada. Porém somente uma outra coisa parece esquisita: como se sustentam suspensas as palavras? O que as mantém no ar? Afinal de contas ainda que soubesse ser um sonho, manter de pé algumas palavras, imóveis ou em movimento deslizando a alguns centímetros do chão, pode parecer tarefa fácil, mas não é. Costumo dizer que sonhei com um brinquedo que tinha a promessa de realizar desejos, algo sequer capaz de responder: por que os humanos não têm asas? Algo incapaz de satisfazer uma interrogação sobre o que é uma montanha-russa ou sobre o que é engraçado pra você? Acho mesmo que duas da madrugada num apartamento todo escuro, exceto pela tela do computador, seja a hora e o lugar para escrever aquilo que de uma certa e única perspectiva tinha ficado parecido com um sonho. 


\section{5}

Desde o início, e no decorrer, várias vezes eu parava para pensar na tese que estava desenvolvendo e tinha vontade de responder a esta experiência com quaseacontecimentos. Contudo nem sempre foi possível atingir a radicalidade do devirfeiticeiro de escritos que a mim se apresentaram. Ainda assim, continuei buscando.

Agora, ao despertar imersa no perfume da tinta de urucum com que tinham pintado o corpo do xamã nos corpos textuais aqui reunidos, me vejo a caminho de ter de concluir este trabalho. Escolho fechar retomando as passagens que servem de epígrafes para o texto da tese.

Convoco as epígrafes para concluir salientando a intrínseca conexão entre os modos com que Proust e Kopenawa deslocam e fazem agir a imaginação poética; bem como a disposição de ambos para habitar (em quasidade) zonas de vizinhança. A experiência de engolir a floresta, tê-la no corpo pela ação do pó de yãkoana, para devolvê-la ao mundo, é um modo de conhecimento que revigora, no campo artístico, o sonho de ser uma relação: ser "o assunto de que tratava o livro", sendo quase "uma igreja", quase "um quarteto", quase "a rivalidade entre Francisco I e Carlos V".

Fiquemos portanto com essas imagens que, passando de corpo em corpo, no confronto de mundos próprios com outros mundos, perdem sua moldura antropocêntrica e liberam o outro exilado no mesmo. Como procurei mostrar ao longo das experiências aqui postas em friçcão, trata-se de imagens que se juntam a outras imagens, abrindo-se ao inimaginável, com a possibilidade de deslocar infinitamente esse modo de viver entre quase corpos. 


\section{6 Referências bibliográficas}

ANTELO, R. Poesia e imagem. Gragoatá. v. 11, n. 20, 2009.

Maria com Marcel: Duchamp nos trópicos. Belo Horizonte: UFMG, 2010.

ARTAUD, A. O teatro e seu duplo. Tradução de Mônica Stahel e Teixeira Coelho. São Paulo: Editora Martins Fontes, 2006.

BENJAMIN, W. Pequenos trechos sobre arte. In: Rua de mão única. Obras escolhidas. v. 2. Tradução de Rubens Rodrigues Torres Filho e Carlos Martins Barbosa. São Paulo: Brasiliense, 1987.

. Magia e técnica, arte e política. Obras escolhidas. v. 1. Tradução de S. Paulo Rouanet. São Paulo: Brasiliense, 2012.

BERNHARD, T. Origem. Tradução de Sérgio Tellaroli. São Paulo: Companhia das Letras, 2006.

O imitador de vozes. Tradução de Sérgio Tellaroli. São Paulo: Companhia das Letras, 2009.

BLANCHOT, M. O espaço literário. Tradução de Álvaro Cabral. Rio de Janeiro: Rocco, 2011.

BOLLE, W. Fisiognomia da metrópole moderna: representação da história em Walter Benjamin, Edusp, 1994.

BRASIL, A. Ver por meio do invisível: O cinema como tradução xamânica. Novos estudos CEBRAP, v. 35, n. 3, p.125-146, 2016.

BRETON, A. Manifesto Surrealista. Disponível em: <http://www.culturabrasil.org/zip/breton.pdf>. Acesso em: 4 jun. 2020.

BRISSON, L. Leituras de Platão. Tradução de Sônia Maria Maciel. Porto Alegre: EDIPUCRS, 2003.

BRITTO, P. H. A poesia no momento pós-vanguardista. In.: Literatura e criatividade. Rio de Janeiro: 7Letras, 2012. 
CANÇADO. M. L. Hospício é Deus, 2015. E-book.

O sofredor do ver. 2. ed. Belo Horizonte: Autêntica, 2015.

CARNEIRO DA CUNHA, M. Pontos de vista sobre a floresta amazônica: xamanismo e tradução. Mana, v. 4, n. 1, 1998.

CASTANHEIRA, B. Perspectiva e devir em escritas contemporâneas do quase. Dissertação de Mestrado. PUC-Rio, Rio de Janeiro, 2015.

CLIFFORD, J. A experiência etnográfica: antropologia e literatura no século XX. Tradução de Patrícia Farias. Rio de Janeiro: Ed. UFRJ, 2002.

COETZEE, J. M. Elizabeth Costello: oito palestras. Tradução de José Rubens Siqueira. São Paulo: Companhia das Letras, 2004.

DELEUZE, G. Diferença e repetição. Rio de Janeiro: Graal, 1994.

Lógica do Sentido. Tradução de Luiz Roberto Salinas Fortes. 5. ed. São Paulo: Perspectiva, 2009. 2011. Crítica e Clínica. Tradução de Peter Pál Pelbart. 2. ed. São Paulo: Editora 34, Rés, s/d.

Nietzsche e a filosofia. Tradução de Antônio M. Magalhães. Porto: Editora .; PARNET, C. Diálogos. Tradução de José Gabriel Cunha. Lisboa: Relógio D’água, 2004.

.; GUATTARI, F. Percepto, afecto e conceito. In: O que é a filosofia? Tradução de Bento Prado Jr. e Alberto Alonso Muñoz. 3. ed. Rio de Janeiro: Editora 34, 2010.

Introdução: Rizoma. In: Mil platôs: capitalismo e esquizofrenia. Tradução de Ana Lúcia de Oliveira, Aurélio Guerra Neto e Célia Pinto Costa. v.1, 2. ed. São Paulo: Editora 34, 2011.

. Mil platôs: capitalismo e esquizofrenia. Tradução de Suely Rolnik. v. 4, 2. ed. Rio de Janeiro: Editora 34, 2012.

Kafka: por uma literatura menor. Tradução de Cintia Vieira da Silva. Belo Horizonte: Autêntica Editora, 2014. 
DERRIDA, J. Margens da filosofia. Tradução de Joaquim Torres Costa, António M. Magalhães. Campinas: Papirus, 1991

FALEIROS, A. Emplumando a grande castanheira. Estudos avançados, v. 26, n. 76, 2012.

GHETTI, P. S. O intruso, à beira do público e do privado. Dissertação de Mestrado. PUC-Rio, Rio de Janeiro, 2011.

HOBY, Hermione. Toni Morrison: 'I'm writing for black people... I don't have to apologise'. The Guardian. 25 abr. 2015. Disponível em: <https://www.theguardian.com/books/2015/apr/25/toni-morrison-books-interviewgod-help-the-child>. Acesso em: 16 mar. 2020.

IGLÉSIAS, M. A carta VII de Platão e as origens filosóficas do discurso autobiográfico. Tese de Doutorado. PUC-Rio, Rio de Janeiro, 2017.

KOPENAWA, D.; ALBERT, B. A queda do céu. Tradução de Beatriz PerroneMoisés. São Paulo: Companhia das Letras, 2015.

KRAUT, R. Plato. In.: The Stanford Encyclopedia of Philosophy (Fall 2017 Edition), Edward N. Zalta (ed.), 2017. Disponível em: <https://plato.stanford.edu/archives/fall2017/entries/plato/>. Acesso em: 4 jun. 2020.

LAGROU, E. A arte do outro no surrealismo e hoje. In.: Horizontes Antropológicos. 2008.

LATOUR, B. Jamais fomos modernos: ensaio de antropologia simétrica. Tradução de Carlos Irineu da Costa. Rio de Janeiro: Editora 34, 1994.

LÉVI-STRAUSS, C. A origem dos modos à mesa (Mitológicas v. 3). Tradução de Beatriz Perrone-Moisés. São Paulo: Cosac Naify, 2006.

O pensamento selvagem. Tradução de Tânia Pellegrini. 8. ed. Campinas, SP: Papirus, 2008.

LIMA, T. S. O dois e seu múltiplo: reflexões sobre o perspectivismo em uma cosmologia Tupi. Mana, Rio de Janeiro, v. 2, n. 2, p. 21-47, 1996.

O que é um corpo. Religião \& Sociedade, v. 22, n. 1, 2002.

LIMA, I. S. A voz e a cruz de Rita: africanas e comunicação na ordem escravista. In.: Revista Brasileira de História, v. 38, n. 79, 2018. 
LINS, D. Antonin Artaud: o artesão do corpo sem órgãos. In.: A lógica do ato psicanalítico, 1999.

LISPECTOR, C. A paixão segundo G. H. Rio de Janeiro: Francisco Alves, 1990.

MARTINS, H. Sobre a estabilidade do significado em Wittgenstein. Veredas Revista de Estudos Linguísticos, v. 4, n. 2, 2000.

. Poeira de verbo. In: Literatura e criatividade. Rio de Janeiro: 7Letras, 2012.

. Tradução e perspectivismo. Revista Letras, v. 85, n. 1, 2012.

. Dizer e mostrar como performativos. Documentação de Estudos em Linguística Teórica e Aplicada. v. 32, 2016.

- Para levar a sério a mitologia alheia: linguagem, crítica e alteridade em Wittgenstein. In: FERREIRA, R. R.; RAJAGOPALAN, K. (Orgs.). Um mapa da crítica nos estudos da linguagem e do discurso. Campinas, SP: Pontes Editores, 2016.

. Resta saber se o não-pensamento contamina o pensamento: citação e invenção em Adeus à Linguagem de Jean-Luc Godard. Cadernos de Literatura Comparada, n. 41, p. 171-190, 2019.

MEDEIROS, S. (Org.). Makunaíma e Jurupari: Cosmogonias Ameríndias. São Paulo: Perspectiva, 2002.

MENDES, M. Poesia completa e prosa. Rio de Janeiro: Nova Aguilar, 1994.

MILlER, H.; FRAENKEL, M. The Michael Fraenkel - Henry Miller correspondence called Hamlet. Tradução inédita de Helena Martins e Marcia Schuback. London: Carrefour Press, 1939.

MOISÉS, M. Dicionário de Termos Literários. São Paulo: Cultrix, 2004.

MORRISON, T. Amada. Tradução de José Rubens Siqueira. São Paulo: Companhia das Letras, 2007.

. Entrevista a Hermione Hoby para o Jornal The Guardian, 25 de abril de 2015. Disponível em: <https://www.theguardian.com/books/2015/apr/25/toni-morrisonbooks-interview-god-help-the-child>. 
NANCY, J.-L. El sentido del mundo. Tradução de Jorge Manuel Casas. Buenos Aires: La Marca, 2003.

L'Intrus. Paris: Galilée, 2010.

Fazer, a poesia. In.: ALEA. Tradução de Mauricio Cardozo. v. 15, n. 2, 2013.

NIETZSCHE, F. Sobre verdade e mentira no sentido extra moral. In.: Obras incompletas. Tradução: R. R. Torres Filho. São Paulo: Abril Cultural, 1978.

. Humano, demasiado humano: um livro para espíritos livres. Tradução de Paulo César de Souza. São Paulo: Companhia das Letras, 2005.

A vontade de poder. Tradução de Marcos Sinesio Pereira Fernandes e Francisco José Dias de Moraes. Rio de Janeiro: Contraponto, 2008.

\section{1.}

A gaia ciência. Tradução de Paulo César de Souza. São Paulo: Cia das Letras,

NODARI, Alexandre. Como (verbete). Sopro. n. 78, 2012.

$38,2015$.

A literatura como antropologia especulativa. Revista da ANPOLL, v. 1, n.

. Quase-evento: sobre a estoricidade da experiência literária. eLyra: Revista da Rede Internacional Lyracompoetics, n. 10, 2018.

PEREIRA, E. A. Qvasi: segundo caderno. São Paulo: Editora 34, 2017.

Literafro Entrevista. TV UFMG. 2018. Disponível em: <https://www.youtube.com/watch?v=f9PXoq2G3Uo>. Acesso em: 4 jun. 2020.

PERLOFF, M. 21st-Century Modernism: The "New" Poetics. Oxford: Blackwell Publishers, 2002.

A escada de Wittgenstein: a linguagem poética e o estranhamento do cotidiano. Tradução de Elizabeth Rocha Leite e Aurora Fornoni Bernardini. São Paulo: Editora da USP, 2008.

PLATÃO. República. Tradução de Maria Helena da Rocha Pereira. Lisboa: Calouste Gulbenkian, 1996. 
PLATÃO. Carta VII. Tradução de José Trindade Santos e Juvino Maia Jr. Rio de Janeiro: Loyola/PUC-Rio, 2008.

Fédon. Tradução de Carlos Alberto Nunes. Belém: UFPA, 2011.

Fedro. Tradução de Carlos Alberto Nunes. Belém: EDUFPA, 2011.

RIBEIRO, L. N. T. À escuta da língua inarticulada em Guimarães Rosa. Tese de Doutorado. PUC-Rio, Rio de Janeiro, 2018.

RISÉRIO, A. Palavras canibais. Revista USP, n. 13, p. 23-46, 1992.

Textos e tribos: poéticas extraocidentais nos trópicos brasileiros. Rio de Janeiro: Imago, 1993.

RODGERS, David. A soma anômala: a questão do suplemento no xamanismo e menstruação Ikpeng. Mana. v. 8, n. 2, p. 91-125, 2002.

The filter trap: Swarms, anomalies, and the quasi-topology of Ikpeng shamanism. HAU: Journal of Ethnographic Theory. v. 3, n. 3, 2013.

RORTY, R. M. Objectivity, relativism, and truth: philosophical papers. Cambridge University Press, 1991.

ROSA, J. G. Diálogo com Guimarães Rosa (Günter Lorenz). Ficção Completa. v. 1. Rio de Janeiro: Nova Aguilar, 1994.

ROTHIER, M. A força investigativa da ficção. In: Literatura e criatividade. Rio de Janeiro: 7Letras, 2012.

O narrador contemporâneo e o arcaico. In: Cenários contemporâneos da

escrita. Rio de Janeiro: SetteLetras/Faperj, 2014.

SAER, J. J. O conceito de ficção. FronteiraZ. Revista do Programa de Estudos PósGraduados em Literatura e Crítica Literária. Tradução de Luís Eduardo Wexell. n. 9, 2012.

SANTOS, R. C. Uma vida de artista. In: Conferência de encerramento de Atividades Acadêmicas promovidas pelo corpo discente do Programa Pós-Graduação em Literatura, Cultura e Contemporaneidade do Departamento de Letras da PUCRio. Rio de Janeiro: 2012. Disponível em: <https://www.youtube.com/ watch?v=h41ZsUobYhM\&t=899s $>$. Acesso em: 4 jun. 2020. 
SMITH, B. Poetic Closure: A Study of How Poems End. Chicago: University of Chicago Press, 1968.

SOBRINHO, N. C. M. Friedrich Nietzsche: perspectivismo e superação da metafísica. Revista Comum, v. 9, n. 22, Rio de Janeiro, 2004.

SOUZA, S. M. C. A predicação da língua geral de mina. PAPIA-Revista Brasileira de Estudos do Contato Linguístico, v. 13, n. 1, 2010.

SZTUTMAN, R. (Org.). Encontros: Eduardo Viveiros de Castro. Rio de Janeiro: Azougue, 2008.

TARDE, G. Monadologia e sociologia. In: Monadologia e sociologia: e outros ensaios. Tradução de Paulo Neves. São Paulo: Editora Unesp, 2018.

VIVEIROS DE CASTRO, E. Araweté: Os Deuses Canibais. Rio de Janeiro: Zahar / Anpocs, 1986.

1996.

Os pronomes cosmológicos e o perspectivismo ameríndio. Mana, v. 2, n. 2,

Cosmological deixis and Amerindian perspectivism. Journal of the Royal Anthropological Institute, 1998.

A inconstância da alma selvagem e outros ensaios de antropologia. São Paulo: Cosac Naify, 2002.

O nativo relativo. Mana, v. 8, n. 1, 2002.

Perspectival anthropology and the method of controlled equivocation. Tipití: Journal of the Society for the Anthropology of Lowland South America, v. 2, n. 1, 2004.

A Filosofia Canibal. Folha de São Paulo. São Paulo, 21 ago. 2005. Disponível em: <https://www1.folha.uol.com.br/fsp/mais/fs2108200509.htm>. Acesso em: 4 jun. 2020.

A floresta de cristal: notas sobre a ontologia dos espíritos amazônicos. Cadernos de campo: revista dos alunos de pós-graduação em antropologia social da USP, São Paulo, n. 14/15, 2006.

Filiação intensiva e aliança demoníaca. In.: Novos estudos. CEBRAP, 2007. 
VIVEIROS DE CASTRO, E. A morte como quase acontecimento. In: Café Filosófico. TV Cultura/CPFL: 2009. Disponível em: 〈http://www.cpflcultura.com.br >. Acesso em: 4 jun. 2020.

The Nazis and the Amazonians, but then again, Zeno. In: Symposium on Comparative Relativism. Copenhagen: IT University, September. 2009.

2011.

. O medo dos outros. Revista de Antropologia da USP. São Paulo, n. 2, v. 54,

A força de um inferno: Rosa e Clarice nas paragens da diferOnça. Palestra em abril de 2013. Disponível em: <https://laboratoriodesensibilidades. wordpress.com>. Acesso em: 4 jun. 2020.

Metafísicas canibais. São Paulo: Cosac Naif, 2015.

WHITE, S. F. An interview with Edimilson de Almeida Pereira. Callaloo, v. 19, n. 1, winter, 1996. Disponível em: <https://www.jstor.org/stable/pdf/3299318.pdf?refreqid =excelsior\%3Acdfd4df1c571cdcf48edd90fc85591b2>. Acesso em: 16 mar. 2020.

WITTGENSTEIN, L. Da certeza. Lisboa: Edições 70, 1990.

Cultura e valor. Lisboa: Edições 70, 1996.

Investigações filosóficas. Bragança Paulista: Editora Universitária São Francisco: Petrópolis: Vozes, 2008.

ZOURABICHVILI, F. Deleuze: uma filosofia do acontecimento. Tradução de Luiz B. L. Orlandi. São Paulo: Editora 34, 2016. 